
MUSEUM OF VICTORIA

|

"inimin

36698 



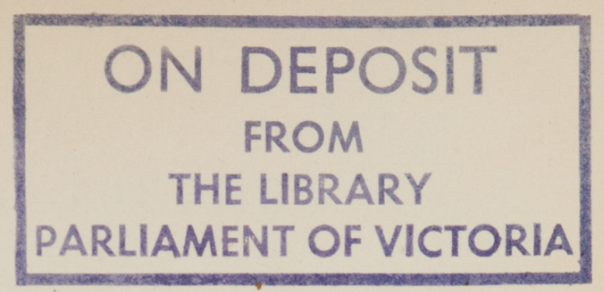


$4 r$ 


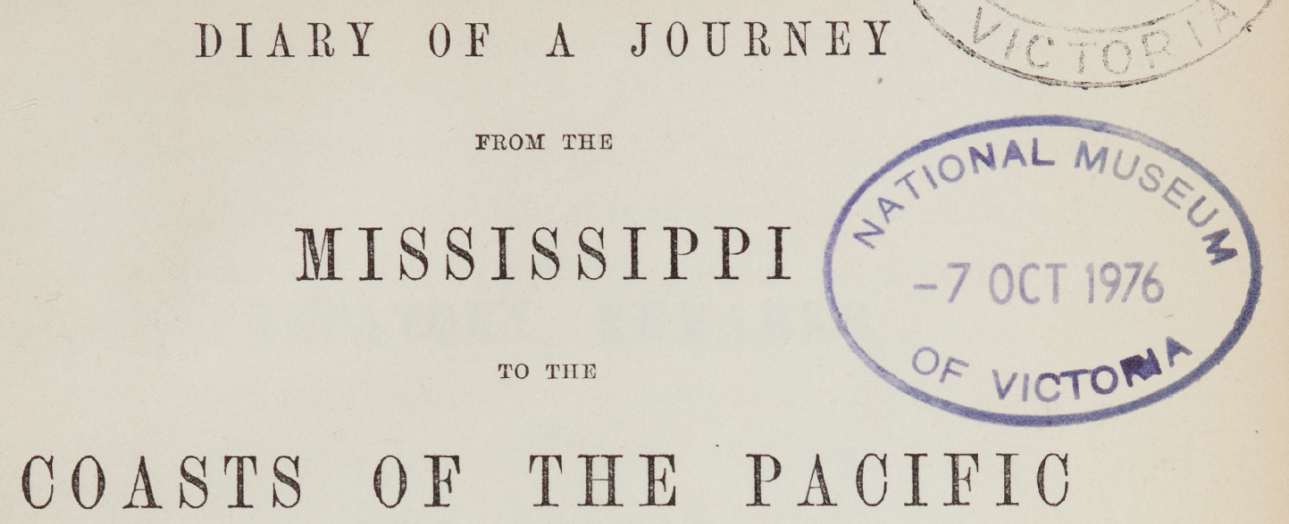

WITH A UNITED STATES GOVERNMENT EXPEDITION.

\section{BY BALDWIN MÖLLHAUSEN}

TOPOGRAPHICAL DRAUGHTSMAN AND NATURALIST TO THE EXPEDITION.

WITH AN INTRODUCTION BY ALEXANDER VON HUMBOLDT AND

ILLUSTRATIONS IN CHROMO-LITHOGRAPHY.

TRANSLATED BY MRS. PERCY SINNETT.

IN TWO VOLUMES.

VOL. I.

LONDON

LONGMAN, BROWN, GREEN, LONGMANS, \& ROBERTS. 
$a^{7} 7^{3}{ }^{3}$ 


\title{
PREFATORY REMARKS
}

\author{
THE A UTHOR。
}

ON my return from an excursion to the United States of North America, during which I had spent a considerable time among the Indians on the Nebrasca or Platte River, I remained four months in Berlin, with the view of perfecting myself in some branches of artistic study; but my determination to return to the wilderness which had made so powerful an impression on my mind, continued unshaken; and after an eighteen days' passage from the mouth of the Elbe to New York, I landed there on the 3rd of May 1853, and proceeded at once to Washington to deliver despatches entrusted to me by the American embassy in Berlin. I was provided with recommendations, written under the influence of the kindest feelings, and with a confidence inspired by my previous journeys in the prairies of the Far West. These introductions procured for me warm sympathy and the most disinterested friendship in the highest circles, and 
promised to be of considerable service to me in the execution of my plans for visiting the countries on the western slope of the Rocky Mountains.

I could not have arrived in Washington at a more favourable moment, the government of the United States being just on the point of despatching three expeditions along different parallels of latitude, to seek out the best line for a railway to California.

The first of these expeditions, commanded by Governor Stevens, was directed to move westward between the 47 th and 49th parallels N. L., to cross the Rocky Mountains near the source of the Missouri and the Columbia Rivers, and follow the valleys of these two streams, deviating as little as possible, so as to ascertain precisely what facilities they would offer for the construction of the proposed railway.

The second, under Capt. Gunnison, was to proceed along the 38th parallel, on a line marking the nearest route between San Francisco and San Louis and the navigable waters of the Mississippi, and in its prolongation dividing the territory of the United States into two nearly equal parts.

Finally, the third, headed by Lieut. Whipple, was to follow the 35 th parallel N. L., in order that in the poorly watered prairies to the east, and the desolate wastes to the west of the Rocky Mountains, they might take advantage of the tributary streams of the Mississippi, the Rio Grande, and the great Colorado of the west.

The two first named expeditions had already started, 
but the last was still engaged with preparations; and as the party of scientific men who were to attend to that department of the expedition was not yet complete, I applied, in accordance with the advice of my friends, to Lieut. Whipple, to be received among them, and in a few days had the following answer.

"Mr. Möllhausen,

“Washington, May 10th, 1853.

"You are hereby appointed to accompany, as topographer or draughtsman, the expedition under my command; you will therefore proceed to Fort Smith on the Arkansas, in the State of Arkansas, and there await further orders. At Fort Napoleon, at the mouth of the Arkansas, your duties will begin, and you will thence keep an official journal, making such drawings and memoranda as may appear to you of value or interest for the expedition to which you belong.

\section{"A. W. Whipple,}

"Commander of the Southern Expedition for determining the line of Railway to the Pacific Ocean."

My preparations were soon complete; I only awaited a few more instructions from the Smithsonian Institution respecting the Natural History Collection, which department had also been entrusted to me, and was soon flying along on the iron road across the Alleghany Mountains, towards the State of Ohio. At Cincinnati, 
the capital of that state, I embarked on board the steamer "Norma," proceeding down the Ohio River, and reached its confluence with the Mississippi on the 9th of June. After a brief stay at the town of Cairo, situated at this point, the steamer continued her journey down the Mississippi, and on the 12th of June I found myself at my immediate destination - the mouth of the Arkansas. 


\section{PREFACE}

BY

\section{ALEXANDER VON HUMBOLDT.}

ReLations of reciprocal good will, and a certain similarity of endeavour in important and serious undertakings, could alone have induced me to overcome the objection I have always felt-perhaps without sufficient reason - to introductory prefaces by any other hand but that of the author.

During the whole course of my life I have written such prefaces only four times; namely, for the French translation of the Voyage to the North Cape of our great geologist, Leopold von Buch; for the English narrative of Sir Robert Schomburgh's dangerous enterprise of five years' duration, undertaken to connect the coasts of Guiana, at Essequibo, astronomically with the eastern point of the Upper Orinoco, which I had reached from the west ; thirdly, for the original edition of the complete works of my ever-memorable friend, François Arago; and lastly, for the Travels in the 
East Indies and Thibet of the late amiable and lamented Prince Waldemar of Prussia.

In the present instance I have voluntarily undertaken the task, from esteem for the untiring energy and activity manifested by the author in an important undertaking, as well as for the modest integrity of his vigorous and honourable character, and the remarkable artistic talent which he has developed, almost wholly by the study of Nature.

The present volumes make no pretension to the character of a scientific work, although they contain much valuable information on the physical geography of the regions investigated - sometimes from the author's own observation, sometimes communicated by other members of the party specially skilled in those departments. Mr. Möllhausen was appointed to accompany, as topographer and draughtsman, the Expedition sent by the Government of the United States to determine the direction of a line of railroad from the coasts of the Pacific; and he here offers the diary which he kept as a kind of commentary on his pictorial sketches of the country and the people, and in which he has reflected. back, with the freshness with which they were received, his impressions of life and Nature.

When a traveller's descriptions are the result of accurate and conscientious observation, and especially when they concern the condition of natives standing at various grades of uncivilised life, they must always interest the student of humanity. A melancholy ex- 
perience has taught us that, in almost all climates, the vicinity of European or North American settlers has always tended to the destruction of the uncivilised races. Crowded together within narrow limits, and where the near contact affords opportunity for plunder, often sinking into a lower moral state than they occupied before, they gradually waste away in unequal conflicts. If, at the commencement of the Empire of the Incas of Peru, in the Cordilleras of Quito, and the elevated plains of New Granada (the ancient Cundinamarca), and in the Mexican Anahuac, south of the 28th parallel, the ancient population has maintained itself, and at some points even considerably increased, the cause must be sought in the fact that, many hundred years before the Spanish conquest, the population consisted of peaceful agricultural tribes. The report concerning the ethnography, and of the physical and moral condition of the scarce, coppercoloured, or rather brown-red, natives of the regions between the Missouri and the Rocky Mountains, is interesting in a twofold point of view, either with reference to generalisations concerning the sometimes progressive and sometimes stationary character of civilisation, or to particular local and historical circumstances. In general views of the manifold grades of intelligence manifested by those whom we so vaguely, and often so improperly, denominate savages, the Indios bravos, the imagination is carried beyond the narrow limits of the present to a mysterious past, in 
which the greater part of the human race - of those who have now attained to so high a point of civilisation, art, and science-lived in the same rude condition. How often have such thoughts occurred to me during a river navigation of fifteen hundred miles in the wildernesses of the Orinoco, south of the cataracts of the Atures, on the Atabapo-Cassiquiare and Rio Negro. But even in the savage state you are struck occasionally by signs of spontaneously awakening intellectual power in the knowledge of several languages, by which the intercourse between neighbouring tribes is so much facilitated - in the anticipation of a future existence of joy or sorrow, and in traditions that boldly rise to the origin of the human race, and its abode.

The hordes which occupy the country between New Mexico and the river Gila specially attract our attention, because they are scattered about the line of march along which, in the period from the sixth to the twelfth centuries, the various nations known as Tolteks, Chichimekis, Nahuatlakes, and Aztecs proceeded when they traversed and partly peopled southern tropical Mexico. Memorials remain of the architectural and industrial skill of these nations, who had evidently attained to a high degree of culture. The various stations or abiding places of the Aztecs on the river Gila, and at several points south-south-east of it, can still be pointed out by means of historical paintings and ancient traditions. They are laid down in my Mexican atlas. And the large, many-storied, family houses (casas grandes) 
seen in 1846 by the engineer, Lieutenant W. Abert, and subsequently by Möllhausen, - houses which are entered by means of ladders, drawn up at night, _offer analogies to the mode of building in use among some of those tribes.

The gigantic sculptures and religious and historical paintings left by the Tolteks or Aztecs, who built pyramids, and kept the record of cycles of years, show a striking agreement in their representations of the human form and face, the physiognomical character of which, especially in the structure of the forehead, and of the very large and prominent aquiline nose, differs much from that of the present many millions of agricultural native inhabitants of Mexico, Guatemala, and Nicaragua; and the solution of the problem discussed by the acute Catlin, whether these forms, and the physiognomical structure can still be found among the northern tribes, - not merely in individuals, but races, and where,-becomes of great ethnographical importance.

In the case of the American migration of nations from north to south (as in that of the Asiatic nations from east to west), to which the attack of the Huingnu on the fair Yueti and Usïn gave the earliest impulse, might not single tribes have remained behind northward of the Gila, as others in the Caucasus of the Pontic isthmus. All the conjectures connected with the bold hypothesis concerning the sources of a certain amount of civilisation evident in the original seats of the wan- 
dering nations (Huehuetlapallan, Aztlan, and Quivira), have hitherto fallen into the abyss of historic myths. Want of faith in the possibility of finding a satisfactory solution of the problem, in the absence of more sufficient materials for judgment, must, nevertheless, not be allowed to lessen our diligence, or set limits to our inquiries. The question concerning the remains of these wandering nations of the north will find much satisfaction in Catlin's oil pictures (preserved in the Berlin Museum), as well as in Möllhausen's drawings. It has also given rise to a valuable work in the philological field, in which the traces of the Aztec idiom (Nahuatl) are followed along the western side of North America. Professor Buschmann, my talented friend of many years' standing, has therein confirmed some opinions that I expressed on the subject half a century ago; and in works undertaken in conjunction with my brother, Wilhelm von Humboldt, has turned his profound knowledge of the ancient Aztec language to historical account.

In addition to the historical and ethnological interest connected with a part of the earth so little known, and the exact description of which is the object of the following pages, its political importance, with relation to the commerce of the world and its cultivation, which must stand in immediate connection with that commerce, becomes a no less suggestive subject of reflection. The rich Atlantic States on the Ohio and Mississippi find themselves compelled, by the course of events, to 
seek the best route to the newly acquired countries on the Pacific coast, which have now been received into the mighty American Union. These countries are richer than the sea-board lying opposite to Europe in safe and beautiful harbours, in timber for ship building, and in the mineral productions most in demand. This new territory, so long under the strict, though peaceful, rule of the monks, and engaged only in the productive chase of the sea-otter, is now, with all its physical advantages, in the hands of a restlessly active, enterprising and intelligent population, destined to play an important part in the commerce with China and Japan, as well as in the slowly rising trade of East Siberia.

At the time of the second discovery of America by Columbus, there were found along the western part of the new continent, from the Mexican Anahuac to Chili, regular, social, and political institutions, widely diffused a common form of religious worship, monumental sculptures, great architectural works, temples, pyramids, palaces, and fortifications. The far more extensive and flatter eastern region, though covered with a perfect net-work of rivers, was inhabited only by savage tribes, isolated, and scarcely capable of any co-operation even for a warlike undertaking, and maintaining themselves only by hunting and fishing. This singular contrast between civilisation and uncivilisation, thus geographically marked out, began to disappear when the great oceanic valley was crossed from the most VOL I. 
northern and the most southern part of Europe, at periods separated by an interval of five hundred years.

The first Scandinavian island settlement, originated by Leif, the son of Erik the Red, was feeble and transitory, and in a moral sense fruitless; it remained without effect on the condition of the natives, although the American coasts of the frigid and temperate zones, from the seventy-third degree (namely, from the small group of "Women's Islands" in West Greenland) to the forty-first, were visited by bold Christian navigators. It was not till the second discovery of America by Christopher Columbus, a discovery that took place within the torrid zone, that the one half of the earth began to be really revealed to the other, and the old promise of the astronomer and physician Toscanellibuscar el levante por el poniente, to find the golden East, by sailing to the west - became fulfilled. If we go back in imagination to those ages of the world in which the civilised nations who dwell round the basin of the Mediterranean saw its gates opened to them by the founding of Tartessus, and the important, though erroneous, voyage of Colaus of Samos, we shall recognise the same impulse to move from east to west which carried the Atlantic navigators across the vast ocean. The historical events, in which a great part of the human race appears animated by a similar tendency, lead to great results, slowly, indeed, and gradually, but so much the more certainly, developing themselves according to eternal laws, like those which reign in organic nature. 
Although the Pacific was first seen seven years after the death of Columbus, by Vasco Nuñez de Balboa, from the summit of the Sierra de Quarequa, on the Isthmus of Panama, and a few days afterwards navigated in a canoe by Alonzo Martin de Don Benito, Columbus had obtained precise information of its existence eleven years before, in the year 1502, during his fourth voyage, the one in which he most displayed the vigour of his genius. He gained the information at Puerto de Retrete, on the east coast of Veragua, and he points out, in his carta rarissima of the 7th of July, 1503, in the letter wherein he so poetically describes his magnificent dreams in the clearest manner, the two opposite lying oceans, or, as his son says in the biography of his father, the contraction (estrecho) of the continent at that part. The ocean, whose existence had been revealed to him by the natives of the country, must lead, he thought, to the gold Chersonesus of Ptolemy, and the East Asiatic land of Spices; whither, some day, North American fleets, built in San Francisco, will sail under the guidance of the chronometer. The distance, in a straight line, from the Atlantic coast to that of San Francisco, in California, is about 2200 miles, and there is a kind of pleasure in looking back to the small beginnings of our knowledge of the Pacific, to all that even Columbus could know of it on his death-bed, at a time when such gigantic projects are entertained of railways and oceanic canals through the Narpi and Cupica; through the Atrato and the Rio Truando; the 
Huasacualco and the Chimalapa; through the Rio San Juan and Lake Nicaragua. That great Columbus, half forgotten, as I have elsewhere shown, even by his contemporaries, died (at Valladolid, 20th of May, 1506) in the firm belief, shared also by Amerigo Vespucci until his death at Seville (Feb. 22nd, 1522), that they had discovered only the coasts of the continent of Asia, and no new part of the world. Columbus considered the sea that washes the western part of Veragua so near the gold Chersonesus, that he compares the relative positions of the province of Ciguare, in West Veragua, and Puerto Retrete (Puerto Escrivanos), to those of Venice and Pisa, or from Tortosa, at the mouth of the Ebro, to Fuenterabia on the Bidassoa, in Biscay; and he reckoned from Ciguare to the Ganges (Gangues) only nine days' journey. It appears to me worthy of consideration, too, that at the present day the gold fields (las minas de la Aurea), which the carta ravissima of Columbus points out as lying in the most eastern part of Asia, are really to be found on the western side of the new continent.

To give a descriptive survey of the contrast between the former and the present time, and the great benefit which an intelligent investigation of the terra incognita of the far West, within the territory of the United States, will afford to our geographical knowledge for many years to come, has been the chief purpose of this preface. It remains for me, in conclusion, to fulfil the agreeable duty of reminding the reader that the author 
of the following narrative of a Journey from the Mississippi and Arkansas to the shores of the Pacific, had the advantage, in a former journey to the Nebraska river, of familiarising himself with the life of the Indian tribes by a long stay among them. He is the son of a Prussian artillery officer, and at twenty-four years of age left the service and his country, with the most honourable testimonials from his superior officers, to proceed to the western part of the United States. He was independent and alone, but irresistibly urged onwards, as is most frequently the case with active and energetic characters, by a thirst for the aspect of wild, free nature, and vast untrodden regions. When near the banks of the Mississippi he happened to hear of the proposed grand and promising scientific Expedition of H. R. H. Duke Paul William of Wurtemberg to the Rocky Mountains. He asked permission to join it, which was accorded in the most gratifying manner, and the Expedition proceeded without accident as far as Fort Laramie, on the Flat River, but there the unpracticable character of the ground, a terrible and general affection of the eyes from a fall of snow, the repeated attacks of the Indians, and the deaths of a great number of horses, indispensable for the journey, compelled the duke for the time to give up his intention. Having been separated from the party, M. Möllhausen joined a passing band of Ottoe Indians, who provided him with a horse; after which he turned 
northwards to Bellevue, at that time the seat of an agency and depôt of the fur company. After a residence of three months among the Omahas, during which he was an active associate of their hunting parties, he embarked on board a steamer going down the Mississippi, and had the pleasure of again meeting Duke Paul of Wurtemberg, accompanying him in several excursions, and assisting him in adding to his important geological collection. In 1852 he embarked at New Orleans for Europe, having been commissioned by M. Angelrodt, the estimable Prussian consul at St. Louis, at the mouth of the Missouri, to take charge of a number of interesting animals, destined for the Berlin Zoological Gardens.

With increased knowledge, and improved artistic culture, although with very limited resources, M. Möllhausen had taken the bold resolution of making another journey to the West of the United States, and through the intervention of my old and valued friend, Professor Lichtenstein, I became acquainted with the enterprising young traveller. Although now, perhaps, the oldest traveller of the age, I remembered too well the enthusiastic feelings of my early life not to be interested in a young man of such congenial tastes, and who had been so warmly recommended to me; and the kindness of a monarch, who has always so gladly extended his protection to rising talent, permitted M. Möllhausen to lay before him in person his remarkably clear and accurate 
Sketches of Indian Life. The increasing favour with which my labours and exertions have been regarded in the United States, and the generous sacrifices made by many of the particular governments there for the encouragement of intellectual progress, especially in all departments of astronomical and geographical science, and of natural history, led me to hope that recommendations from me, joined to those of my dear friend the Prussian ambassador, M. von Gerolt, would, on his return to the United States, have some weight with the authorities and with the admirable Smithsonian institution; and my hopes were speedily fulfilled. M. Möllhausen has himself, in the commencement of his narrative, mentioned his appointment as topographical draughtsman* in the very completely equipped Expedition under Lieutenant Whipple.

Notwithstanding the fatigue inseparable from a land journey of eleven months' duration, the traveller several times sent papers, two of which were of remarkable interest, to the Geographical Society of Berlin. One related to the manners and physical conformation of some little known Indian tribes on the great Colorado and in the neighbouring mountains - Mohaves, Cutchanas, and Cosninos; the other to the so-called petrified forest, between the "Old Town" (Pueblo de Zuñi), and the Little Colorado. This remarkable phenomenon,

* M. Möllhausen frequently speaks of himself as the "German Naturalist" of the Expedition, and appears to have acted also in that capacity. 
in which coniferce were found united with tree ferns, was also examined by M. Marcou, the geologist of the Expedition, now professor at the Federal Polytechnic School of Zurich, and it has been described in his extremely instructive work, entitled "General Orography of Canada and the United States." The following narrative of travel has been enriched by some scientific notes from the learned works of Professor Marcou, now printed.

The purpose of the Expedition under Lieutenant Whipple was happily attained on the 23rd of March, 1854 , by its arrival on the Pacific coast, at the sea-port of San Pedro, to the north of the Californian mission of San Diego. The return was by a rapid journey across the Isthmus of Panama to New York; and after an absence of a year and five months, M. Möllhausen returned to Berlin with his collections, and a great number of interesting pictorial studies from nature in the Far West, which met with the most encouraging approval from his sovereign. His Majesty has since been graciously pleased to take the young traveller into his own service, by appointing him to be the keeper of the libraries in the castles of Potsdam and the environs.

His fresh and animated descriptions of wild nature in all the manifold variety of her forms, of the uncivilised state of the native tribes, and of the habits of various species of animals, evince a keen sensibility that naturally finds adequate expression in language. 
What Baldwin Möllhausen has learned of Nature through so many vicissitudes and privations, though with many compensatory pleasures, has not been lost to his intellectual culture; as Schiller says, with beautiful simplicity, "Man himself grows with his aims."

Berlin. 



\section{CONTENTS}

OF

\section{THE FIRST VOLUME.}

\section{CHAP'TER I.}

On the Mississippi. - Fort Napoleon. - Shores of the Arkansas. Little Rock. - Van Buren . . . . . . Page 1

CHAP. II.

Fort Smith. - Fitting out of the Expedition. - Camp Life at Fort Smith._Bill Spaniard. - Taming the Mules . . 11

\section{CHAP. III.}

The Lands on the River Poteau. - The Indians. - Their Settlements. - Passage of the Poteau. - The Storm. - Fort Koffee - 23

\section{CHAP. IV.}

Sculleville. - The Choctaw Agency. - Traditions of the Choctaws. - Choctaw Council. - Sans-Bois Creek. - Pine Grove. - Ball Playing among the Choctaws . . . 33 
CHAP. V.

Fraser, the Indian Smith. - Sans-Bois Creek. - The Four 'Trappers. - Dr. Bigelow and his Adventure.-A Trip on the Canadian

Page 50

\section{CHAP. VI.}

Gaines Creek. - The Creek Indians. - The Cherokee Indians. The Shawnees. - Ten-squa-ta-way, the Shawnee Prophet. Shawnee Town. - Fort Edwards. - The Quappa Indians. - Topofkee Creek — and Mustang Creek. - Johnson the Scout. - The Evening Hunt. - The Four 'Trappers (continuation) • 67

\section{CHAP. VII.}

Old Fort Arbuckle. - The Delawares. - Si-ki-to-ma-ker, the Delaware Chief. - The Abode of the "Black Beaver." - Vincenti. The Black Beaver's Recollections. - Walnut Creek. - Prairie Fires .

\section{CHAP. VIII.}

The Waekow Indians. - The Witchitas. - The Kechies. - An Adventure on the Nebraska. - The Buffalo Hunt. - The Buffalo. Indian Buffalo Hunts. - The Cross Timbers. - Game on Deer Creek._Encampment on Deer Creek . . . 114

\section{CHAP. IX.}

The Adventure on the Nebraska (continued). - The Mirage. Natural Mounds and Rock Mary. - The Gypsum Region. - The Gypsum Cave. - The Doctor's Bear Hunt on the Gila. - The Great Prairie 


\section{CHAP. X.}

The Antelope Hills. - The Prairie Dog. - Adventure on the Nebraska (continued). - Grapes. - The Comanche Indians. - Wild Horses, or Mustangs. - Accident to the German Naturalist - Page 165

\section{CHAP. XI.}

The Dry River and its Peculiarities. - The great Cotton-wood Tree. - Mode of 'Travelling in the Steppe. - The Naturalist's Account of his Stay among the Ottoe Indians. - Arrival of the Expedition among the Kioway Indians.-Conversation with them.--Passage of the Canadian. - Doctor Bigelow's Escape from the Quicksand

\section{CHAP. XII.}

Further Progress of the Expedition up the Canadian. - Shady Creek. - Summer Dwellings and Medicine Tent of the Comanche Indians. -A Fandango in the Steppe. - Pueblo Indians. - Opuntia Arborescens. - The Relations between the Mexicans and Indians. Inez Gonzales. - Beautiful View Creek.-El Llano Estacado

\section{CHAP. XIII.}

Continuation of the Naturalist's Story. - Encampment Creek. Journey across the Llano Estacado. - Arrival at Rocky Dell Creek. - Indian Paintings . • . • • 242

\section{CHAP. XIV.}

Western Boundary of Texas. - Cerro de Tucumcari. - The Robbers of New Mexico._Tucumcari Creek._Pyramid Rock • 267 


\section{CHAP. XV.}

Continuation of the Naturalist's Narrative. - Camp of the Laguna Colorado. - The Gallinas. - Flocks of New Mexico. - Arrival of the Expedition at Pecos, and Anton Chico . Page 287

\section{CHAP. XVI.}

Anton Chico. - A Fandango. - Departure - Cañon Blanco. - The Water Spout. - Galisteo. - Fitzwater. - Volcanoes in New Mexico. - Cañon Boca

\section{CHAP. XVII.}

The Valley of the Rio Grande del Norte. - Saint Domingo, and the Pueblo Indians. - Their Traditions. - Departure from Saint Domingo. - Arrival in Albuquerque . . . . 331 


\title{
LIST OF ILLUSTRATIONS
}

\author{
IN VoL. I.
}

\section{COLOURED LITHOGRAPHS.}

Waki-ta-mo-ne and his Troop of Hunters. - Ottoe Warriors Frontispiece. Map of the Author's Route . . . . To face page 1

Sandstone Formation in the Prairie north-west of Texas $\quad$ " 136

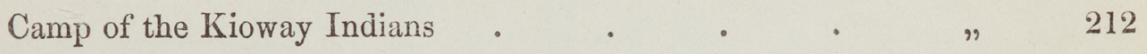

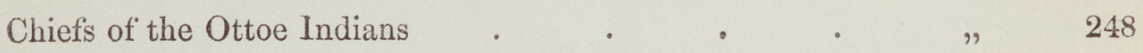

Sandstone Formation near Pueblo de Santo Domingo . $\quad$ " 276

Church of the Pueblo de Santo Domingo . . " „ 336

WOODCUT.

Geological Section of the Llano Estacado _ . " " 350 




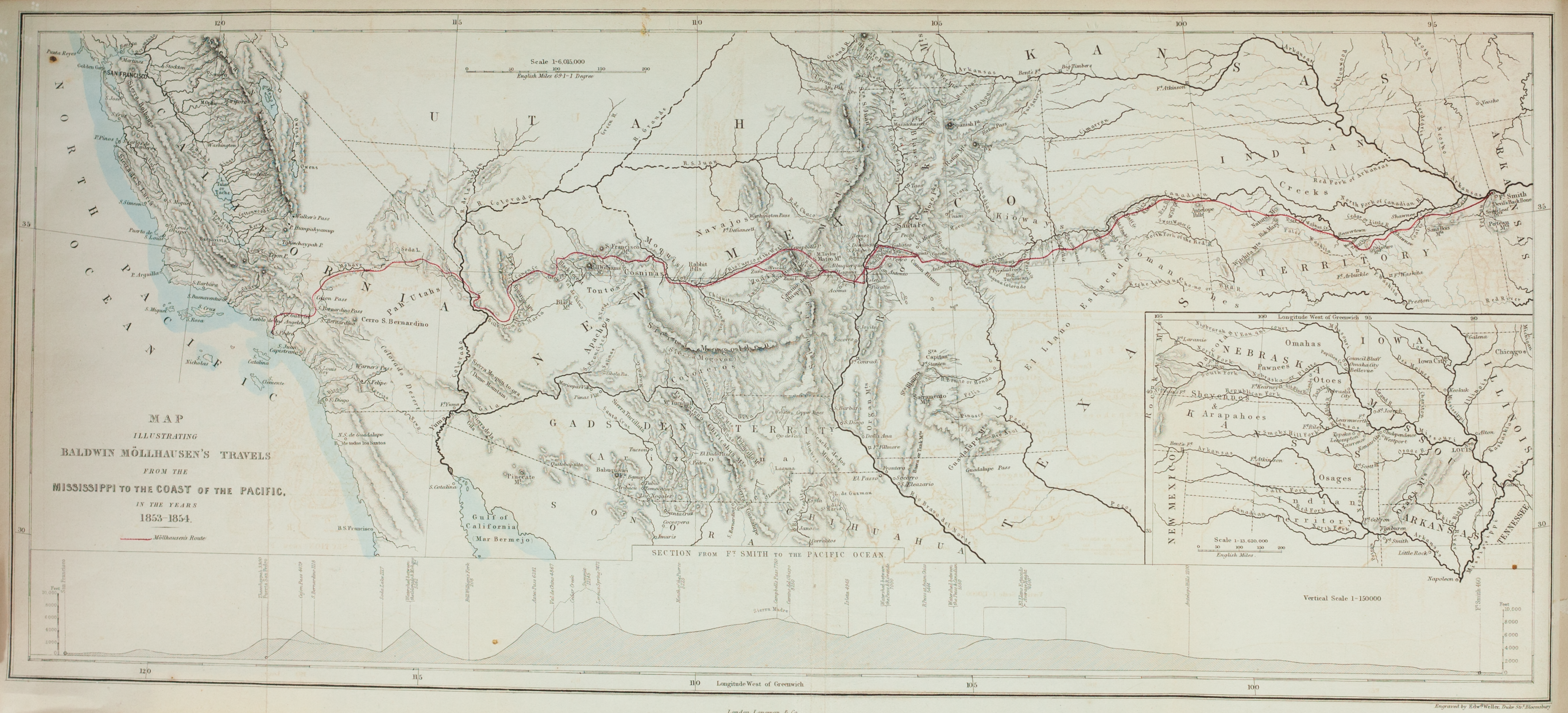




\section{J 0 UR NEY}

FROM

\section{THE MISSISSIPPI TO THE PACIFIC.}

\section{CHAPTER I.}

ON THE MISSISSIPPI.- FORT NAPOLEON. - SHORES OF THE ARKANSAS. LITTLE ROCK. - VAN BUREN.

There are few situations in which a traveller may happen to realise more completely the truth that it is possible to be very lonely in a crowd, than when he has journeyed long down the mighty Mississippi, in one of the gigantic, splendid, and convenient steamers employed in that navigation. When for days and days together he has heard no sound but the equable working of the engine, the periodically recurring rattle of the table preparations, and the deafening noise of the dinner bell, on which sonorous instrument a negro, with grinning delight in his musical proficiency, performs a solo before every meal ; and, when after a rapid choice among the serried ranks of dishes, and a rapid satisfaction of his appetite therefrom, he has betaken himself again to the spacious gallery among his silent companions, and been thrown back on himself and his 
own reflections, he will assuredly have felt arise within him a deep longing to penetrate the mysteries of the dark woods that accompany him like a living panorama along either shore, now appearing as low thicket, and now as mighty primeval forest, above which single specimens of the hickory* and sycamore $\uparrow$ rise to the astonishing height that they attain only in the new world.

But on, unceasingly, he is borne, and whilst his charmed eye is still dwelling on some picturesque mass of foliage, - on the far stretching branches of the cotton-woodt, overshadowing the water, or on the numerous islands and islets which, flat as is the valley of Mississippi below St. Louis, render it so pleasantly varied, - he glides swiftly past the mouth of some tributary stream, catching a glimpse perhaps of a lonely $\log$-house peeping out from the shades, which attracts his attention for a moment, but is soon in its turn left far behind the panting steamer. One feels almost provoked with the craft, for the indifference she manifests to the loveliest bits of scenery, even seeming sometimes to keep perversely to one or the other bank on purpose to avoid them. Just as little does she trouble herself about the floating drift-wood that is moving slowly down the stream before her, driving the slothful swimmers to the right and left, or running them down and rushing foaming and snorting over them, as if she had been taught the shrewd doctrine, that the best and shortest way to fortune is over the shoulders of others. It is a doctrine pretty often reduced to practice in

* Inglans tomentosa. - Mich.

$\uparrow$ Platanus occidentalis. - Willd. 
American commercial life : all things revolve round the common axis of money making, and the true man of business, whatever he does, never loses sight of the question, what profit he can make by it. One need only look round on the deck of the steamer, to find this common observation confirmed. That young man there, rocking himself upon two chairs, with his feet elevated and stretched out over the railing of the gallery, and his dreamy looks fixed upon the mighty river or the glorious woods; he is probably not rejoicing, as even in that remarkable position he might do, at the beauties of nature, but calculating at how many horse power the mass of water before him may be estimated, or what might be the worth of the magnificent woods if they were cut down and sent to the New York market for fuel. That grave thoughtful looking man, who, though also rocking himself, has turned away his eyes from outward objects, which only disturb his thoughts, and chews his tobacco, and whittles away at his bit of wood without regarding them, is not really intent on his whittling, any more than on the scenery; but has chosen this occupation in order to withdraw his eyes from the glances of the companions who are discussing a matter of business with him, and so to avoid giving them any advantage by the betrayal of his feelings.

This want of sense of the beautiful in nature in the generality of Americans, is to a European as remarkable as the enthusiasm of the Europeans is to them absurd.

A traveller who should desire to take a nearer view of any attractive scenery, may land almost anywhere he likes ; for these Mississippi steamers are of such small 
draught, that they can at almost any time approach the shore, but no one would be waited for-and the admirer of nature would run the risk of awakening from his dreams of poetic beauty, to the unpleasant reality of rattlesnakes and mosquitos. Even when the steamer stops to take in wood, she is generally so impatient to be in motion again, that the men who bring the last log have to give a bold jump to get on board; and it is generally advisable for a passenger to content himself with what he can see from the deck.

At the point where the Arkansas pours its reddish coloured waters into the Mississippi, and thence accompanies it to the Gulf of Mexico, the traveller who wishes to visit the far West, bids farewell to the boat, mostly without either carrying with him or leaving behind any heart the heavier for the parting, and pursues his journey for many hundred miles up the tributary river. Some worn-out old steamers serve not only for a landing place for the little town call Fort Napoleon, situated at the mouth of the Arkansas, but also as hotels and warehouses. The luggage is hastily transferred from the boat to the shore, the owner jumps after it, the steersman pulls at one of the ropes by which he communicates with the engineer - the signal bell rings, - the paddle wheels begin to revolve again, the boat, leaning a little on one side, describes a foaming white semicircle on the water, and sweeps majestically on towards her final station of New Orleans, leaving no trace behind her but the high swell of the wave that does not subside for a considerable time.

The position of Fort Napoleon is perfectly flat, and offers no inducement to the traveller, with a prospect so much more attractive before him, to make any 
longer stay than he can avoid, especially during the summer months, when the heat in these low marshy regions is almost insupportable, and the cool morning and evening hours, which are best adapted either for business or pleasure must generally be devoted to sleep, as it is difficult to close your eyes during the night. You seek your bed, expecting that the mosquito curtains will afford you protection from this plague of the country, having opened doors and windows that the cool night air may blow through the room; but, alas! there is a drawback to the advantage of the mosquito net, - while it keeps off the hungry blood-sucker, it also prevents the refreshing breeze from reaching the weary wayfarer; he rolls uneasily from side to side in the close heated space, but perhaps drops at last into a half doze. In the meantime the mosquitos have not been idle; one of a peculiarly inquiring temper has succeeded in discovering a mesh of the net through which it is possible to effect an entrance; in he goes to be revenged on the stranger who in this land of liberty has attempted to interfere with his freedom of locomotion, announcing his tormenting presence by a hum, now loud, now low as if distant, and then again loud and close to your ear. Soon matters become worse and worse; the secret of the entrance becomes known among the brotherhood; what mosquito has done, mosquito may do, and in brief space there is a whole band of sanguinary ruffians assembled about your pillow: the victim sees the impossibility of defending himself, and gnashing his teeth, he dashes back the covering that has afforded him no protection that he may at least have the cool air to mitigate his sufferings. Towards morning he sinks into an uneasy sleep, and has only, on 
awakening in broad sunshine, the satisfaction of avenging himself on some of his tormentors who, in consequence of having indulged too freely over night, have not been able to effect a timely retreat.

Most welcome is the intelligence of the hour of departure of the little propeller which is to bear him westward ; for though he still has the special mosquitoregions to traverse, the rapid motion of the small vessel, which holds on its course day and night, and the strong draught thus occasioned, keep it pretty free from the dreaded foe.

I had landed at Fort Napoleon on the 12th of June, 1853, and had found several members of Lieutenant Whipple's expedition already assembled there, and waiting for an opportunity of getting to Fort Smith. Of course I joined company with them, but after that we had to wait two days more before the captain of the Arkansas steamer considered the number of passengers large enough to make it worth while to undertake the trip. At length, however, on the evening of the 15th, we got afloat and began to move towards the West.

The Arkansas is on many accounts an interesting river; and one striking peculiarity is the rapidity with which it varies the height of its waters. You may have seen yesterday the clayey banks rising high above their surface, and to-day the flood, which has assumed a dark red colour, is washing the roots and even the trunks of the trees upon them, and sweeping on with a powerful current; here piling up vast heaps of snags, there destroying and carrying away similar piles of wooden barricades at the construction of which it seems to have worked for years; undermining decayed trunks that you would have thought it could never have 
reached; overthrowing trunks, already half uprooted, and bearing them away as tribute to the mighty Mississippi.

In a short time, however, the decreasing quantity of the drift-wood marks the retiring and sinking of the waters; the banks rise higher and higher, and in the course of a few hours the boat requires careful steering to avoid the numerous shoals, and the above-mentioned dangerous wooden rocks which, hidden under the surface of the stream, only betray their presence by the whirl and eddy in their vicinity.

The banks from the mouth to Little Rock, the capital of the State which derives its name from the river, have the same imposing character. Throughout this extent of about 320 miles, the primeval forest may be seen in all its grandeur and glory. For thousands of years has this magnificent work of the Creator stood there untouched in its sublime repose, - what pen could describe it, or number the myriad species of grasses, herbs, shrubs, and parasitical plants, whose gorgeously coloured blossoms delight the eye? Who could even name all the kinds of trees, the various families of which are here crowded together, and whose foliage, varying from the lightest to the darkest shade of green, enriches the landscape with a superb and complete scale of colour?

Ancient grey mossy trunks, of perhaps a thousand years old, still raise their leafy crowns high above the impenetrable underwood, as proud in their fresh and youthful verdure as the slender descendants, that have but lately sprouted forth from their seeds, but under the protection of their venerable parent have already attained to considerable height. 
The first settlers have shrunk from this impenetrable wilderness, and avoided these thickly wooded and marshy grounds swarming with animal life; very seldom does the appearance of even a small clearing betray the presence or neighbourhood of man. The sound of the axe is as rare as the panting of the steamer, and curiosity in the animals takes the place of fear.

The stag stands gazing wonderingly, and without attempting to fly, at the great disturber of the place as it goes foaming by - the parrot climbs chattering from bough to bough, the turkey lifts its blue head up through the leaves, to get a better view of the new spectacle, and the black bear lying cooling his sides in the water, rears on his hind legs, and looks mistrustfully at the swimming monster and the long wreath of smoke it leaves behind. The high swell of the water, however, soon reaches him and disturbs his meditations, and he shakes his rough hide and goes off grumbling into the thicket.

The first settlers of the West felt themselves compelled to leave the dread magnificence of nature here behind them, and lay the foundations of their new home beyond the forest, where the rocks announce a gentle rising of the ground. There they felled the trees there opened the bosom of the earth, and compelled the luxuriant vegetative power of the soil, which hitherto had followed what may be called its own caprices, to employ itself in bringing forth such productions as the wants of its new masters required - and there they afterwards blasted and chiselled the rocks to build their government house, when the territory of Arkansas, favoured by nature and circumstances, had attained to 
a sufficient amount of population and prosperity to be received as a State into the Union.

Little Rock is indebted for no small part of its rapid rise to the hot sulphureous springs that have been discovered a little way to the south of it, and concerning the almost fabulous curative powers of which the most extravagantly exaggerated accounts were to be read in all the newspapers. In a short time the lame, the halt, and the blind found their way hither from all parts of the Union, in search of the health so liberally promised -and which many of them really found, though less through the merit of any of the rapidly improvised physicians, than of the salubrious climate or the really beneficial effect of the water. Even such people are welcome visitors, for they help to spread the reputation of a new town, attract new settlers, and increase many times the value of the land. In this way civilisation goes on spreading more and more towards the west, and making known the riches of the country which must be left idle until time shall admit of their being remuneratively wrought out. How long will it be before the inexhaustible bed of coal, beginning above Little Rock, at the mountain Petit Jean, shall be opened, and its products be heating the locomotives which at no distant period will unite the two oceans?

The traveller will then be able to get a better sight of the Dardanelle and Bee Rocks, which the steamer now carries him too quickly past. The first consist of an immense deposit of sandstone, in five distinct strata, each of which measures six feet in thickness, and which in its original position reached only to the level of the Arkansas; but some tremendous convulsion burst 
asunder and upheaved the bed of sandstone, so that whilst the western end is deeply rooted in the soil, the eastern rises at an angle of $45^{\circ}$ in a form not unlike a vast column. On its summit at the height of seventyfive feet the rock shows the remains of a once lofty tree, which was formerly used by the Indians as a watchtower in their warlike expeditions.

Further up the stream appear the Bee Rocks, a range of precipitous wall-like cliffs, whose rents and chasms have served, perhaps for thousands of years, as the resort of the enormous swarms of wild bees, which have given a name to the whole range. A few miles beyond the Bee Rocks, the valley of the Arkansas opens and displays the blooming prosperous town of Van Buren, surprising you as much by its pleasant appearance, as by the solitude of the wild region in which it lies.

Four miles above Van Buren, and near the little town of Fort Smith on the right bank, the river passes from the territory of the United States, and enters that of the Indians. The actual fort under whose protection the town lies, is within the limits of the Choctaw Indian territory. Immediately above this fort, the Poteau river falls into the Arkansas and not only gives the settlement an extremely pretty aspect, but also, since the fort lies at the eastern angle which the Poteau forms with the main stream, an extremely advantageous position. 


\section{CHAP. II.}

FORT SMITH. - FITTING OUT OF THE EXPEDITION. - CAMP LIFE AT FORT SMITH. - BILL SPANIARD. - TAMING THE MULES.

Fort Smith, like every other town in America, before it has well come into existence begins to think of establishing railroad communications. In the summer of 1853 , when this railroad fever had reached its crisis, a small company under the command of Lieut. Colonel Whipple U. S. S., met here on the subject of an undertaking no less important than that of marking out a suitable line for a railway between this point and Pueblo de los Angelos on the Pacific Ocean; by which it is proposed that the locomotives shall hereafter rush fearlessly through the territories of hostile Indians, establish a connection between the two oceans, and bring the gold mines of California within easy reach. For a long time this matter of the construction of a railroad to the Pacific Ocean had been a favourite subject of conversation, as well as of more serious debate, in all the western settlements; no one of the numerous little towns had neglected to furnish, in their newspapers, the most exhaustive proofs, that the line must absolutely run through their district if the advantages of good coal, excellent timber, and an admirable supply of water were not to be neglected.

For a considerable time meetings had been held, resolutions taken, deputations sent from town to town, 
the views of the locality obstinately defended, and even maintained occasionally in pugilistic encounters ; and, finally the government of the United States had organised three several expeditions, under the guidance of engineer officers, and with a suitable military escort, to traverse the country in various directions, and report concerning the several advantages of the proposed lines.

The southern expedition, to which I belonged, had to follow the thirty-fifth parallel of north latitude, commencing its labours at Fort Smith. The plan of operations best adapted to the purpose in view was at length agreed on, regard being had to the wishes of the Fort Smith people that the line should pass through their town, and the persons who were to carry the plan into execution, _ namely geologists, surgeons, botanists, astronomers and draughtsmen, twelve persons in all, were all there with bag and baggage, waggons, provisions, instruments and utensils of various descriptions ; but there were still wanting mules and labourers, two wants which afforded great satisfaction to the inhabitants, who immediately offered to supply both, the first for good payment, the labourers for nothing, and furnished moreover in many cases with good recommendations. The settlement lies too far to the west to afford many opportunities of getting rid of superfluous mules and unemployed labourers.

The mules of these regions are dearer than elsewhere, and for the most part still unbroken, but they are strongly built of indomitable powers, of endurance, and indispensable for a journey through these endless western steppes. As for the workmen, they are strong sturdy fellows, who, though wild enough, and little to 
boast of in point of morals, can turn their hands to anything that is required, know the dangers of a journey of this kind, and will fight if need be for themselves and their comrades' skins.

The long stay at Fort Smith, which the manifold preparations for so tedious a journey rendered necessary, was employed by our young and jovial troop in the enjoyment in full measure of all the delights which here, on the frontiers of civilisation, we were about soon to renounce for so long a period; and the inhabitants of the little town consequently found means not only to obtain some pecuniary profit from their guests, but also to show themselves in the light of friendly hosts, who, if it were only for their amiability, deserved to have a Terminus. They on their parts were glad to keep in good humour the men who were to help them to their railway; and so it came to pass that we were overwhelmed with caresses and coaxings, and balls and festivals given in our honour, - a course of policy to which we saw not the least objection. We had quartered ourselves with a Mr. Rogers, formerly a major in the militia, and now, in the character of hotelkeeper and chief authority in Fort Smith, reposing on his laurels ; and we found ourselves extremely contented, and well cared for at a charge of two daily dollars a head. In the evening, when the tropical heat had given way to a pleasant coolness, we were sure to find a merry party of guests assembled round the old gentleman, who entered into all their jokes, and told of many a hard tussle that he had had with hostile Indians in his younger days, and exhorted the young fellows to energy and perseverance in the work they were about to undertake. "My boys," he said, "you 
have a long and dangerous journey before you, but keep a good heart and find out the best line for the rails to California ; and when you have found it don't forget that you are not without friends in Fort Smith, who will show themselves mindful of the trouble you have taken. You come back this way. I've got land enough hereabouts that will be worth a thousand times what it now is when we have the railroad finished, and if you like to come and settle in our town - a thriving one it will be then-I'll give every one of you a plot for building on that you may choose for yourselves."

The well-meant offer of the old gentleman was received with a shout of acknowledgment; the party swore to find a suitable line for the railway, even though a dozen Chimborazos or Niagaras should be in the way to be climbed or swam over; they drank in jovial mood to the success of the journey, to the prosperity of the new railroad, to that of the old major, to Fort Smith, to their own newly acquired freedom of that famous town, and merrily began to choose forthwith their respective plots of building ground. A young New Yorker, who was a shrewd speculator, selected a piece of land close to the future terminus, where he said he would build a hotel and entertain the Californians when they came back loaded with the precious ore and dust; a Frenchman picked out a hill near the town, which he said was the very thing for a vineyard, and grew upon it imaginary Burgundy and Champagne; an Irishman pointed out a spot to the left of the major's house, where he said he would set up a distillery; and a German chose a place on the right, on which he ran up a magnificent castle in the air and regaled his friends therein with splendid Bavarian beer. The major 
declared himself quite satisfied with these arrangements, and till a late hour in the night glasses were clinked, hurrahs resounded, and the rattling tunes of a band hastily brought together, were outdone by our vocal performances. The pauses were filled by popular melodies of the various nations there represented, and it afforded the German great satisfaction to observe the deep impression produced, here in this far distant land and remote outpost of civilisation, by the simple and genial songs of his country, In einem Kuhlen Grunde, and Ich weiss nicht_was soll es bedenten?

These pleasant festive nights at Fort Smith were, however, soon at an end. In order to accustom ourselves to a camp life and discover practically any defect there might be in the equipment of the expedition, while it was still possible to supply it, we determined to take up our abode pro tem. in a forest clearing not far from the town, and pitched our tents accordingly in a spot protected from the burning rays of the sun for the greater part of the day by the overhanging boughs.

'The party, including a military escort under the command of Lieutenant Johns, consisted of above seventy persons; and the whole expedition was under the orders of the engineer, Lieutenant Whipple, a man who had already distinguished himself in similar undertakings, and to special professional qualifications united the advantage of particularly pleasing manners, which inspired confidence in all who approached him.

In a very short time we were all quite reconciled to our new mode of life, and by the time the charm of novelty was worn off, the power of habit had come in to reconcile us to the inconveniences, small or great, which are not easily separable from a bivouac. One 
sleeps well enough upon the ground when one has no choice, and scorpions and tarantulas soon lose their terrors; you learn to bear the heat when it must be borne; if you get wet, the rain cannot penetrate further than the skin; and broiled meat, and black coffee sweetened with maple sugar, make a superb meal when there is nothing better to be had.

In a very short time a very friendly, not to say brotherly feeling, had grown up among our little community, although it consisted of very heterogeneous elements, men of various nations flung together at random; and it was not the jovial doings at Fort Smith, the wine and the hurrahs, that had tended to awaken it, so much as the thought that for months, perhaps years, we might be thrown upon each other's society, and the tacit understanding that through the toils and dangers of our journey through the pathless wildernesses of the far West, we would be mutually and cordially helpful to one another.

Every morning the party might be seen leaving the camp in joyous mood, and dispersing in all directions to set about all kinds of little preparatory labours. The geologist would get down to the river, and hammer away among the stones till the woods echoed with his industry. The botanist had discovered on a certain tree a remarkable parasitical plant, and regardless of expense in the way of torn garments, was working his way towards it, through a close and tangled growth of thorns and underwood and tough obstructing creepers, and then with still greater labour up the mighty trunk on which it grew. The naturalist had caught sight of a lizard that tempted him into the thicket, and then kept eluding his pursuit — now among the dry rustling 
leaves remaining from last autumn - now within some decaying trunk - until at last it took refuge in a hole under an immovable block of stone, and would have been irrecoverably lost had it not left exposed a small extremity of tail, of which the enemy managed to catch hold. The surveyors and chain-men follow the direction indicated to them by the compass, and work on till the almost vertical rays of the mid-day sun drive them back to the camp, where they generally find the whole company assembled, pretty well tired out with the work to which as yet they are little accustomed.

When the lizards, snakes, frogs, toads, and other treasures have been deposited in spirits, the butterflies and beetles plaeed on their respective pins - the plants and flowers comfortably tucked in between sheets of paper - and the dinner, at which various good things are still to be found, satisfactorily disposed of,-every man looks out for a convenient place in the shadow of his little tent, and prepares to sleep away, as well as he can, the oppressive hours of afternoon heat. Soon the only sounds heard are the low humming of a negro melody, the chatter of the parrots on the nearest trees, the chirping of grasshoppers, the hum of bees, or the heavy slumberous sounds that suggest the fatigue of the morning. The man whose duty it is to keep watch over the sleepers, lolls carelessly against the trunk of a tree, and the two who are to relieve him wile away the time in the shadow of the great tent which serves as guard room, with a game of cards, the cards being of such hoary antiquity that it is scarcely possible to tell one from another.

One day there lay at a little distance from the tents, two men stretched out beneath a sassafras bush, who 
were carrying on a very animated conversation, and apparently not at all incommoded by the heat of the sun. The peculiar cut of their features, their dark skins, the lank hair falling on their shoulders, and their expressive gestures would have stamped them as Indians, had not their thick rough beards afforded them some apparent claim to a European descent. They were very carelessly dressed in a garment of rough red flannel confined by a broad leathern girdle, which served at the same time to hold the knives and pistols, which their owners evidently took great pains to preserve from rust. They had only been engaged to accompany the expedition a few hours before; and after a few glances had convinced them that there was much resemblance in their origin and circumstances, they had made acquaintance, and at the time I speak of seemed about to enter on some reciprocal confidences. "My name's Bill," began one of them - a gloomy looking man, with a deep sear in his forehead, of low stature and very thick set, and giving evidence in the breadth of his shoulders of gigantic strength - "my name's Bill, but they mostly call me Bill Spaniard, because my father came from Spain, over the great water. My mother was a Cherokee woman, and I am, as far as I know, her only son. I don't know how nor where my father and mother died, but I grew up in the wigwams of the Cherokees, and I managed when I was quite young to earn enough among the whites to buy myself a pair of pistols, and powder and ball. At first I used to amuse myself with the sound of them, but afterwards I thought it better fun to shoot the cattle belonging to the pale faces, and bring home the tongues and as much meat as I could carry to my people. The settlers used to call 
me a thief, but I did'nt think so. I'm half an Indian, and have been always among Indians. I've stolen many a horse and been proud of it, but I never took anything from my friends and brothers."

After a short pause, Bill resumed. "There was a great villain down there among my people; he used to steal from his friends and from his own brother, and then he always said Bill Spaniard, the light Cherokee, had done it. He was a liar, and I showed them that he was, and he wanted to stop my mouth, and swore he would be the death of me. He used to follow me with his double-barrelled gun loaded-I've counted the bullets he put in; and one day he met me on the other side of the Arkansas, and called me a red-skinned rascal, and pointed his gun at me; but my hand's pretty quick and my eye quicker, and I hit him with one of these little pistols just between the eyes. It wasn't for nothing I had bought pistols and learned the use of them. My enemy lay at my feet." He was silent again, but he snapped his pistols in a sort of caressing manner, and stuck them again into his belt, then pulled a roll of black tobacco out of his pocket, cut off a piece, pushed it between his white teeth, and went on. "A relation of my enemy accused me of murder, and I was sent to prison, and there I was kept for six years; but then my accuser died, and I was set free. I shall get out of this country, for I hate all the people here, and go to California and dig for gold. I can work well, and I shall get rich."

"Bill," replied his companion, a half-Indian like himself, and no less strong a fellow, "you must mind and keep out of harm's way. I'm going to California, too, along with this party. I a'nt comfortable here. 
People say I have stabbed a white man and a Choctaw Indian, and I don't like such talk."

"You're a great villain, you are," said Bill, "and they'll hang you yet-but there come our mules, we must go to work." At these words both rose and went off in the direction where a loud trampling announced the approach of the still wild mules, in taming and breaking which the two half-breeds were to show their strength and skill.

One of the most difficult tasks in the preparations for a journey through these steppes is the breaking and shoeing these animals, whose strength and power of enduring fatigue, even under a scarcity of food and water, is incomparably greater than that of the horse. In situations where the latter, even though relieved of all burden, can scarcely drag along his exhausted limbs, and must perhaps at last be left behind as a prey to the wolves, the mule goes on patiently bearing his burden, and fighting against the dreadful enemy hunger by the way, by cropping the withered plants of the marshes, or even prickly brambles. But as the strength of the horse and the perseverance of the ass are in some measure united in the mule, so does he also unite in his own person almost all the faults that can make horse or ass intolerable - timidity, obstinacy, perverseness, cunning, are the qualities with which one has to contend in them, especially in the process of breaking; and the difficulty is increased when the herd consists of animals hitherto unacquainted with one another, who have to make acquaintance by means of a fierce battle among themselves; and as many have usually been sold by former owners on account of incurable vice, it is often necessary to have recourse to severe and even cruel methods to 
subdue them. For this, which is no light labour, the assistance of Mexicans and Indians is almost indispensable. These people seem to have a kind of instinct by which, after a very cursory inspection of the herd, they can find out the most unmanageable animals in it, and they make it their business to catch them first.

The Arriero, as he is called, is provided with a long line or lasso ending in a noose, which he holds in loose rings in his right hand, and as soon as he has made up his mind which animal is to be his victim he gallops round and round the herd, now anxiously crowding together, and watches for a favourable moment when the mule shall expose his head. The moment he has done so, the Arriero whirls the lasso round his own head, and then flings it dexterously over that of the shy mule, which rears and kicks in indignation at the loss of its freedom. But the lasso is now round his neck, and the more he struggles, the tighter it becomes, so that in a very short time the exhausted creature feels that if it does not mean to be choked, it is necessary to admit the cogent reasoning of his antagonist, and he allows himself to be drawn under a sort of scaffolding, with four upright posts, between which he has just room to stand. The animal is then lifted, by means of a cleverly contrived tackle, about three feet from the ground, one of its legs is attached by leathern thongs to each of the four posts, and before it can look round or guess what is going to be done, four smiths standing ready with iron and tongs have completed a work which, even with a quiet horse, usually takes ten times as long. As soon as the shoes are in their places, the frightened creature is delivered over to the waggon driver, the exhortations to obedience are repeated, with 
illustrative remarks, with the whip and the lasso; the well broken mules with which the novice is harnessed set him a good example, and his fits of rage become less frequent, until, in a relatively short space of time, the new mule is declared fit for service, and associated with his already tame brethren. 


\section{CHAP. III.}

THE LANDS ON THE RIVER POTEAU.-THE INDIANS.-THEIR SETTLEMENTS. - PASSAGE OF THE POTEAU. - THE STORM. - FORT KOFFLE.

The luxuriantly wooded shores of the Arkansas, beyond the point where the Canadian river falls into it, are agreeably diversified by small prairies, which from time to time form openings in the thick forest.

The Sugar Loaf, the Kavaneau, and the Sans-bois mountains bound really paradisaical valleys, over which Nature has poured out every kind of loveliness with inexhaustible profusion. The meadows, which are perfect beds of splendid flowers, tempt the traveller almost irresistibly to linger, or even take up his abode in them. They are ready to receive whatever seed he may drop into their bosom and to return him a thousand fold; and the numerous little streams, which constantly refresh the soil, dispel the fear of the excessive heats of summer, and promise a joyful harvest; while the neighbouring woods offer the settler hard hickory trunks for the beams of his log-house, and slender stems enough for his fences. The winter is here milder than in most of the neighbouring regions; for the impenetrable woods and the near mountains defy the north wind and protect the tenderest germs from this enemy so dreaded in less favoured regions. Even the Red Skins were not able to resist such attractions, 
and when the covetous Pale Faces drove them over the Alleghany mountains and across the great river, the already half-civilised races of the Choctaws, Chickasaws, Creeks, and Cherokees, who had left the graves of their fathers and their hunting-grounds in the far east, gave up their unsettled nomadic life, and took up their abode in these western regions. In this new home they sowed and reaped, and learned from the grateful soil what the missionaries had long preached to them in vain, and what the selfishness of their white neighbours, who shamefully denied their capacity for culture, had constantly hindered them from learning.

Every Indian is capable of civilisation, if only his first introduction to it is such as to awaken confidence, and do away with the mistrust that has existed for centuries among his people. From his first acquaintance with the European intruders he has been driven through the country like a noxious animal, flying continually from the arrogance of the whites, and often, through their unprincipled policy, engaged in bloody strife with brother tribes, or wickedly encouraged in his plans of vengeance for the thousand wrongs inflicted upon him by the professors of a religion of love, in order that they might obtain a justification for their own unchristian and treacherous behaviour. How, under these circumstances, should he have learned anything of the blessings of a peaceful settlement, of a cultivation of the soi], and of a regular and orderly life?

If there are, nevertheless, tribes to be found, who, without having entirely renounced the customs or the character of their forefathers, have become peaceful citizens, industrious cultivators of the ground, and well 
conducted, hospitable men, the very smallest part of the merit assuredly is to be ascribed to the Europeans. It has been almost wholly the result of the spontaneous development of the germs of culture and of all good, which, after long slumber, have at length burst forth under the least favourable conditions. It is delightful to the traveller to go from settlement to settlement among these Choctaws and Cherokees, and to find himself everywhere received with open arms like an old friend. Here the wanderer need have no fear of a rustling among the bushes, of the hissing arrow or the whistling tomahawk. The crow of the domestic cock mingles with the call of the little partridge, and the moaning cry of the panther has been long silent before the barking of the house-dog; and where once was heard the wild howl over slaughtered enemies and bloody scalps, you now listen to the peaceful bells of the grazing flocks and herds.

The yell of the Indian here only serves to awaken the echoes of the neighbouring mountains and woods; - a single Red Skin may be seen following the traces of the bear and the panther, into the deepest recesses of the forest - but he shoots the stag from his own door, while it is trespassing upon the corn, which he has sown and desires to reap. One might be tempted to envy the Indian the quiet happiness of these valleys, if one did not most heartily rejoice in his possession of it, and the victory which, under many disadvantages, he has obtained over the wildness of his former state. Here are blooming farms which would do honour to a European settler, luxuriant crops, and a general prosperity that enables such of these sons of Nature as aspire to higher culture to seek it in the Eastern States. 
He sees the wife of the Indian no longer degraded to be the slave of her husband, but receiving the honour due to her as a wife and a mother.

These new disciples of civilisation have learned from the whites to keep negro slaves for house and field labour; but these slaves receive from their Indian masters more Christian treatment than among the Christian whites. The traveller may seek in vain for any other difference between master and servant than such as Nature has made in the physical characteristics of the races; and the negro is regarded as a companion and helper, to whom thanks and kindness are due when he exerts himself for the welfare of the household.

These pictures of content and domestic peace must not, however, be sought for too near the settlements of the whites, and also not at the time when the government of the United States sends its annual payment for the lands sold and ceded to them by the Indians ; and when cruel speculators find means to get the greater part of the treasure, just received, back again into the hands of the whites.

The most efficient means for this miserable purpose is of course "fire-water." A small quantity of this poison is enough to rob the Indian of his reason ; and when one of them has in the madness of intoxication parted with what he has become possessed of but an hour before, and which might have helped him to a comfortable existence in future, the speculator, having ascertained that there is no more money to be got out of him, drives him without mercy from his door. The wretched creature then goes wandering about, and though he certainly might get some work that would keep him from starvation, the fatal desire for fire-water, 
once awakened, leaves him no longer capable of rational action. An Indian in this lowest state of degradation wanders from settlement to settlement, and from door to door, and is detested and trampled on by the very men who have caused his ruin; and travellers who happen to come across such specimens are too apt to draw from them inferences concerning the whole nation, and to associate with their name the combined vices of the white and the copper-coloured races.

On the 15th of July 1853, the expedition under Lieutenant Whipple left the camp at Fort Smith, and in accordance with the previously arranged plan, crossed the river Poteau, which was easily done as the garrison boat could be used. Once on the other side, there was nothing for the long train of waggons to do, but to follow the road along the marshy bottomlands on the sharp angle formed by the Arkansas and Poteau. The surveyors had to pursue their labours in this crooked route, on which it was not possible to describe a long straight line, since the thick growth of canes, which had taken the place of underwood beneath the high cottonwood trees and sycamores, did not admit of any considerable deviations from the path we were following. After a few miles, the road began to rise, and Indian farms glimmered occasionally between the impenetrable masses of forest. The old road, in laying out which the endeavour. had been to avoid the more considerable obstacles, and take advantage of every little opening in the woods, was not in a state to admit of rapid progress with the waggons. Roots of trees and decaying trunks every moment arrested the procession, and since the thick shade of the overhanging boughs had prevented the drying of the ground, the last of the 
twelve waggons (each drawn by six mules) had to be literally drawn out of the mud, as if from a morass. Scarcely had we reached the higher ground on which the waggons could roll easily along, and the beasts of burden obtain a firmer footing, than the oppressive heat was varied by a tremendous storm, by which the whole cavalcade was thrown into disorder. There was a clearing near a large plantation not far off; and after the waggons had been with some confusion drawn thither, we all hastened to get the mules unloaded and unsaddled, so as to allow them to run freely in a herd, and then everybody endeavoured to find the best protection he could for himself. Considering that this was our first day of march, and that our party was as yet scarcely organised, it will not appear surprising that it presented at this moment a somewhat dolorous and at the same time comic aspect. The high spirits of most of us had gone down, in some cases very low indeed, and one or two tender youths had taken refuge under the waggons, and were shutting their eyes from the glare of the lightning; others who liked to display their hardihood, as well as the really hardy workmen, lay down wrapped in their blankets on the grass; but it might be observed that while the workmen soon fell asleep, the gentlemen had to stuff their blankets in their mouths to keep their teeth from chattering with cold, occasioned by the thorough wetting they had got. The most cautious and prudent of the party set about putting up a tent, and after many a vain attempt had just succeeded nicely in the unaccustomed work, when the sky cleared up, and the sun looked laughingly out upon the drenched and deplorable figures.

Some of the most practical of the party had never- 
theless found means to shelter themselves pretty successfully, by spreading the blankets over the bent boughs of a shrub, and then digging with their knives a canal round it; while their saddles placed in an inverted position formed a sort of chair, on which their weapons and their persons remained high and dry under their dripping canopy; the rain running off through the channel they had dug for it, and the hunched up occupant of the bower pursuing his meditations on the beauties of nature undisturbed.

In the meantime the black clouds had covered the whole horizon, and enveloped the entire landscape in gloom; the lightning, flash after flash gleaming from all points of the compass — drawing dazzling zigzag lines, and lighting up the dark masses of the woods with a peculiar magic splendour. The storm violently shook the tops of the highest trees, as if in rage at not being able to find an entrance beneath their dense canopy heavy claps of thunder succeeded each other with only intervals of a second or two, just sufficient to enable us to hear the roar of the distant storm, the downward rush of the rain, or the fall of the decayed trunks of trees. Just as the tempest had reached its climax, a glare of lightning, accompanied by a deafening burst of thunder, struck the extreme summit of a mighty hickory tree-a crash followed, and the tree was cleft from the top to the root.

What a magnificent display of force! But the awful power which had drawn these threatening clouds together, which by the lightest touch had cleft the tree and shaken the rocks, now bade the clouds disperse, the rushing rain and roaring wind cease, and the blue sky to appear again. The heavy drops pouring 
from the leaves, now made almost more noise than the thunder which was rolling away at a distance, whilst the lightning showed faintly in the far east; and the beams of the setting sun burst forth glittering upon millions of rain drops, and with its encouraging smile animated every one to fresh exertion. The frightened herd of mules, which had been crowding anxiously together, now dispersed grazing in all directions, our camp fires began to crackle and blaze, and every one looked out for the driest and most comfortable spot he could find, in which to pass the night, and gain new strength for the morning's march.

At the distance of about a mile from the river a road runs through the valley of the Arkansas, as far as the Choctaw Nation Agency, about fourteen miles from Fort Smith. The paths which occasionally cross it are only those made by the Indians, with one exception, namely, that of a bye road which strikes off five miles before you get to the Agency, and runs to Fort Koffee on the Arkansas, and thence again in a straight line to the Agency, after rejoining the main road, which here crosses a broad prairie. The bye road leads entirely through the forest, which here assumes quite a different character, consisting wholly of dwarf oaks, and the underwood being replaced by luxuriant grass and flowers. Northward from the road a solitary hill of conglomerate rises a hundred and fifty feet from its base; it is but scantily wooded, and affords from its summit a fine prospect over the valley of the Arkansas, to where, near Van Buren, the horizon is bounded by mountains.

The most noxious and poisonous animals of the whole region seem, however, to have made this hill their headquarters. Just as you reach the top you find, perhaps, 
the copper-head snake, rolled up into a ball, but stretching his head towards you, darting his tongue out, and seeming to measure the distance between him and the foreign disturber of his peace, while preparing for a spring. If you happen to roll away a stone from the place where it has been lying, you are sure to find a whole nest of scorpions beneath it, the largest about three inches long and the smallest scarcely perceptible, but raising their tails, armed with poisonous stings, in the most hostile manner. As this is not quite pleasant company, you make but a short stay on this hill, and a short time after you have left it, at a sudden turn of the road, you see old Fort Koffee lying before you. This little fortress was erected thirty years ago, as a defence against the Indians, and named after its founder, the American general Koffee. It is beautifully situated on a hill about eighty feet high, that rises abruptly from the waters of the Arkansas, and on the landside slopes gently down; and the white building gleams out pleasantly from the dark cedars. After the building of Fort Smith, however, Fort Koffee lost its garrison, and was, twelve years ago, transformed into a missionary school house, and the buildings erected for a warlike purpose have since then been turned to account for peaceful ends. Well cultivated fields of maize and wheat lie close round the gardens, in which negro slaves are sometimes diligently at work and sometimes loitering leisurely about; while groups of dark-coloured children at play peep out curiously with their black eyes at the passing wanderer. The school is supported by the American government, and under the guidance of a married Methodist preacher. On an average about fifty of the young Choctaws are receiving their education 
here, and a similar institution for girls was a few years ago established nearer to the Agency, and is now apparently very prosperous, and producing good fruit. The way from the Mission to the Agency leads along the side of a spacious prairie, sometimes crossing parts of the grassy plain, sometimes cutting off small tracts of light wood, and at last, when near the Agency, turning into the deep forest, when after proceeding for a short distance you come again upon fields of maize and wheat, and log-houses, surrounded by flourishing young fruit trees, which announce the commencement of the rising Indian town.

The town itself consists of a kind of broad street, formed of log-houses and gardens, and does not differ much in appearance from many other thriving villages ; Indians, Negroes, and Europeans are seen moving about-domestic animals of all sorts enliven the farmyards, gardens, and streets; the sound of the threshing machine is heard, and the regular fall of the smith's hammer upon the anvil, and in general there is an appearance of lively industry about the place, called by the Indians Hei-to-to-wee, but by the American population Sculleville, or simply the "Agency." 


\section{CHAP. IV.}

SCULLEVILLE. - THE CHOCTAW AGENCY. - TRADITIONS OF THE CHOCTAWS. - CHOCTAW COUNCIL. - SANS-BOIS CREEK. - PINE GROVE. - BALL PLAYING AMONG THE CHOCTAWS.

In order to protect the Indians from the oppressions of the whites, and transact their affairs with the government of the United States, as well as to maintain the interests of the whites among their red-skinned brethren, agents have been placed among the various tribes, and have generally become the founders of a settlement. Not only Indians, but whites also, are willing to settle in their neighbourhood; the latter of course with a view to gain, and to being always at hand with goods for barter. In this manner arose the town of Sculleville. The Agency, with the buildings necessary for cattle-breeding and agricultural purposes, lies on a little stream, or rather spring, which gushes out from the rock, and increasing with every step, hastens towards the Arkansas, between which river and the Poteau the Agency is equidistant.

A smith's forge and storehouses soon made their appearance, and before long well managed farms, surrounded by beautiful orchards and corn-fields, and the Agency became the rendezvous of all the industrial population of the country as well as of the vagabond Indians. The want of an inn was soon felt; for the Indians, both men and women, were now often un- 
accustomed to sleeping on the ground in the open air, and a small boarding-house helped to render the little town complete; and there may sometimes be seen alighting at it Choctaw gentlemen and their families who have been to visit their daughters at school.

Although the Indian population is of course accustomed to intercourse with whites, the appearance of our expedition, with its military escort, attracted a great deal of attention, especially as we proceeded to pitch our camp near Sculleville, evidently with the intention of making a stay of some days. It happened, also, that a council of Choctaw chiefs was being held at the same time, so that it was no wonder if people flocked to the spot from far and near, and that the town assumed its gayest aspect. Men and women all appeared in their best clothes, which, though cut in the European fashion, exhibited glaring contrasts of bright colours and many fantastic and most untasteful decorations. The camp was the great point of attraction, and as I had set up a kind of studio in my tent, many of the Indians came crowding that way, evidently speculating on the chance of having their portraits taken in their splendid full dress. Arrangements for running matches, shooting matches, horse races, dances, and especially for grand games of ball playing, which are peculiar in their kind, came off with great celerity; wonderful things were to be done in these few days; and certainly a traveller may esteem himself fortunate who arrives at Sculleville at the time of a great public meeting of the Choctaws, for he may then learn in a short time, from his own observations of this interesting people, more than he could gather by mere inquiry less satisfactorily in a much longer period. 
The nation of the Choctaws is stated by Catlin at 22,000 , who now occupy the territory southward of the Arkansas and Canadian rivers, - bordering to the east, on the state of Arkansas, to the south on the territory of the Chickasaws, and to the west on that of the Creeks. The northern neighbours of the Choctaws are the Cherokees, who stand at about the same grade of civilisation, and differ but little from them. The differences that exist are chiefly to be found in some ancient customs and traditions, which appear to depend upon their origin. Before their settlement on the Arkansas, the Choctaws occupied the rich hunting grounds of the States of Alabama and Mississippi, which they sold to the United States, agreeing that the payment should be made by regular instalments in the course of twenty years. This term is now nearly expired, and most of the money has found its way back into the hands of the whites, having done the Indians little good by the way. If we compare the current traditions still to be found in these regions with one another, we shall easily come to the conclusion that this tribe must at one time have lived in the Rocky Mountains, to the north-west of its present territory, as neighbours of the Flat. Head and Chinook Indians. These are the only tribes who disfigure the natural form of the skull, by squeezing the heads of the newborn infants between boards; and old Choctaws state that they have heard from their forefathers of the former prevalence of this custom among them. This is confirmed by the tradition of their great migration, which as related by an Indian runs thus:-

"Many winters ago, the Choctaws lived far away towards sunset, behind the great flowing water (west- 
ward of the Missouri), they lived behind the mountains with snow (the Rocky Mountains). They then began to wander, and they passed many winters and many summers in wandering. A great medicine man was their chief; he led them the whole way, and he went always first, carrying a long red pole in his hand.

"He walked always foremost, and wherever he struck the red pole into the ground, they pitched their camp; every morning they noticed that the red pole was inclined towards sunrise, and the medicine man declared this signified that they were to go on till it remained standing upright, by which they would know that there was the place that the Great Spirit had destined for their home. They wandered on and on for a long while, until at last, at a place called Nah-ne-wa-ge, (precipitous hill) the pole remained perpendicular. They then established themselves on the spot, and made a camp a mile long and a mile broad; and the men lay down around it, and the women and children in the midst ; and Nah-ne-wa-ge is still regarded as the centre of the Choctaw nation."

Although the traditions of the Indians offer no very firm footing for chronology, it is often possible, by a comparison of them with those of other and distant tribes, to obtain some sort of approximation to the truth. The tradition of a great flood is to be found among the Choctaws, as well as among the Aztecs, and among many tribes eastward of the Cordillera of South America.

"There reigned," they say, "an impenetrable darkness over the whole world, and the wise medicine men tried all kinds of methods to overcome this gloom, and looked long for returning daylight. But their labour 
was vain; and the whole nation sank into great misery. At length, after long waiting, they saw a light rising towards the south, and they thought the end of their sufferings was at hand, when they perceived that the light came from mountains of water which rolled on and overwhelmed the whole nation except a few families, who, foreseeing the misfortune, had built themselves a raft, upon which they were saved, and became the progenitors of the present Choctaws."

Christianity has found its way to these people, but still many of them remain attached to the faith of their fathers, which promises them the continued existence of their souls after death, and is in its main points nearly the same as that of the Northern Indian races.

The deceased Indian has, according to them, a long journey to take towards the West, until he comes to a deep rushing river, which separates him from the happy hunting grounds. The two shores of this river are connected by a long pine trunk, stripped of bark and polished, which must be used as a bridge. The good man passes with a firm and secure step across this slippery bridge, reaches the happy hunting grounds, and enters on the possession of eternal youth and strength. His sky is always clear, a cool breeze is perpetually blowing for him, and he passes his time in sailing, hunting, dancing, and boundless felicity. The bad man, when he steps upon the bridge, sees the two overhanging shores totter, he attempts to escape, and falls into the abyss below, where the water is rushing with the sound of thunder over rocks, where the air is poisoned by the exhalations from dead fish and other animal bodies; and the water, whirling round and round, brings him always back to the same point, where all the 
trees are withered; where it swarms with lizards, snakes, and toads; where the dead are hungry and have nothing to eat; where the living lead a diseased life and cannot die. The shores are covered with thousands of these unhappy beings, who climb up to get a glance into the happy hunting grounds, which they can never enter.

One likes to listen to the tales of these people, and the Red-skin lingers with mournful earnestness over their embellishment when they concern his forefathers. An incredulous smile will bring him to a stand-still at once and induce him to break off; but when his quick eye discovers sympathy in his hearer, he brings out one tradition after another, and you willingly follow him through all his wild fancies, and do not care to lose one of the slowly uttered words.

"The Crawfish Band," I was informed, "were now joined with the rest of the tribe, but they lived formerly in a great cavern, where, for miles and miles round, there was no light. They used to crawl out to the daylight through a marsh, and return in the same way. They looked like crawfish, went on hands and feet, did not understand one another, and were very shy and fearful. The Choctaws watched for them a long time, to try and speak to them, but they would not speak to anyone, and vanished again into the marsh. At last the Choctaws found means to cut off their retreat to it, and then they escaped to a neighbouring rock, and disappeared somehow in its crevices. The Choctaws then brought fire to the entrance of the cavern, laid grass and green boughs upon it, and drove in the thick smoke, by which means they at length drove out these crabmen to the light of day, but treated them kindly, taught them to speak and to walk upon two feet, instead of on 
all-fours, cut their long nails, plucked the hair from their bodies, and afterwards incorporated them with their own tribe; but many of them, after all, went back to burrow in the earth, and are still living in the great dark cave."

So run the traditions of the Choctaw Indians; and when you hear them related by the people in their peculiar manner, you become more and more eager to make out some light points in these dark old stories; but it soon becomes obvious that you can never found upon them anything more than very uncertain conclusions.

We will now turn to the Council of more civilised Indians, and admire the eloquence displayed in it.

At the western end of Sculleville lies a small warehouse (with a somewhat raised corridor), which is the rostrum of the Choctaw orator, and the open sky the ceiling of his hall. "The Indian orator," I was told, "finds his speech flow freely when his eye falls on the swallow shooting through the air; when he sees before him the tree with its beautiful green leaves, his words grow together like the fresh leaves, and form one whole, for there are many leaves on one branch and many branches on one tree; the tree throws a shade so that many men can stand in it, and his speech falls like a shade upon the hearers, and every one says the speech is good. The wild bee goes murmuring past with her honey, and the speaker takes the honey and mingles it with his words. Honey is sweet; the Red-skin likes to eat it; and the hearers of his words suck them in like honey, and every one can understand the words, and listen to them sharpeyed and motionless, like the antelope in the prairies and the stag in the thicket."

On a magnificent summer evening, the whole mascu- 
line population of Sculleville was assembled before this rostrum, and of the camp of Lieutenant Whipple very few were wanting. The Indians had mostly brought their wives with them, but the ladies were too modest to approach the Council, and remained at a distance; for although the wives of the Choctaws have now assumed something like their rightful place, and are no longer slaves to their husbands, as among most uncivilised nations, they are themselves reasonable enough to see that the interference of a single woman in political affairs would sometimes do more than the men of the whole tribe could make good again. It will probably be a long time before the emancipation of the sex is to be looked for amongst the Choctaws.

The first orator who presented himself, though a great chief, was no painted and plumed warrior. He wore a cotton hünting-shirt of rather fantastic cut, a brown low-crowned hat shaded his copper-coloured physiognomy, he looked dusty, as if from a long ride, and his horse, still saddled and bridled, stood a little way off.

From his first word the most breathless stillness reigned, and every one listened with profound attention, even those among his auditors who were entirely ignorant of the language in which he spoke. He had no time for preparation, but he knew what he wished to say; there were no theatrical gestures, or attempts to excite the passions of his hearers, but merely a light movement of the hand occasionally accompanying the most emphatic words, which although uttered in deep guttural tones, were distinctly audible to the most distant of the assembly. He spoke with ease and freedom, and was interrupted neither by applause nor 
contradiction ; only a unanimous Hau! followed on certain questions that he asked, and when he had ended there was a short murmur of remarks among his auditory, and then another orator took his place.

The questions in discussion were, first, a proposal for running the railroad across a part of the Choctaw Land, to which it is probable that the circumstance of our party being encamped on the spot had given rise; and, secondly, a change in the form of government, as it had been proposed that the power now distributed among several chiefs should be delegated to one.

The judicial business is conducted in the same manner; and the Choctaws are strict and inflexible in the administration of justice. The punishment of death is sometimes inflicted, in which case the delinquent is seated opposite his judge, cross-legged on the same blanket, and when he is condemned receives his death by a bullet on the spot.

The sitting on the present occasion was prolonged to a late hour of the night, one speaker following another without any interruption, and the same attention being paid to the last as to the first; even those who did not understand a word were not tired, and the effect of mere tone and gesture upon them was such, that an American exclaimed, "I used to think English was the finest language in the world, but now I doubt whether Choctaw does not equal it."

On the following morning our party was again dispersing in small groups about the dark forest paths, for as the expedition was now complete in its numbers, it was intended that it should be soon again in motion, in order to approach the great prairies by easy marches, and so, while accustoming the men and animals to their 
work, to keep their strength undiminished for the privations they must expect in the immense and often arid steppes through which they would have to travel. The further you go from the Poteau, and the nearer you approach the Sans-bois Creek, the lighter become the woods, and the more frequent the pleasant green prairies; here and there occur ranges of hills, in the neighbourhood of which the country loses its fertility; the sandstone lies near the surface, the upper ridge of the mountains consisting of strata of sandstone lying from south-east to north-west. In the woods some cedars are to be found, but chiefly oaks in such amazing variety, that it would not be difficult to collect from five and twenty to thirty different species.

The country is rich in springs and streams flowing towards the Sans-bois, which, proceeding from the southwest, pours itself into the Arkansas some miles below the mouth of the Arcadian. These waters are good for drinking, and swarm with fish, the majority of which belong to the various species of Pomotis. The bull-frog makes his voice heard from every bank, as loudly as if he were autocrat of the whole region, but he is really so timid that at the slightest sound he goes down splash, heels over head, into the water to hide himself. The black snake (Coluber constrictor, L.) creeps cautiously through the bushes in search of his - prey, while the gigantic diamond rattlesnake (Crotalus rhombifer, or adamantinus, ) lies in wait for it, rolled up between the rocks, and allowing the beautiful little chameleon to spring over him uninjured.

Near the Sans-bois mountains the road winds between a chain of rocky hills, where a heavy train can make way but very slowly, and whoever is in possession of a 
good mule, tired of the creaking of the waggons and the perpetual cries of the mule drivers, is fain to seek a path for himself, even at the risk of losing his way, especially as the risk is not great, the woods being light, and the meadows that so frequently interrupt them affording the traveller such a wide prospect that it is not difficult to find the track of the waggons again, should he lose it.

In these little solitary excursions, the wanderer, besides coming from time to time upon an Indian farm, where he has a good chance of obtaining rural productions at a small price, and meeting with little adventures, has often the good fortune to fall in with various scientific treasures; such, for instance, as the most beautiful specimens of fossil ferns, in the beds of small streams, upon inclinations of beds of coal visible on their banks, or upon new kinds of cactus which seem to announce the approach to the Flora of Texas.

On the north side it is easy to ride up almost all the hills, but they are very abrupt and precipitous on the south, so that great care is required to descend these steep rocky declivities without coming into much closer contact with the stones upon them than is desirable. But presently from this declivity you obtain such a wonderful view, that you are continually tempted to repeat the not very safe descent, by climbing the hills at various points. When you reach the rather higher plateau which, on account of a few crippled pines, has received the name of Pine Grove, such a landscape is opened to the view, that any one must indeed be dull and insensible who can contemplate it without not merely surprise but emotion. 
The whole country of the Choctaws lies there unrolled before your eyes, and looking to the east whence you have come, you see for the last time the Sugar Loaf mountain on the borders of the State of Arkansas, and a low chain, scarcely distinguishable in the horizon, passes behind the dark masses of the Cavaneau, which are met by the mountains of Sans-bois, the highest points of which, due south from Pine Grove, gradually sink towards the west, and lose themselves in the flat country.

The great valley, lying thus like a picture framed in by blue mountains, is by no means a level surface varied only by the distribution of forest and prairie, although that will often compose a scene of great beauty, but hills and even mountains lie scattered about it in all directions, and the green prairies and dark woods are intersected by streams and rivulets, the windings of which are traceable through the meadows by the bushes on their banks, and through the forest by the deeper green of the trees. The wood country seems to roll away from the Pine Grove in vast waves, till it is arrested by the Sans-bois mountains, and every swell or hollow is distinctly recognisable by the variety of shade, until it is lost in the dark blue of the mountains. Westward the country opens into a vast prairie, which was now animated by the long train of waggons with their linen coverings, winding like a great snake through the high grass towards a spot at the other extremity of the plain where it was proposed to bivouac for the night by the side of a little pond. Thin blue lines of smoke curling up here and there from the woods, betray the dwellings of Indians, and we see their cattle moving about at different points of 
the light groves and prairies. The heavy night dew lies still on leaf and flower, though the sun is already high and draws glittering rays from the drops, which the south-east breeze springing up soon dries away, while it robs the sassafras and millions of flowers and blossoms of their fragrance, and bears it away beyond the mountains. The Texan eagle*, and the white swallow-tailed kite $\dagger$, wheel their flight in great circles through the air, whilst the thrush $\ddagger$ in the shades below tries to blend his song with the melodies of the mocking-bird§, and the parrot, climbing from twig to twig, puts in from time to time a few careless observations.

The traveller is tempted to linger long at this point, for he is now on the frontier of a rich and beautiful country, and will soon find himself in one where his eye will search vainly round the horizon for some spot on which it can rest with pleasure. He bids farewell to the paradise, cuts his name on a crippled oak on the rocky declivity, casts a long lingering glance at the Sugar Loaf now veiled in mist, and then looks about cautiously for the best place to scramble down, leading his mule behind him. When he gets to the bottom he turns his face westward, the woods become lighter, and he soon finds himself on the edge of the prairie, at whose western extremity among some trees he hopes to find his companions with their tents already pitched.

Some of the larger of the prairies, which lie apart from others, are often made the place of rendezvous for thousands of Indians, who come together to carry

* Polybonis vulgaris, Aud.

$\uparrow$ Nauclerus furcatus, L.

† Turdus migratorius, $\mathrm{L}$.

$\S$ Mimus polyglottus. 
on their ancient games, which are coeval with the existence of their tribes, and which will only be forgotten when they perish. No matter how far they may have advanced in civilisation, the Indian gentleman educated in the Eastern States is as ready as the still wild hunter of the same tribe to throw aside all the troublesome restraints of clothing, and painted from head to foot in the fashion of the "good old times," to enter the lists with unrestrained eagerness for a grand national game of ball.

This ball or ring playing is practised more or less among all the North American Indians, and even among the lately discovered Mohawe and Pah-Utah Indians, on the Great Colorado river, it is equally in favour. The ball playing of the Choctaws, Chickasaws, Creeks, and Cherokees, is, however, carried on with such grand formalities, and has such a great charm or "Medicine" ascribed to it, that it deserves more particular mention.

The first occasion for a festival of this kind is generally given by a challenge between two men who have gained a high reputation as ball players. The day is then fixed for the contest, and both parties send out their recruiting officers, painted cavaliers armed with an ornamented ball-stick, and themselves fantastically decorated. They ride on from settlement to settlement, and from house to house, through the whole tribe, announcing to every man the names of the champions and the appointed day, as well as the spot where the contest is to take place, and calling on him to join the side of the player by whom they are sent. Assent is signified by a simple touch of the decorated ball-stick, after which the word is irrevocably pledged. 
Since each champion brings into the field as many men as he can get together, half the nation is sometimes assembled, some to take part in the game, others, and especially the women, to bet. The two parties pitch their tents opposite one another, on the two sides of a prairie adapted to the purpose; and the preparation then goes on. The middle of the ground between the two camps is measured and marked, and 250 paces back from it, each party drives two poles into the ground, six feet from one another, and then connects them by a cross pole sixteen feet long, so as to form a kind of gate; the two gates being placed exactly opposite to one another. Four impartial old men are commissioned to watch the accuracy of the measurements, and they have subsequently to act as umpires. Scarcely has the middle line been drawn, before an eager throng rushes from either camp, to choose their respective antagonists, and begin to bet across the line, every one being quite sure of the victory of his own party, and offering to bet the most valuable article he can afford. The prizes consist of horses, weapons, blankets, articles of clothing, household utensils, in short, of all imaginable chattels, which are brought to the line and placed before the four umpires, who have the duty of watching the valuables the whole night through, and who from time to time manifest their watchfulness by a howling song, to the accompaniment of the Indian drum, or smoke pipes in honour of the Great Spirit, that he may bring the great game to a happy conclusion. The time till sunset is passed by the players, not exactly in dressing, since every article of clothing, except a small apron, is laid aside, but in preparing and adorning themselves. They put on an embroidered girdle with a long streamer 
or tail of coloured horsehair attached to it, round the hips, in such a manner that the tail may flutter out behind; no player is allowed to wear shoes or mocassins of any kind to protect his feet, which, like all the rest of his person, are painted in all imaginable colours ; and except the ball-stick used on the occasion, no weapon or implement whatever must be carried. These sticks are made of light wood, and provided at one end with a ring, large enough to hold the ball, but not to allow it to fall through, for the ball must be touched by no hand.

Accustomed from their childhood to manage these sticks, these people display astonishing dexterity both in flinging the balls to an immense distance, and in catching them as they fly through the air. Only one ball is used in the game, and the possession of this, so as to be able to throw it through the gate of his party, is the object of every one's exertions, for the side which first does this for the hundredth time gains the victory and wins the prizes. As the sun sinks behind the trees, and their shadows fall longer and longer on the grass and then vanish in the twilight, the players advance in long lines with torches towards their respective gates, and dance round them singing, howling, drumming, and playing with and rattling their ball-sticks; the women also advance in procession to the line of demarcation, place themselves in two rows between the gates, and dance and rock themselves and shuffle from one foot to the other on the same spot, raising their voices at the same time in a wild chorus, the umpires sitting at the same time on the frontier line and sending up clouds of tobacco smoke to propitiate the Great Spirit. In this manner the night passes; the 
songs and dances are repeated every half hour, and no other pauses are allowed than such as are necessary to renew their strength for making a noise. The rising sun finds every one in readiness, thousands sometimes waiting for the given signal ; soon a shot is fired, and then one of the "impartial," standing on the frontier line, flings the ball high up into the air. The players instantly rush madly forward and become mingled together in one wild struggling mass of human bodies and limbs in which no individual or group can any longer be distinguished. The turf is trampled into dust, - the crowd sways this way and that, - now one has the ball, but it is immediately torn from his grasp,- the next moment another has snatched it, and it is seen flying through the air towards the goal; but it does not reach it, for it has been arrested in its progress by a watchful eye and a sure hand; the struggle begins again, and at last it is really pushed through one of the gates. A momentary pause follows, and then the ball is again thrown into the centre of the field, and the contest has to be renewed, until it has taken the same course a hundred times; and it is seldom that the end of this rough exciting game is announced before sunset. 
CHAP. V.

FRASER, THE INDIAN SMITH. - SANS-BOIS CREEK. - THE FOUR TRAPPERS. - DR. BIGELOW AND HIS ADVENTURE. - A TRIP ON THE CANADIAN.

As soon as the Pine Grove and the principal heights of the Sans-bois mountains are left behind, the character of the country becomes entirely changed, and only in the bottom lands, or on the banks of small streams, are strips of forest to be seen, and small clumps of trees scattered here and there over the rolling prairie, as the Americans call it. Hitherto you have been travelling through woods interspersed with prairies, now there lie before you prairies varied by occasional patches of wood.

When you come within a few miles of the Sans-bois creek, however, you see signs of a more vigorous vegetation : you come upon fences, corn fields, and herds of cattle, and frequently catch a glimpse through the trees of a log-house. If you follow the road into the forest that forms the broad boarder of the Sans-bois, you will hear, at almost every hour of the day, the strokes of a smith's hammer falling briskly and regularly on the glowing iron and the anvil beneath it, as long as the industrious cheerful smith is able to wield it.

Following the sounds of the forge, you find your way through herds of sleek well fed cows and oxen, who are reposing comfortably across your path, and are not at all inclined to allow themselves to be disturbed in the 
very pleasant occupation of chewing the cud; you come soon to a clearing, and to the paling of a farmyard, in the middle of which rises a rough but well-built loghouse; some Indian children are wallowing about before the door, and a haughty-looking cock is observing their proceedings, while his own large polygamous family is picking up a living about the yard; a cleanly dressed Indian woman is following her domestic occupations, her dark earnest eyes continually turning to her youngest darling, rolling there in the grass; some large dogs are stretched out in the shade of a tree, and would enjoy completely the sweets of idleness, were it not for the trouble of snapping occasionally at a tiresome fly. But unweariedly the mighty hammer continues its strokes, so that the little smithy trembles again, and the bellows draw long deep breaths.

The wayfarer lingers, and almost fears by his entrance to disturb the pretty picture; but at length, tying his horse to the nearest tree, he approaches the paling, and immediately a heap of grunting members of the household, who have been sunning themselves voluptuously on the other side, scuffle snorting away, in their fashion announcing his approach.

The signal of alarm is now given, the dogs spring up and rush at the stranger-the children make for the house-door - the baby turns round curiously in its mother's arms - the hens flutter away into the bushes, and the cock, by an arrogant cackling, expresses his opinion of the intrusion.

Somehow the alarm that has been sounded finds its way into the smithy; bellows and hammer stop, and a sooty Indian advances to the door, - and extending his hand with a friendly "How do you do?" invites the 
stranger to enter his abode, while his assistant, a blue black negro, leaves the fire to take care of itself to welcome the unexpected visit from a white man. In the meantime the train has come up; visitors make their appearance one after another at the little farm, and begin to look about them for eggs, milk, butter, chickens, and such like dainties, for which they gladly pay high prices, and the eyes of the Indian woman sparkle at the sight of the cash, for already in her mind's eye she sees the pretty stuffs and gay ribbands which this unlooked-for windfall will enable her to procure. The Indian smith sells the travellers some head of cattle, a waggon-load of maize, and is even induced without much difficulty to accompany the expedition as guide, as far as Gaines Creek, on the frontier between the lands of the Choctaws and Chickasaws. The conditions of the bargain are soon arranged; the smith washes the soot and ashes from his face, smooths his long black hair - his stout boys saddle him a horse - his wife hands him his coloured hunting shirt, his powderhorn, and shot-pouch - his rifle he takes himself, and after a brief farewell to his family, and some instructions to the negro for the eight days of his absence, mounts his horse, proceeds to the head of the procession, and pursues his way without once looking round.

Our bivouac for the first night of his guidance was to be on the banks of the Sans-bois River, which receives its waters from the mountains of that name, and flows for a considerable time in their vicinity, but it has another source in the angle farther west, where it is joined by the Gaines Creek and the south arm of the Canadian. Flowing then directly towards the east, it 
continues small up to the great turn, where it is joined by the waters of Cooper's Creek, a stream rising near the Canadian, and carries them in a north-easterly direction to the Arkansas. Like all the rivers of that region, the Sans-bois is bordered by land as well adapted to the purposes of the farmer as land can be, its waters are clear and wholesome, flowing mostly over pebbles, and abounding to an extraordinary degree in fish. It is well worth while in the evening to throw in a line while you sit listening to the nocturnal life in the forest, - the loud flapping of the wings of the wild turkey*, as he flutters from bough to bough, seeking his house for the night on the top of some lofty tree, while the white heron $\dagger$ announces his presence by his hoarse cry, and the owl $\ddagger$ utters his hollow shriek. I was busy drawing fish after fish to the bank, but a rustling sound in the bushes near me made me snatch my rifle, which I had lying ready, though only to lay it down again and feel rather ashamed of myself, for I had been alarmed by no more formidable animal than a drake. There is not really the slightest cause for alarm, for the wild Comanche is still far off, and the call of the sentinel from the camp is distinctly audible, - and what a glorious enjoyment there is in this solitude!

When I was completely satisfied with the produce of my line, I packed it together to offer it as a handsome addition to our breakfast in the morning, and in high glee returned through the thicket to the camp, where several members of our party were still sitting up, driving away the mosquitos with tobacco smoke, and

$\ddagger$ Bubo virginianus. 
the time with lively talk: Our evening conversations mostly turned on subjects suggested by our present circumstances, and Indians and trappers formed our principal theme. Every one who had experiences of this kind willingly unpacked his budget, sure of being listened to with attentive ears, and even that some of the auditors would envy his part in such adventures, the condition that they were to have a happy ending being of course understood.

"Civilisation is advancing with rapid strides here," - began one of the group, and whose accent betrayed his German origin,_" there are towns standing now, where thirty years ago you might hunt the black bear and the beaver; to the great grief of the trappers, for they are as much put out by it as the Indians. Two years ago, when I was on the Upper Missouri, near Council Bluffs, I met with one of these half savages; he had grown grey amongst all kinds of hardships and privations, but custom is second nature, and he was attached to his way of life. The stroke of an axe in the forest was a horror to him, and his heart seemed to bleed when he talked of the decrease of the buffaloes in the grassy prairies, and the depopulation of the beaver villages from the country becoming settled. He would talk, with a mixture of pleasure and melancholy, of the time when St. Louis was but a small village, when as yet no steamer had forced its way among the dangerous masses of trees floating down the Mississippi and Missouri, and you would have to make a canoe voyage of months along a tract that you may now pass in a few days. It was in the first days of June, in one of the summers of those happy times, that this old trapper, Pierre, was at St. Louis, preparing for 
a journey with three comrades. All four were what are called free trappers, that is, they were not engaged by any of the great fur companies, but wandered about in the wilderness quite independently, catching beavers, shooting bears, and going once a year down the Missouri or Mississippi, in a boat consisting of two hollowed out trunks of trees lashed together, selling the produce of their hunt at the nearest station, and getting more or less profit according to their previous luck in the chase. These fellows need but little time and little preparation for their long journeys. A horse for each, two pack horses for carrying the ammunition and skins, a small cask of brandy, and a good store of tobacco formed the entire equipment of the four adventurers on this occasion. Each man carried his bed under his saddle in the form of a blanket, and with light hearts the party made their way up the Mississippi, with a view of hunting the otter and beaver in the autumn in the small streams near the Falls of St. Anthony. There were at that time no ferry-boats, much less ferrymen, on the route they were taking, and they often had to cross broad rivers by swimming with the help of some dry trunks of trees. But they were rapidly approaching the Upper Mississippi : they had passed Rock Island; the Prairie du Chien lay behind them; and before the summer was over they found themselves at Lake Pepin. Here they had to adopt a different mode of travelling, for the high rocky shores made their progress on horseback almost impossible; and it was also necessary to make a close examination of the ground, in order to find out whether, on their return in the late autumn, they could set their traps with advantage. In the nearest village of the Chippeway Indians, therefore, they ex- 
changed their horses for a light canoe and some furs. The latter, consisting of valuable otter and beaver skins, took up but little room in their birch-bark canoe, and when, having prudently concealed their small cask of brandy under the skins, the four trappers entered the boat, it had lost but little of its lightness, and yielded to every stroke of the oar. Better rowers or more vigorous arms could not easily have been found, according to Pierre's account. Avoiding the current, and keeping in the still water near the shore, the light canoe flew rapidly under their united exertions towards the Falls of St. Anthony. The mouths of some small rivers were examined without much success, as far as the confluence of the St. Peter with the Mississippi, where they could distinguish the sound of the Great Fall. There they remarked that the course of a small stream coming from the west was checked, and following its shallow bed for a short distance, they discovered some beaver dams, by which the whole of a little valley had been laid under water. Freshly gnawed trees, and still more the beaver dwellings peeping out of the water, informed them that they had now found the place for their autumn hunt. The whole surrounding ground was then carefully investigated, and to the great satisfaction and joy of the party not the slightest trace of a Red Skin discovered in it. In order to give the beaver skins a few months more to grow, the trappers determined to hunt above the falls for that time, and attack the beaver republic on their return. They then dug a round hole in a dry place, placed in it what furs they had, including those obtained from the Chippeways, and also the small cask of brandy, which was intended for the cold autumn nights. The earth they 
had dug out was then cautiously thrown into the water, the little storehouse so closely and skilfully covered with stones and turf that they defied even an Indian to scent out the treasure contained in their cache, as the fur hunters call it.

"Since the whole cargo had been left behind and the hunters had only taken with them what was indispensable, the canoe was still lighter than before; and they succeeded in getting her very near the falls. Here they had to make a portage in order to get round the fall, and in their turn to carry the canoe, which they did until they came to tolerably tranquil water, above the fall, and then launched her again, keeping always close to the western shore in order to avoid the rapids. With the fine beaver village behind them they were now no longer in such great haste, and they regarded the chase in the forest rather in the light of pleasure than business, although a deer's skin was as good as so much money. They had been travelling thus for a few days, though they were not many miles above the fall, when they were one day induced by a sharp appetite to go ashore earlier than usual and indulge in a good broiled venison steak, and a sleep on the grass. Old Pierre and one of his companions undertook the cooking, while the two others took their guns and went out on a ramble to assure themselves of the safety of the neighbourhood. A small fire was soon burning, but of perfectly dry wood, that sent out no smoke to betray their presence. While old Pierre was watching with great complacency the dainty bits which he had stuck upon skewers and placed round the fire, and his companion was with dexterous hand plucking a fine fat turkey, on a sudden a shot was heard at some 
distance. Pierre and his comrade pricked up their ears, but being busy with his cooking, the old man asked the other to climb a tree and take a look round; and the comrade complied with the request, taking his rifle with him, and was soon lost to sight in the thick foliage of a sugar-maple. He had been there but a short time, when he suddenly cried out, in a tone of great alarm, to Pierre, "Save yourself." To seize his rifle, powder-horn, and shot-pouch, and to throw them into the canoe, was the work of a moment, but in the same space of time a party of Indians broke through the thicket and rushed, brandishing their tomahawks, towards Pierre. Giving the canoe a desperate push from the shore and leaping in, he got into the current, but his oars were left behind, a circumstance instantly remarked by the Indians, the four foremost of whom plunged with a yell into the river. The light boat had been carried quickly away, but the Red Skins were still quicker in their pursuit. Every stroke brought them nearer to the helpless little craft ; and the rest of the band on shore already set up a triumphant yell. Pierre now took aim at the nearest and fired, and though he tried to escape by diving, the bullet entered his skull. The savage raised himself a moment high in the water and then sank, leaving a bloody streak on the surface. A howl of rage was heard from the shore, now far off, and echoed by the other three pursuers, two of whom had got near the canoe, and while Pierre was loading again, laid hold of it. There was no time to lose - the trapper seized his knife, and plunged it into his enemy's breast, just below the throat, and the next moment his long deathcry was drowned in the closing waters. This moment, 
however, which had delivered him from one of his foes, was employed by the other in clutching him by the throat, and hanging to it with all his weight. Pierre, whose windpipe was violently compressed, felt his senses going; his arms, on which he was supporting himself to prevent the upsetting of the boat, grew weak, his clenched fist opened and he let go the knife. The canoe swayed on one side, and the savage, still keeping his gripe on his victim, put his naked knee on the edge and was about to throw himself in, when the wet knee slipped and let him back into the water ; for a second he relaxed his grasp, and in that second, with a last exertion of his failing strength, Pierre plunged his knife into him also. There was still one enemy left, but he declined the contest, and turning round made for the shore to announce the fate of his companions; and hoping probably to avenge them by the cruel torture of Pierre's comrades, the trappers whom they had in their power ; while, at the same time, they knew that Pierre, though he had escaped, was without an oar, and driving swiftly towards the falls - that is, to certain destruction. The first thing that Pierre became conscious of was that the dreadfully distorted face of the second Indian whom he had stabbed was gazing at him with glaring eyes. He had seized the side of the boat with such a convulsive grasp that even in death he had not relaxed it, and Pierre had to use the knife again to free the canoe from the hands, and rid himself of the unwelcome presence. But as the waters closed over the last of his foes, the other danger presented itself more vividly to his mind. The falls were now not very distant, and at the rate at which the canoe was going it would soon be upon them; he must leave the boat, or go down with 
it, for to resist the current was impossible. The canoe had been carried over to the opposite shore, and was flying past some projecting rocks, but without touching them. There was only one way of escape possible, and this must be ventured. Watching his opportunity, he threw his powder-horn and shot-belt to a dry place on the rock, and next, as soon as he could, his rifle; but the most difficult task remained, to save himself and reach the shore. Rock followed rock, but no one promised any secure footing, or place that he could lay hold of ; but the thunder of the fall was now distinctly audible, and the leap must be made. As soon therefore as the canoe passed a far projecting, but very steep rock, Pierre set his foot on the narrow edge, and exerting his whole strength sprung as far as he could. The canoe was upset, but Pierre was saved. He was standing up to the hips in water, but the water was still, and with a little trouble he reached the shore.

"He was safe-but where were his friends? Had they all fallen into the cruel hands of the Indians? Might not one at least have found means to save himself as he had done? The river separated him from friends as well as foes, and he could without much danger, make his way back to where the lofty sugarmaple on the opposite shore would point out to him the unlucky camping-place. "This plan he put into execution: he soon found his rifle and his ammunition, and in possession of these he began to move cautiously up the stream. He walked all night, and by dawn of the next day he again saw the high sugar-maple. It was the spot, the embers of the decaying fire had kindled the grass, which glimmered faintly on the bank, the fire still finding nourishment in the dry twigs that 
were lying about. More and more cautiously he crept on, until he came exactly opposite the spot, and there he lay down and listened. All was still and seemingly dead-but presently he thought he would give the well-known signal whistle across the water - and he was answered, but still nothing moved. He then stood upright, so that he could be seen from the opposite shore, and to his astonishment and joy he discovered his comrade, coming down the maple-tree, with his rifle on his back. It was well for him that he had bethought himself to take it with him up the tree, for had he left it below, he would certainly not have escaped the search the Indians would have made. The night he passed among the boughs may not have been among the most agreeable." - " Eleven o'clock!" "All's well!" cried one of the sentinels of our camp - interrupting the story. "Eleven o'clock!" exclaimed the narrator, "and my pipe's out, the mosquitos are biting me too, and though I am not tired, I am lazy. I must finish my story another time, it is too long for to-night." We all rose, stretching and yawning, and with a few remarks upon the fine moonlight, and the prospects of weather for to-morrow, sauntered towards our tents to seek some protection against the heavy dew, and the mosquitos, which were becoming more and more impudent every moment.

Under the guidance of the Indian smith Fraser, we crossed the Sans-bois, and continued our journey along the northern bank. Rocky and wooded hills, fragrant flowery plains watered by bright little rivulets hastening towards the Sans-bois, - these were the features of the landscape, and extremely pretty it was. The deeply hollowed out waggon ruts, however, which at 
the season of heavy rains are turned into so many foaming brooks, permitted us only a slow progress; and the same rushing rains had washed away the earth from the higher parts of this undulating ground, and left exposed loose stones, amongst which our mules could scarcely keep their footing.

In short marches our procession drew near the sources of the Sans-bois, but the almost vertical rays of the burning August sun made travelling in the middle of the day very exhausting; by the afternoon every one was longing intensely for shade and cold water, so that we generally made it a rule to get our creaking train of waggons in motion soon after sunrise, in order to get as much of the day's march done in the early hours as we could. The sandy Canadian River, flowing ten miles to the northward of our route, had not yet been touched upon, and it was therefore agreed among some members of our party to make an excursion to it, if possible at the spot where the Northfork and Southfork fall into it nearly opposite one another. A day on which our party was to make a halt was fixed on for the purpose.

As soon as we were within two days' journey of Gaines Creek, we pitched our camp, with rather more care than usual, in a most lovely little valley, on the borders of a murmuring brook and beneath the shade of lofty unbrageous trees; our white tents gleamed out prettily on the fresh green meadow gay with flowers which extended from our camp to the foot of the neighbouring wood-crowned hills. The mules, freed from their burdens, were grazing in herds, or rolling in the cool soft grass to cleanse their heated and dusty bodies. The human part of the company 
was lying scattered about in groups, talking cheerfully over the little occurrences of the day. All at once, however, it was perceived that Dr. Bigelow, the botanist of the expedition - a general favourite and by far the oldest of the party, was not forthcoming. The aged doctor was a pattern of gentleness and patience, always rejoicing with those that rejoiced, never wanting where a hearty laugh or a good joke was to be heard, quite conscious of his own little eccentricities, and quite willing that others should amuse themselves with them. He was not only a zealous botanist, but also an enthusiastic sportsman, though it must be owned that his exertions in the latter department were not productive of as much profit as in the former, for he had never yet succeeded in bagging anything but a rattlesnake and an old hat. The snake, which had rolled itself up conveniently into a ball, he managed to hit after firing at it only seven times, and his bullet went through the hat in a triumphant manner, somebody having thrown it upon the muzzle of his pistol. To his patients he was most kind and attentive, and of his mule, Billy, he made an absolute spoiled child.

The good old doctor was immediately missed, but there was no cause for any serious anxiety, - and while we were still discussing the matter this way and that, we heard the loud roice of the object of our anxiety, and immediately afterwards he emerged from the thicket driving Billy before him, and dragging an enormous snake behind. "Halloh, Dutchman," he called out (that was the appellation he had thought proper to bestow on the German naturalist) - "Halloh, Dutchman, here's something for you,_ - a splendid specimen of a snake;" and with these words he threw into 
the circle a gigantic rattlesnake of the species with lozenge shape marks, called Diamond rattlesnakes. It was seven feet long, four inches in diameter, and had wide open jaws, armed with a formidable row of poisonous teeth; and since, though it was dead, it showed no trace of a wound, every one was curious to hear the account of the doctor's "fight with the dragon." He told the story as follows :- "After I had collected a rich harvest of ferns at the foot of the mountain, it came into my head that I should like some of the moss off those grey masses of rock for my herbarium. Billy did not seem particularly to wish to go, and I had to get off the poor fellow, and pull him up the hill by the bridle, and he let me pull, and didn't thank me in the least.

"When I got to the top, I was pretty well out of breath, so I thought I would sit down a little while on a block of sandstone ; but the moment I did sit down I heard a kind of rattling sound that I knew the meaning of, and I jumped up again pretty quickly and moved off another way. After I had got Billy into a safe place, I thought I would make out exactly where the rattling fellow was, so $\mathbb{I}$ took my rifle, meaning to aim so as not to hit him and spoil his beautiful skin-I only wanted to frighten him and rout him out_and out he came. When he got out of his hole, he rolled himself up into a knot, and stretched his thick head out in a threatening manner, quivering his forked tongue; so I cut myself a good long stick, and went at him. The first stroke I made I missed him, and he was beginning to show fight, but I whacked away till he could hardly move one of his sixteen rattles. I then tied a string round his neck, for I could not very well ride in his 
company; and as it would have been rather too much to have to pull both him and Billy, I drove Billy on before."

So ended the Doctor's story of his terrific combat with the rattlesnake; and we all gave him honour due for his valour, and informed him of our proposed excursion to the Canadian, which he readily agreed to join.

After a ride of fifteen miles, through marshy lowlands, over gentle slopes adorned with luxuriant vegetation, across rocky ridges on the hard stone of which the ironshod hoofs of our mules sounded like hammers, and where little hares started from the low oak brushwood, our reconnoitring party reached the Canadian at the intended spot, namely, where the Northfork and Southfork join it. The broad sandy bed of the river showed only some narrow shallow runnels of thick-looking water, but from the swiftness with which they ran, it was easy to see that when the water was high this innocent-looking river might assume a very wild aspect. The scene had a dreary desolate character, and though the banks were richly grown with cotton-wood and cedar, no agreeable effect was produced. Trunks of trees, blackened by the effects of the water and of time, lay uprooted and half covered with sand upon the banks, their withered ghostly-looking branches and roots sticking out; here sat the white heron motionless and as if petrified, there the grey bittern; and the vulture wheeled slowly above the almost dry bed of the stream. A shot was fired; but even Echo was silent, and only the heron, disturbed in his gloomy reverie, stretched his scraggy neck, spread his long wings, flew a little way, and then dropped down again and took up 
the same stiff, motionless attitude as before; but the vulture only flapped his wings a few times, and continued sailing round and round as if nothing had happened.

We were all glad to get away from a place that had so little attraction in it; but the sun set when we were still five miles from the camp; and Fraser urged us to hasten our return, though we would willingly have gone in pursuit of some of the wild turkeys that now made their appearance in masses, enlivening every wood, and flew, beating their wings, to the high trees where they sought their nightly rest. There was still a rocky chain to be crossed, the twilight was passing rapidly into darkness, and when we did occasionally see the starry heavens through the openings in the thick foliage, they only served to dazzle us and make the dark shades appear still blacker.

The Indian rode silently on, without slackening for a moment the pace of his horse, and we followed, one after another, quickly up the slopes, and still more quickly down into the ravines. No one wanted to be left behind, on we went rapidly in the darkness along a path that we should have traversed much more cautiously in the daytime; and soon the watchfires of our camp, gleaming in the distance, informed us with what inexplicable exactness the Indian had hit the right direction through the pathless wilderness. 
CHAP. VI.

GAINES CREEK. - THE CREEK INDIANS. - THE CHEROKEE INDIANS.

- THE SHAWNEES. - TEN-SQUA-TA-WAY, THE SHAWNEE PROPHET.

- SHAWNEE TOWN. - FORT EDWARDS. - THE QUAPPA INDIANS. TOPOFKEE CREEK-AND MUSTANG CREEK. - JOHNSON THE SCOUT. - THE EVENING HUNT, - THE FOUR TRAPPERS (CONTINUATION).

GaInes Creen was reached at last, and the Indian smith returned to his forge, so we had to seek another guide. As long as we remained in the country of the Chickasaws, in which we found ourselves after crossing Gaines Creek, there was no difficulty in finding the way; and there was also plenty of choice of camping places; for running streams and gushing springs were sparkling all over among the rich grass of this beautiful country, at least unless where the exuberant climbing plants and wild grapes had absorbed all the moisture and nourishment of the soil to themselves. In this district the Chickasaws and Choctaws live in a peaceable manner together ; for the former, who were originally found more to the south, have come to an amicable agreement with the Choctaws concerning the possession of certain lands, so that it is now often difficult to distinguish one tribe from the other. Their territory extends as far as the Canadian, whilst the paradisaical tract between the Canadian and the Arkansas is occupied by the Creeks or Mus-ko-gees. It is as yet but thinly settled; but well-managed prosperous farms are rising under the hands of the Indians, and the inex- 
haustible fertility of the soil repays the smallest labour with a superabundant harvest.

Not only competence, but even wealth, is to be found among these agricultural tribes; and where but a short time since the painted warrior was endeavouring to express his vague thoughts and wild fancies by hieroglyphical pictures drawn on a tanned buffalo hide, you may now see the civilised Indian reading a newspaper printed in his mother tongue, and an Indian mistress directing the work of her negro slaves - who certainly enjoy milder treatment than she did herself when she was the slave of her lord and master in his savage days.

The Creek Indians, who number about 20,000, formerly inhabited large tracts of the States of Alabama and Mississippi ; but after they ceded their lands to the government of the United States, they moved further to the west, and became the southern neighbours of the Cherokees, the river Arkansas forming the boundary between them. The Cherokees, who are reckoned at 22,000 , were not readily to be induced to quit their extensive lands in the state of Georgia, and abandon the graves of their forefathers. By a former treaty with the United States, they had been recognised as a free and independent nation, with full right to make and administer their own laws; but as it was found that the existence of this separate sovereign state within the limits of Georgia was productive of great inconvenience, the United States Government had since made many attempts to induce them to move westward, and found a new settlement; but all these efforts had been frustrated by the iron will of the Cherokee chief, John Ross, an extremely well educated man, who, in addition to his 
authority as chief, possessed great influence with his nation.

At last, however, a small number of them were induced to migrate to the Upper Arkansas, under the guidance of a chief named Jol-lee; and the accounts they sent back of the beauty and fertility of the new country, united to the persuasions and urgency of the United States Government, had so much effect, that even John Ross finally gave way, and a few years ago followed, with the whole remainder of the nation, in the steps of Jol-lee.

Our passage over Coal Creek was happily effected, and coals for our field smithy obtained; and since the land stretching out to the west appeared, with few interruptions, very flat, the chains of our surveyors were unpacked, and a viameter fixed to the wheel of a small light waggon. The road was smooth, and leading mostly through prairies, brought us nearer and nearer to the Canadian; and after a few marches, we arrived at the first settlement of the Shawnee Indians, which bears the name of Shawnee Village, though there is in reality no village at all, but only some thriving farms of agricultural Indians, lying somewhat closer together than usual, which has probably given occasion to the name, as a similar circumstance has procured for a settlement further on, the appellation of Shawnee Town.

Scarcely was the arrival of the white party made known, than friendly Indians came trooping on horseback and on foot into our camp, bringing with them large quantities of maize, sweet melons, most refreshing water melons, and juicy peaches for sale. Such visitors were of course exceedingly welcome, more especially as 
the deportment both of men and women was remarkably orderly and modest, and they moved about in their cleanly European costume with as much ease and decorum as if they had worn it from their birth.

The regularly featured faces of the men were moreover adorned by a handsome moustache, of which, as of an ornament very rare for an American Indian, they were not a little proud. The women were all what might be called handsome, and the roses visible on their cheeks, despite the dark colour of their skins, spoke of health and cheerfulness. In pleasant quarters does the weary wanderer find himself, when, resting before the cottage of one of these hospitable Indians in the shade of the roughly made protecting corridor, refreshing himself with new milk and fresh bread, or gathering juicy peaches in their cottage gardens, or finding out the water melons hidden in their cool shady bowers. The few families settled in this district appear far more happy and contented than the larger portion of their tribe, who have proceeded northward to the Kansas and the Missouri, and have seen many of their number succomb to their cruel foes, small-pox and brandy.

Of the great and powerful tribe of the Shawnees, or Sha-wa-nos, there are not now left more than 1,400 souls; and the time is not far off when even these few will have become scattered in all directions, and nothing but the memory remain of this once powerful nation.

As neighbours of the Delawares on the coasts of the Atlantic, in the States of New Jersey and Pennsylvania, the Shawnees were among the first who felt the pressure of the victorious civilisation that advanced upon them from the east across the ocean. Many trace the origin of their tribe to the peninsula of Florida, 
grounding their conjecture on the name of the river Su-wa-nee; but it is certain that the Shawnees played a part in the history of the civilisation of Pennsylvania, and that their wigwams stood on the shore of the Delaware and Chesapeake Bay. The Delawares, who had always been their neighbours, fought with them as allies against the common enemy, and marked with the blood of their pursuers the path towards the Alleghany mountains, along which they were driven. Those mountains protected them for a time from their insatiable foes, and for sixty years they maintained themselves in Ohio; but then they had to give way again and move further west, but fighting boldly as they went, till they at last found a permanent home beyond the Mississippi. Still there is now but a poor remnant to be found, and if you ask one of them where is the great brave nation of the Sha-wa-nos, the answer will be, "The graves of our fathers are to be sought by the salt water towards sunrise; then follow the road to the west which is marked by whitening bones, and you will pass over the remains of the brave Shawnees and their fallen enemies."

The chiefs of this people seem to have been without exception great men, and in the struggles of the whites with the Indians, Te-cum-seh, besides being a most dreaded warrior, showed himself the most enlightened and influential politician of his race. His early death probably alone prevented the execution of a deeply laid plan, which had in view nothing less than the burying the war hatchet among the tribes, and uniting the whole race of the aboriginal inhabitants of the North American continent in one common effort against the whites. The history of Te-cum-seh is written in that 
of America, and one scarcely knows whether to regard his being cut off so early as a cause of sorrow or satisfaction.

As a faithful companion, at his side stood his brother Ten-squa-ta-way (the Open Door,) better known under the name of the Shawnee prophet; who undertook, with the help of certain conjurations, to raise among the western tribes a force of warriors who should support Te-cum-seh in his struggle with the whites. The prophet well knew how, by surrounding himself with awe-inspiring mysteries, to produce an effect on the susceptible imaginations of the Indians. Bearing: in his right hand the string of Sacred Beans and the magic fire, and carrying with him also an image of a dead body, the size of life, made out of some light material, he passed from wigwam to wigwam and from tribe to tribe, and his solemn mysterious manner everywhere procured him admission and confidence even among the wild and hostile Indians of the Upper Missouri. Many thousands of them touched the Sacred Beans, and thereby bound themselves by oath to accompany him on his return; and he had kindled the magic fire in many wigwams, whose occupants undertook to guard it with the greatest care from extinction. All was, or seemed to be, so far prepared, that at his return he would have brought his brother quite an army; but fate had ordered it otherwise. Te-cum-seh had fallen, knife and tomahawk in hand, and men of his own tribe, whether bribed by the pale faces or from any other motive is not known, had been following him as he went, and undoing his work by persuading the people that he was insane. He saved his life by flight, but lived ever afterwards in deep obscurity. 
The time which the Shawnees can spare from their farms, they generally employ in hunting expeditions, passing by twos and threes into the territories of the Kiowas and the hostile Comanches, to pursue the shaggy bison and the beautifully marked antelope, and after months of absence to bring back their pack-horses laden with dried meat. Their fondness for the chase and for adventure made it easy for us to find among them a guide, who undertook to conduct our expedition as far as the Old Fort Arbuckle, the present abode of the great Delaware, the Black Beaver. A little stuntedlooking Indian, denominated John Johnson, mounted upon an extremely swift and powerful horse, was engaged in the capacity of scout. He was a crafty hunter, and though he seemed to pursue his way without taking notice of anything, in reality nothing. escaped the keen glance of his little sparkling eyes; he was very taciturn, but it was not so much because he did not understand English, as that he chose to be sparing of his words.

From Shawnee Village to Shawnee Town is a distance of twenty miles ; the way lies near the Canadian River, and is entirely shaded by thick woods. Wild plums and wild cherries peep between the leaves, and an eatable kind of pear grows luxuriantly near the ground, whilst the wild vines wreath themselves round the loftiest trees, and ripen their grapes at their summits in the rays of the almost tropical sun. Between the two settlements on the north side of the Canadian, just at the mouth of "Little River," which reaches it from the north-west, stands an old fortress called Fort Edwards; in which, for a long time, there has been no garrison, and whose barracks the Creek Indians have 
turned into barter-shops and stores, while cattle-breeding and agriculture are carried on, on a large scale in the neighbourhood. A little to the west, on the there high bank of the Canadian, stand still some wigwams or rather log-houses of Quappa Indians, who may boast of not having yet quitted the lands of their forefathers. But they have shrunk to a small band that cannot furnish above twenty-five warriors, and it would scarcely be supposed that they are all who are left of the once powerful tribe of the Arkansas, whose hunting grounds extended from the Canadian to the Mississippi, and who carried on sanguinary and successful warfare with the mighty Chickasaws. It is related that on one occasion a war-party of the Quappaws fell in with a troop of Chickasaws, who, as they had no powder, drew back and avoided the encounter. When the Quappaw chief was informed of the cause of their retreat he called his warriors about him, and desired them to empty their powder-horns on a blanket spread out for the purpose. When they had done so, he divided the stock into two equal halves, and keeping one for themselves, he desired the Chickasaws to come and take the other, and then a furious battle began; in which the Quappaws lost one of their number, but had the satisfaction of hanging up the scalps of eight of their enemies to dry in their wigwams.

Our train of waggons had scarcely left the Canadian at Shawnee Town, to take a south-westerly direction towards Delaware Mount, than a number of small streams flowing towards the south-east had to be crossed. These were the sources of the Boggy, which joins the Red River in Texas, and pours itself with it into the Gulf of Mexico. The banks of the Canadian 
form in this part the dividing watershed between the streams flowing towards the Mississippi on one side and the Gulf of Mexico on the other. Westward of the Delaware Mountains, the Topofkee Creek brings its waters from the shores of the Washita, another tributary of the Red River, and carries them to the Canadian. Near the Delaware Mountains the close woods come to an end, the rolling prairies become more extensive, the river beds drier, and the scattered groups of trees on their banks assume a lighter character. Only in the lowlands, where the water has hollowed out its channel in many windings, can tracts of dark wood be seen, in whose shade the panting wild animals seek a covert. The traveller can now often see the remote blue-green plain and the sunny horizon blending and vanishing into one another, a sight that suggests the vast extent of the Steppes he has soon to traverse. The distances become greater between wood and wood, and water and water, and considerable marches must be made in order to obtain a camping: place with such advantages as can be found in the wilderness.

Lieutenant Whipple's party could move on in these plains, without always being obliged to wait for the surveyors; the prospect was open so far and wide, that distances could be determined by the compass, and the viameter gave an accurate measurement of the number of miles passed, by counting the revolutions of the waggon wheel.

On the 17th of August, we had passed Topofkee Creek and Mustang Creek (tributaries of the Canadian), and were still fifteen miles from the abode of the Black Beaver, when we pitched our camp on the 
edge of a wood, where a spring, gushing out of a sandstone rock, offered us good cool water. The weary company, thickly covered with dust, lay about before their airy tents, and gazed at the evening sun, which now for the first time seemed to sink in the grass of the distant prairie, and shot its red beams up to the zenith, while in the east above a dark wood, up rose the moon and mingled her silver light with the burning rays.

Johnson, the Indian scout, with his six feet long rifle on his shoulder, and carrying the support for the heavy weapon in his hand, approached one of the groups and addressed to them the following speech in his mangled English: "I know many turkey in tree, - a stag at water, turkey sleep_you shoot." One of the party, a hunter, dressed in a full suit of leather, sprung up in an instant, tightened his mocassims on his feet, seized his rifle, and followed Johnson to the wood, into which they both immediately vanished. The Indian crept into the dry bed of a brook, and his comrade followed him closely, treading noiselessly with his soft mocassins on the pebbles, and both stole along silently in the dark shadow of the bank, listening to every sound in the forest. At last the Indian stood still, turned to his comrade, and pointing to a high oak above them, whispered, "Many turkey this tree,_round the tree go when tree stand before moon-you see turkey, Johnson know stag, - Johnson shoot stag white face shoot turkey - turkey sleep."

With these words the Indian crept away, and the thick boughs closed behind him. The white hunter, following the directions given him, moved gently along the bank until he had brought the lofty crown of the 
oak indicated, between him and the moon; and he soon saw first one and then several of the birds sitting upon the gnarled branches of the tree, and only distinguishable from the dark foliage when they were just between him and the silvery disk of the moon. Preparing himself then, he waited the signal shot of the Indian, and listened to the sounds of life in the woods; while the cheerful voices from the camp just reached his ear, the black squirrels sprang fearlessly about him, and where the moonlight gleamed on the bright barrel of his rifle, a merry cricket was clinging fast to it, and making as much noise as if it were trying to outdo a hungry wolf, which from time to time made his howling voice audible from the prairie. Suddenly a shot was heard, and almost at the same moment the hunter's rifle was raised in the direction of the crown of the tree; he fired, and a turkey, dropping from bough to bough, fell heavily to the ground. All was then again still, except that one cock, startled from his perch, but still dead asleep, fluttered about a little and flapped his wings. Again the rifle awakened the echoes of the woods, and this time two turkeys fell to the ground, the one wounded, the other safe and sound, who had tumbled down only from fright. A third fell a victim to the increasing ardour of the white hunter ; and others, who were wagging their heads in a confused and sleepy manner, might have become marks for his rifle, had not Johnson, fetching deep breaths, pushed through the thicket as he was loading again. His shot had not been delivered in vain, for he bore a small Virginian stag upon his shoulders, and now flung it down, panting, to the rest of the game, saying:-

"I shoot one - you shoot three - enough be - to 
the camp go;" and then, without a word more, began with his wood knife to cut down a small sapling and strip away its branches. Having done this, he slung the whole amount of booty to it; and the two, each placing an end of the pole on his shoulders, stepped out hastily back to the camp.

There all was still alive and merry, and the fortunate hunters were heartily welcomed as they threw down their heavy burdens by the watch fire. The prospect of a fresh roast is always an agreeable surprise to a prairie wanderer, and soon everybody was busily en. gaged sticking one or another dainty bit upon a skewer to roast, or broiling it upon the coals, though talking all the time.

"Well, and what became of Pierre the trapper and his three comrades?" asked one at length, while making a determined attack upon a rib of the stag just shot.

"Pierre was standing on one side of the Mississippi, and his comrade on the other," observed a second, holding his savoury morsel fast with his left hand and his teeth, while with his right hand he cut off a bit close to his lips. The storyteller lit his pipe, and blew, in great seeming comfort, a few clouds of the fragrant smoke of the glimmering Schumack and Kine-ke-nik (a kind of tobacco prepared by the Indians from willow bark), and he then proceeded to take up the thread of his interrupted story of the Four Trappers.

"Pierre, as I said then, recognised his comrade, who was standing alone and safe on the opposite shore, and making intelligible signs for him to come over without delay; Pierre pushed a large quid of black tobacco between his teeth, to still the hunger that was beginning 
to torment him, and going a few hundred yards further up the river, rolled up his clothes and his powder-horn into a bundle, fastened this and his rifle upon a kind of little raft made of tough willow branches, lashed together - and then jumped into the river and swam, pushing the raft before him to the opposite shore, where his friend was awaiting him with the greatest impatience.

"When they were once more together, they spent but few words over the occurrence of the past night, being still too anxious concerning the fate of their comrades: if they were still alive, the attempt must be made to get them out of the hands of their enemies, from whom they might certainly expect a torturing death.

"The trapper who had passed the night in the tree, having taken his rifle with him, had escaped discovery, but had been prevented, by the thick foliage of the maple, from obtaining more than a passing glimpse of the wild scene beneath him. When Pierre's canoe and its pursuers had passed beyond the first turn of the river, the rest of the band had loitered slowly along the shore, and from the yells of rage and lamentation that they uttered, when there returned only one of the four who had followed the boat, Pierre's comrade inferred that he had escaped. When the band returned to the spot, they drove their knives furiously into every article belonging to the trappers that they could find about, and wreaked their vengeance even on the oars. Then they kicked the fire about, and yelling, returned to their camp, the smoke of which the trapper, from his airy seat, could perceive at no great distance. He remained in his hiding place the whole night, and a short time before he heard Pierre's signal whistle he 
had perceived that the fierce band had broken up their encampment and moved off. He had answered the signal immediately, but did not venture to stir from his place of concealment till he had perceived Pierre on the shore.

"The two now made their way with the utmost caution towards the previous camping place of the savages, and examined every tree and shrub for indication of the particulars they wished to know.

They made out that their assailants were a party of twelve or fourteen Sioux Indians, that they were on a hunting expedition, and that as they had neither women nor children nor tents with them, their more permanent camp was at no great distance. Their two unfortunate comrades they concluded to be still living ; that one of them was wounded in the right arm, and that, notwithstanding considerable loss of blood, was still able to walk; the other man they believed to be uninjured, but that he had lain bound together hand and foot the whole night; whilst the wounded man had been tied by the left arm to the branch of a tree, so that he could just touch the ground with his feet. Probably they had still four days to live, as there wanted four days to the full moon; the mysterious changes of which planet betray the approach of the Indian Manitoo - and the Manitoo must be the witness of the Indian revenge.

"The savages could be but a few miles in advance, and when the trappers had convinced themselves of their having all left the camp, they followed, cautiously and carefully obliterating their tracks, by a different path, and returning from time to time towards that of the Indians, so as to keep the same direction. In this 
manner they moved slowly and laboriously forward, and the sun was declining by the time a thick wreath of smoke wheeling upward announced the vicinity of the Indians, and warned them to be doubly on their guard. They now made a halt until the sun had gone down, and then describing a wide circuit round the hostile encampment, reached a chain of rocky hills which enclose the narrow valley of a small running stream. On this rocky ridge they could advance without leaving any trace behind them, and they soon reached a spot whence they could completely overlook the camp of their enemies, pitched on a small prairie. The tents were placed on the bank of the rivulet, which here wound through an open space, and the moon and the fire blazing before each tent lighted up a wild and terrible scene. The trappers recognised their two friends bound each with his back against a tree, and every now and then a furious woman would rush at them howling and cursing, and brandishing a knife in a threatening manner close to their faces, whilst others sat wrapt in their blankets near the water and uttered loud doleful cries. The warriors were resting in a circle round a flickering fire, the pipe passing among them, and every now and then one rose to speak-obviously with the view of exciting the angry passions of the rest.

At the very first glance the trappers saw the impossibility of releasing their comrades either by force or stratagem - as things stood at present. There were twelve tents, and twenty warriors besides their wives and children, who kept a vigilant watch over the victims; and even were it possible to cut their bonds that they might escape for the moment, there were horses enough grazing to mount all their enemies; and 
however hard a fight they might make of it, the end was certain.

"A thought occurred to the trappers, however. Was the stream now before them the one at whose mouth they had discovered the beaver village, and had buried their treasures? If so, the spot could not be more than seven or eight miles off, and there was yet a chance for the lives of their poor comrades - that chance lay in their brandy cask. The brandy must be placed within reach of the Red Skins. Pierre and his companion resolved to make the attempt, and going a little way back, they climbed cautiously down into the shallow water, which though at this place a mere trickling thread, sufficed to obliterate their footsteps instantaneously, and also to serve them as a guide. Before the morning dawned they had the joy of discovering the beaver dam; and digging up their cask and strengthening themselves by a deep draught from it, they returned, after a short time given to rest, on their difficult and dangerous errand. They carried the cask and their weapons by turns, and by the next evening they found themselves again at the Indian camp. As Pierre would have infallibly been recognised by the Indians, and his instantaneous death have followed the recognition, it was agreed that his comrade should go alone to the camp with the brandy, while he crept as near as he could, carefully effacing every sign of his progress, replacing every pebble and raising up again every trodden blade of grass, and at last lay still and expectant in a close hiding place among masses of rock and bushes.

"In the meanwhile his comrade had gone by a wide circuit to the old path, into which he turned, and then 
advanced with a firm step openly towards the Indian camp, just as the dusk was coming on.

"His appearance created a great sensation among the savages; but he managed immediately to signify by signs that he had come to exchange fire-water for furs, and this occasioned a short debate among them. Instead, however, of entering upon any barter, they snatched the brandy from him, took away his weapons, and then led him before his captive comrades, who were sufficiently on their guard not to betray, by so much as a glance or a movement of the eyelids, their recognition of him. In order to give themselves up fully to the enjoyment of the much loved fire-water, the suspicious Indians took the precaution to tie the supposed fur trader to the same tree as his suffering comrades, and the one half of the warriors left the camp to search the immediate environs. Some described a circle round the camp, and came so near Pierre's hiding place, that but for the darkness they must have seen some indication of his presence; others had examined the tracks in the forest, but their eager longing for the firewater - a longing almost amounting to frenzy, brought them back before they had discovered the place where Pierre's comrade had turned into their path.

"All the warriors now assembled round the fire, and the cask was opened, the first among them absorbing long draughts of the liquor, while the fiercely eager eyes of the rest watched their mouths with an expression of almost uncontrollable appetite. Very soon this trial of patience was found too severe; the cask was emptied into a large vessel intended for water, and now all could imbibe their ruin at the same time. 
"The women and children, who had at first looked on from a distance, crept nearer and nearer, and were soon crouching behind the insatiable drinkers, their features terribly distorted by the same lust for drink, and impatiently awaiting the moment when the last of the men should lie senseless on the ground, in order to fall on the brandy in their turn.

"The effect of ardent spirits on the Indians is almost instantaneous; and it was a dreadful scene that Pierre witnessed from his concealment. A tumult of yells, insane laughter, furious lamentation broke now on the still evening air, and the secret feelings of malice or ealousy existing among them, but commonly concealed by the close reserve of the Indian character, broke out without restraint, and knives were drawn, and war hatchets hurled, upon one another ; but their arms were now weak and their sight failing, and the murderous weapons either missed their mark or did little damage.

"Then one of them arose, and attempted to go to the prisoners, but staggered and fell before he could reach them, then struggled up again for a moment, and then fell heavily again and lay without sign of life. One after another the drunken wretches lay motionless and helpless on the ground, sometimes with faces convulsively distorted; and scarcely had the last sank into a heavy death-like sleep, than the women and children rushed forward to gratify the same destructive propensity. Even the infants in arms had some of the firewater poured down their throats; and there was a fierce battle for the last drops of the poison over the bodies of the senseless men, a disgusting mass of lifeless and struggling and writhing human limbs. 
"The yelling and howling by degrees became fainter; the bloodshot eyes gazed about vacantly; those who could no longer fight had still not strength to withdraw from the combat, and lay still at last among the hideous heap; the mother suffocating her child; the father with his clenched fist still clutching the knife clotted with the blood of his son or his brother.

"One of the trappers was found to be wounded in the right arm, as his comrades had supposed, having been treacherously attacked from behind; and when he found himself once more at liberty and in possession of his weapons, his first thought was of revenge, and he could with difficulty be restrained by the rest from rushing with his knife on the senseless savages and stabbing them as they lay. But an equally secure and more humane method suggested itself of rendering their enemies innocuous and incapable of pursuit. For at least six hours the trappers would have the start; and there were eight horses ready, four with Indian saddles, and the others as beasts of burden.

"There was, however, no time to lose, and the tents were hastily searched, all the valuable furs collected and fastened on the two pack horses, the two others being destined to carry the skins left at the mouth of the river near the beaver dam.

"The party was soon ready for flight, but there was something more to be done to prevent pursuit. They raked together the nearly extinguished fire till it blazed again, and then threw into it all the saddles, bridles, lassos, and weapons that were to be found ; the trappers even pulling the knives and hatchets from under the senseless human bodies, and giving them to 
the flames. They broke off the triggers of the guns they found loaded, and the powder they could not take with them they scattered about on the ground; and they also allowed their revengeful feelings the gratification of feeding the fire with the cooking utensils of the Indians, and throwing brands into their tents. They then rode off towards the beaver village in a state of great satisfaction, packed their stock of furs on the two led horses, and galloped away down the shore of the Mississippi till they reached a village of Chippeway Indians - who are the sworn enemies of the Siouxes and where they found an opportunity of disposing advantageously of the stolen horses.

"The Chippeways were delighted with the adventure, and afforded the trappers every assistance to embark with their goods in canoes - though they expressed great regret that such a fine opportunity of obtaining a harvest of scalps had been neglected. Amid their exulting congratulations, the four fur hunters embarked in their frail canoes, and reached St. Louis long before they had expected to do so, and with a richer cargo than they had ever yet brought. Old Pierre, however, whose long story I have repeated as faithfully as I could, never again prevailed on himself to return to the Falls of St. Anthony. He could never quite get over his horror of the place, where his head had come so near to forming an acquaintance with the scalping knife.

"My story's at an end now," continued the narrator, "and I shall go to my tent. We shall sleep all the better for that concert the prairie wolves are giving us ; but when we get a few days' journey further, we shall 
have the deep bass voice of the great white wolf, and the yelling jackal for the treble parts. Good night!" And "good night" and "good night" was heard in various directions among the dispersing party, and very soon the profoundest stillness reigned throughout our camp. 


\section{CHAP. VII.}

OLD FORT ARBUCKLE. - THE DELAWARES. - SI-KI-TO-MA-KER, THE DELAWARE CHIEF. - THE ABODE OF THE "BLACK BEAVER." VINCENTI. - THE BLACK BEAVER'S RECOLLECTIONS. - WALNUT CREEK. - PRAHRIE FIRES.

As soon as a streak of light in the east announced the coming day, every man was again on foot and hastening the preparations for departure, and the cool morning air encouraged us to work briskly at striking the tents and packing the waggons; though we did cast some longing glances towards the cook's blazing fire-the boiling coffee and the brown toasted cakes, and the venison steaks hissing in the pan.

The mules, who had been spending the night much to their satisfaction on the rich grass, were quite in a docile humour, and quietly allowed the cold bit to be put upon their hot tongues, and themselves to be harnessed in long teams to the heavy waggons. Johnson, the Indian, mounted on his little horse, placed himself at the head of the procession of equestrians, cast one glance behind him, and then turned into the old scarcely recognisable road that led in a south-westerly direction. In this sunny and yet dewy morning, men and animals moved on cheerfully; even the heavy waggons seemed to bowl along easily on the smooth path, and the cattle that were drawing them appearing unconscious of their weight, amused themselves by looking out for tit-bits 
among the high grass, and cropping them as they went along.

Until noon, a continual rising of the ground was perceptible, but a chain of hills cut off the prospect towards the west, and across these heights lay our road. From thence the eye could range over an immense extent of ground, again bounded in the remote distance by blue mountain masses. At the western end of this sea of grass, and scarcely yet distinguishable, lay the Old Fort Arbuckle, about which a few of the Delawares have settled, and besides their principal occupation, the chase, carry on a little cattle-breeding and agriculture. As we approached it, we saw some herds of cattle lying scattered among the high grass, or moving with slow steps along an old buffalo path that led to the desired shade. This sight inspired our now languid procession with fresh life and spirit, and we all desired ardently to salute the celebrated Black Beaver, not to mention rummaging about in his garden after refreshing melons and peaches.

With these tempting objects before our eyes, little attention was paid to the buffalo paths that now frequently crossed ours, but those who boasted a previous intimacy with the shaggy bison, who had followed him with the rifle, or perhaps leant down from their horses in a wild race and put a pistol to the frightened giant's ribs, could not refuse themselves the pleasure of examining a little more closely the too deeply trampled paths, and looking for fresh traces in the "Buffalo Wallows."

Old Fort, or, as it is sometimes called, Camp Arbuckle, served but a very short time as a residence for a garrison, which was afterwards moved thirty miles 
southward to the new fort of the same name. The abandoned post was then given to a Delaware chief, named Si-ki-to-ma-ker (the Black Beaver), who had done the United States good service in the Mexican war as a hunter and guide. The position was quite in accordance with his wishes; others of his race settled near him, and they now live very happily under the protection of the astute and experienced "Beaver."

The fort itself is such as one might expect to find in these wild regions, consisting of a number of log-houses built in a right angle at the edge of the forest, about a mile from the Canadian, which formerly served as barracks for soldiers; and there is also a separate court surrounded by a high palisade, that is intended as a place of refuge for cattle in case of an attack. Several Delaware families have now taken possession of the abandoned barracks, and are continuing the cultivation of the rice fields laid out by the former garrison. Domestic animals of all kinds increase here without any care, and the thievish Pawnee or Comanche, who should venture to meddle with any of the Delaware possessions, might lay his account with having to a certainty, sooner or later, his scalp hanging out to dry in a peach tree before the door of the Black Beaver; for few as are these descendants of their great and powerful race, the blood and the spirit of their fathers is living in them still, and they are still a terror to their enemies, and faithful self-sacrificing companions to their friends.

The Delaware Indians, who do not now number more than 800 , inhabited originally, to the number of 15,000 , the eastern parts of the States of Pennsylvania, New Jersey and Delaware. Like the Shawnees, they were destined to be continually conquering new hunting 
grounds, only that they might again resign them to the United States Government. Further and further west they were driven, and on every spot where they rested they had first to use their weapons in self-defence against powerful enemies, before they turned them against the wild animals, so as to obtain food and clothing.

Much labour has been expended to bring this tribe within the pale of Christianity, but always in vain. By Christians they had been cheated and betrayed — driven from the graves of their fathers and cut down like wild beasts - and for this reason they have repelled missionaries with displeasure and contempt, considering that as the pioneers of civilisation they would bring in their train the ruin of the legitimate owners of the American continent.

Here, on the extreme frontier of civilisation on the borders of the boundless wilderness, the Delawares can gratify to their hearts' content their love of adventure. They carry their hunting expeditions to the coasts of the Pacific Ocean, and sometimes do not return to their settlements for years together. The long chain of the Rocky Mountains has scarcely a pass through which a troop of these bold hunters has not made its way, nor a spring whose waters they have not tasted. The Delaware fights with the grey bear in California, and pursues the buffalo in the steppes of the Nebrasca; he follows the elk to the sources of the Yellowstone River, and throws the lasso over the maned head of the Mustang in Texas; and it must be added that he does occasionally take a scalp when he can find an opportunity, from a hunter or an enemy's race that he may 
meet with in the desert, or from the midst of a village that has kept insufficient watch.

From the mode of life followed by these people, it is not surprising that very few men are usually to be found in their settlements, and travellers may therefore consider themselves fortunate who are able to engage some of this race as scouts and hunters. Any at all remarkable feature of a country that a Delaware has seen but once in his life, he will recognise again years afterwards, let him approach it from what point he may, and tracts of country that he enters for the first time, he needs only to glance over, in order to declare with certainty in what direction water will be found. If the beasts of burden, so indispensable in this journey, have strayed away during the night, and have been given up for lost by every one else, having left apparently no trace behind, or because hostile Indians make it dangerous to attempt it, the Delaware will not fail to find their track, and will follow them for days or even weeks together, and return at last with the fugitives. These are the qualities that make them so desirable for guides, and their services, upon which the very existence of a whole party of travellers often depends, can hardly be paid too highly.

Si-ki-to-ma-ker, the Black Beaver, and John Bushman, his neighbour, are renowned as guides far and wide; and our expedition, in halting at Fort Arbuckle, had had it in view to use every means to induce one of them to accompany us in that capacity.

As the foremost members of our Expedition crossed the spacious court, where several women and children were basking in the sun, and asked after the Black Beaver, they were shown into the smallest log-house, 
where, under a simple corridor, on a kind of rough wooden settle, an Indian sat cross-legged smoking his pipe, and awaiting his visitors in perfect tranquillity. He was a meagre-looking man of middle size, and his long black hair framed in a face that was clever, but which bore a melancholy expression of sickness and sorrow, though more than forty winters could not have passed over it.

The arrival of visitors did not seem at all to disturb him, and his easy and unembarrassed manner showed that he was quite accustomed to intercourse with the Whites. He spoke fluently English, French, and Spanish, and about eight separate Indian languages; and after the first salutations and expressions of welcome, a tempting offer was made to him to induce him to accompany us. For a moment the eyes of the Indian gleamed with their wonted fire, but they soon became clouded over again, and he answered: "Seven times have I seen the Pacific Ocean at various points; I have accompanied the Americans in three wars, and I have brought home more scalps from my hunting expeditions than one of you could lift. I should like to see the salt water for the eighth time; but I am sick-you offer me more money than has ever been offered to me before but I am sick - I am not likely to want, for my negro can attend to the barter trade, and my relations will help him, but if I die, I should like to be buried by my own people."

No representation that we could make on the subject was of the least avail; the Indian remained steady to his resolution, which arose out of the idea that this journey would be the cause of his death. Apparently, this notion had been put into his head by his wife, who, 
while playing with her only son and a young black bear, frequently addressed to her husband remarks to us unintelligible. It was evident that she did not wish him to go - probably foreseeing that if he once set out he would not very soon return. She dexterously availed herself of his present illness to fill his imagination with so many of her dreams and forebodings that the veteran warrior was quite downhearted and dismal, his spirits had entirely forsaken him, and he made no use of his weapons but for the slaughter of animals for domestic use. Three days were passed in the vain endeavour to restore the Black Beaver to his proper self, and withdraw him from petticoat government; but if in the evening we had succeeded in convincing him that he would be well again and in possession of all his former strength, if he were but restored to his own element, - so that he was more than half resolved to accompany us to the Steppes,-we were sure to find the next morning that he had sunk back into his former fit of obstinacy; and all we could do was to listen to the advice of this sagacious Indian, and make the application of it in due season.

John Bushman, with his little son and a beautiful squaw, paid us a visit in our camp; but it was only to declare how impossible it was for him at present to leave his land. Johnson, the Shawnee too, was now going back to his tribe; so that all that remained for us was to find our way for ourselves as we best might, from wood to wood and from water to water, through the desolate grassy wilderness already on fire in many places.

It happened that by mere accident we met with an interpreter in the person of a little Mexican lad, who, it appeared, would at least be able to hold communication 
for us with any Indian tribes we might meet. Vincenti, or, in better Spanish, Vincente, was a handsome well grown Mexican boy, but with a very artful expression of countenance; he had been for some years in the service of a Creek Indian of the name of Shiasem, who had rewarded him with the present of a horse and free permission to return to his native country. He was perfectly well acquainted with the language of the Comanches and Kaddos, and if the present afforded him a welcome opportunity of going home, his knowledge of languages made him extremely welcome to the Expedition.

Vincente, though he was but fourteen years old, had already seen many remarkable vicissitudes. Of his parents and the home of his infancy, he had but a confused recollection. He had lived in a house where friendly clothed people surrounded him, and they called him Vincente; near the house were trees with fruit, many cows and horses, he used to be able to talk with the people, and there were some of the words they used (Spanish words) which had not yet escaped his memory. At night he used to sleep wrapt in blankets by the side of his mother. On the last night that he passed in that home, he was awakened by a dreadful yell, and he heard the screams of his mother, but she had vanished from his side, and the room was filled with wild painted men, who threw the furniture into the fire to make a blaze. One of the savages caught sight of little Vincente, then about four years old, and snatched him up, but a call from without was answered by a loud howl from within, and they all rushed out of the house and got upon their horses. There was confusion, and terror, and darkness. Vincente felt himself lifted up and placed before one of the riders, the flames at the 
same moment burst out of what had been his home, and by the light of the burning house he saw that a troop of Indians were furiously driving away a herd of cattle.

They rode the whole night through, but in the morning made a short halt, and Vincente had a piece of dried meat and some water given him for breakfast. The journey was continued as fast as the cattle could be got forward, and the little Mexican passed the day on the saddle before his captor, and the night under one blanket with him. They went on thus for many days, until they at last came to the village of the Indians, who, it appeared, were Comanches. Vincente was then stripped entirely naked, and given over to a dreadful looking woman, who placed him among a troop of Indian children, and from this school of savages the boy issued, wholly ruined for a tranquil civilised life.

Eight or nine years passed in this way, and then he was made over in barter from his Comanche owner to Shiasem, who took him with him to the settlements and employed him in various kinds of light service. The bright quick understanding of the boy had enabled him soon to master as much knowledge as could be had among the Creeks, and his good-natured master was now willing to afford him this opportunity of making himself useful as an interpreter, and at the same time of inquiring after his relations in Mexico; but Vincente seemed to rejoice more at the chance of falling in with his old tormentors, and being somehow revenged on them, than of treading again his native soil. That his Indian education had been by no means thrown away upon him may be inferred from his reply when one of us asked him what he would do if the Comanches should 
catch him again. Without a moment's hesitation, he said, "I would greet them as dear old friends; I would win their confidence, and accompany them on their plundering parties. But I would sleep with eyes and ears open, and on the first opportunity I could find I would poison some of them, or stab them in their sleep, and then ride away with their best horses."

With such principles as these it was evidently necessary that the incorrigible little villain should be closely watched; for according to his theory of morals, it appeared perfectly possible that should he see occasion he would betray the whole party of white travellers to the Indians, especially as it would give him a chance of being sung of in their wild melodies as a great warrior.

The time of our sojourn at Fort Arbuckle passed very quickly; some of us made excursions to the neighbouring Delawares, or to the Canadian River, which we were now to lose for awhile, though to meet with again beyond the Antelope Hills; others went about botanising upon its desolate willow-covered banks, or searched about its broad sandy bed for a place deep enough to bathe or fish in with small nets. Some sat in their tents and wrote letters, in order to make use of the last opportunity of sending news to their distant friends; some, who were unwell or who had lost heart, proposed returning with some people who had come to deliver corn for the expedition, that they might revel again in the joys of home and the flesh-pots of Egypt. Now that we were so near the Indian country it was not likely that our hunts would be very productive, and the only game we could find here were horned frogs, and little lizards with steel blue tails. Our people were now practised well in the use of the rifle and revolver, an exercise in which 
little Vincente would gladly have spent every day from morning till night; he too was now fully armed, and soon showed himself one of the best shots of the party, although he could not well use his rifle without a support. Amidst these occupations evening came on unperceived; and then, when all was quiet, the astronomers set to work at their observations of the newly discovered comet, but the rest of the company gathered round the Black Beaver, and endeavoured, by artfully contrived questions, to elicit from him some anecdotes of former days; and when he did begin to tell a story in his simple truthful manner, every one listened with the greatest attention.

"Beaver," said a member of our company one evening, "were not you near when that American captain was murdered by the Indians up there in the Rocky Mountains?"

"Certainly I was," answered Si-ki-to-ma-ker, "and the captain would be alive now if he had followed my advice; but he was wild after hunting, and so was foolish and brought on his own ruin. The last time I saw him alive was at a fort far up in the north in the Rocky Mountains just on the borders of Canada, where the Blackfoot Indians haunt. I had gone there to shoot the grey bear, and to set my beaver traps, and I hoped too, if I should happen to meet with a Blackfoot, to take his scalp.

"The captain used often to go with me on my hunts, but if he could not get a companion he would wander about by himself in pursuit of the elk; there are many of them thereabouts. I had often warned him not to go too far, for I had found fresh tracks of Blackfoots; but he always said he did not care for all the Indians 
in the world put together, and ran about as before. One morning he went out before the other people in the fort were out of their beds, to lie in wait for a black bear that used to come down every morning to the water to drink. He had told us he would be back by dinner-time, but the noon came and he did not come back. Nobody thought any thing of that, for people often don't keep those sort of promises, but when evening came on, and there were still no signs of him, they began to get anxious and sent out men to look for him, but they came back very late at night, and had seen nothing of him. At dawn the next morning they went out again, and I was already a long way from the fort; but though I knew all the captain's favourite haunts, I had great difficulty in finding his trail, as it led along a brook. At last I came to a place where his footsteps were trodden out by the mocassims of the Blackfoots, and then I knew he was no longer living, and all we could do was to find out how he came to his end. I found out that the murderers had been silently following him for a long way, though he had gone on suspecting nothing, and that when he had come out from among the trees into a small open space, so that the Blackfoots had had his whole figure before them, they had shot quite a hail of their sharp arrows at him, and he fell, and before he could make use of his weapons they were torn from him, and wounded as he was, his hands were bound with twigs. The murderers had then robbed him of his boots, and dragged him along with them barefoot, more than two miles; there he must have sunk, for I found his body stripped, lying on its back, with a bullet in the breast, and arrows sticking all about him; 
his scalp was torn off too, but, strangely enough, left lying there by the side of the bloody corpse.

"The Blackfoots had done the business completely, but as they had now had the start for twenty-four hours, it was of no use to think of going after them,-useless and dangerous; so the little garrison could do nothing then but bury the captain's body.

"I left that military post soon after, but I have got many a Blackfoot scalp since. You may see them hanging up painted all of a row, in the wigwam of the Delaware chief on the Kansas. Those scalps there on that tree are from some Pawnees that came here to steal horses. They look very well there, and the birds can play with them."

With these words the Black Beaver sent a cloud of smoke through his nostrils, and looked as if he were talking of quite every day matters, but some of his hearers stared a little at the sick Indian and his warlike trophies.

"What kind of hunting shall we find in the great plains?" asked one of them after a pause. "There's many a creature that you can go after, wanders about those prairies," answered the Black Beaver, "and especially there's the buffalo, countless herds of them; but at this time of year you won't often get an opportunity for a shot at them, as they are all going to the north. They find the sun here too warm for their shaggy hides, and by the time they are driven back by the snow storms in the autumn, you will have crossed the Rocky Mountains, and be in a country where no buffalo has ever grazed. They are shy of this mountain chain, and I never found, but in two places in the neighbourhood of passes, certain signs that the buffaloes had ven- 
tured through to the other side. You may find perhaps a grey old fellow of a bull here or there, but he will not be worth spurring your horse after,-his flesh would be tough, and you could at best only use his tongue."

Turkeys and white-tailed deer* were, according to the Black Beaver, plentiful enpugh by every good water and on the edge of every wood, with which the banks of the tributaries to the Canadian are covered; but we ought, he said, to understand the Delaware way of enticing the deer. If, for instance, we were riding past a wood, we ought, by means of a small pipe, to imitate the cry of the fawn, and the old animal, even though it has parted from its young, will then rush blindly forward to the spot, and become an easy prey to the hunter. Anyone, however, who tries this stratagem had need keep his eyes open, for the prowling panther $\dagger$ and the fierce jaguar $\ddagger$, are just as likely to be attracted by the whistle as the deer, and to come swiftly in long leaps to the place. Their movements are so quick that it is very difficult indeed to send a bullet through their head or their heart, and if only wounded these animals are often extremely dangerous. Antelopes $\S$, the Indian said, we should find everywhere between that place and the Pacific, sometimes singly, sometimes in great herds. They are very swift, and very shy, but also no less curious; and if the hunter knows how to turn this last quality to his own account, the antelope hunt is easy and successful.

For days together these animals will keep going in a circuit round and round the hunter, but never coming

* Cervus virginianus.

$\dagger$ Couguar, or Felis concolor, L.

$\ddagger$ Felis onca. $\$$ Antelope (Dieranoceros) furcifer, Ham. Smith. 
within range of his rifle; he therefore looks out for some shrub or bush, or a few stones in the wide naked plain behind which he can conceal himself, and he then fixes a stick into the ground at a convenient distance for a shot, with a kind of streamer of stuff or leather attached to the top of it, and his patience is seldom put to a long trial. 'The antelopes' curiosity is attracted by the unusual appearance, and they are soon seen advancing towards it, sometimes springing, sometimes walking slowly, and striking the ground with their forefeet as if in defiance, until the hunter manages, by a well-aimed shot, to stretch one on the ground. The others fly in terror, but the shot has made them more curious than ever, and almost as soon as the hunter is ready for their reception there they are again, to lose another of their number. They will often return three or four times before they can make up their minds to avoid the unlucky spot.

"If you can manage," said our Indian instructor, "to rout the Black Bear* out of his den on the Canadian, and to wound him, so that he is inclined to fight, you may have a delightful hunt; you will be pleased with his pluck, and laugh at his comical attitudes; but mind what you are about, and do not let him come too near, or you may buy his hide and his savoury meat a little too dear. But should he retire into his den, then do you make a torch of dry grass or wood, or any thing that will burn, and follow him boldly into his hole, and when the light glares in his eyes, the foolish chap will sit up on end and cover his eyes with his clumsy paws. You then make your torch 
blaze up a bit, and you will see a spot on his breast where the hair grows in a sort of round; you put a bullet in there, and the bear will go down like a Pawnee tent when you have cut the props. One cannot always smoke him out of his den, and even if you do he will sometimes come to the mouth of the cave, dash down, and scrape away the fire with his paws, and go back again.

"The Gold Mountains of New Mexico, which your road will take you past, are full of grey bears*, but don't attempt to attack him unless two or more of you are together. Whoever sees one of these gigantic fellows for the first time may easily lose his self-possession, and if he misses his mark a touch of the claws of his furious antagonist will cure him of his love of sport for ever.

"The swiftness of this animal exceeds that of the horse, and when he is angry he quite loses his venerable appearance. His ears disappear, his little eyes flash fire, and you can see nothing but teeth and glaring eyeballs.

"When I went with some whites through the Rocky Mountains a few years ago," continued our friend the Black Beaver, "I had one of these unexperienced hunters with me, and he swore loud enough that he would attack the first grey bear he could see. He did keep his word, but he thought himself uncommonly lucky to escape with his life, and I will answer for it he will think twice before he attacks such a beast in that thoughtless manner again.

"We had pitched our camp, for the sake of our horses, on a green meadow near the foot of a mountain, where we had about a thousand paces to go to the spring, from

* Ursus ferox, Lewis Clark. 
which we fetched the water for our little cookeries in skins. I had gone to the spring for this purpose with this green young fellow, and was just stooping to catch the trickling stream, when we both suddenly perceived one of these silver grey bears, who, most likely attracted by our horses, was trotting towards the camp. I had no weapon with me, but a horse pistol in my girdle; but my companion had got his rifle, and in spite of my warning he placed himself so as to be able to get a good shot at the bear, who was approaching us from the windward side. I stood by to see what would happen. The shot was fired; the bear shrunk himself together, but the next moment he rushed at the unlucky hunter, who was now running fast enough, overtook him a few steps from where I was standing, threw him down, and instantly tore away the half of his shoulder with his teeth. He was just going to seize him a second time, when I sprang to them, put the muzzle of my pistol to the nape of his neck and, not without danger of wounding the man on the ground, fired. The bear fell dead, and my comrade was saved, but in such a deplorable state that we had to stay in that place for several weeks before he was able to mount his horse."

"Captain Beaver," broke in one of his auditors, "I have seen that even the most experienced hunter may come off short in a scuffle with such an ugly customer as that. Very likely you may know the Canadian, Villandrie, he is the best white hunter on the YellowStone; he is a free trapper, and always will be a free trapper, though the Fur Company at St. Louis have made him the most splendid offers to secure his services. He generally lives among the Siouxes, for he has 
married a woman from among them. One morning, when he was riding out to have a look at his beaver traps, he had to break his way through some thick bushes that grew on a high bank above a small river. He was going along, pushing back the twigs with the barrel of his rifle, and keeping an eye on the bank, when all at once he found himself close to a grey old she bear, who rose instantly and dashed furiously at the horse, as he was struggling with the shrubs and bushes. One blow of her colossal paw was enough to break his back, and to throw Villandrie down the bank, and his rifle into the water. Three half-grown cubs now occupied themselves with the poor struggling horse, while their raging mother rushed towards Villandrie, who was just getting up; but before he had well drawn his long knife, the bear's claws were on his left arm and shoulder. His right arm he could still move freely, and he gave stab after stab in the neck of his fierce enemy, who did not for that relax her gripe, and tried to catch the knife with her teeth. At every movement he made, she seemed to dig deeper into his shoulder and loins.

"The struggle had not lasted a minute, when the sandy bank suddenly gave way, and down the combatants went into the water-fortunately for Villandrie, for the sudden cold bath made the bear let go, she returned to her cubs, and left her mangled antagonist to get away as well as he could. The next day he reached a Sioux village, very much exhausted from loss of blood; but he got his wounds tolerably healed, and is still considered the best white trapper on the Yellow Stone." 
"I know the man well enough," said the Black Beaver; "his body looks as if he had had the smallpox very bad, though he was never ill in his life."

Amidst such talk as this we wiled away the fine summer evenings at Camp Arbuckle ; and we regretted more and more that we were not to have the benefit of the Black Beaver's experience on our journey.

On the 22nd of August, our Expedition left the fort, some of the least magnanimous of our party returning with the corn-dealers towards the east, and the rest turning their faces joyfully in the direction that the sun himself pointed out to them. The Black Beaver gave us the benefit of his escort for the first day, and brought us to a spot where, on close examination, the tracks of old waggon wheels were discovered. It was the path by which, years before this, some Delawares had led Captain Marcy. "Only go straight on along this road," said the Beaver, as he left us, "and you will come to the Rio Grande." Nobody but an Indian, certainly, would have thought of calling it a road, where the eye could distinguish nothing of the kind, and only the softest mocassims permitted a slight ridge in the ground under the thick grass to be felt.

We followed, however, in the direction to which he had pointed, and journeyed on in the neighbourhood of Walnut Creek ; now over far-stretching grassy uplands, now through deep-wooded ravines; it was still the "rolling" prairie that we were travelling on, but the rolling waves had now become mighty billows, and the beds of rustling brooks had changed into deep chasms, at the brink of which we often had to stop and consider how we should get to the other side. Willows 
and oaks shaded the scantily flowing streams; the last kind of tree, especially, is widely diffused over the neighbouring chains of hills, though it is no longer so lofty and vigorous as when it drinks its nourishment from a cool fertile soil, but a low, gnarled trunk that struggles in vain to keep the burning sunbeams from drying up its juices.

The wind, which was from the west, had been all day driving towards us clouds of smoke, which slowly floated before the breeze, or were more rapidly dispersed before a stronger gust. It was evident that as far as we could see from north to south, the prairie was in flames, and the fire was driven rapidly by the increasing wind over the high grass towards the east. Under these circumstances it was necessary to be cxceedingly careful in our choice of a camping place for the night, and we thought we might count on being tolerably safe if we pitched our tents between two ravines not far from one another. These ravines were broad and deep, and their precipitous walls, down which poured several streams of water, were destitute of any vegetation that could offer nourishment to the flames; so that the westerly one might fairly be considered as a natural limit to the advance of the fiery tide. "

Our cattle were driven down into the one lying eastward, to withdraw them from the sight of the fire, and obviate the danger of the panic, terror, and wild flight called a Stampedo; and when they were safely dis. posed of, the greater part of our company betook themselves to the other side in order to watch the fire from the edge of the ravine, and extinguish in time any sparks that might be driven that way. 
Although these fires in the prairies frequently arise from accident, or the carelessness of travelling or hunting Indians, it does sometimes happen that they are intentionally kindled by the inhabitants of the steppes, who burn great tracts of the plains to favour the growth of young vigorous grass. From among the singed stubble, fine blades shoot up in a few days, and the whole surface is soon clothed again in bright green, and has the appearance of a well cultivated cornfield where the young corn is just springing up; and then the Indians proceed thither with their herds of cattle, after they have first kindled a fire in another district.

It is, nevertheless, a matter of no unfrequent occurrence that one of these intentionally kindled fires proves the destruction both of the cattle and of the Indians themselves; for though any one can light the fire, at almost any part of the waving grassy plain, it is often beyond any human power to control it after it is lit, when a storm wind arises to drive it over the boundless surface.

As we sat thus at the edge of the ravine calmly watching the whirling clouds of smoke, and the flames that were now just visible in the distance, or observing the movements of the terrified animals that were hurrying through the high grass and seeking shelter in the ravine, we were suddenly startled by a cry of fire from the camp.

The effect of such a cry upon minds already excited by the scene we had been witnessing may be imagined, for every one knew that not only the success of the expedition, but the lives of those concerned in it, were imperilled by such an accident. We all rushed down to 
the camp, where, through the carelessness of the cooks, the nearest grass had been set on fire, and under the influence of the violent wind, the flames were spreading terrifically. Fortunately, the accident had happened on the east side of the tents and waggons, so that the chief danger was blown away by the wind, while on the other side the prairie fire counteracted the current of air, and approached the camp but slowly. Our whole company now formed a close rank, and following the rapidly spreading fire, stifled the flames by a brisk application of blankets, sacks, and articles of wearing apparel ; and with considerable exertion the danger was at last overcome. Only a spark was to be seen here and there, whilst on the other side of the ravine the conflagration raged unchecked.

The flames had now advanced in a diagonal line to the western edge of the ravine, but the space was too wide for them to cross; the flying sparks went out when they had reached not more than half way, and we were now able to give our undisturbed attention to the majestic phenomenon before us, and watch the fire as it moved across the plain; first, while yet afar off, withering up the tracts of juicy grass before it, and then, at a touch, converting them into ashes.

The night as it came on showed us a sublime picture - a picture that can be adequately described by neither pen nor pencil. The vivid colour of the flames made the sky appear of the most intense black, while they shed a glowing red illumination on the grey clouds of smoke that were rolling away, and changing their hue every moment as the fire was driven before stronger gusts of wind, or nourished by more or less luxuriant vegetation. 
A peculiar disquieting sort of sound accompanies these prairie burnings; it is not thundering, or rushing, or roaring, but something like the distant hollow trembling of the ground when thousands of buffaloes are tearing and trampling over it with their heavy hoofs. It sounded threateningly to us in the camp, and it was with a thrilling kind of admiration we contemplated this awe-inspiring spectacle.

The hunter, accustomed to be on his guard against all chances, when he sees the black clouds of smoke rolling over his head as harbingers of the fiery tide, composedly kindles a new fire in the high grass before him, and having cleared of all combustible matter a spot large enough to ensure his safety, looks calmly from it on the threatened danger passing harmless by. But woe to him who is caught unprepared by a prairie fire, for he will in vain try to save himself by the swiftness of his horse. The tall grass whose ears lash his shoulders, entangle the hoofs of the animal as he flies on his rapid course, and horse and rider become the prey of their terrible enemy.

The red natives of the steppe, who are ready to meet with haughty defiance enemies the most superior in strength, tremble at the thought of the swiftly advancing fire, and the proudest warrior among them will droop his decorated head when you speak of it and whisper, "Do not awaken the anger of the Great Spirit, he is in possession of a terrible Medicine."

On the following morning our Expedition was on its march again in its accustomed order, but it had to journey for hours over the burnt surface, from which the waggon wheels and the stamping hoofs raised up a 
fine black ashy dust, that rendered respiration difficult both to men and horses; the complete calm and the heavy dew that had fallen during the night had quenched, but not altogether extinguished, the conflagration, and light clouds of smoke that ever and anon rose, and then dispersed in the clear atmosphere, betrayed that there were sparks still glimmering which only needed a breath to renew the scene of the previous day, and bring devastation over some yet unconsumed tract of country. The eye accustomed to rest on the pleasant fresh grass, is wearied by the dismal blackish grey of the burnt ground, and seeks in vain for some variety; the flowers have vanished, and the lizards and horned frogs, if alive, do not venture out of their holes. Only numerous skulls of wild animals long since bleached by the wind and now partly blackened by the fire, stare out of the singed stubble with their eyeless sockets, and awaken in the traveller, among other reflections, that of the wonderful productiveness of the chase that from time immemorial has maintained the wild inhabitants of these steppes. Here lay a great buffalo skull with its huge horns still looking formidable, there, among colossal bones, a stately pair of antlers, which time seems to have turned to lime; but the buffalo's shaggy hide is probably hanging on the glossy copper-coloured shoulders of some Comanche, and the stately Virginian stag, and the crafty hunter that pursued him, have both long been dust.

At last we had left dust and ashes behind us, and again went rejoicing on our way through flowers and grass; but the light breeze from the west, at first scarcely perceptible, grew suddenly into a gust, that 
whirling over the plain sent up dust and ashes high into the air, and awakened again the slumbering elementroused it to continue its journey, and once more crackling and smoking, it pursued its devastating round towards the east. Moreover, there now rose also in front of our path, and not far from the foremost of our party, fresh columns of smoke, and this excited a strong and general suspicion that impudent or hostile Indians were endeavouring to hinder our progress. The summer was not far enough advanced for the prairie Indians to burn the grass for the purposes above mentioned, and these fires were the more suspicious as those who had kindled them were nowhere to be seen ; so that their proceeding could not but be ascribed to an unfriendly motive.

The fire advanced very slowly, and occasioned only a short delay; the little rodentia could easily escape from it, but a troop of forked kites and brown falcons had nevertheless hastened thither, and circling sportively about in the black smoke, and watching their opportunity shot down, snatched their frightened prey from before the flames, and carried it off in their sharp claws. Our people soon burnt clear a space amply large enough to contain our whole party, and as the flames approached they were checked by the bald strip, and opening, left us a wide secure passage. Again we were passing through dust and ashes, but not for long, and the far stretching train of waggons was soon moving across the green slopes in the neighbourhood of Walnut Creek, where all the life of the prairie appeared to have taken refuge.

In one ravine the leading stag moved composedly along with a troop of fat deer, and offered himself as a 
convenient target for the hunter, who was following his movements on the high bank. The white wolf was lying down exhausted in the shadow of the single tree, his dry tongue hanging out of his jaws, and gazing, without disturbing himself, at the muzzle of the weapon from which he was about to receive his death. The small groves were alive with families of turkeys; and large prairie hares were crossing the valleys in all directions, and vainly endeavouring, by laying down their long ears, to render themselves invisible. 


\section{CHAP. VIII.}

THE WAEKOW INDIANS. - THE WITCHITAS. - THE KECHIES. - AN ADVENTURE ON THE NEBRASCA. - THE BUFFALO HUNT. - THE BUFFALO. - INDIAN BUFFALO HUNTS. - THE CROSS TIMBERS. FAME ON DEER CREEK. - ENCAMPMENT ON DEER CREEK.

Our airy tents were pitched on the edge of a cool well-watered ravine, and faint and exhausted with the sultry heat of the day and our long ride, we were lying about in groups in the shade, when our attention was attracted by two horsemen, who were advancing over the plain from the west, and directing their course straight towards our camp. In these wild regions one can only expect to meet with Indians, but every one anxiously awaited the arrival of the strangers, who, when they came up, rode at once fearlessly into our circle, leaped nimbly from their strong horses, and shook the hands held out to them in a friendly manner. They were two tall, slender young men, their limbs almost girlishly delicate, so that when you compared the strong bows they carried, with the small hands and slender wrists that had to manœuvre them, you could not help wondering that they should be able to draw the strong sinew and the feathered arrow to the ear. A light woollen blanket was wound round their hips, leaving the upper part of the body entirely bare; they wore leggings and mocassins of soft leather, and a quiver made of rich fur, and filled with poisoned arrows, was 
slung carelessly to their copper-coloured shoulders; their youthful Indian faces were set in a frame of coal black hair, and were not without an expression of subtlety and cunning; red and blue lines were drawn, in Indian artistic style, round their eyes and over their prominent cheek-bones, and their scalp locks were fashionably dressed with coloured feathers.

After they had satisfied their very lively appetites on some, to them unknown, dainties which we offered, and had puffed some tobacco smoke in a dignified manner through their nostrils, Vincente was desired to interrogate them,-a trouble to which the little rascal submitted only with many sighs and groans. He would have liked well enough to have a gossip with the Indians, but translating every word they said, and because he was ordered to do so, he found exceedingly disagreeable, and did not at all hesitate to express himself to that effect.

The newcomers belonged to the tribe of Wakos, or Waekos, neighbours of the Witchita Indians, who live to the east of the Witchita Mountains, in a village situated on the bank of a small river rising in that direction. They were now on a journey to the Canadian, to meet a barter-trader there, but having heard of our Expedition, had turned out of their way to pay us a visit. The Wakos and Witchitas differ only in name, and in some slight varieties of dialect; their villages are built in the same style, and are only about a thousand yards from one another. Their wigwams, of which the Witchitas count forty-two, and the Wakos only twenty, look a good deal like haycocks, and are constructed with pliable poles, eighteen or twenty feet long, driven into the ground in a circle of twenty-five feet diameter ; 
the poles are then bent together and fastened to one another at the top, and the spaces between filled with plaited willow twigs and turf, a low aperture being left for a door, and one above for a chimney. A place is hollowed out in the centre for a fireplace, and round this, and a little raised, are placed the beds of the inhabitants of the hut; which, when covered with good buffalo skins, make tolerable resting-places. Each of these wigwams is generally occupied by two families; and the Wako tribe is reckoned at about two hundred, that of the Witchitas at not less than eight hundred members.

These Indians practise agriculture; and beans, peas, maize, gourds, and melons are seen prospering very well round their villages, though their only agricultural implement is a small rake. With this, they manage to get a little seed into the ground, and the fruitful soil repays the trifling trouble with the most abundant harvests. Scarcely, however, has the melon become eatable, and the cobs of the Indian corn formed, than these thoughtless creatures begin to consume it, and hold feasts that only end when the whole stock has been eaten up, - and then for the rest of the year they have to live as well as they can by the chase. They are skilful buffalo hunters, and, like most of the prairie tribes, shoot their game with arrows from their horses. Those we met had large herds of horses and mules grazing near, the brands on which showed that their lawful owners lived many days' journey off in Southern Texas.

Although our two Indian visitors entered our tents in a very friendly manner, they could not be induced to remain the night with us, though we would gladly have persuaded them to do so, as having missed our way, we should have liked to employ them the following day as 
guides. It may have been an unconquerable tendency to suspicion that led them to decline our offers, or possibly some designs of thievery; for it would have been easy for them to go over the nearest hill, and then come back during the night and catch some of the mules that were scattered about grazing. At any rate, after they left us at sunset, we thought it advisable to keep a particularly good watch, but we were not disturbed.

Shortly before we broke up our camp on the following morning, an Indian of the Kechie tribe made his appearance. These people also live near the Witchita Mountains, and can bring about a hundred warriors into the field. Guided by this new acquaintance, our procession found its way back to the old road, thickly overgrown as it was with grass; and by following it, we found it possible to cross the deep full streams at places where the banks had been formerly cut down and trees felled, so that a passage could now be effected with very little labour. We had, however, to make very short marches, as the path was continually crossed by the small rivers, which, in manifold windings, intersected the lowlands, watering a lovely district that for fertility can hardly be surpassed. Fish of many kinds were sporting in the sparkling streams, and the rays of the sun glittered on the broad mailed backs of numerous turtle. On the heights some wild animals were lying quietly under the shade of seattered oaks, and looking over the waving sea of grass, with its thick border of dark forest, and the winding streams, from which they had been driven by the swarm of mosquitos, who did not venture to follow them to those airy heights, but fell with so much the more fury on all who invaded their dark green shady kingdom below. 
Two horsemen of our party might generally be seen pursuing their march at some distance from the noisy train of waggons, now following the course of a stream, now scrambling down into a ravine, riding over some naked hills, or working their way through shrubs and underwood. This pair consisted of the worthy old Doctor, our botanist, and the German naturalist, with whom he was fond of going on these excursions. An intimate friendship had sprung up between the two; they fished together in various waters, and crawled together through damp chasms and marshes,-the one in search of reptiles, the other of plants,-but they spiced their conversation with many a wrangle nevertheless; the Doctor scolding when the German passed a deer that might certainly have become his prey, to follow some unknown kind of snake; and the German, in his turn, rating the Doctor soundly for shooting at the game a quarter of a mile off, and so just driving it away. The unlucky sportsman would listen very patiently to the lecture, plucking at his grey beard, and modestly suggesting that a quarter of a mile was not too far for a rifle if you kept it at an angle of forty-five degrees. These little differences did not, however, at all interrupt the good understanding between the two; and when the squabble was over, the conversation was generally taken up again just at the point where it had been interrupted. Others of the Expedition were also frequently induced to join them, and listen to the talk and story-telling that went on between them.

"You have been often in these prairies before, friend Dutchman?" said the Doctor one day to his companion.

"Yes," was the reply; "many a hundred mile have 
I travelled in them. I have seen the plains on the Nebrasca under all aspects; when the spring sun was drawing out millions of buds among the herbs and grass, when the hot summer had unfolded them and poured out all sorts of gorgeous colours over them, and when the autumn wind rattled their ripe capsules and bent down their withered stalks; and I have seen them, too, when winter had spread its white shroud over the burnt wilderness, and the snow storm in all its terrors was howling over it."

"Well, I have seen them with the grass and the flowers, and when both were burnt up," said the Doctor. "I went along the Mexican frontier with a surveying party about two years ago. But I don't know how they look in their winter dress. Tell us how you managed to get through the snow storms, and how you fell among the Indians that you lived so long with, and afterwards got back to the whites."

"I will, if you like, Doctor, though I really can't think of that time without a shudder ; but it will be a long story, and you must have patience if you wish to get to the end of it."

"What you can't tell to-day you can tell to-morrow," replied the Doctor. "We shall have to jog on this way a good many days before we get to the Pacific, and our companions here are, I dare say, just as curious as I am."

"Well, we do seem to have a long way before us, with nothing to break it," answered he who was called the Dutchman ; "so if our beasts keep this sort of pace, I will tell you all the wonderful things that happened to me as exactly as I can.

"It was late in the autumn of 1851 that I had to 
return, in company with only one person, across the Rocky Mountains to the Missouri. When we got near the desolate Nebrasca or Flat River, and made our way through herds of buffaloes, the Indians began to play us many ugly tricks, teasing and robbing us, and what was worse, killing one of our horses with a furious blow of a tomahawk. The load that had been carried by four strong horses now fell upon three, - that is on two horses and a mule, - which became so weakened by scanty fodder that they could hardly keep up at all.

"We could now see very well that the first snow storm would deprive us of them, and expose us to the risk of great misery; and so, sure enough, it happened. We dragged ourselves painfully along till we got to Sandy Hill Creek, where it falls into the Big Blue, when an icy gale sprung up from the north, buried us almost in snow, and killed our last horse. We had a small Indian tent that we had bought from a fur hunter at Fort Laramie, some bad buffalo meat, some rice and Indian corn, and with this food we had passed a few days in a very miserable manner; when the Post coming from Fort Kearney to the Flat River passed, and offered to make room for one of us in a little vehicle drawn by six mules, whilst the other should stay in the tent with the goods, and get on as well as he could till the one who went could send back horses for him from the Catholic Mission, which the Post would have to pass, and which lies about eighty or a hundred miles from Sandy Hill Creek. We drew lots, and the lot fell upon me to be left behind in this desolate wilderness, with no other company than that of wolves - who urged by hunger would come round me, I thought, in greater numbers every day, and 
perhaps, when I had grown too weak to offer resistance, fall upon me, and devour me and my leathern tent together.

"When the little conveyance containing the only human beings existing, as far as I knew, for hundreds of miles round, disappeared at last over the wide white waste, my first business was to see that my weapons were in good order, and lay them as ready to hand as I could in my small tent. I had plenty of arms - a double and single rifle, a double-barrelled fowling piece, four pistols, and a six-shot revolver, besides a long knife and a heavy axe; and with these murderous instruments I thought I could maintain my post against a good many savages, should any such undesired visitors present themselves. Being to a certain extent satisfied on this point, I now set to work to defend myself against the increasing cold and the drifting snow, which managed to find an entrance at the minutest openings in the tent leather. I had in no long time raised a wall of firmly stamped snow round my extempore dwelling, and from the neighbouring river dragged a quantity of wood, which I piled up before my low door. A hollow in the ground before my bed of blankets and buffalo hides, served at the same time as a cooking place and a stove.

"I calculated that in fourteen days at furthest I might look for help from the Mission, and I therefore divided my buffalo meat, rice, coffee, \&c. into fourteen days' rations. After having made in this way what preparations I could, I crept in among my blankets and buffalo skins, and managed, as I lay, to stir my fire and get my scanty meat ready, - and then prepared for my first night alone in the great wilderness! 
"With any human creature near, were it but a child, you would not feel so wholly forsaken, and there is comfort in hearing a human voice, were it only a voice of complaint. I was never so forcibly struck with this truth before this evening; and I tried talking to myself, but that did not answer, - your own voice somehow makes you shudder when it reaches no other ear. When the sun set behind masses of snow clouds, and while his last rays were still lingering on the dreary snowy waste, a concert began, which I had heard before, but never found so little to my taste. A troop of prairie wolves broke out into a loud howl, and to their long-drawn treble was soon joined the deep bass of the large grey and white wolf. The wild music was hushed sometimes for a few minutes, and then a solo performer would begin, and make his clear piercing tones heard from afar; then again the full chorus would burst in, the wind carrying the sounds far over the desert. In the ravine where the horses had fallen, and where nothing was now to be seen of them but their polished bones and the iron rings of their harness, a fierce contest arose, and by the shrill sounds of lamentation I guessed that the little prairie wolves had the worst of it, and had been obliged to decamp. I tried for hours together to make out, by their voices, the number of the animals assembled in the ravine, but I could not succeed. It was a melancholy occupation, but it helped me to get through the hours of the black stormy night. At last I fell asleep from exhaustion, and was awakened by hunger when the sun stood high in the heavens.

" ' One night is got through,' I thought, as I cut a notch in one of the tent poles, - 'when the fourteen are 
over, the people will be here.' It was the 16 th or 18 th of November, and I reckoned that by Christmas I might be safe at the Mission. I had no idea how far I was out in my reckoning. The day passed slowly and drearily; I dragged as much wood and water to my tent as I required, but I remarked, to my terror, that my feet felt weak and lame, so that I staggered as I walked like a drunken man.

"I was sitting in a very dull mood before my tent, but as I was hungry, watching eagerly the bubbling up and down of the maize in my boiling kettle, puffing away the while at my little pipe, which I had filled with willow leaves, when I saw some horsemen approaching from the north, driving laden horses before them. Being prepared for all chances, I waited quietly till they came nearer, and then I saw that they were Indians, returning from their beaver hunt to their settlements on the Kansas, and I knew that I had nothing to fear from them. When they had come within gun-shot, one of them began to speak to me in English, and relieved me of every feeling of distrust by declaring himself a Delaware. He was soon sitting by my side in my tent, while his two companions, a couple of wild-looking young fellows, made themselves comfortable in their own way outside. Long and earnestly did he endeavour to persuade me to leave my own and my companion's goods to take their chance with the Indians and the wolves, and go with him to his wigwam on the Missouri. 'The wolves' he said, 'will draw nearer and nearer, and will leave you no rest day nor night; and if the wandering Pawnees find you out, they will plunder you, and scalp you as well.' I declined his offer, and endeavoured to convince him 
that within two weeks, at most, people would come to my assistance with horses; and that I should then be able not only to save all the goods, of which only the smallest part belonged to myself, but also to get some sort of conveyance to perform the journey in - a journey that I feared would be, in my present state, almost impossible for me to make either on foot or on horseback.

" ' You will get no help from the whites,' said the honest Delaware; 'bad horses could not get thus far, and good horses, and their own lives into the bargain, the whites of the Mission will not venture for the sake of a man, that from what your comrade will have told them they will have given up for lost. But I see that a word from a white is more to you than the will and the deed of a Red Skin. You have the choice-may you not deceive yourself.' I persisted in my resolution, though I afterwards most bitterly repented having done so. At parting, the Indian gave me the leg of an antelope as an addition to my small stock of provisions, pressed my hand, and then, without once looking round towards my tent, pursued his journey to the south, and I was once more alone.

"I do not think it would be possible for me to describe the sufferings of the next eight days. I was so lame that I had to crawl on my hands and knees to the water, and back to my tent; my head seemed to whirl like that of a drunken man, and my memory was quite failing me, I believe in consequence of the severe cold. Snow storms howled round the dreary steppe, threatening to bury me and my tent together; and I did not now dare to close my eyes at night for fear of the wolves, for hunger had rendered them bolder, and they were coming nearer and nearer to me. The great white 
ones especially were continually describing circles round my dwelling, howling dismally the while; I heard the snow crackling under their feet, as I lay listening to every sound; and at last I one night saw the teeth of one of them make their appearance through the tent leather. I fired my revolver at random through the thin wall into the darkness, and the fierce brutes fled in terror, but it was only to return in a few hours and renew the attack.

"During the daytime these creatures were not so daring, as they dread the light, and then I ventured to take a little rest. But what kind of rest was it? Among the various properties that made a kind of chaos round me in my narrow dwelling, I had discovered a bottle of laudanum, which, with a case of quinine, formed our travelling medicine chest; and in the morning, after my scanty meal was finished, I used to indulge myself with a good dose, and by that means obtained a sleep of several hours. Gay, pleasant images then surrounded me in my dreams; I felt neither cold nor pain,-I was unconscious and happy. But on awakening, the grim reality again presented itself in all its terrors.

"Nine days I passed in this manner, and cut nine notches in my tent pole to mark them; but when I awakened on the tenth, I felt that my limbs were stiffened and powerless, and I could no longer get in my usual supply of wood and water. My thoughts were overpoweringly gloomy, I completely despaired of being ever rescued from my terrible situation; and without having formed any distinct resolution, or well knowing what I did, I put the laudanum bottle to my lips, and almost emptied it; soon afterwards I fell into a deep kind of swoon, so that I was no longer 
accessible even to dreams. How long I lay in that state I do not know, but when I awoke it was pitch dark, and my tent poles were shaken by a gale that outhowled the wolves. I was tormented by a burning thirst as well as hunger, and having discovered a few glimmering sparks beneath the ashes of my fire, I managed to blow them into a flame, and to moisten my parched lips with some half-melted snow. When the thirst was a little appeased, the hunger began to be more importunate, and in a kind of fury, I seized some of the raw frozen buffalo meat and began to gnaw at it. It tasted deliciously, and without any thought or care for the future, I then toasted piece after piece over the fire, and consumed at least three days' rations. By the morning I felt better,--indeed, the feeling of extreme illness seemed cured at once as by magic; life, even under these conditions, appeared once more sweet; and leaning on my rifle, I tottered out of my tent, and wandered a little about. The exercise had a very beneficial effect, and in a few days I was able to get to the top of a low hill, and look round on the desolate prospect. In spite of scanty food, and the hardships I had to endure, my strength continued to increase; but, unfortunately, my small stock of food decreased in the same proportion, and it was absolutely necessary to think of some method of replenishing it, for it would have been madness now to rely on hope of succour from the Mission. I began to familiarise myself with the thought, that I might have to pass the whole long winter on this spot, and I calculated that even from my enemies, the wolves, I might levy tribute enough to keep myself from starvation.

"Hunger soon drives out feelings of disgust, and it cost me no effort of self-control when I attacked, for 
the first time, their dry, tough, sinewy flesh, and gnawed till I was tired at what strongly resembled the sole of a shoe.

"When I had finished this remarkable meal, and liked it too, I felt quite in spirits, for as I had powder and shot in the greatest abundance, I might also consider that I had a well filled larder. I only needed at sunrise to lift a very little the curtain that covered the opening of my tent, so as to get a view to the banks of the small river, and I was sure before long to have some beast or other come and place himself so that I could send a bullet through his head. I never took more than the best part of the wolf I had killed, but by the next morning there was never more of it left than a few scattered bones, - a fact which convinced me, of what I did not before believe, that these creatures devour their own comrades.

"Slowly and drearily my days passed, and still more slowly the nights; but I was able by degrees to extend my walk a little further, and moreover I could whistle, and even sing, which I exerted myself to do, to keep up my spirits, and also to keep my brains steady, for I must own I occasionally caught them at strange tricks that made me fear I was going out of my senses.

"I had still only cut the sixteenth notch in my pole, when one day, after a very scanty meal, I put my buffalo robe round me, took my rifle under my arm, and set out on my old way to the neighbouring hill. Fresh snow had fallen during the night, completely effacing the tracks I had previously made, and I was slow in working my way to the top, so that by the time I reached it, the sun was declining, and sending slanting rays over the boundless white plain; not a 
breath of air was stirring, and I felt warm in the shaggy buffalo hide, though my breath was frozen in drops like pearls on the black wool that surrounded my face.

"Standing at the top of the hill, I looked round as usual on all sides, and presently discovered, to my great terror, two human forms, which, though they were still a long way off, seemed to be approaching my camp from the north. I say to my terror, for independently of a kind of savage shyness which I had contracted, they came from a region where, I believed, there were none but thievish Pawnees. I considered that if they were Pawnees, it would not be well that they should find me unprepared in my tent; I should do better to await them in the open air, and try and find out their dispositions and intentions, so that I might in the worst case sell my scalp as dearly as possible. I reckoned that I had nearly an hour to make my preparations in, but when they had once reached a point whence they could overlook my small territory, it would be too late to withdraw myself from their sharp eyes. I therefore hastened back to my tent, armed myself with as many weapons as I could carry, and hid the remainder under the bed, after taking out the percussion caps; I then put a good quantity of wood on the glimmering fire, so that a column of smoke might rise through the opening at the top of the tent, and when I left it, took care to walk backwards, and to leave the opening fastened, so as to appear as if it were done from the inside, and that the Pawnees might suppose the occupant to be within and resting by his fire.

"Sandy Hill Creek was only about a hundred and 
fifty paces from the tent, and flowed in a semicircular direction round it; and it had high banks overgrown with shrubs and bushes; thither, therefore, I directed my steps to seek a hiding place. I placed my feet carefully and exactly in the traces that I had left when I went to fetch water in the morning, and these led me to a convenient place on the smooth, glassy surface of the ice, from which the nightly gale had swept all the snow, and drifted it to the high banks. When I got upon the ice, I pulled off what remains of shoes I had on, that the nails in them might not betray me by any scratch; and treading softly, and following the windings of the stream for some time, to diminish, as far as possible, the distance between me and the tent, and yet allow me to see from the other side what was going on, I crawled up the bank between two snow drifts, and placed myself on the edge, so that I could look through the projecting twigs and stalks, and get a clear view without being hindered in the use of my weapons. Long I lay and listened, but the fever of expectation and anxiety prevented my feeling the cold, except that the hand that lay on the barrel of my rifle was almost frozen to it. At last the heads of the two figures I had noticed, rose above the neighbouring hill, and in a few seconds they stood on its summit, and remained for some time gazing on my tent, and talking with one another. I followed with my eyes their slightest gestures, and I could not help a shiver running through me when I saw them throw back their buffalo skins, draw their full quivers before them, and string their bows. Their intentions, therefore, were no longer doubtful; and I saw what I had to expect if they should get the best of it. I was prepared, however, 
and I knew that if they once came within range of my rifle, their lives were mine. I could not let them escape; for if I had, I should to a certainty have had them back in a few days, with a whole troop of their companions. The two Indians soon separated, and making some signs to each other, one proceeded to the hill whence I had first caught sight of them, and began to examine the track I had made, which went straight to the tent; while the other, with his eyes fixed on the ground, made a circuit round it. He examined with great care the track to the water, but appeared satisfied when he had convinced himself that the one line of footsteps lay to, and the other from, the ice. He then noiselessly approached his comrade, who, with his bow in his left hand, and an arrow in his right, was standing before the opening of the tent. No word passed between them, but the last comer raised his finger, and put his right hand on his cheek, and his head a little on one side,-I suppose to signify sleep; he then pointed to the rising smoke, placed his bow before him on the ground, and taking the arrow between his teeth, made with his hands the motion of shooting; after which he took up his bow again, and the two fitted their arrows. Had I been in the tent, nothing could have saved me: I understood their gestures but too well. 'Here lives a man, he is lying by the fire asleep, a few arrows will secure this rich booty ;' these were assuredly their thoughts, and they now placed themselves so that their arrows, shot in quick succession, should meet at a right angle at the empty sleeping place."

"Doctor," cried the narrator, here suddenly interrupting himself, and seizing his companion by the 
shoulder, while he pointed with the other hand to some distant object, "look over that first hill there, and you will see a wood. Run your eye along that dark streak, and at the end of it you will see some black specks, like bushes standing apart, those are buffaloes!" The old Doctor's sportsman-like ardour was aroused in a moment, especially as he saw some horsemen from the front of the cavalcade spring forward and gallop in the direction indicated, where a small herd of buffaloes was quietly reposing in the high grass.

"Hurrah! buffaloes!" exclaimed the eager old gentleman, cocking his rifle, and like his companions, making vigorous use of his spurs. To overtake a herd of frightened buffaloes with mules would, however, not be very possible; and it was therefore determined to approach them unperceived, and get within range under cover of a hill. But each of the twelve or sixteen enthusiastic hunters was animated by a natural desire to be the first to fire a successful shot at this superb game, and each, therefore, endeavoured to push before his comrades. Nobody paid any attention to the wind, or thought of the sharp scent of the shy bison; and when the party at last turned the corner of the wood, they beheld the herd in full flight, about a quarter of a mile off. Everybody looked indignantly at the heavily galloping giants, thundering away, - their short tails with their long tufts stretched out, and trampling the ground beneath them to dust. The Doctor broke silence first by firing off his rifle, and exclaiming: "Well, if I didn't hit the buffaloes, at any rate I fired the first shot;" and a loud laugh, in which the good-natured old gentleman joined with all his heart, was the reward of his facetiousness, as turning their smoking animals, the 
disappointed hunters rode slowly towards the train of waggons, now just visible in the remote distance, and for a long time their talk was only of buffaloes.

Numerous herds of these animals still animate the boundless prairies to the west, and extend their wanderings from Canada to the coasts of the Gulf of Mexico, and from the Missouri to the Rocky Mountains. It is probable that the great mass of them regularly proceed northward in the spring, and in the autumn return to the warmer regions; but a few may be found scraping away the snow from their food near the sources of the Yellow Stone, and even further north; and there are also others that contrive to subsist through the summer in Texas, on the grass, burnt up as it is by the heat of the sun; but these are but few, and usually old bulls, which have been too stiff, or too lazy to follow the black columns of their comrades.

In the months of August and September, the herds, fat, and well fed from the fresh spring herbage, come together in such numbers, that often as far as the eye can reach the plains are blackened with them ; and a rough estimate of their number may be made by calculating the number of square miles they cover. Thousands upon thousands often crowd together in a wild confused mob - the dust rising in clouds from their scraping and stamping hoofs, and the bulls attacking each other, and fighting desperately till their bellowing is heard far off like the sound of distant thunder. At this season a hunter might wander over great tracts of the prairies without finding the track of a single buffalo, and might be tempted to think them entirely deserted unless he should happen to fall in with one of these immense herds, which would bar his way for days 
together. A few weeks, however, bring a change; the great herds disperse in all directions, and again carry animation into the lately desolate solitude of the wilderness. You meet sometimes a single buffalo grazing quietly by himself, and sweeping the ground with his long beard;-sometimes a small group lying on the grass, engaged in the pleasant occupation of chewing the cud; or playing with great agility, and throwing themselves into the most comical attitudes; or going lounging after one another along an old deeply trodden path, which leads to a river, or to some opening in the mountains, where they are most easily passed; or to marshy meadows where they may find old "wallows," or make fresh ones. For this purpose the leading bull will search, with a droll business-like earnestness, in low spots for a place adapted to his views; and when he has found one, kneel down, and begin to rout up the earth with his short thick horns, and then to scrape it away with his feet, until he has made a sort of funnel-shaped hole, in which water soon collects. The creature, tormented by the mosquitoes and the heat, then pushes himself down deeper and deeper into the morass, stamping with his feet, and working his body round and round. When he has revelled in this mud-bath to his heart's content, he does not look like any living thing; his long beard and his shaggy mane have become one huge mass of dripping, clammy mud; and only by his rolling eyes can you recognise in this moving heap of mire what a short time since was a stately buffalo. No sooner has he quitted the pleasant hole, than another takes his place, to resign it afterwards in his turn to a third ; and the operation is repeated by every member of the 
company, until each bears on his huge shoulders a thick muddy plaster, which soon dries into a hard crust, that has to be gradually rubbed off by rolling in the grass, or washed off by heavy rains.

In former days, when the buffalo was a kind of domestic animal among the Indians, no decrease was perceptible in the countless herds; on the contrary, they increased and multiplied in the luxuriant pastures; but when the whites found their way into these regions, the thick soft skin of the buffalo pleased them; they found some parts of its flesh to their taste, and both articles promised to yield abundant profit in civilised countries. In order to obtain them, a desire for the intoxicating and glittering productions of the whites was excited amongst the dwellers in the prairie, and small quantities of these tempting articles offered in return. Then the devastation began; thousands of buffaloes were killed for their tongues only, and still more frequently for their shaggy hides; and in a few years there was an evident falling off in their numbers. The careless Indian never thinks of the future, but lives only for the present and its enjoyments; and he now no longer needs to be urged to the chase, but will pursue this noble animal while there is one left. The time, perhaps, is not far distant when these imposing herds will live only in remembrance, and 300,000 Indians, as well as millions of wolves, deprived of their chief support, and wild with hunger, will become the scourge of the civilised and settled parts of the country.

Buffalo hunting is not only the chief occupation of the prairie Indian, but also his highest enjoyment. Mounted on a swift, strong horse, itself probably but just caught, he can overtake almost any animal that shows 
itself, and delights in sending his deadly arrows among the flying herd while at full gallop.

When the Indian proposes to overtake a herd of buffaloes, he strips himself and his horse of every article that can be dispensed with; leaves saddle and clothing behind, and takes with him only a raw leather thong, forty feet long, which is fastened to the jaws of the horse, and then, being thrown over his neck, drags at its full length behind on the ground. This serves to recover the horse in case of his getting loose by the fall of his rider or any other accident.

The hunter carries his bow, and as many arrows as he can conveniently hold in his left hand, and in his right a heavy whip, by the merciless use of which he urges his horse among the flying herd, and up to the side of a fat cow or young bull. The docile steed soon understands the intention of his rider, and needs no further urging, but places himself near the chosen prey, so as to give the hunter an opportunity of burying his arrow up to the feather in some soft part; but scarcely has the arrow whistled from the bow, and the sharp iron found its way through the curly hide, than the horse springs away as far as he can go, to escape the horns of his now furious enemy, and seek out another victim. Thus the hunt proceeds with the rapidity of a storm wind, until the exhaustion of the horse warns the wild hunter to put some restraint on his ardour. The wounded animals in the meantime have been left by the herd, and are lying exhausted or dying on the route over which the wild hunt thundered but a few minutes before. The wives of the hunters follow in their track, and are soon busily employed in cutting up the game, and conveying the best pieces and the skins to 
their wigwams, where they cut the meat into thin strips, dry it, and tan the skins in their simple manner.

The greater portion of the animals slaughtered is left to the wolves, which are always found in considerable numbers in the train of the buffalo.

The chase is, however, not the only mode in which the Indian carries on his endless war with the buffalo. Another plan is to draw a wolf's skin over his head and the upper part of his body, and go crawling on his hands and knees, pushing his weapon before him, and approach the game in a zig zag line. The long hair that hangs over the buffalo's eyes prevents his being very clear sighted, and as long as his keen olfactory organs give him no warning of the presence of the Indian beneath the disguise, the enemy will often succeed in getting near enough to kill him without disturbing the rest of the herd. Even the sound of a shot does not alarm them, as long as they do not scent a human being; and though many of their number fall, and the death rattle is heard from those who die, it creates no further sensation than that the shaggy heads are turned inquiringly for a moment, and then peaceably continue the pleasant business of grazing.

The poor buffalo is persecuted at all seasons of the year, even when snow storms have drawn a covering over the hollows, and rendered a hunt with horses impracticable. The herd at these times can only work its way slowly through the deep snow; but the Indian has contrived broad plaited snow-shoes, which he fastens to his swift feet, and so skims over the uncertain ground after the laboriously wading giant, and kills the now defenceless animal with the lance. More buffaloes, however, are sacrificed to the uncontrollable passion for the 


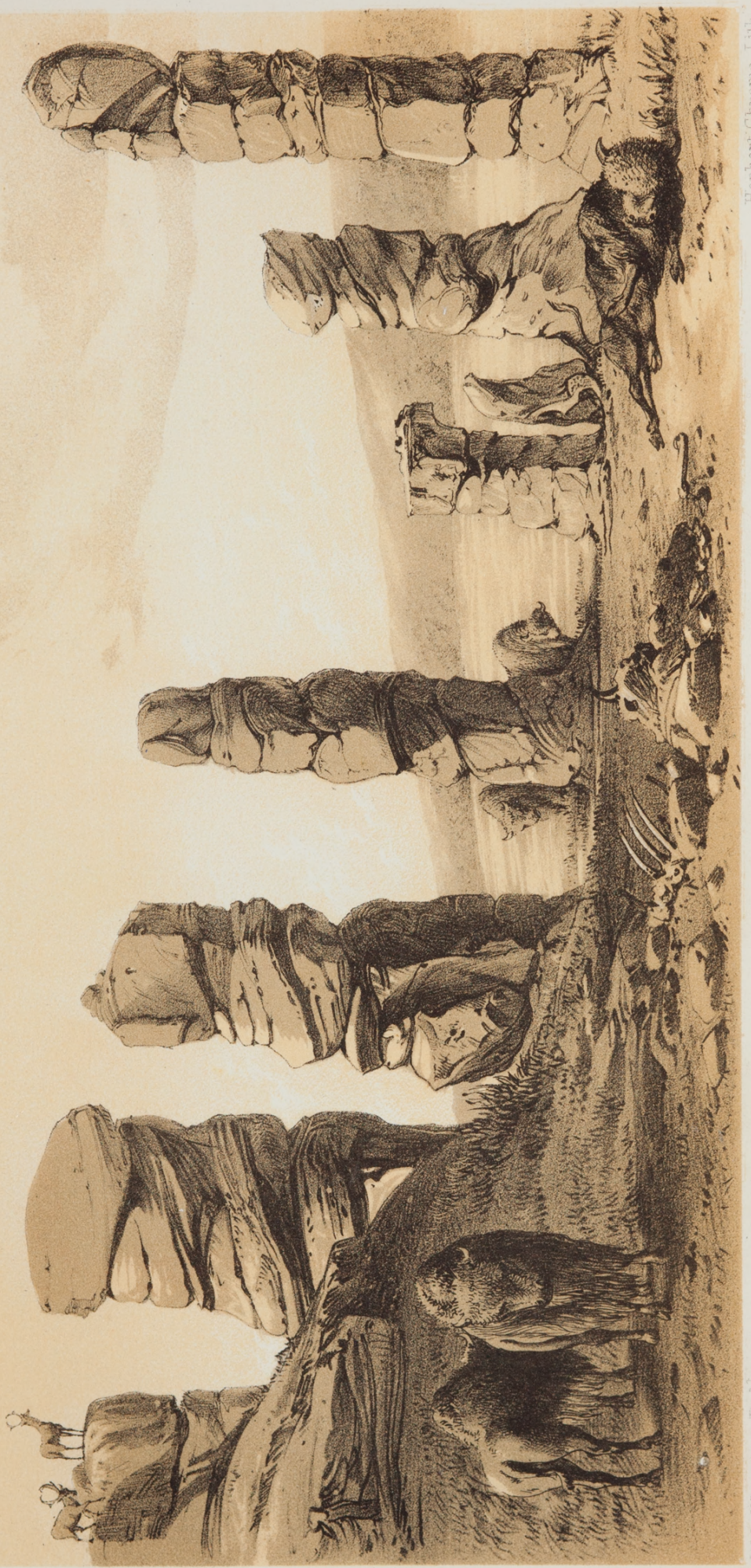



chase than to real necessity, and the war of extermination against this fine ornament of the prairie is carried on in the most unmerciful manner. There will probably be no thought of forbearance till the last buffalo has disappeared, and shortly afterwards, the last red-skin, and with them the only native poetry of the great North American continent.

Wherever Providence has placed living creatures, it has afforded them the means of existence, and in these vast plains, from which civilisation long shrank back, in the belief that they were desolate, there lived thousands of human beings, who had no wish that they were not able to gratify. They lived in plenty, for countless herds of buffaloes were given to them, and to the buffaloes again fat pastures; but the thirst for gain found its way into these solitudes, trampled the glorious works of the Creator into the dust, and will one day look proudly on the roaring locomotive, rushing through the prairie, on its great errand of uniting together the two opposite oceans.

Our would-be buffalo hunters, with the old Doctor at their head, reached the camp at a late hour. It was pitched between the sources of the Walnut Creek and the Deer Creek, and consequently about the middle of the Cross Timbers, the strips of forest that form such a remarkable feature of this region. These strips begin at the Arkansas, and extend in a south-westerly direction to the Brazos, a length of more than 400 miles, with a breadth varying from five to thirty. Throughout their whole extent the Cross Timbers show the same character; the trees are chiefly dwarf oaks, standing with such wide spaces between them, that waggons can drive through with great ease; the 
soil is sandy and barren, and only in the neighbourhood of great rivers, intersected by a few brooks; but wherever they are found, the oaks assume a loftier, more vigorous growth, and also tolerate willows as their neighbours. Where heavy rains have laid bare the ground, you see a reddish loam, crossed by white streaks of gypsum, which broaden as they proceed westward, until they reach the enormous bed of gypsum that begins at Fort Mary and the Natural Mounds.

These Cross Timbers form, to a certain extent, the boundary between the lands adapted for cultivation, and the barren steppe, as well as between the civilised and wild inhabitants ; for eastward of this natural boundary are found numerous brooks and springs, which unite to form small rivers, and then carry their waters to the Canadian or the Witchita, leaving everywhere abundance and blessing behind them. Superb trees of the most luxurious growth mirror themselves in these waters, and flowery meadows of indescribable loveliness border their banks. Westward of the Cross Timbers stretch the great plains in their sublime monotony; no hill there appears to the weary wanderer, at the foot of which he might hope to find a spring ; the wide surface is unbroken, except by isolated fragments, apparently the remains of an ancient plateau, which stand up here and there like pillars, serving the traveller as landmarks, and showing how powerful nature can be in the destructive operations that she carries on through thousands of years. No group of trees affords refreshment to the eye that wanders over this vast space; unless sometimes on the banks of a river, there is no promise of cool shade; the waters that flow over the strata of gypsum are mostly impregnated with bitter 
salts, the few springs that do afford good drinkable water, give but a very scanty supply of their treasure, and the last drop of them is soon sucked in by the sand.

The following day's march brought us to the neighbourhood of Deer Creek; a river that certainly deserves its name, for as our noisy procession approached, fat deer, roused from their slumber among the high grass, were seen breaking from their covert, and bounding away through the many entangling creepers to the river side, to hide themselves in the thick woods. Troops of turkeys were stepping gravely across the open space, or strutting about proudly with their fan-like tails spread out, glittering in the sun with all the colours of the rainbow; but, alarmed by the sound of the waggon wheels, they fled incontinently, with outstretched necks, and hid themselves among the bushes, where nothing but a slight occasional rustle betrayed their presence. Game was now to be had in superfluity; and our long-drawn cavalcade scattered about in all directions, and shots were heard from far and near. Nobody could resist the temptations here offered; the popping went on all the rest of the day, the sportsmen working their way panting through whole fields of mulberry bushes ; and in the evening we lay in groups round the fires, praising the excellence of the fresh game, that speedily vanished before our vigorous appetites, driving away the troublesome insects with clouds of tobacco smoke, and reckoning the various distances that lay between us and our homes. The men talked of their old parents far away - of pleasant evening walks - of the merry games of little sisters and brothers - of their faithful house dogs — of the wild 
gaiety of their negroes, and their monotonous sentimental melodies. Now and then, one would break into a song that he had heard as a child from his black nurse, and then the whole company would join in chorus till the woods and meadows rang with their voices, and the wild concert of the gloomy owls and the thievish cayotas was put to silence. The tree frogs, and crickets, however, took part in the harmony, and the waters of the Deer Creek murmured a running accompaniment to our songs of home. 


\section{CHAP. IX.}

THE ADVENTURE ON THE NEBRASKA (CONTINUED). - THE MIRAGE. - NATURAL MOUNDS AND ROCK MARY.-THE GYPSUM REGION. THE GYPSUM CAVE.-THE DOCTOR'S BEAR HUNT ON THE GILA.THE GREAT PRAIRIE.

The passage of Deer Creek was easily effected, but there was more difficulty with the little streams formed by the numerous springs of this region, which flowed from all directions towards the river, and whose deeply hollowed beds formed serious obstructions in our path.

A general rise of the ground was now perceptible; and since the Cross Timber track was nearly passed, the woods had become more scanty, and a wider view was obtained over the face of the country, which again resembled long rolling waves.

We made a good day's march from the point where Deer Creek is crossed, to the spot where you first catch sight of Rock Mary and the Natural Mounds, a group of bold steep hills in the thenceforward treeless plain. Up to this point no particular change in the character of the scenery is perceptible ; there is the same juicy green in the prairies, the same low gnarled oaks in the woods, the same level road over which waggons and horses proceed at the same steady pace.

"Doctor," called out the German naturalist, as we were jogging along, to his companion who was a little in advance, "if you will ride a little slower, and keep the same pace with me, I'll tell you the rest of my story 
that was interrupted by the buffaloes - that is, of course, if you care to hear it."

"Certainly;" cried the Doctor, with animation, "I know where you left off; " and reining up his mule till the naturalist came up with him, and putting a bunch of flowers that he had been gathering carefully into a leathern bag, he went on, appealing to others who rode up for the correctness of his memory; "you closed the interesting narrative of your most wonderful adventures with saying that the two Indians shot their arrows into the tent, and you sat watching the artful thieves."

"Right; I was sitting on the bank, and peeping between the frost-covered twigs and blades of grass that stuck up out of the snow, at their treacherous tricks. The blood seemed to stand still in my veins, though I could hear my heart beat, as I saw them shoot four or five arrows, one after the other, into the tent; and at that moment I made the discovery how dear life is to man, even in the most dreary and disconsolate circumstances. Nothing stirred behind the thin leathern walls, and the Indians, after listening for a time, cautiously approached the curtained opening. One then laid his bow aside and, seizing his tomahawk, knelt down; whilst the other, with his arrow on the string, stood in readiness to shoot. At this moment the shaven skull of the kneeling man was brought into my line of sight, and I cocked my rifle. Slight as the sound was, they both started, and cast keen glances all round. The kneeling man was now the least dangerous of the two, and I therefore shifted my aim, so that the naked breast of the one with the bow became my mark, and instantly fired. The Indian's sharp eye must have discovered me at the moment, for he sprang aside; but he was hit, and 
fell with a cry that went through every nerve in my body. The other had sprung up, but only to receive the full discharge of buck shot in his face and neck, and to fall lifeless beside his groaning comrade. My enemies were now dead, or incapable of injuring me; but an indescribable feeling of despair seized me, as I thought of what I had done, and of what remained for me to do. I loaded my rifle again, and mechanically approached the bloody spot; and only the groans of the wounded man roused me, and recalled me to myself. It was a horrible sight! There lay prostrate before me, swimming in blood, the two men who a minute before had stood there in the full vigour of life. They had indeed treacherously plotted the destruction of a man who had never done them any injury, never even seen them; and they had fallen a sacrifice to their own greediness for plunder. The body of the younger one lay stretched out, the tomahawk had fallen from his grasp, and the murderous lead had entered his neck and one of his eyes, and frightfully distorted his bronze-coloured face. I turned him on the other side that I might not see it again, and went towards the one who was only wounded. He was an older man; his long black hair almost covered his face, but the fire of deadly hate gleamed at me from his eyes. The bullet had entered the breast below the left shoulder, though whether the wound was mortal or not, I coula not say; but his bleeding, and the clenching of his teeth from pain, awakened the deepest feeling of compassion in me. I bent down over him, and endeavoured to make him understand by signs and single words, that I would drag him into my tent, wash and heal his wounds, cover him with buffalo skins, and take care of him, if I could thereby gain his goodwill. 
At last he made out what I meant, and a wild gleam of joy lighted up his face, as he signified his assent by the Indian exclamation, 'Hau! Hau!' In a moment I felt glad - almost happy again - I should save the sufferer. I should gain a companion and a friend in my dreadful solitude. As I was hastening into my tent, to make what preparation I could for the reception of my patient, his loud groans called me back. He made a sign to me to come nearer, and with a finger of the left hand, he pointed to his right, which was bent in an inconvenient position under his back, and seemed to beg me to draw it out. Without the slightest suspicion, I knelt down beside him, but I had scarcely touched his arm, when the right hand, armed with a knife, flashed like lightning from beneath his body, and seizing me with his left, he stabbed twice at my breast. The blows had been well aimed, but feebly executed. I parried both with my right arm, and snatching with my left the knife which, like the Indians, I wore at my girdle, I plunged it several times into the breast of the revengeful savage. A stream of blood gushed from his mouth; there was a slight rattling sound in his throat, he stretched himself out, and I was again alone - alone in the wide wintry waste - alone with the dead!

"When I rose, I felt the warm blood trickle down my arm, and now first I noticed that I was myself wounded. On drawing back the knife the first time, the sharp blade had passed along the lower part of my arm, and at the second blow the point had struck it almost at the same spot, but only slightly." At these words the narrator turned up the sleeve of his red flannel jacket, and showed the two scars as white marks on his travelbrowned arm. 
"The wounds were but trifling," said the doctor, looking at them with the eye of a connoisseur, "and must have healed better than could have been expected under the circumstances."

"The night that followed this eventful day," pursued the narrator, "was the most dreadful of my life. I really thought I should have gone mad. The two corpses were but a few yards from me as I lay on my bed and cooled my wounds with snow. Of sleep or rest there could be no thought, for the wolves, attracted by the blood, howled dismally round the spot, and would not have suffered me to close my eyes, even if my previous excitement had not made sleep impossible. I fired my pistol continually into the dark night, to keep off the hungry brutes, but besides this, I could do nothing but resign myself to my fate, and await the daylight. With the earliest dawn, however, I hastened out of my tent, to drag away the lifeless remains, and if possible, rid myself of the dangerous company of the wolves.

"It was necessary, too, that I should efface all traces of the Indians, since I could not know whether others of their tribe might not pass that way, in which case the appearance of blood would have immediately decided my fate. I approached the spot therefore, and shuddered to see that the bodies lay in a different place, and were disgustingly mangled by the wolves.

"Hunger drove me to search them, and I found concealed under their leathern girdles some dried buffalo meat, which I took, and then rolling up whatever might have served to betray me with the remains in their buffalo robes, I tied them round, and by great exertion dragged them one after another to the hole in 
the ice, where I got my water, and pushed them under, so that they would be carried away with the current.

"After I had finished this melancholy task, I made such a fire on the place where the two robbers had left their blood, that even the wolves must lose the scent in the heap of ashes, and at night the usual snow storm set in, and effaced the last indications that might have led to a discovery; the hoarse cry of the raven mingled, in the customary way, with the howlings of the wolves, but I had now a feeling of security, as well as a revived hope of rescue, which was increased by the additional supply of food I had obtained.

"Christmas time came, and I had become, to a certain extent, used to loneliness, and managed to do, in a sort of automaton style, what was necessary just to keep myself alive; the wilderness had lost much of its terrors for me, and I thought of the future with a sort of stupid apathy, and sometimes scarcely cared to know what was in store for me, and yet it was no pleasant thought when I sometimes asked myself what would be the end of it. Then my mind ran back sadly over past years, I thought of the Christmases in my native country - in my childhood, of the splendid Christmas trees and the kind friends surrounding me; and lying on my back looking up, when the night was fine, at the glittering starry sky, through the hole at the top of my tent, I inhaled the fragrant smoke produced by mingling some tea with the dry willow leaves in my pipe, the only Christmas indulgence I could afford, and fancied the stars looked kindly down upon me, as they used to do at home, though they seemed, like myself, to be trembling with cold. On the Christmas morning, when I went out into the air, I beheld a flock of prairie 
fowls, sitting among the trees on the banks of the river, and I am ashamed to say how my heart beat, and with what delight, after living so long upon tough wolf's flesh and a scanty diet, I looked forward to the sensual joys of a roast worthy of Christmas.

"I examined my rifle, knowing that these shy birds would not allow me to approach near enough to use small shot.

"A grand looking cock was sitting just within reach of my bullet, but an irresistible, covetous desire to get two birds at once, induced me slightly to change my position. I trod on some dry twig that was hidden by the snow, it snapped under my foot, frightened the fowls, and the whole flock instantly flew off.

"Between hope and disappointment, privation and suffering, the time passed till the first days of January, and I was lying one day under my blankets and skins, neither asleep nor awake, but between the two, when I heard the sound of approaching footsteps, and at the same time the Indian salutation Au-tarro-hau, (Holloa, friend!) I was out of my reverie in a moment, and my hand like lightning on my rifle, when, before I could get out of my tent, came words that sounded like sweetest music to my ears. English words well pronounced - 'You are in a bad case here, friend.' ' Come in,' I cried, almost beside myself with joy, and the curtain rose, and there crawled in, not as I had expected a white beaver hunter, or travelling Mormon, but a very dirty, and very wild looking Indian, pushing a five-foot rifle before him.

"As I made a distrustful, repellent gesture he exclaimed, 'You can speak English with me, I understand very well.' 
"You are an Indian?' I inquired. 'My father was white,' was the answer, 'but my mother was red, and I like better to be an Indian. I belong to the tribe of the Ottoes, and am on my way, with five comrades and our women, from the hunt on the Nebrasca to our wigwams at Council Bluffs. The smoke of your fire drew us here. Our camp is in a deep ravine two miles off, but my companions will soon come up. If you like you shall come into my tent, and go with us to our village on the Missouri. The way is long, and there is a good deal of snow, we must go, for our beasts are laden with meat, but there will be a little room for your things; our women will sew mocassins on your feet, so that you need not leave any bloody trail behind you. Make up your mind, and say what you will, but first give me something to eat, for I am hungry.'

"'I know the Ottoes are brothers of the whites,' I answered, 'I will go with you, however far it may be. As for your hunger I will put my whole stock before you. Here are first two fresh legs of a prairie wolf, not too fat certainly, but if you are hungry you will eat of them; here is a bit of dried buffalo meat, and here is some horse fodder (maize). If you like salt, you need only stretch out your hand to that little bag, it is full of it.' 'Wolf's flesh is bad food,' said Louis Farfar, the half-breed, 'we Red Skins never eat it, but in case of need, or sometimes for a cure, when we have got the toothache or the rheumatism, but give it here, I am hungry.'

"With these words he cut two thin slices from the said legs, laid them upon the fire, and filled up the time till they were ready by chewing the hard, but well-flavoured, buffalo meat. Louis Farfar had not yet finished his 
meal, when two new comers made their appearance, crawling in as he had done, and completely filling up the small dwelling. They were savages; but they stretched out their hands to me in a friendly manner over the fire; and the first, an old wrinkled warrior, whose name was Wo-nes-hee, threw his blanket from his shoulders, drew a bag embroidered with blue beads from his girdle, and set about the important business of smoking, as a sign of perfect good-will. The iron hammer of his war hatchet was hollowed out so as to form a pipe head, from which a thin tube ran up the handle, so that the dangerous weapon served at the same time as a symbol of peace.

"Whilst Wo-nes-hee was taking his mixture of tobacco and Kine-ke-mik (sumach leaves mixed with willow bark), I turned my attention to his younger companion. He was a man of gigantic height, and, as I could see, though he sat crouched together, of fine and powerful form; his hair was cut rather short, and, by great pains bestowed on it, made to stand straight upright, except the plaited scalp lock at the top of his head, which hung low down his back. His face was decorated with black stripes; and in spite of the wild expression of his features, I thought I had never seen a handsomer Indian. His name was Wa-ki-ta-mo-nee, or the Fat Soldier; he was one of the most distinguished warriors of the Ottoes, and the numerous scalps that adorned his shield gave testimony to his valiant deeds, and to his quality of dreaded warrior he added too, as I was informed, that of a great medicine man - that is, physician and conjuror. My unfortunate situation, - especially the wolf's flesh, seemed to awaken a strong feeling of compassion in him; for when old Wo-nes-hee handed the lighted pipe to me, 
he put his hand under the leathern curtain, and pulled into the tent the fresh bleeding quarter of a deer that he had just killed, and with good-natured nods, threw it down at my side. We had now such a feast as I had not known for a long time. Farfar's sharp nose had scented out, among the heap of things tumbled confusedly together, a vessel containing tallow, which we had had for greasing the cart wheels, this he put into the pan to improve the flavour of the fresh venison; and certainly I thought I had never tasted anything more savoury. We ate and smoked, and ate again, and exchanged in the mean time but few either of words or signs, but at every juicy slice that I cut off I blessed my Red-skinned deliverers, who, without any prospect of gain, had said to me: 'You are hungry, eat; you are ready to perish, come with us; you are sick; we will take care of you and clothe you;' and yet, in the eyes of some pious missionaries, they would have been but heathen castaways, not good enough to live with them as menials.

"When we had finished our meal of venison, we made some coffee of roasted corn, once more the pipe of old Wo-nes-hee went round, and then we began to talk of our plan for the journey. It was settled that my Indian friends were to come down in full force the next day, and take me and my goods to their camp, and thenceforward I was to consider their tents as my home, and their hospitable inhabitants as my brothers and faithful companions for life and death. The worthy Red Skins left me towards evening, with a cordial farewell, to return to their camp in the ravine, and I had now but one more night to pass alone in the steppe.

"With what very different feelings I rolled myself this 
night in my accustomed coverings, now that I had had this proof that the kind and watchful care of Providence was still over me, as truly it is in every situation of life; how content and happy I felt that I had not, during this dreadful six weeks, listened to the suggestions of despair. I lay long thinking over the various things that had happened to me; but a few hours since helpless and homeless, and seemingly left to perish, and now I could have shouted aloud at the thought-I was saved and once more to live among human fellow-creatures. I did not know, indeed, how long I might be compelled to remain with savages, but I rejoiced that they were men who seemed, I thought, incapable of treachery, and who looked on me as a brother. And I did feel like a brother to them as long as I remained among them, and up to the moment when I shook their brown hands on our parting, never to meet again, and I saw a sorrowful expression in their bright black eyes. I feel like their brother still, when I stand here, in full health and strength, looking round on the glorious works of God, and remember that I have to thank my faithful Indian friends that I am here do so. I think I shall still have that brotherly feeling towards them when we both appear hereafter to give an account before Him whom these poor savages call the Great Good Spirit.

"By the time the little band of Ottoes came to me on the following morning, I had packed up all the best things belonging partly to myself and partly to my former companion, and I contemplated with the liveliest interest, as they approached to greet me, the other members of the caravan with which I was to be associated. Besides those already mentioned, there were Schin-ges-in-ki-nee, a young warrior; Scha-ho-ka-ta-ho, 


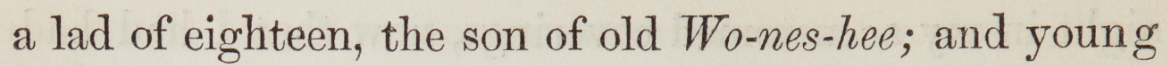
Wa-ki-ta-mo-nee, a fine young fellow, son of the medicine man. A swarm of women followed at a modest distance, and as soon as they arrived, set about packing the bundles that lay about into the half snowed-up waggon which I and my former companion had brought. They left nothing behind, and when the tent leather was found to be too firmly frozen to the ground to be got up, they cut it off above the snow and threw it in with the rest of the things. To what purpose the little waggon was loaded I could not understand, until I saw the women and the young lads harness themselves to it, and by dint of pulling and pushing, with many a merry shout, roll it away in the direction of their camp, while I myself, carrying nothing but my weapons, followed slowly with the elder warriors. When I had reached the top of the hill I stood still a moment to look back on the scene of my indescribable sufferings; all lay still under its white covering, the spot where my tent had stood marked by a heap of ashes, amongst which the embers still glimmered, whilst a light smoke rose from it. There I had passed so many dreadful, sleepless nights; down there, on the bank, I had lain in ambush with my rifle - there the two Indians had fallen, mortally wounded. I looked on my arm where the wounds were scarcely closed, and then at the hole in the ice into which I had pushed the bodies, and a shudder crept over me; but it might be partly from cold, for the lead-coloured clouds hung low down, and some flakes of snow began to fall. I drew my buffalo skins closer round me, and hurried after the rest over the crunching snow."

The story had got on so far, when we turned out of a 
ravine covered with low oak woods, and saw the wide, boundless plain stretching out before us. It was the first time we had seen the horizon line touching and mingling with that of the distant prairie. The far-stretching outline was only broken by the Natural Mounds - a group of hills of a conical shape; which, by the effect of the mirage then prevailing, assumed the most wonderful forms: sometimes seeming to rise out of a broad lake; sometimes to hang down from the bright sunny horizon.

The extraordinary refraction on the horizon of these western regions, soon becomes a familiar phenomenon to the traveller, and long affords him amusement on his lonely path, but it must occasion the torments of Tantalus for him, when he has moistened his tongue with the last drop of warm water from his leathern bottle, and is toiling through the arid waste, knowing that fresh springs and brooks are far behind him.

An expanse of water seems stretched out before him, trees and shrubs crown its banks in the misty distance, reeds rise out of its glassy surface, the whole scene mocks him with the prospect of refreshment and shade. Perhaps an antelope shares his delusion, and hurries in long leaps towards the supposed water, but looks about amazed and terrified when it finds itself still flying over the dry dusty ground. Such a circumstance would help to increase the deception of the wayfarer who should observe him, for the dust raised by his hoofs would be taken for the rippling of water in the lake; but the fantastic forms assumed by the figure of the antelope, would soon, to his disappointment, proclaim the whole scene a mere optical delusion. Scarcely has the animal made the first spring into the deceitful water, than it begins to grow larger 
and larger, until it assumes the proportions of a gigantic buffalo, and then goes on expanding till it loses all definite outline. The middle of the body becomes gradually thinner, the spectral figure is rent asunder, and two images of the animal are seen one above the other; the lower one mostly vanishes first, whilst the upper again assumes more distinctly the form of the antelope, and seems to bend down its neck towards the trees, till lake and woods and reeds all vanish, and nothing is left but the antelope wandering about on the hot dry sand.

The wide plain now lay extended before us, like the ocean in its sublime tranquillity; a few dried-up hollows and rushing streams had still to be passed, but they presented no formidable obstacle to our course; for instead of the former sandy loam, a firm red sandstone lay near the surface of the ground, and had opposed too solid an obstacle to the gnawing tooth of time, and the wild rush of the waters, to allow of the formation of deep ravines, such as are found on the east side of the Cross Timbers. Even this rock, however, had yielded to the influence of thousands of years, and been washed and worn down in particular places; where harder and more impenetrable veins crossed the soft sandstone, the most remarkable forms had arisen, sometimes so distinctly wrought out that you would hardly imagine you had not before you the work of human hands, and of capricious human fancy directing the chisel. Especially striking was the passage from one of the hollows I have mentioned, into a larger one, where, on the smooth sandstone rock stood some formations, appearing at a distance like a number of cupolas, but on a nearer view rather like gigantic urns 
or vases. They were from eight to ten feet high, at the largest parts from four to six feet in diameter, and formed of a deep red sandstone; there was first a broad round foot, then a column, at first slender, but increasing rapidly in circumference, and then, where it attained its greatest breadth, suddenly running to a point, as if to form the cover of the vase. When we had passed this place, our road lay towards the Natural Mounds, which appeared much nearer than they really were, from the perfect level of the steppe.

Mile after mile was passed, and the sun was sinking in the west, when our train of waggons passed Rock Mary to the northward, winding among the hills, westward of which our camp was to be pitched for the night, near a brook whose vicinity had long been manifested by the presence of cotton-wood trees. The Natural Mounds, the chief of which bears the name of Rock Mary, are a chain of conical hills, lying separate, but scattered in a direction from north-west to southeast; they are all about equal in height, namely, about eighty feet, and covered with a horizontal stratum of red sandstone. They appear to be the remains of a former elevated plain, which has been preserved from complete destruction by the upright masses of rock contained in it; and this seems the more probable, because on the flat plain to the west, you find what looks like a range of columns ; consisting of blocks of sandstone lying so regularly one upon another, that it is not easy at first to be convinced that these-not perhaps imposing, but certainly surprising structures, have been formed solely by the hand of nature, or left thus after a comparatively recent convulsion.

There are twelve or fourteen of these columns still 
standing, and more that are gradually being worn away; the largest attain a height of about twenty-five feet; some consisting of vast square blocks of freestone, whilst others, of the same height, have not a diameter of more than two or three feet, and sooner or later will fall.

A spring of water, as clear as crystal, trickled out over a bed of firm sandstone, in the neighbourhood of this colonnade, and was soon swelled into a rivulet by other veins that opened all over the rock, and the rivulet has become a strong though small river by the time it pours itself into the Canadian. This was the boundary between the sweet and the salt waters, and on the following day we entered on the great gypsum region, which passes with reason for the greatest in the North American continent, and is only exceeded in length (according to Darwin) by the great bed of gypsum in Chili, on the Western coast of South America. Where it begins, at the Arkansas, it has a breadth of fifty miles, and it extends in a south-westerly direction across the Canadian to the sources of the Red River, then over a part of the elevated plain, (Llano Estacado, ) touches on the Colorado, and then stretches out beyond the Brazos and Pecos, to a length of at least 400 miles. Wherever, on this tract, the gypsum comes to the surface, it shows itself in every conceivable form : sometimes as white veins, which intersect the red loam in the deeply-hollowed beds of the rivers; sometimes in masses like alabaster lying on the surface of the plain, with such deep openings and chasms, that you can easily go far down into them; and then again as transparent, finely foliated, sparry plates of selenite, of several feet square in surface, and only two inches in thickness, so that it 
would be easy to make large window panes out of them. They are so employed in the towns of the Pueblo Indians, the descendants of the ancient Aztecs, on the Rio Grande, all the apertures for light being closed with them; and these panes have the advantage of allowing the occupants of the house to look out, without it being possible for the keenest eye to see what is passing in the interior of the feebly-lighted rooms. The water of the above-mentioned rivers, which rise in the gypsum region, have always a taste of soda and magnesia, in some places so strong as to make them almost undrinkable, and to produce an evident effect on the health. For this reason, travellers on approaching this desert, make what haste they can across a tract where the sight of cool bright, and yet undrinkable water, is painfully tantalising, when they consider how many a toilsome day's march they have to make through an otherwise waterless prairie.

Our expedition did not, therefore, leave the sweet springs of the Natural Mounds without making the necessary preparations. In order to have recourse as seldom as possible to the bitter water, the skins, and casks carried with us for the purpose, and even the cooking utensils were filled with good water, and when all was ready for our departure, and our horses saddled and watered were standing round, one after another of the party was seen going down to the spring, and taking in such long draughts of the delicious fluid, that they seemed to be quenching their thirst for days and weeks beforehand.

At last our cavalcade got in motion again; the road over the plain was excellent; the Natural Mounds and Rock Mary were left behind in the blue distance, and 
as on the wide ocean, the eye ranged round a circular line, formed by the horizon and the prairie. A sublime repose, indeed, a deathlike stillness reigned around, even the noise of the waggons seemed to die away in the infinite space. The scene was strange and newalmost too new to awaken more than a vague general interest.

The horsemen had left the train of waggons, and rode on confidently over the short grass; there was no more fear of their losing the way, for they must have gone almost a day's journey to get out of sight of their companions; and though some columns of smoke, rising in the west, denoted the presence there of some human beings, they were so far off that no precaution was necessary. A troop of Kiovas or Comanches could not have come nearer than three miles unperceived.

The small swells and inequalities of surface that showed themselves here and there, were almost destitute of vegetation, but glittered all over in the rays of the sun. Many a one of the party was induced to turn his horse that way in order to examine the place, and search for supposed treasures; but on closer investigation they proved to be nothing more than semi-transparent crystalline fragments of gypsum. A troop of these inquiring persons who were pursuing their way, in the eagerness of their talk, at a rather brisker pace than the rest, and had got considerably in advance of the slowlyrolling waggons and their escort of foot soldiers, made a halt upon one of these glittering hills, and alighting from their mules, left them to crop what they could, with only the precaution of leaving the long leathern thongs trailing on the ground, that they might easily catch them again ; and determined to rest, and await 
the arrival of the lost stragglers. The geologist, in the meantime, hammered away lustily at the rocks; the doctor, who was never wanting, instituted a search for plants; the topographer gave himself a great deal of trouble to note down on the chart some variations in the level of the plain; and the German naturalist toiled, in the sweat of his brow, to roll over blocks of gypsum in hopes of discovering snakes and lizards, and transferring them to his spirit bottles. Scarcely had the old doctor reached the top of the hill than he called out, joyfully: "Here! come here, all of ye, the earth is split open here and we can get inside!" We did not let him wait long, and on coming to the spot really found a wide funnelshaped opening in the ground, which, at a depth of twelve feet down, enlarged and showed entrances to low caves and chasms. As soon as the first surprise was over we made preparations to descend. The rough alabaster-like gypsum formation of the walls offered points of support enough for our hands and feet, and in a short time the whole party was below, endeavouring to find an entrance through the low passages into the nearest grottoes; but they were pitch dark within, and the marks of the feet of wild animals were pretty plainly impressed on the soft sand of the floor, so that it did not appear to us quite advisable to thrust ourselves in blindfold. Fortunately, one of us found that he had got with him in his hunting pouch the means of kindling a light, so after a little discussion, another of the party determined to lead the way, and crawled accordingly, with his comrades behind him, on his hands and knees, into the nearest passage, holding the light in one hand, and with the other cautiously pushing forward his revolver. The narrow path soon led to a lofty, spacious 
grotto, whose vaulted roof rested on two irregular pillars; it was very cold, but showed some beautiful and picturesque formations. Here, large masses hung from the roof in the form of stalactites - there, curiously perforated fragments rose from the floor; - in one place the wall was cleft from top to bottom, in another appeared the opening to an inner grotto - not large enough, however, for a man to enter - and at every step made by the explorers some new and interesting phenomenon presented itself, the white rocks glimmering and glittering in the faint light like masses of ice and snow. All the passages opening into this grotto seemed to lead into the open air again, but they were only large enough to allow of the passage of wolves and wild cats, who would certainly have made their way out as we approached. Some of the grottoes we did examine, but without finding any thing remarkable; in one, which had a wide opening, there were some remains of a buffalo, probably one of a herd that had been grazing near, and having approached too closely the dangerous spot, been pushed in by his comrades, and become an easy prey to the wolves.

This subterranean ramble, though quite an unexpected treat, would have been considered more exciting if it had given occasion to a subterranean bear hunt in these dark caves; such, at least, was the declared opinion of the old doctor, when we were all resting in the cool hollow, awaiting in its shade the arrival of. our train. "But dear doctor," said one of the party, "what would you have done if Bruin had really showed himself among us?"

"Why, as a reasonable man, I must of course have killed him," was the Doctor's reply. "You don't know 
how lucky I am in those sort of hunts - now I'll just tell you. Two years ago, when I was out measuring the Mexican frontier, it happened that we had pitched our tent for a long while in the neighbourhood of an old copper mine, and I used to go rambling about every day for the enrichment of my herbarium, though, of course, not unarmed, for neither bears nor Indians are scarce in those regions; but as my revolver was too heavy I used to content myself with a small pocket pistol. A young man belonging to the Commission, who was almost as good a sportsman as I was myself, took it into his head one day to arm himself with his rifle and accompany me. Well, we went along talking and botanising, and crawling in and out of places, and just when we least expected it, we found ourselves in a bear hunt. We had worked our way through a bit of thicket, and come out upon a small clear space, when, you may just fancy our fright, not twenty paces off us, there was an old black she-bear. She was standing on her hind feet near a great tree, with her ears laid back and showing all her teeth. Her little sharp sparkling eyes turned now on us, and now on the thickest part of the tree, where a young bear sat hunched up in a comical attitude on a bough. This was the reason why she did not like to leave the spot, but contented herself with growling defiance. We were ashamed to turn back, and besides I could not help thinking how I should like to tame that little shaggy chap; and my companion, as he afterwards confessed to me, had already tasted in imagination of the good ham we might get from the old one. We had soon made our arrangements; my comrade took aim with his rifle at the head of our grim enemy, and I held my pistol so that the bullet should go right into her 
heart, and then we fired. No sooner was the crack heard than the bear made two springs towards us snarling dreadfully, but the young one tumbled heels over head out of the tree upon the ground, and then the mamma jumped back to pick him up, and disappeared with him into the wood. My comrade and I looked after her very much astonished, and tried to laugh away our fears; but we did not trouble ourselves to follow her trail, but trotted away to our camp as fast as we could. It was certainly a piece of foolhardiness to attack the bear; but nothing could have been more lucky than our missing her, for if we had wounded the monster we should not have got off for the fright only." We all heartily agreed with the old Doctor, and extolled his valour to the skies, and this remarkable illustration of it put the party into a humour for wild merriment. We laughed and shouted and sung, to the no small astonishment of some others of our party who now came up, and who found the mules grazing without riders, and when they rode round the little hill heard laughter and singing proceeding from the interior. The game of hide and seek did not last long, however; the new comers had soon found the entrance to our lower world, and lent a helping hand to the adventurers climbing up again into the light of day, and who did not fail to reward their services with accounts of the wonderful and terrible adventures they had met with in the enchanted gardens below.

The journey through this gypsum region lasted five days : towards the end of the time the want of good water was much felt, and every one had to quench his thirst with a bitter draught. Unfortunately it was found not only that the thirst became more troublesome than 
ever, but a general feeling of indisposition prevailed throughout the party, and the food, which seemed also affected by a disagreeable flavour, became quite distasteful to us. Under these circumstances it will not seem surprising that much of our accustomed good humour and cheerfulness disappeared, and that we jogged along, with as much patience as we could, but in a very dull mood.

When we got to within two days' journey of the Antelope hills, the land of the gypsum region, and at the same time the boundary between northern Texas and the lands of the Indians, the formation appeared to be undergoing a change, for the small elevations were no longer covered with fragments of gypsum, but with fossil oyster-shells. This continued, however, only for a short time, and then the plain resumed its former character.

The mules and the small herd of cattle we had with us were well content, for the salt taste of the water was to them an agreeable condiment, and the grass was plentiful though not high. Scantily watered as the district was, we could manage every evening to reach a brook, which offered sufficient for our necessities, while our cattle found food on its banks. All these streams, including the most considerable of them, the Gypsum Creek, hastened in various windings to the Witchita and Canadian. They were swarming with fish of many species, amongst which we particularly distinguished the Chaetodon rostratus, armed with its tremendous row of teeth; this creature appeared to share the dominion of the waters with the soft-shelled coriaceous turtle. 
The Kioway Indians hunt these regions, but the boundary between their grounds and those of their western neighbours, the Comanches, is not determined. The great tribes of the Comanches and Kioways live on a friendly footing with one another, and extend their ravages and their hunting expeditions from the settlements of the Shawnees to the Rio Grande, and from the Nebraska or Flat River to the colonies on the Mexican Gulf. 


\section{CHAP. X.}

THE ANTElope HILLS. - THE PRAIRIE DOG. - ADVENTURE ON THE NEBRASKA (CONTINUED). - GRAPES. - THE COMANCHE INDIANS. WILD HORSES, OR MUSTANGS. - ACCIDENT TO THE GERMAN NATURALIST.

We reached the Canadian at last; and at the moment when its broad mirror was first spread out before us, we caught in the blue distance a glimpse of the misty Antelope hills. They vanished again from our sight however, when, in order to get to the river bank, we descended between some wild hills into the valley.

A great change took place in the aspect of the river as we approached it. The dull brick-coloured fluid moved slowly through its broad bed, scarcely covering the sand that it rolled along. The holes that we scraped, to get water for drinking, were immediately sanded up again, and a few drops were sufficient to inform us that the waters of the Canadian, which at a lower part of its course were fit for every purpose, were here as unpleasant as that of any of the salt streams that paid tribute to it. We redoubled our haste, therefore, to get to the Antelope hills, that when we had reached their western declivity we might revel once more in the pure element of which we had so long been deprived.

The Antelope or Boundary Hills are six table-shaped. 
elevations, rising 150 feet above the plain ; their form is regular, in some oval, in others round; they look like gigantic ramparts, are all covered by a horizontal stratum or table of white sandstone, eighteen feet thick, and are without doubt the remains of elevated plateaus, which here rise in so remarkable a manner above the boundless plain. Each of these ramparts may be ascended at certain parts, and when you stand on the platform and look round, your view is bounded only by the blending line of the horizon and the grassy plain. How grand and calm, how sublime and yet how oppressive, is the prospect!

Strips of stunted wood peep out here and there in the ravines or on river banks, but they wear the same uniform tint of green. Far as the eye can reach all is green, with the exception of some red spots on the northern bank of the Canadian, places where the heavy rains have washed away the vegetable soil, and left the red sandstone and the white veins intersecting it, exposed to view. The brick-dustcoloured river itself comes from the west, and describing a great semicircle towards the north, flows on again in an easterly direction.

The way led for a time between hills, westward of which we came out upon a level plain, where the character of the country suddenly changed. We found short but rich buffalo grass, and shallow ponds or pools, some of which contained very good water; and prairie dogs also made their appearance. Many of the ponds and old river beds were quite dry, and some were bordered for a long extent by trees; others showed only patches of bush, and were destitute of the ornament of shady trees. 
With no more variety of scenery than this, our journey continued for many days, and the monotony was only seldom broken by the appearance of an isolated conical hill, or table-shaped rock, which, on account of its rarity, we regarded with great interest and attentively examined.

The prairie dog, as it is called, though in fact it is no dog at all, but a marmot*, is certainly one of the most curious of the living creatures found in these regions. It was named dog, petit chien, by the old Canadian trappers, on account of its peculiar cry, somewhat resembling the bark of a small dog, and the name has continued in use to the present day. The almost incredible extent of the settlements, or villages as they are called, of these peaceful little inhabitants of the earth, can be appreciated when you find that for days and days together you are travelling among small hills, every one of which marks an establishment of this kind. The single dwellings are generally eighteen or twenty feet apart, and the hillock at the entrance of each consists of a good waggon-load of earth, which has been gradually thrown up into the light of day by the little inhabitants in constructing their subterranean abodes. Some habitations have one, others two entrances, and the firmly trodden path leading from one to the other gives rise to the conjecture that relations of friendship must subsist among these lively little animals. Their choice of a site for their villages appears to be determined by the presence of a peculiar kind of short crisp grass, which flourishes on these elevated plains, and which forms their sole nourishment; and their 
populous republics are to be found even on the lofty table lands of Mexico, in places where for many miles round there is not a drop of water, and where no rain falls for many months. Water can only be obtained there by digging to a depth of a hundred feet, so that it is to be presumed that the prairie dog does not need it, but is satisfied with the moisture afforded by an occasional heavy dew. The winter they doubtless pass in sleep, for they lay up no store for that season, and as the grass is withered in the autumn, and the ground afterwards hard bound in frost, they cannot obtain their food in the customary manner. When they feel that their sleepy time is approaching, which is commonly towards the last days of October, they close all the entrances to their abode to protect themselves against the winter's cold, and then settle themselves to their long sleep, and do not wake again till the warm spring days recal them to joyous life. The Indians say that the prairie dog does sometimes open the doors of its house during the cold weather, but that this is a sure sign of warmer days approaching.

A small species of burrowing owl* is often found as a joint tenant of these subterranean dwellings, and appears to live on good terms with the small quadrupeds whoinhabit them; but the owl is more common in the villages that have been abandoned by their original occupants. The prairie rattle-snake also sometimes introduces himself; but it is a great mistake to imagine, as has sometimes been done, that he comes as a friendly visitor; and when the unpleasant sound indicating the presence of

* Athene hypogrea, Bonaparte. 
the poisonous reptile is heard from one of the villages, you may be sure that if it had not been previously forsaken by its tiny population, the rattle-snake has either driven them out or devoured them.

These little colonies present a curious appearance if you can succeed in getting near before their sentinels have given the alarm. As far as the eye can reach there is a busy life and bustle going on; a little yellow brown personage, something like a squirrel, is sitting upon every hillock, with his little tail sticking up, and in everlasting motion, while thousands of small voices unite in chorus. But let the spectator make a few steps further and all life has vanished as if by enchantmentvanished from the surface, at least; but here and there you may see the head of a little scout peeping out of a hole to reconnoitre, and by his defiant bark seeming to warn his fellows of the dangerous vicinity of man. If you then lie down, and remain motionless, you will find that in a short time the sentinel will leave his post at the door to place himself upon the hill, continuing his barking-we may now presume to announce the more secure condition of public affairs. One citizen after another is then enticed out of the dark passages to the light, and the harmless bustle of the social creatures begins again. Sometimes you may see a steady-looking old fellow going to pay a visit to a neighbour, who receives him sitting upright upon his hillock, and wagging his tail; and then the two sit down together, and in the barking duet that follows doubtless communicate their reciprocal thoughts and feelings. Sometimes, after a little earnest conversation of this kind, they will retire into their dwelling, and then set out together on a walk, it may be to visit some relations; these meet with other pro- 
menaders, and loud salutations follow, and after awhile the party breaks up and every body goes home. One may amuse one's self for hours with watching the curious ways of the creatures, and it is impossible to help desiring such an acquaintance with their language as might enable one to find out their retreats.

The prairie dogs venture fearlessly between the hoofs of the wandering buffalo; but the lightest movement of the hunter, who is watching them, is sufficient to send them all flying down into their subterranean retreats, though a sound of barking from below the ground, as well as the number of the forsaken hillocks, betrays the presence of the bustling little community.

The flesh of these animals is agreeable to the taste, but the chase of them is so difficult, and so seldom successful, that they are not often pursued from any other motive than curiosity. The creature, indeed, is scarcely as large as a squirrel, so that a considerable number of specimens would be required to entertain even a small party, and you will see many that you have wounded manage to roll down the almost perpendicular passages into the earth, before you succeed in bagging one.

All around us now is one wide green plain, but here and there, far away on the misty horizon, a blue tableland is visible; a glowing hot wind is stirring grass and flowers, and from time to time whirling up a thin column of dust to the clouds. The panting mules toil along, the riders droop in their saddles, the atmosphere is oppressive; but far more so the monotony and dulness that have over-clouded the spirits of the party. In this extremity recourse is had to the German naturalist and his story. Dr. Bigelow and several other members of the expedition have gathered round him, 
and at their request he continues the recital of his adventures in as lively a tone as circumstances will permit. "The way to the camp of the Indians," he began, "was not more than two miles, but to me it appeared very long; the little group that had preceded me had broken a sort of path through the deep snow, but as I followed it I felt how completely my strength had deserted me. I was so entirely exhausted that I could not think without dismay of the long marches that awaited me in the next few days. My new companions, however, had noticed my extreme weakness, and kindly altered their whole travelling plan out of consideration for my welfare.

"Their little camp consisted of two large tents, which stood in a deep ravine, overgrown with stunted oaks, and on the banks of a deep stream, whose waters were hidden beneath a thick covering of ice. Every thing was covered with snow; but the storm could not find its way down into this sheltered hollow, to shake the tent poles, or disturb the little shaggy horses in the business they were engaged on, namely, that of scraping away the snow with their hoofs, to get at the scanty supply of food beneath.

"A feeling of real comfort came over me as I scrambled down the steep bank into the ravine, and came in sight of the asylum destined for me. My companions had already arrived, and also my little waggon, and the brown wild-looking band was busily engaged in stowing away the various packages and bundles in the spacious tents.

" 'Au-tarro-hau' sounded towards me from all. quarters, and the cry of welcome was further corroborated by the men all shaking hands with me, whilst 
the women and children gazed at me curiously, and doubtless had a certain feeling of satisfaction in finding a white among them who was certainly in worse case than themselves. The children, indeed, were evidently afraid of me, but this was not surprising, for my beard and my hair formed one wild entangled mass, and my skin was stained, partly by weather, but much more by the constant smoke I had been exposed to, of a dark brown. My clothes were scanty and much torn, and I had thought it expedient to fasten my shoes on my feet with leather thongs.

"In this certainly picturesque costume I now stood before the tent of the hospitable Ottoes. ' Wigwam-Petsche-Pi-ke,' said the medicine man, now addressing me, and pointing to an opening in his tent. 'In the wigwam there is a good fire,' said Louis Farfar, translating for my benefit; ' $g o$ in and warm yourself, and eat and drink with $W a-k i$-ta-mo-nee, and then come into my tent: there you can live, there you can sleep; my dwelling is large enough and warm.' I willingly obeyed his suggestion, crawled into the tent of the medicine-man, and took my place by his blazing fire, while the other occupants lay or crouched around. The old mother was busy in the preparation of the meat, and by her side, next the opening, were two daughters; the elder about eighteen, the younger about two years old. The father of the family, his son, and Schin-ges-in-ki-nee had, according to Indian custom, kept the best places for themselves, which was so much the better for me as I was placed between them. The medicine pipe, with a bowl cut out of some red stone, went round briskly, and the time that was employed in distributing the meat intended for the meal I spent in taking a good view of 
the Indian dwelling. Sixteen long poles, made of slender pine trees, were so placed as to form a circle of sixteen or eighteen feet in diameter, their tops being bent over and fastened together. Around this framework was thrown, like a mantle, the tent leather, consisting of a great number of buffalo-hides, tanned white, and neatly sewed together for the purpose with sinews. The leather did not reach quite to the top, but left an opening, by which the smoke could escape; but there were two prolongations of the tent leather, something like flags, which were supported by particular poles, so as, in stormy weather or contrary winds, to form a very tolerable chimney. The tent was fixed so firmly to the ground with pegs that the tightly stretched sides would admit neither the rain nor the snow, when it melted from the heat of the fire; and the inhabitants had not only a secure refuge, but a tolerably comfortable dwelling. The various possessions of the Indians were hung round on the tent poles, where they only took up room that could easily be dispensed with, and kept out the cold that could have most readily found an entrance at those places. On the space round the fire, buffalo-hides were spread for beds at night, and when rolled up in the day made convenient seats; the fire, in a kind of pit half a foot deep, and two and a half in diameter, was a mass of glowing embers, with a number of logs blazing on the top, and diffused a most pleasant warmth over the small space. Near the fire a branch of a tree was stuck into the ground, and another placed horizontally across it, and running the whole breadth of the tent, from which hung the most indispensable of household utensils in the form of a great kettle, whilst the rest of the pole was covered with wet and torn mocassins and 
gaiters, in a manner that was certainly more convenient than ornamental.

"This description of an Otto tent you may take, my dear Doctor, for that of all the Prairie Indians when they are on their travels. The differences that are found in those of different tribes - such for instance as those of the Kioways, who dig their fireplaces only two feet broad, and of the Comanches, their nearest neighbours, who make them half a foot less - would not be worth noting, but that it is sometimes necessary for your own safety to be able, when you have come to a forsaken camp, to determine whether you are on the track of friendly or hostile Indians.

"Besides the wild half-naked forms of the Indians, a number of dogs, young and old, made part of the company assembled in Wa-ki-ta-mo-nee's tent. The attention of the mistress of the family, a very dirty old squaw, was exclusively devoted to the vast kettle and its bubbling contents; a row of roughly-cut wooden platters stood before her, and by means of a pointed stick she fished up from the cauldron large joints of bear and half turkeys, and loaded each of the platters with a huge portion of the savoury smelling food. In this occupation she got into occasional disputes with the thievish dogs, and found herself under the necessity of letting her great wooden spit fall pretty heavily on the hard heads of the hungry marauders, before she could induce them to take their sharp teeth out of a piece that they had laid hold of. Then the unlucky dogs crawled yelping and growling away, and the lady continued the serving out of the meat. The supply of fat bits furnished to me was so superabundant, that, hungry as I was, I should certainly have required two days to make away with such a mass of food. 
"I did indeed find it excellent, and the medicine-man afforded me every hospitable encouragement, but with the best will in the world I really could not succeed.

"I pushed the remainder back, and thereby unintentionally lost much in the opinion of my hosts, who took this proceeding, so contrary to Indian custom, as a kind of affront. They allowed me, however, undisturbed and almost unnoticed, to retire into the tent of the half-breed Louis Farfar.

"This tent was more spacious than that of the medicine-man, and had fewer occupants, for besides Farfar himself and his handsome young squaw, Sche-ne-lo-tom, old Wo-nes-hee, his wife, and Scha-ho-ka-ta-ho were my only fellow-lodgers. I was appointed to share the couch of the last-mentioned personage, and accordingly betook myself with my weapons to his corner, to settle myself as comfortably as I could. Old Wo-nes-hee sent the pipe round, and I had once more the enjoyment of being able to hold conversation with some fellow creatures. I could not indeed avoid perceiving, from the ideas and words of Farfar, that I had fallen in with a decided rogue, from whom it was very necessary to be on my guard, but still it was delightful to hear once more intelligible words, and be able to express my own thoughts.

"I soon perceived, with terror, that preparations were making for another meal here, and I turned to Farfar saying, "Tell your women that I have eaten so much already, that I cannot possibly take part of this little refreshment, as you are pleased to call this pile of meat.'

" "You are enjoying the hospitality of the Ottoes,' he answered, 'and you would do well to adopt their customs and manners, at least as long as you remain 
with them. You see I lived long among the whites, and laughed at the follies of the Indians, but all on a sudden it occurred to me that I would be an Indian myself; so I bought a squaw, and can now take my part in the wars and the medicine dance like a full-blood Red skin. They trust me, and I have great influence among them. When you come into the tent of the Indians, the first thing they offer you is the pipe, and the second is victuals, and the more friendly they are, the bigger portion they will give you. The medicine-man loves you because you are a stout hunter and warrior, and so he gave you a respectful portion. You will presently get just such another from Wo-nes-hee, and it is your duty to acknowledge the kindness by eating up the whole mess. You have offended Wa-ki-ta-mo-nee, for you left more than the half of what he gave you. You must do better in future, and show that you know our customs.'

"' Had not you better ask me to eat dish and all ?' said I peevishly.

"' 'No' he replied quietly; 'we do not wish that, for it costs a great deal of trouble to cut out such a vessel.' - 'But you seem to have a mind now that I have escaped starvation to make me eat myself to death,' said I.

" 'No. I will tell you,' said Farfar, 'what to do when you are again invited to eat in the medicine-man's tent; when you have eaten as much as you can, wrap up the rest in a buffalo-skin, and bring it here, then we will help you.'

" 'Your customs differ a little from ours,' said I, feeling somewhat relieved. 'But shall I then take what I cannot eat of this mass of meat into Wa-ki-ta-monee's tent?' 
"No," answered the Half-breed, "put it behind your bed, and then when you wake in the night you need only stretch out your hand and get it; "the nights are long.' By conversations of this kind, Farfar endeavoured to initiate me into Indian customs, whilst I did my best to communicate some ideas of civilisation to the Indians. I found, however, that I came to resemble my companions more and more, at least in externals; and that it is easier for a white man to become an Indian, than for an Indian to adopt the manners and customs of the whites.

"The fire blazed brightly on the first evening I passed in my new home in Farfar's tent; dried buffalo meat and beaver's tails were boiling in the mighty cauldron; with the exception of an old squaw, who attended to the cooking, every feminine person had disappeared from our company, and a circle of old and young warriors sat round, solemnly passing the pipe from hand to hand. We were about to hold a council, the Medicine man was president, and the Half-breed acted as interpreter. Wa-ki-ta-mo-nee took a long puff from a medicine pipe, handsomely adorned with green ducks' heads and the white beaks of black woodpeckers, let the smoke pass through his nostrils, contemplated the blue cloud floating upward, and then he made a long speech all about me, of which I did not understand one word. I listened, however, to the sonorous voice, and the words that seemed to melt into one another like the notes of music, and then the Half-breed translated the speech for my benefit. It was about as follows :-

"6 The way to our wigwams is long, and if the feet rest, deep snow covers them; the way is long from wood to wood, it lasts from sunrise to sunset. The horses 
are laden with meat and skins; the backs of our women with their children; we must all go, the American shall go with us. The flesh of wolves was long his food, he is hungry and without strength; he cannot reach the wood in the evening, he is tired; he should long since have closed his eyes, but the white wolf threatened him. The American must sleep and eat three days and three nights; he must eat dried meat and fresh meat, and then he will walk so that the squaws and the children may not laugh at him.

" "Our women shall sew mocassins on his feet, and fasten raw buffalo hide under them, that the stubble of the burnt grass may not stick into his white flesh. The American has a short gun, but he has long bullets; the Ponka, whom we meet, will shoot the white brother; the white brother must be an Ottoe. Let us shave off his yellow hair, and dye the scalp with black, and rub vermilion into his face, then he will be an Ottoe, and can take an Ottoe squaw for a wife.'

"This was, as nearly as possible, the substance of the speech; it was evident that the people meant honestly by me; and the first part of the oration I entirely approved of, but the two last clauses I thought required consideration. I had not the least wish to part with my yellow locks, though I must own they were not at that time in appearance unlike a bunch of tow; and as for running about in January with my head shaved, I thought I should rather prefer being a mark for the arrows and bullets of the Ponkas and Siouxes. I considered also, that if we did happen to fall in with these tribes, my shaven pate would scarcely secure me from getting scalped, since I was in company with their enemies, the Ottoes; but far worse than the shaving, 
and all the rest, was the plan of the marriage. The hair would sooner or later grow again; but how should I get rid of the Indian wife?

"In this awkward predicament I thought I would temporise a little; and I was pondering on some method of declining the proposal, and still retaining their good will, when Louis Farfar came to my assistance, and addressed his companions in my name to this effect:

" "The American is a brother of the Ottoes, he loves them, for they have saved him; he will smoke with them, eat, hunt, and make war with them on their enemies. He has longed slept in the snow, and had many a good dream; and in the dreams he has seen Ottoe hunters who have shaved his head, but from every hair came snow flakes, and the storm wind came behind the snow flakes and drove them to the wigwams of the Ottoes, and buried every thing in the snow. The American is poor now; he must sleep in the wigwams of the Ottoes, and eat out of their hands. He would like to take two daughters of Wa-ki-ta-mo-nee into his tent; but he wishes to pay with open hand for his squaws; and sleep in his own wigwam. He will first shoot thirty buffaloes, and have their hides tanned by the squaws of the Ottoes, and sewed into a tent leather; and he will steal six horses, two for himself, two for his wives, and two to pay the great Medicine man for his daughters.'

"'The Ottoe listened with attention, and evident satisfaction to this extempore explanation of Farfar's; and was so much pleased with the noble character therein ascribed to me, that he offered to hand over his daughters to me upon the spot, and allow me to pay their price in horses afterwards. He agreed also that I should not cut off my hair and beard, since the good dream had prophe- 
sied misfortune in such a case. Farfar, however, rescued me from the proposed ' mariage de raison,' by declaring positively that it was 'against my medicine' to enter the estate of matrimony without having honourably paid for my wives beforehand. I was allowed, therefore, to remain a bachelor, and had even risen in the estimation of my friends, for I received, almost daily, such a heap of meat from Wa-ki-ta-mo-nee as an Indian would only present to a future son-in-law. The debate was concluded by another feast, and then every one retired to bed.

"It was with a peculiar feeling of comfort that I stretched myself at last under my coverings; the glowing fire warming me on one side, and the person of Scha-ho-ka-ta-ho, who shared his couch with me, on the other. I should have had nothing left to wish for if the dogs had not thought proper to lie upon me, though my lean limbs must have afforded but an indifferent couch.

"Whether I had taken their accustomed place, or whether they meant to show their contempt for me as a stranger, I do not know; but I lived in a constant state of feud with these animals, and had only occasionally the revengeful consolation of eating one of them, when, on special occasions, one was killed and cooked.

"Amidst, eating, drinking, sleeping, and breaking in two horses to draw my little waggon, three days passed away; and such a change had been effected in my outward appearance, that I was now scarcely to be distinguished from a Red-skin. I was fitted out with garments of their fashion, my face was painted to superfluity, and in the finest style of art, with red and yellow oil-colour, and the Indians now evidently regarded me as a good-looking and promising young man, who need 
not despair of becoming an Ottoe warrior. The children were no longer afraid of me, and the bright eyes of the ladies, I flattered myself, rested with particular satisfaction on my visage - glorious in all the colours of the rainbow. I did not object to accommodate myself in this manner to their ideas of the beautiful, especially as I had remarked that this layer of oily colour formed an excellent defence against the cutting cold, and prevented the skin from cracking in the icy wind. My strength had in the meantime greatly increased, but still I was not at the end of three days considered by the wise Medicine man fit to undertake a journey, and it was therefore agreed by the Indians to defer their departure for two days longer, after which it would be absolutely necessary to start."

"I must interrupt your story," here broke in the Doctor, "I have studied botany long enough to know that those dark streaks down there in the hollow mean grapes, and those grapes must now be ripe, so I invite you all herewith to a banquet." We all accepted the invitation, with the reservation that the grapes should not turn out sour, and a short ride in that direction convinced us that the Doctor's sharp eyes had not deceived him. A considerable space was covered with low vines, and those so loaded with grapes, that the already autumn-tinted leaves almost disappeared beneath their clusters; so after we had sought out a suitable place for the animals to graze in, we threw ourselves down among the twining branches, and revelled in the blue juicy fruit to our heart's content.

A sudden cry of "The Comanches!" however, roused us pretty quickly from our Epicurean indulgences; we were immediately in our saddles again, and N 3 
hastening up to our advanced guard, who it seemed had met with two scouts or spies of this tribe, but their companions were seen prancing about their horses at a distance without showing any special desire to meet with the whites, and they soon in a mysterious manner vanished in the direction of the Canadian.

The visitors were two gloomy-looking, elderly warriors; mounted on magnificent horses, which obeyed in the most graceful manner the slightest touch of the rein fastened to their lower jaw, and seemed to form one body with their riders, who rode without saddles. A blue blanket formed the only clothing of these savages, and they held their bows and arrows in readiness for immediate use, while the wildness of their appearance was much increased by the very long hair that fell round and partly covered their bronze faces. According to their declaration, we were not likely to be troubled with many of their tribe, since only a small division of them had a camp about a day's journey off on the Canadian ; a larger party was at this moment engaged in a predatory expedition to the southern settlements of the whites, and the greater number had followed the buffalo to the northern regions, and would only return with them late in the autumn.

The warlike and far spreading nation of the Comanches, is divided into three great tribes, the northern, southern, and middle; which are again subdivided into various bands, led by distinguished warriors, medicine men, or by pettier chiefs, with whom they traverse the prairie in all directions. The northern and middle Comanches constantly follow the wandering buffalo, whose juicy meat forms almost their sole support, and who are thence appropriately named by 
their "neighbours the "Buffalo-Eaters." The wide steppe is their home, and their unconquerable love of wandering carries them from place to place over these desolate inhospitable regions, where the pure invigorating atmosphere alone compensates for the scarcity of wood and water. Their territory is free from morasses, stagnant pools, or thick woods, where any unhealthy and fever-breeding miasma might be generated; the currents of air find no obstacle on the boundless plain, and as they blow freely across it they seem to strengthen both the body and mind of the dwellers on the steppe. Kind mother Nature often affords men some compensation for the adverse conditions of life to which they are exposed, and she has here bestowed on them some of her best gifts, - health, cheerful spirits, and all-enduring strength. The flexible nature of man soon accommodates itself to the hardest conditions of climate and soil, and the tribes who inhabit this wilderness, are quite convinced that their country is to be preferred to the whole world. There are indeed white settlers enough to be met with in the far west, who are a good deal of their opinion; who shrink from the advances of civilisation and the increasing population that accompanies it, preferring the wilderness with its dangers to the personal security, convenience, and pleasures of social life; it may therefore well be imagined that the wild children of the steppe are attached to their grassy plains.

The Comanche Indian knows of no wealth but the buffalo and the antelope, and the horse that enables him to overtake them; with these he has food, clothing, and shelter, and he desires no more; he is not troubled by cares for the coming day; and in his wars with his 
enemies and his management of his horse he finds the means of gratifying his own ideas of honour. From his earliest childhood to the latest day of his life he is continually on horseback, indeed he makes but an awkward figure enough on foot, though he is no sooner mounted than he seems transformed; and when with no other aid than that of the rein and a heavy whip he makes his horse perform the most incredible feats, he considers himself the greatest and most independent gentleman on the face of the earth. You may often see troops of Comanches dashing about in all directions, and playing the wildest tricks, hanging now on one side of the horse, now on the other, and throwing lances or shooting arrows under his neck with the most astonishing accuracy at a given mark; though one cannot help thinking, while admiring their feats, that this wonderful skill in horsemanship must make them so much the more dangerous when they come on their plundering or hostile expeditions.

Every Comanche Indian keeps a special war-horse, in the choice of which more regard is had to swiftness than to any other quality. As among the Arab tribes, the horse is the best friend, the most sacred possession of his master, who would not part with it for any treasure that could be offered him, and mounts it only for war, or peculiarly festive occasions, such as a buffalo hunt; and when he returns he finds his women awaiting him at the door of his wigwam, to receive the beloved steed, and pay him every attention.

With the exception of a few cooking and domestic utensils, the sole possessions of these Indians consist of horses and mules, many of which have evidently, from the brands upon them, been stolen from the settlements 
of the whites; but the appropriation of other people's goods is considered creditable, and a young man is not thought worthy to be counted in the list of warriors, till he has returned from some successful plundering expedition into the Mexican provinces, so that the greatest thieves are not only the most opulent, but the most respectable members of society. A grey old warrior, who was heard praising his two sons, and declaring them the joy and support of his age, did not fail to add that they understood horse-stealing better than any young fellows in the whole nation. It is not therefore surprising, that some particularly meritorious persons have accumulated a herd of from two to three hundred of these testimonies to their prowess.

Parties of from one to thirty young men are in the habit of associating for the execution of these predatory enterprises, which, on account of the dangers and privations connected with them, are placed in the same rank with those of a directly warlike character. Every one provides himself with a horse, weapons, and what is necessary for a journey of hundreds of miles through the desert, where the game is but sufficient to afford them a very scanty support. They will travel this way sometimes for months before they approach a settlement, and lie in ambush waiting for an opportunity of falling with wild cries and yells on the keepers of some solitary herd, and either drive them away, or, in case of resistance, kill them, drag away their women and children as prisoners, and ride off with their booty to their wigwams. In some cases they are absent as much as two years from their camp before finding an opportunity of executing their plundering plans with success, and every man dreads the disgrace of returning 
with empty hands to his people. Sometimes, of course, the Comanches fail in these attempts, and are beaten. Alexander von Humboldt mentions having seen at the beginning of the present century in the prisons of the city of Mexico, whole bands of these Indians, who had been sent southwards from Taos and Santa Fé, in New Mexico.

Another way by which the prairie Indians increase their herds, is by catching the mustangs, or wild horses of the American steppes ; small but powerfully built animals, and unquestionably the descendants of those brought into the country by the Spaniards at the time of the conquest of Mexico, which, having escaped into the desert, and become wild, have since increased to herds of thousands, and animate the prairies from the borders of Texas and Mexico to the Yellow Stone, a confluent of the Northern Missouri.

The Indians soon learned to estimate the useful properties of the new animal in bearing burdens, and they also had recourse to them for food in seasons when the buffalo was difficult to obtain ; at present the catching the wild mustang is an occupation or a sport, to which they give themselves up with all the wild passion of which these untamed children of nature are capable.

With a lasso forty feet long, they follow the flying herd, and having, by the most unmerciful use of the whip, brought up the horse they are mounted on near enough to use it, they send it whirling and flying out of their hands, and with unerring aim right over the head of the victim selected. After a short struggle, the mustang falls half-suffocated; a leathern throng is quickly passed round his fore legs, and then the lasso round his throat so far relaxed as to avoid quite 
choking him. The Indian then fastens a rein to the lower jaw of his prisoner, breathes several times into his open nostrils, takes the fetters from his neck and feet, and jumps upon his back. Then follows a ride for life and death, but at last the creature is mostly brought in tamed, and placed among the herd; and wildly and cruelly as the Indian appears to go to work on such occasions, he is extremely cautious not to break the spirit of the mustang in taming him, for in that case the flesh would be all he would get by his dangerous and exhausting labour.

The two Comanches accompanied our expedition but a short way, and then went off in a northerly direction ; possibly after having satisfied themselves that as our party was a well organised and armed force, it would not be possible to levy tribute from us. After their departure, there was little else to interest the individual members of the expedition. The many dry beds of rivers or brooks, with their reddish sands, contributed much to the mournful and desolate character of the scenery, and from time to time horizontal masses of rock, the remains of a portion of the Llano Estacado, stood out like the ribs of a mighty skeleton. The Antelope Hills, between which the way had led us on the 7th of September, disappeared in the blue distance on the 8 th, and on this day we reckoned 424 miles since leaving Fort Smith. Then we were all longing for the vast sublime prairie, with all its wonders, and now there were few who would not have preferred the shady forest, with its rich decoration of autumnal leaves, to the hard ground and short grass over which we were slowly toiling under the oppressive September sun.

During the whole day we had never lost sight of 
a small wooded ravine near the Canadian river, and we all desired to reach this point if possible by sunset, and pitch our camp there, for every one expected to find in that ravine some advantages corresponding with his peculiar inclinations. "Where cotton-wood trees grow there must be water," said those who had the welfare of the cattle most at heart. The waters of the Canadian were here scarcely sufficient to cover the sand they rolled down, and even a shallow pool at the mouth of some tributary stream would have been a real blessing for the whole expedition. "Wherever in the steppe there are trees, you are sure to find game," said the enthusiastic sportsmen, and they gave their horses the spur. "Where there is wood, we shall not have to put up with grass stubble and buffalo dung for fuel," said the cooks, and hurried on, wisely calculating that the company would hurry after them, and they were not mistaken in their calculations. Before sunset the dusty waggons were drawn up in a circle, the airy tents ranged side by side, the camp-fires were blazing, and all around them was bustle and animation. Some of the company went out to seek for water, and possibly to make prize of a turkey or two, but soon returned with unwelcome intelligence. The bed of a stream certainly wound beneath the high trees, but as far as the moist sand of the Canadian, there was not a drop of water in it, much less a good place for watering the cattle, so that at last they had to be driven down to the shallow bed of the Canadian, and since no better was to be had, its sandy water had to serve for cooking, and then the company dispersed to engage in various occupations. A cry of "Supper ready, gentlemen," from the sooty 
cook, soon brought them all with their camp stools to the several tables; but one seat remained empty. "Where's the German?" cried one of the young men. "I met him on the other side of the wood," was the answer; "he was following the track of a panther ; but as it seemed to be leading him further and further from the camp, I left him and the panther to settle it." Just then a shot was heard. "There he is, most likely," said some one, and there was no further anxiety about him.

The meal was nearly finished, when from the dark shadow of the wood issued a strange-looking figure, which was seen to advance hastily towards the camp, and was recognised immediately as the lost one - but in what a pickle! At every step the water trickled out of his boots, and his wet clothes clung to his body; but on one shoulder he carried his rifle, and on the other a mighty turkey.

"What in the world has happened to you?" was heard from all sides. "Why you've got more water in your clothes than can be found in the Canadian in a day's journey."

"What should have happened?" replied the hunter; "here have we been for days together looking in vain for water, - and now in the night, just as we have managed to do without it, I go plump into such a deep pool that $I$ find it no easy matter to get out again. Just let me get off these heavy clothes, and get something to eat, and then while I dry my rifle I will tell you my adventure. It had very nearly cost me my fine rifle, and perhaps my life into the bargain."

After these preliminaries, the adventure was thus related. "As I was wandering about in the wood, looking 
for water, I discovered on the sand in the dry bed of a stream, fresh traces of a fine-grown panther, which I supposed to be still lurking about the wood, and I cautiously followed where they seemed to lead. The fellow must have been in the wood when we arrived, for his track crossed it in all directions, as if he had not been able to make up his mind what to do under the circumstances. I followed his broad footsteps patiently, till they led me out on the other side of the wood (where I met Mr. Campbell), and then straight to the Canadian, where the crafty animal had turned to the eastward, creeping along the high bank, under shelter of the scattered trees and bushes. I hoped to be able to rout him out, and so went on and on, till at last the setting sun warned me that it was time to turn back; and though I was vexed enough to give up the chase, I shouldered my rifle, and turned round, when at that moment, not ten steps from me, there was a rustling in the bushes, and I beheld - no! not the panther, as you are all thinking, but a fine fat turkey, which just fluttered heavily to the next tree, where my bullet soon reached him. The shot awakened not only the echo on the high bank, but also a whole flock of these birds, from some hiding-place among the boughs, and they went flying in all directions. I hit a second with my left barrel, and then slinging the two over my shoulder, as soon as I had reloaded, I trotted back, tolerably content, the same way by which I had come, as nearly as I could tell. But by the time I had reached the mouth of the ravine, it was quite dark, and I could hardly make my way through the thick bushes. Presently I was startled by a sound among the leaves, but 
it was only a sleepy turkey, probably one of the flock I had frightened away, which just moved a little further, and placed himself on a withered branch immediately before me, as if he had really been inviting me to shoot him. I had fastened one of the two I had killed to my belt, and was carrying the other in my hand, but this I now laid down gently, to have a try for a third. I was a long while taking aim in the dark, but at last I fired, and the bird fell, flapping his wings, but I did not think by the sound that I had killed him ; so, in order to catch him before he recovered himself, I gave a great jump, and down I went over head and ears into some deep water. How deep I sank, I cannot exactly say; but I could feel no ground under my feet. I was in an awkward case, for I would not let go my rifle, and I had the heavy bird fast to my belt and my shoulder. I do not think, however, that it made me sink on the contrary, I believe it helped me to swim. Fortunately I had instinctively caught a branch with my left hand as I fell, and this enabled me, by a desperate effort, to place myself, as well as my rifle and my turkey, once more upon dry land. Had I lost my rifle, I should have been inconsolable; but as it was I had to mourn the loss of two turkeys, for I could not tell in the darkness where to look for them, and I should not have liked to try for fear of tumbling into another hole; so I worked my way through to where I could see the light of your fire, and here I am with one turkey instead of three, but with the satisfaction of having discovered in the dark the water that you could not see in the daylight." "It is well you saved that one," said one of the party; "he will make us a capital roast to-morrow." "Yes," 
answered the sportsman, "but I would gladly give him to be able to make out how such a hole as that, a hole of small circumference, and seemingly shaped like a funnel, could remain full of water, in a place where the wet quicksand seems to fill immediately any hole you can dig." 


\section{CHAP. XI.}

THE DRY RIVER AND ITS PECULIARITIES.-THE GREAT COTTONWOOD TREE. - MODE OF TRAVELLING IN THE STEPPE. - THE NATURALIST'S ACCOUNT OF HIS STAY AMONG THE OTTOE INDIANS. - ARRIVAL OF THE EXPEDITION AMONG THE KIOWAY INDIANS. - CONVERsation With them. - PASsage of the CANAdian. DOCTOR BIGLLOW'S ESCAPE FROM THE QUICKSAND.

THE march of the following day brought us at an early hour to the Dry River, a river which from its remarkable properties deserves particular mention.

The Dry River rises in the Llano Estacado, near the sources of the Sweet Water Creek, or rather of the Northfork of the Red River of Texas, and carries its waters in a north-westerly direction to the Canadian. The bed of the Dry River is proportionably broad, for near its mouth it measures above 600 feet, a remarkable breadth considering the shortness of its course. The valley, with its high, broken, jagged banks, extends in the same proportion as the river bed on both sides, and ten miles above its mouth is several miles broad. The geological character of this valley makes it very obvious why the conical hills, and table-shaped rocks, lying scattered about the prairie, are to be regarded as the remains of a part of the Llano Estacado. The Dry River, with its broad valley, probably owes its origin merely to a buffalo path, which wild, rushing torrents transformed into a brook. Deep ruts and clefts, formed in the same manner, opened into it, bringing fresh. 
streams of water, the united force of which was soon able not only to carry away the sandy soil, but to break through the horizontal stratum of white sandstone lying imbedded in it. The brook then became a ravine, in which the newly-formed river wore itself a broad, convenient bed, widened its valley to its present extent, and will widen it more, since the same causes are still in operation. The heights that inclosed the valley were in this way gradually undermined, and separated from the plateau, and since the covering stratum of sandstone, yielded less readily to the destructive influence of time and the elements : hills were gradually formed, which, cut off from the surrounding plain, and covered by the everywhere superincumbent rock, resemble the Antelope Hills and the Natural Mounds, though not equal to them in extent. Their formation belongs to a recent epoch, while the other rocks seem to date from an earlier period. One characteristic of most of the flowing streams of this region is peculiarly striking in the Dry River. When the water is low, the river is dry at its mouth, but has water in places further up; in some of these the water collects only during the night, and as the sun rises and gathers strength, it dries up again. The cause of the first may be that the heap of sand accumulated at its mouth, is too great for the river to do more than trickle through, as it happens so frequently and so strikingly to the tributaries of the great Colorado of the west in the region between $34^{\circ}$ and $37^{\circ}$ north latitude. Rapidly flowing streams are there suddenly lost in the sands, trickle beneath the surface for many miles, and then as suddenly make their appearance again, gushing out quite unexpectedly from the seemingly dry ground. 
The second circumstance may be accounted for when we consider that the evaporation from the heated sand is too great, when the sun is up, for the water to keep the upper hand, but as soon as the atmosphere has become cooler it gains the victory.

Our expedition crossed the sandy bed of the Dry River about a mile from its mouth in the Canadian; it was still early in the day, and here and there sparkled little pools of water, with whose existence and periodical recurrence the wild animals must be well acquainted, for the tracks around them, as well as the presence of deer and antelopes in the neighbourhood, left no doubt that they come down in the morning hours, when the water is at its highest, and take the refreshment that has to last them for the whole day. There was, indeed, water enough in some of the hollows to the west of the river, but it was bitter and undrinkable, and in some places there was a deposit of magnesia, looking like hoar-frost on the blades of grass and leaves.

About noon, our road led us past a tree that rose solitary on the plain, and was remarkable both for its gigantic growth, and for its strangely twisted and entangled boughs and branches. It was a cotton-wood tree, centuries old, and had a diameter of twelve feet; at the height of about six feet from the ground, it divided itself into two mighty arms, which stretched themselves far out, and with their numerous boughs shaded the arid ground. Young shoots, hanging down, had become trees, and supporting themselves with their whole weight on the ground, raised again their leafy crowns to mingle with the foliage of their venerable parent, and increase the grandeur of his appearance. 
The sight of such a tree in the dreary sunburnt steppe, is as pleasant as the sight of an old friend, and you do not grudge making a considerable circuit to rest for awhile in its welcome shade, and give yourself up to the dreaming fancies called forth by the figures cut long ago, in its bark, by Indians, or, perhaps, by whites, in sport. Grand as it looked, with its vast boughs, and myriads of glittering leaves quivering in the lightest breath of wind, - and though hundreds of years had doubtless passed over it,-its life has been but a span in comparison with the thousands of years required to transform the bottom of an ocean covered with salt waves, into this green prairie, after the Almighty will had elevated the ground, and driven back the waters, to open a fresh and boundless field for the active powers of vegetation.

Winds and birds carried seeds to the newly-formed plain, and it was soon covered with a mantle of rich verdure, and many-coloured flowers, - a mantle so thick, close, and impenetrable, that the tender germ of a young tree could but seldom force its way, and raise its head above the waving sea of grass. How many summers and winters, we thought, have passed away from the time when this tree was a tender germ, to that in which it spread out its vast arms for the birds to build their nests in, and the red men drew these figures of rattlesnakes and long-necked horses on its bark?

One of our companions recognised traces of travelling Indians. "Fresh tracks of Indians are fresh reasons for caution," said he, addressing the party lying at their ease under the shade of the giant tree; "our waggons and their escort are a long way on before, there 
are but few of us here, and it would seem by these marks that a considerable troop of Kioways or Comanches must be somewhere in the neighbourhood. Our mules have got enough for the present, and they will certainly be of our opinion." The loiterers, therefore, of whom I was one, saddled their patient beasts, climbed leisurely into their saddles, threw one parting glance upon the beautiful tree, and then turned into a freshly-broken Indian path, which led in the direction taken by our main body.

"It is very remarkable," said the doctor, who was riding between an engineer and his German friend, "we are here riding three abreast, and yet each of us has a special good path to himself. Our company, with their heavy waggons, leave only two lines with the wheels; whilst the Indians, who travel on horseback, and on foot, make three, as we see here, and they run as exactly parallel as the tracks of our waggon-wheels. How can this be?" "Perhaps if the Indians have not waggons, they may have wheelbarrows," suggested an American. "Wheelbarrows, with two wheels standing eight feet apart!" replied the doctor, laughing. "I'll make it clear to you," said his companion on the other side, the German friend, who was fond of bringing forward his experiences. "I have already described to you how the Indian tents are made with buffalo hides and poles; well, when the Indians are going to travel, they roll up these hides and poles, and all their other chattels into great bundles. The tent-poles are so distributed, that each beast of burden carries four or five, the thick, heavy ends being fastened into the bundîs, and the tops, which are lighter, dragging along on the ground on each side. These two side 
marks, therefore, are made by the tent-poles, the middle one by the horse, and the squaw thereunto appertaining, who leads him; and all the animals belonging to the wigwam are fastened, one to the tail of the other, and follow exactly in each other's footsteps. The buffalo leather stretched between two of these tent-poles is sometimes used to transport sick and infirm members of the tribe, and save them the fatigue of the march; and as the dogs in an Indian family are expected to take their share of the work, a smaller leather stretched in the same way, and to which they are fastened by broad leathern thongs, is used for the transport of light articles, and sometimes, also, of children. If you see signs of conveyances of this kind in an Indian trail, you may take it as a sure sign that they are not on a war party, as the women and children are with them. They never carry tents with them when they are out on a warlike or plundering expedition, partly, of course, not to be encumbered, but also that they may not be under the necessity of putting them up themselves, as they consider that women's work, and beneath the masculine dignity."

When they mean to undertake a journey in the severe season, and wish to have the weather as propitious as possible, the first thing to be done is to apply to their Manitoo, and smoke and sing at him till they see signs of a favourable change; which they receive as an indication that the Great Spirit has heard them, and approves their intention. I witnessed this solemnity when I was the guest of the Ottoes, at the time when they rescued me from my dreadful situation on Sandy Hill Creek, for after they had taken care of me for five days, they considered me strong enough to travel, that is to 
say, to wade from morning till night through deep snow.

The day was therefore fixed for our departure, and on the evening before, good weather was sung for in due form. In Farfar's tent the fire blazed up brightly, the warriors sat crouched around, and the women and children, Wo-nes-hee's wife excepted, had left the tent. The kettle was hanging over the fire, but it contained nothing but boiling water; and since I had supposed that as a matter of course the festivities of the evening were to be accompanied by a grand feast, I had been during the whole day carefully sparing my appetite, in order to keep up my credit among the warriors, and do justice to the viands. I was really waiting with some impatience to see the dried buffalo meat and beavers' tails put into the steaming pot, but there was no buffalo beef to be seen, and though the beavers' tails certainly lay ready, they were not put in.

Tied up near the fire, and blinking at it with sleepy eyes, was a great shaggy wolf-dog, the same who had made such advances towards intimacy with me by lying upon me during the night. I concluded therefore that the Indians had tied him up out of politeness, that I might not be troubled by him during these solemn ceremonies. I little foresaw the tragic fate that was prepared for the poor beast, or dreamed of his connection with our gastronomic arrangements.

As soon as Wa-ki-ta-moo-nee had skilfully touched up the drawing of yellow lines which adorned my physiognomy the ceremonies began. The Indian drum, a hollowed-out block of wood, with a piece of buffalo skin drawn tightly over it, was first beaten in slow measure by two of the young men, and this drowsy, 
monotonous music was soon accompanied by a wild ear and nerve piercing song, given with the full musical strength of the company.

Hau! Hau! Hau! - Ottoe - Wine-bag - Ottoe - Wine-bagKero-kero-li la, \&c.

It was almost more than mortal man could bear without flinching. Kero, Kero, Kero, bellowed the Medicine man in response; and whirling his tomahawk round his head, he sent it whistling down on the head of the poor sleeping dog, and split its skull open. The song then ceased, and in a few minutes the dog was skinned and cut up, and deposited piecemeal, along with the beavers' tails, in the boiling pot.

"My poor unfortunate though troublesome companion," thought I, "was it then to devour you that I have been so carefully getting up an appetite?"

It is almost needless to say that my appetite had now entirely disappeared, but yet the "Medicine" meal was inevitable. I felt that I was observed, and I was on my guard. The flesh of the dog is in itself by no means so unpleasant as that of the wolf; I had already tasted it, and could easily have overcome my repugnance if I had not been so well acquainted with the animal. With a great effort of self-control, however, I managed to perform my part tolerably at the banquet, and I can certify that well-cooked $\mathrm{dog}$ is equal to any mutton. On the conclusion of our, alas, very abundant meal, we all went out to observe the state of the weather. It was dreadfully cold, the snow crunched under our mocassins, the stars glittered brightly, and the howl of the hungry wolf was heard through the night. The Medicine man cast keen glances into all quarters of the 
heavens, but no cloud dimmed the radiant, frosty sky. "The song was good," he exclaimed, "the rising sun will bring us favourable weather for travelling." "Well, but suppose in spite of the singing and the dog's meat a storm should come," said I, addressing the half-breed, "what should we do then?" "That happens often enough," said he, "and then we sing and eat again until we do get a fine day, but if the sun shines when we set out, we do not turn back for any storms that may happen on the way."

On the following morning the women were all in motion at an early hour, and I listened, as I lay, to the trampling of horses, and heard that they were driven up to the place and saddled, somewhat to my surprise, as the men were all lying, quite comfortable, tucked up in their respective beds.

I was not yet sufficiently familiar with the customs of these people to find it a mere matter of course. I can assure you, however, doctor, that nothing is more easily acquired than the habit of looking on at your ease, and seeing other people work for you ; and I found that I could soon sit with my male companions in dignified leisure at the fire, while the tents were taken from over our heads, and the buffalo skins literally pulled from under us.

Two horses were now harnessed to my heavily-laden little waggon, and the remainder of the chattels having been packed on the others, old Wo-nes-hee placed himself at the head of the procession, and stepped out over the snowy plain. I remained for a short time afterwards, sitting by the fire with the rest of the warriors, who were smoking, and apparently debating how long it would take us to get to the new camp. At length we 
broke up, and set off by twos and threes by various paths, and following the course of small streams, the banks of which were but scantily wooded, but certainly contained plenty of game. I followed the half-breed, and Sha-ho-ha-ta-ko, and in a short time had no idea in what direction the remainder of the party was to be found. I must own it is to this day inexplicable to me how the Indians contrive to travel without ever losing their way over these endless snow-covered steppes, where nothing meets the eye that can serve as a landmark. Long as I have lived with and accompanied them in their wanderings, I have never known a single instance in which one of them has gone astray, or failed to make his appearance at the camp at the appointed time.

I found it rather difficult to keep up with my companions, who proceeded at a half-walking, half-trotting pace, following the windings of the stream, and very seldom broke into the hard frozen snow. I chose my path along the higher ground, from which the snow was mostly blown by the wind into the hollows, and where the walking was somewhat easier to me. I did not generally lose sight of the two Indians, and I could also make out the course they were taking by the narrow strip of wood, so I sometimes ventured to cut off an angle of the road; but the sharp icy crust, over which the Indians stepped lightly and easily, frequently broke under my feet, and soon cut through the soft mocassins, so that it was not without extreme pain I could drag myself along. You may guess, gentlemen, how much I suffered from the fact, that when my two comrades got up a racoon hunt, I threw myself on the ground and watched their proceedings, without having any in- 
clination to share in a sport which had always afforded me so much amusement. This animal is very frequently seen in those regions, and its delicate flesh and very agreeably-flavoured fat, induced us to pursue it with eagerness, and endeavour to smoke it out of the hollow trees, which are its favourite abode. Whenever we caught sight of one, it was not long before we had it in our power. The plan was to make an opening in the trunk with a small axe, and push into it a bundle of burning grass, twigs, and leaves, so as to make a thick, suffocating smoke inside the tree. The racoon, or any creature that may be hidden there, is sure to come soon to the opening to breathe, and ultimately to escape to the nearest bough, where it is saluted with a bullet or an arrow. I could, however, on this occasion, as I have said, take no part in these proceedings, as I had to spare myself every step that I could, in order to get on at all. If I had lingered behind and missed my companions, I should certainly, in this terrible cold, have perished the first night, for I could not, without assistance, have made fire enough to protect myself from it. The Indians would probably not have waited, or gone back to seek me, for Farfar would have had no objection to become my heir, and the rest had such firm trust in the power of their Medicine song, that they would have considered it impossible any harm could have happened to me, unless, indeed, their Maintoo had appointed it so, in which case they would on no account have interfered with his appointment, but left me with great satisfaction to perish.

We travelled, on this first day, eighteen or twenty miles, and glad enough I was when, just before sunset, I saw a column of smoke rising out of a small, thick 
wood before me. I forgot my pain at the sight, and hurried on as fast as I was able after Farfar, to seek the protection of a tent where I might rest. By the time I got to the spot, the tents were all pitched, and piles of blazing wood warmed the air within them, and melted away the last snow from the places where large bundles of dry grass were laid to prevent the buffalo skins and blankets from coming into immediate contact with the ground. Faint and exhausted, I lay at length by the fire, and Wa-ki-ta-mo-nee's daughter cut the wet leggings and mocassins from my feet, in order to dry them, and provide them with stronger soles. I was scarcely grateful enough for these friendly attentions, for I was so painfully hungry as to be hardly able to think of anything else; and I gnawed mechanically at a sort of thong of dried meat, never turning my eyes the while from Wo-nes-hee's squaw, who was pounding a heap of maize, with a view of transforming it into a mess of delightful porridge. When I now look back on the eager appetite with which, on that evening, I fell on the huge and not very cleanly mess that was offered me, and consumed the quarter of a racoon to my own share into the bargain, it seems like a dream. I did so, however, and enjoyed my repast not a little; after that, I occupied the remainder of the evening, like the rest of the company, in cracking, between two stones, the hickory nuts, of which the women and children had scratched up a quantity from beneath the snow, and put them into a corner of the tent, so that they might be ready at hand for every one.

Even in an Indian tent, it is possible to have a feeling of hearty content and satisfaction, as I myself abundantly experienced this evening, when I was 
warmed and filled. I lay on my buffalo skins by the bright fire, and really seemed to have no other care in the world than what was occasioned now and then by an unusually hard nut. My feet pained me no more now, and Wo-nes-hee took care that my pipe should never grow cold.

This old gentleman had become more interesting to me since I had been told that he was a ghost-seer, to whom all the departed, both of his own, and of other tribes, were in the habit of appearing at night, and making communications. When the grey warrior used to pull the blanket over his head, and went on for hours together droning in a doleful voice, "Ottoe-Winebag," then, I was informed, the spirits of those were around us, who could find no rest in the happy hunting-grounds, because their scalps had been taken by their enemies. They were showing old Wo-nes-hee their gaping wounds, and bleeding skulls, and calling for revenge; but they did not manifest their presence to any one else. The rest of the party were accustomed to these nocturnal performances; but they did not produce a very agreeable impression on me, though Louis Farfar had informed me of the venerable warrior's "great medicine;" the "medicine," however, lost some of its effects in my eyes, when I had discovered that the worthy old Wo-nes-hee was really half asleep, and was much deceived in the objects around him. I remember, for instance, that he one night declared a pair of leggings, hanging up to dry, were two horses that, in his youth, he might have stolen, and did not, for which neglect of duty he now sang to himself the bitterest reproaches. Another time, it was mentioned to me, in the morning, that a certain scalped 
Missouri chief had been sitting upon me the whole night, and vainly trying to dry his bleeding head at the fire. I replied that I certainly had felt something sitting upon me, but that I happened to know which of the dogs it was.

Wo-nes-hee, however, was not to be disturbed in his opinion, but he said, of course, all men could not be in possession of the same medicine as himself, and that what I had taken for a dog was most unquestionably the scalped Missouri chief.

When I awoke the following morning, I could scarcely stand upon my feet, and earnestly desired to be allowed another day's rest; so I declared myself altogether sick and incapable of travelling, and begged that our journey might be delayed for a day. Had I been accustomed to the Indian shoes, my strength would have held out as well as that of any Red-skin, but with wounds on my feet, I hardly thought I could reach the next encampment. My state was therefore reported to Doctor Wa-ki-ta-moo-nee, who undertook to cure me forthwith; and I beg that you, my dear Doctor Bigelow, will observe his method and apply it to the cure of your own patients. He came to the side of my couch with as solemn an air as a student that has just passed his examination, but instead of feeling my pulse, he began with tremendous energy to knead my stomach; his view of my case being that an evil spirit had got into me, whom it would be necessary by all means to drive from his place of abode. My laughing at this opinion only tended to confirm him in it, and he set to work without delay, secundum artem. Having provided himself with an Indian drum, and a very stout stick, he seated himself by me, taking care to place 
the drum close to my ear, and then began such a stunning rub-a-dub that I almost lost my senses. He also accompanied the drumming with a yelling vocal performance, ranging through the whole scale from the lowest bass notes to the highest treble, till the perspiration streamed down his painted cheeks, and his eyes glared in the wildest excitement. I had hoped by patience and resignation to tire him out, and though my ears were fairly split, I lay quite still, and even tried to make out some of the words he uttered. But I could make out nothing but the everlasting "Hau! Hau!" and Ra-vau-ga-tau-ga, words signifying "Great Mosquito!" that being the appellation with which my Indian friends had honoured me, when they found my name too troublesome to pronounce.

Two mortal hours, or thereabouts, did I endure this torment, but still I found the doctor's patience was by no means exhausted, though mine had been for a long time; but as soon as he noticed my intention to rise from my couch, he increased his musical efforts, yelling horribly, and banging away at the drum as if he would knock it to pieces. The evil spirit, he thought, had now evidently yielded to the influence of the great medicine brought into operation against it, and now only required one more broadside to dislodge it altogether. It was dislodged accordingly; for I crawled out of the tent, determined rather to " mark my path to the Missouri with a bloody trail" than endure any longer this distracting uproar in my ears. Wa-ki-tamo-nee thereupon wiped the moisture from his brow, and looking round triumphantly, declared it was not easy to withstand such a medicine as that, and immediately gave the signal for our departure. The doctor 
had some excuse for claiming credit, for my feet got accustomed to the mocassins, and the wounds healed very soon, so that before our journey was over I was able to keep up with the full-blood Red-skins, in following the track of the elk and the bear. Sometimes we brought a wild cat, and sometimes a deer or a black bear, into the camp, and thus made an addition of a kind of luxury to our daily fare; and every evening we reached a place where there was abundance of wood and water, so that we had little or nothing left to wish for.

The first interruption to our journey was by a day of heavy rain, which spoiled our road, making it excessively slippery, as well as turning the brooks into rushing torrents, and we were at last obliged to make a halt on the wooded banks of one of them, and wait for a change in the weather. We suffered no privation, however, and amused our leisure by cracking nuts; the thaw which had set in, having laid bare great masses of them.

The thaw and rain were succeeded by bright frosty weather, and then we pursued our way; but the ice on the water, by which our path was intercepted, was now not strong enough to bear us and our horses, so that the passage had to be effected in a manner that was rather distressing both to man and beast. On these occasions I became convinced that there is no better labourer in the world than an Indian squaw, as long as she is working for her family, and is only the slave of her husband.

The plan was, after we had relieved the animals of their burdens, to fasten a stout leathern thong or lasso to the jaw of the strongest of them, and another horse to his tail, then another again to his, and so on, till the whole party was formed into one string. When this was done, one half of the men plunged into the water, 
breaking the ice as they went, and carrying with them one end of the lasso to the other side.

I had already, as you may suppose, got pretty well accustomed to cold; but anything like the sensation of emerging from that icy bath in the stiff wet leather clothing, which instantly froze hard, I certainly do not think any one can form an idea of who has not felt it; the cold seems to cut your skin all over as with a knife; you see no possibility of ever getting warm again, but with a kind of desperation seize one end of the lasso with the long string of horses attached to it, and pull away with all your might; whilst the men, women, and children left behind on the opposite bank, operate on the other extremity of the line with blows and pushes, to drive the animals into the stream, from which they at first start back shivering. When they have once been got into the water, however, it is easy to pull them over to the opposite shore, and then the luggage is floated over on masses of ice, packed as quickly as possible on the shaking horses, and away we go again, at a brisk trot, over the dazzling white plain, and do our best to restore the circulation of the blood. Another sharp frost put an end to these troubles, and though it nearly buried us in a ravine by a heavy fall of snow, it improved our road, and built us some good bridges, so that we rapidly approached the mouth of the Nebrasca, and the village of the Ottoes there situated. Our hunts were always fortunate, and I do not think I ever passed on the whole, a more interesting time, than in the latter part of this journey. There were indeed hardships and privations; but a man soon forgets these when he feels how beneficently God's free, beautiful nature acts upon soul and body. I learned to look with pride on my 
ragged mocassins and scarred feet, and to laugh at the icy north wind blowing on my naked breast through the openings of my buffalo skins. I felt in the most joyous spirits, and seemed to be realising the dreams of my youth (dreams conjured up certainly by Cooper and Washington Irving), when I sent a bullet through the skull of a bear, or gave some mighty stag the coup de grace. In the enthusiasm of such moments, I do not think I would have changed places with any man on the whole earth; and when the red-skinned warriors handed me their pipes, and hailed me as the "Great Mosquito! Great Chief!" - Ravanga-tanga, Ka-hi-gatanga, I seemed to be overpaid for all my privations.

We had been travelling four weeks, when Farfar informed me that on this day we should reach the Missouri, on the eastern shore of which some white fur traders had established a small settlement; and he proposed that he should go on before, and fetch some of them to afford me what help they could, and effect my removal from the Ottoes to the Whites, immediately on our arrival. He accordingly set off at a very early hour, whilst I followed with the rest somewhat later, and towards noon we approached the strip of wood that marked the course of the Missouri. We passed the burial place of the Ottoes just before we descended into the valley, and shortly afterwards came to the village. The first consisted of a number of hillocks inclosed by rough palings, and decorated with sticks with little bits of coloured stuff and feathers fluttering from them. The village, which lay not many hundred yards farther, was a group of about sixty huts of various construction, some of clay, shaped like haycocks or baking ovens, others like small houses, built of thick 
oak bark. These dwellings stood mostly empty, as the inhabitants had pitched their tents just now in the angle formed by the Nebrasca and Missouri, on account of the rich grass to be found in these bottom lands under the protecting snow, and because they and their cattle were in that situation more sheltered from the violent gales of wind.

Wa-ki-ta-mo-nee and his household establishment, remained in the upper village, whilst $W_{0}$-nes-hee and his people went down into the bottom ground, and I, before evening, was standing on the ice of the Missouri, making the acquaintance of a Mr. Marten, who gave me a friendly invitation to his abode on the other side of the river.

I accepted the invitation, took leave for the present of my Ottoe friends, and pointed out to them the little log-house in which I was going to stay, and where I hoped to see them all again; the little waggon, with my effects, was pushed over the thick ice, and I soon found myself among friendly white people, who vied with one another in fitting me out with a costume rather more suited to my complexion than that in which I had made my appearance among them. I felt completely transformed, when I found myself in the evening sitting by their warm fireside, eating good bread, drinking a glass of whisky-punch, and entertaining my hosts with the story of my adventures; and I had the satisfaction of remarking that even these rude back-woodsmen sympathised in my sufferings, and rejoiced in my deliverance. I did not, however, remain long with them; but in about a week, went back to the Ottoes, and from them further north, to the tribe of the Omahas, with whom I passed fourteen weeks. During my stay among them, I 
made myself well acquainted with the manners and customs of the Indians of that region, and if it will interest you, I will, on some future occasion, tell you my subsequent experiences at Council Bluffs.

We had proceeded on our way during this narration, and had soon left the herds behind us, overtaken the waggons, and passed them, so that our small party formed the advance of the cavalcade, at a distance of about half a mile. The Indian path we were following, wound across bald hills, ornamented only by low cactus, and made short turns, so that we could not at any time see far before us. On a sudden, we found ourselves in the midst of a herd of superb horses, which, startled by our approach, dispersed in all directions, with raised tails, and open, snorting nostrils. They were tame horses, but without keepers; so that we inferred that there must be an Indian camp in the neighbourhood, and that it would consequently be advisable to ride with caution, and in closer order. At a new turn of the road, we came in sight of a small river shaded by cottonwood trees and shrubs, on the western bank of which was an Indian camp of eighteen large tents. The population seemed as yet to have no idea of the approach of such a considerable body of Whites, since the women and children, mounted on horses without saddles, were cantering carelessly about among a numerous herd that was grazing peacefully at the river side. The sudden appearance of pale faces so near them, produced, however, a change of scene, and the feminine guardians of the herds were replaced by young men, who drove away the cattle towards the Canadian, to place them beyond the reach of visitors whose intentions were as yet unknown to them. In 


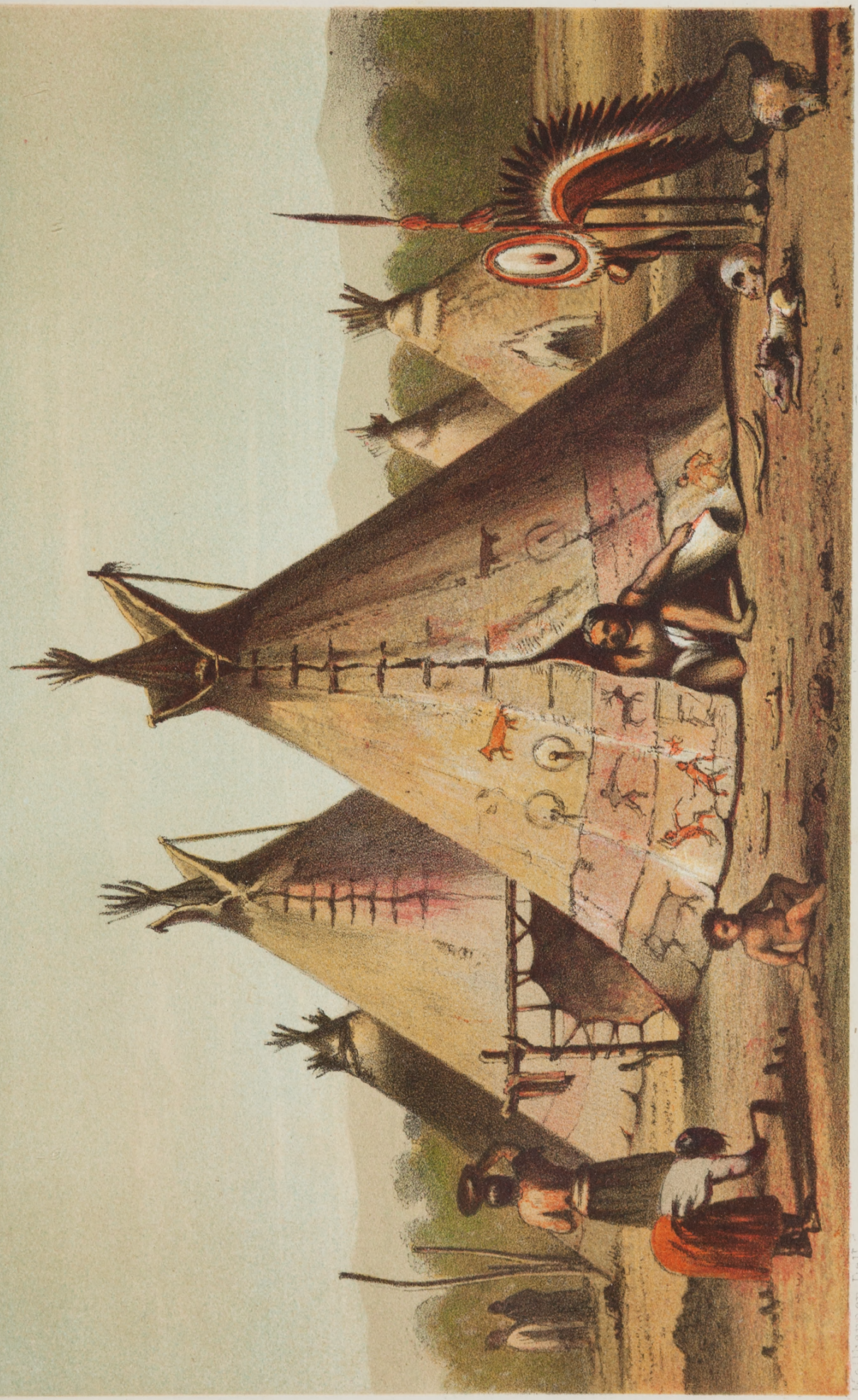



the meantime, the foremost of our party had reached the stream, and seemed to be making preparations to cross it, when some Indians appeared on the opposite bank, and made some very intelligible signs, that our company was, for the present, not at all desired in the village, but that they would come over and make our acquaintance. We signified our assent to this arrangement, and waited whilst the chief and some of his warriors threw the blankets in which their limbs were wrapped over their shoulders, and waded through the water.

When the party reached us, one of them presented himself as Ku-tat-su, chief of the Kioways, and asked, partly by signs, and partly in broken Spanish, for our Capitano.

As Lieutenant Whipple had remained behind with the surveyors and the waggons, a young American who was with us took it into his head to point out Dr. Bigelow as our chief; but $K u$-tat-su, after contemplating attentively the mild-looking, little old gentleman, mounted on a small mule, and without any kind of warlike decoration, seemed to have some suspicion that he was hoaxed, and inquired of the by-standers whether that was really the Capitano. He was assured that the doctor was not only a chief, but a most powerful medicine man; and thereupon the Indian advanced to perform his salutations in due form. He threw back his blanket, opened his arms wide, stepped before the doctor, and embraced him in the most affectionate manner, rubbing his painted cheeks against the other's whiskered ones, according to a custom that seems to have been transplanted from Mexico. The worthy doctor was quite affected by these demonstrations, 
and leaned tenderly towards the savage from Billy's back, patting him on the head and the bronze-coloured shoulders, and exclaiming repeatedly, "Good old fellow!"

This sentimental scene, in which the botanist looked as if he were receiving caresses from a bear, amused us greatly; but it was cut short by the arrival of Lieutenant Whipple, who, after he had been announced as the great chief of all, had to submit to the same compliments. Friendship was now formally established between the high contracting powers, and no further obstacle was opposed to our passage of the river.

A crowd of warriors, old and young, hastily rouged and decorated for the occasion, came out to meet us, whilst others, as we could see through the half open tents, were still busily engaged with their toilettes, beautifying their faces with the indispensable streaks of paint. There was a grey-headed old man among the first comers, who particularly attracted our attention; his costume consisted merely of an American blue blanket coat, much too large for him, but in which, nevertheless, he evidently took no little pride ; and besides the blanket coat, he possessed a wonderful fluency of tongue, which he exerted to the utmost to make a good impression on the Americans. As he had probably heard of the war between the United States and Mexico, he endeavoured in every possible way to make us understand that the Kioways were sworn friends of the former, and that only a small part of his tribe was here encamped, the rest having gone to Mexico to steal horses; and the orator repeated in the most emphatic manner "steal heaps! horses! much horses!"

In compliance with an invitation to that effect, the chief 
climbed into a small waggon that served for the transport of the instruments, and drove on first with it, in order to make his entry into the village in this triumphant manner; showing great anxiety that all his people should see him; and they did not fail to testify the due amount of admiration at the imposing figure he made.

We stayed only a short time at the Indian village, and then betook ourselves to a spot some hundreds of yards further West; where, according to our agreement with the Indians, we were to pitch our camp for the night. The most distinguished of the warriors were then to come and have a talk with the Whites; in order, since they saw there was nothing to be got from us by force, to try and levy a small tribute by coaxing and begging. Ku-tat-su (the sorrel horse), accompanied by three of his braves,-large, powerful men, rejoicing in the appellations of Pat-soot-koe-cat, Jasa-sora and Tu-ga-sone, all, like their chief, considerably advanced in life,--presented themselves accordingly before the tent of Lieutenant Whipple, painted and decorated in every conceivable manner known to Indian art. The chief wore on his head a splendid plume of eagle's feathers, whilst his warriors, though their long black hair was uncovered, had their scalp locks ornamented with strings of round pieces of tin. In the painting that covered their faces and the upper parts of their bodies, a special partiality was exhibited for yellow colour, and great numbers of brass rings were worn on their arms, neck, and ears. In this full dress style they entered the tent, where the commander, and some of the members of our expedition, were awaiting them, with the little interpreter Vincenti.

The pipe first went round, and then Lieutenant

$$
\text { P } 4
$$


Whipple addressed his guests, through Vincenti, in the following words :-

"Our great grandfather in Washington (the President of the United States, has sent us to travel very far towards the setting sun; we are to go as far as the great water, and to visit all his red children; we are to travel through the lands of the Kioways, and smoke the pipe of peace with them; we are to see whether the Kioways behave like friends and brothers of the Americans; if they murder no travellers, and steal no horses, we are to make them presents. But if the tribe of the Kioways are bad people, and ill-disposed, then the great grandfather in Washington will send as many soldiers as the Kioways have horses, and great thick guns (cannon) besides, and will destroy the whole nation to the last man."

This speech, though not very ceremonious, was well suited to the Kioways, who have been known for years as the most treacherous Indians of the steppes, and have several times fallen upon lonely settlements, and after plundering them and murdering the men in the cruellest manner have dragged away the women and children into captivity. Lieutenant Whipple had been informed also by four Mexican barter-traders, who had fallen in with the Kioways about the same time as the Expedition, that this small band of Indians had with them two Mexican prisoners, and he wished to intimidate the savages, in order to effect the deliverance of the Mexicans the more easily.

These prisoners were a young man and a woman, who had been stolen as children, and had lived ever since with the robbers, and it was found that the young man had become a complete Indian, and was only to be 
distinguished as of Spanish origin by his curling hair. He retained but just enough of his native language to be able to declare that he had no inclination to change his present position for any other. The woman did, however, declare that she would like to go back to her home, although she had become the wife of Ku-tat-su, and the mother of a young chief. Under these circumstances, it seemed likely that all efforts to procure her freedom would be vain; but nevertheless it was determined to make the attempt.

The Indian chief answered the address of Lieutenant Whipple in the following manner:-

"The speech is good, but the great grandfather does not love his red children, or he would have said to those who were coming through our village, first give the Kioways presents, and then talk to them."

To this rather impudent expression of opinion, Lieutenant Whipple replied, that it was his plan to talk to them before he made them presents; but that in order that they might all see with what friendly feelings the Americans had come among them, he would now distribute a few things, and then talk further. Hereupon he produced some glass beads, red paint, knives, tobacco, and blankets, and then the conference went on. As usual, the Kioways declared themselves most excellent friends and brothers of the Americans, although they were unquestionably at that moment mourning in their hearts that their present visitors were in too great force to be either scalped or plundered.

The request to release their prisoners was declined without a moment's hesitation; the most splendid presents could not induce the old chief to give up his wife and child, and the wife, on her side, would not leave the 
Indian unless she might take her child with her. The conversation was therefore brought to an end, and Lieutenant Whipple presented the community with a cow, to make a feast, in the name of the great grandfather in Washington. The creature was immediately killed with arrows, cut up, distributed, and eaten by the savages in an incredibly short space, and red skins and pale faces then mingled indiscriminately in the two camps, and carried on commercial interchanges of buttons, buckles, coins, and so forth, for buffalo skins and embroidered mocassins, and it was not till sunset that the visitors on both sides were requested, for the sake of public security, to withdraw to their respective domains.

The Kioways are little distinguished in external appearance, character or manners, from the Comanches, their nearest neighbours, with whom they have their territories in common: and yet there is not the smallest likeness to be discovered in the language of the two nations, and they can only understand each other by means of interpreters, unless they have recourse to the speech of the Kaddo Indians, a tribe living farther south, or to what may be called the general prairie language. The first is generally understood sufficiently by both to serve as a medium of communication; and the second consists almost exclusively of signs, but is intelligible to all the Indians of the steppes; while at the same time it enables the white traders to hold intercourse with them.

The Comanches, as well as the Kioways, greatly resemble in their manners and customs the nomadic nations of the old World. They are governed by a chief, whose authority lasts no longer than the general 
consent. He is the leader in war and the chief in the council; but, should he be guilty of any act of cowardice or of bad administration, he is immediately deposed from his supremacy, and another more capable chief chosen in his stead. The laws of the Kioways correspond entirely with their peculiar position, and are made valid by the will of the whole tribe, and exactly and rigidly put in force by the subordinate chiefs.

Their ideas on the rights of property are very peculiar, theft being regarded as not only allowable but highly honourable; so that it is not surprising if more determined thieves cannot be met with anywhere than among these tribes. To punish them for these robberies would be a very difficult task indeed; for as the prairie Indians are accustomed from their earliest youth to the use of arms and horses, and have no settled villages or fixed places of abode, it does not occasion them the smallest inconvenience to be suddenly compelled to transport themselves and their whole possessions, from one end of the buffalo region to the other. They are in possession of immense numbers of stout horses, so that they are able to move with the greatest rapidity; and their exact knowledge of the locality, and of the places where water is to be found, of course affords them great advantage and facility of escape from pursuit. A war would by no means entail the same misery on them as on tribes with more settled habits; and it would even be of little use to try to cut off their usual supply of food, since their herds of horses and mules would afford them subsistence for a long time. They know perfectly well too, that they are very difficult to get at, and the knowledge only renders them bolder and more dangerous. 
They are, like all Indians, very superstitious, believing much in dreams, carrying medicine bags and amulets, and endeavouring to propitiate the favour of invisible spirits by sacrifices, dances, and music. The existence and power of one great Supreme Being, the guide and ruler of all things, is acknowledged by them as it is by the Comanches, and they worship the sun as his symbol. They believe also in the continued existence of the soul ; but they assume that the future life will be precisely like the present; and bury with the deceased warrior his weapons of war and of the chase, that he may make his appearance in a creditable manner in the fields of the blessed.

No attempts have yet been made to raise these savages to any higher degree of physical or moral culture, so as to lay the foundation for civilisation and Christianity; for the pious men of America look with indifference on the heathens before their own doors, but send out missionaries to preach Christianity in the remotest parts of the world. When, through the covetousness of the white civilised races, the free inhabitants of the steppes shall have been ruined and exterminated, Christian love will find its way to their empty wigwams, and churches and meeting-houses rise over the graves of the poor, victimised, legitimate owners of the green prairies.

The night passed without the slightest disturbance, in a quiet that could hardly have been expected in the neighbourhood of this dishonest tribe; but early the following morning the Indians made their appearance; they had come to witness the departure of the Whites, and to watch for opportunities of confiscating missing or forgotten articles, that might be left on the place of 
encampment, just as the wolves watch for the departure of the last man of a travelling party, in order to slink round the decaying fire, and pick up whatever waifs and strays are to be had.

Our road to the West was cut off by high sand-hills and marshy hollows, and it was therefore resolved to turn back, pass again through the village of the Kioways, cross the shallow Canadian, and pursue our prescribed route on its northern side.

The ground was very uneven, and it became so difficult to get on with the waggons, that we all desired to return to the southern bank as soon as ever the sandhills were out of our way; but on recrossing the river an accident happened that, as it chanced, only occasioned a hearty laugh, though it might easily have been no laughing matter either for Dr. Bigelow or his Billy.

In order to find out a suitable place for the waggons to cross, I and the doctor had ridden on to a part of the river where a broad island promised to facilitate the operation, and between which and the shore, not a drop of water showed itself above the damp sand, so that, as Billy's master declared, under his guidance, no mule of the whole expedition need no much as wet his hoof. Scarcely, however, were we a hundred yards from the shore, when our mules' hoofs were considerably disturbed by the ground beneath them beginning evidently to undulate. Perceiving the nature of the danger, I urged on my beast as quickly as possible, and made it describe a wide circuit, so as to distribute the weight of the two animals over the dangerous ground, and after a short struggle, I reached the shore in safety. The doctor at my warning cry attempted to do the same; but at every step the deceitful sand assumed a more glittering ap- 
pearance, water showed itself more and more, as the surface yielded to the weight of the rider, and at last the struggling mule fairly broke in, and was fast sinking. Fortunately one of the violent efforts made by Billy, flung the doctor far out of the saddle, upon the bank, and the animal, now freed from the burden of his rider, managed by the exertion of its utmost strength, to disengage itself, before the sand had completely swallowed it up, and made for the shore, where its master was now awaiting it; but both man and mule bore on their entire persons the signs of the intimate acquaintance they had formed with the brick-dust coloured sand of the Canadian. The zealous botanist, however, thought as little of his costume as of the danger to his person; his anxiety was wholly for the specimens which he carried in a leathern case. He opened it in much fear, but after glancing in, exclaimed, "Well that is fortunate! not a single drop of water has got in ; if it had it would have completely spoiled a most valuable specimen of a cactus." It is hardly necessary to add that a different part of the river was chosen for the passage, and one in which clear water rippled over a firm bottom, instead of being lost in the treacherous sand. 


\section{CHAP. XII.}

FURTHER PROGRESS OF THE EXPEDITION UP THE CANADIAN. SHADY CREEK. - SUMMER DWELLINGS AND MEDICINE TENT OH THE COMANCHE INDIANS. - A FANDANGO IN THE STEPPE. PUEBLO INDIANS. - OPUNTIA ARBORESCENS. - THE RELATIONS BETWEEN THE MEXICANS AND INDIANS. - INEZ GONZALES. BEAUTIFUL VIEW CREEK. - EL LLANO ESTACADO.

For several days our route lay along the Canadian; patches of deep sand hindering our progress occasionally, when the expedition was compelled by the windings of the river to force its way between the sand hills. Southward of the road, the remains of the elevated plain were more frequent and more connected, and the springs gushing out at their foot united to form brooks, which rippled along briskly towards the Canadian, sometimes wasting their treasures on thirsty, hot, ungrateful soil, at others moistening the roots of trees and shrubs growing luxuriantly in the more favoured spots.

After journeying for a long time over hard flinty ground, and at most seeing shady groups of trees only in the blue distance, it is so delightful to find yourself suddenly and unexpectedly at the entrance of a deep valley, with dark woods and green meadows, and a copiously supplied rivulet murmuring through them, that it is not in human nature to ask, "How many miles ought we to do to-day ?" or, "Is it time to halt?" Who could help setting his beast at liberty at once to 
enjoy the fresh grass, and rushing down to the water to enjoy himself?

Thus it was with our expedition, when we turned from the barren heights into the valley of the Shady Creek, and rejoiced our eyes with the rich and lovely landscape. The sun had not yet reached its meridian height, and a deep tranquillity brooded over wood, and stream, and meadow, a tranquillity that was in no wise disturbed by the presence of hundreds of leafy bowers, which had been constructed with boughs by the Comanches for their summer dwellings. They were now empty and forsaken, but not desolate, for the mocking-bird was sitting between the dried leaves and singing merrily to the world in general ; the prairie cocks were hopping about through the dry twigs, and ravens playing with gnawed bones and bits of leather in front of the huts. The savages, it seemed, had, like ourselves, found pleasure in this valley, and passed here the first months of summer; but the wandering buffaloes had enticed them away and led them towards the north. The wild commotion of buffaloes and their pursuers had now passed away, but the valley lay fresh and green before us ; and only a few minutes after the arrival of our expedition, groups of people were again wandering about, and flocks and herds scattered through the woods and meadows in all directions, the bustle driving the thrushes into the thicket, the prairie hens into the tall grass, and the croaking ravens high up into the arid plain.

The Indian summer dwellings excited general attention; and no sooner were our tents pitched than each man hurried out again to examine more carefully these tabernacles and spy about for lost or forgotten articles, as the Indians do at our camping places. 
The dwellings consisted of green boughs stuck into the ground opposite one another, and twined together at the top, so as to form long arbours, not high enough, however, to admit a man, except in a recumbent or crouching position. Before every arbour was its kitchen, traceable by a heap of ashes in a hole, and this completed the simple habitation. The medicine huts, however, were not wanting ; they were placed on the banks of the brook, and formed in the same manner as the other huts, only on a smaller scale; within them were two heaps of stones, surrounded by little trenches, and before the entrance was a fire-place for heating stones. In almost all diseases, the Indians make use of these medicine tents for a somewhat rough kind of vapourbath, which is managed in the following manner: After the hut has been closely covered in with skins, and redhot stones heaped up inside, the patient enters and places himself between the two heaps, over which water is then poured. The narrow space is immediately filled with hot vapour, which causes perspiration; and when the heat has reached the highest point, out rushes the patient, and plunges into cold water. This process is repeated several times according to the strength of the sufferer; it is probably well adapted to the Indian constitution, for it is usually followed by the best consequences. Of course a medicine man is at hand to watch the bath, and there is no lack of healing songs and enchantments. Besides sick people, young men desirous of entering the ranks of the warriors resort to these baths; and sometimes old warriors also, when about to set off on some warlike or predatory expedition.

The four Mexicans who had joined us at the camp of the Kioways, and had not enjoyed the best treatment 
from the Indians, having even lost some of their weapons, were now travelling under the protection of our Expedition. A few Pueblo-Indians from St. Domingo and the Rio Grande, crossing the steppe for purposes of barter, had also joined, and kept even pace with us, intending to separate from the Expedition at Shady Creek, and proceed in company with the Mexicans, in longer marches towards their home on the Rio Grande. The two helped us, one fine night, to get up a grand fandango on the steppe. About a hundred yards from the waggons, the goods of these Mexicans and PuebloIndians were lying scattered about in a semicircle; the moon shone brightly down on the vast plain; all was still, except that there now and then came from afar the howl of a prairie wolf, faintly heard in our camp, where men of various races were sauntering negligently about. The beauty of the night seemed somehow to awaken the music in the soul of an American waggoner of our party; and having found himself the highest and most convenient place he could on the top of the luggage, he brought out an old cracked fiddle, which he had laboriously conveyed from his distant home, and began to draw from it some extraordinary sounds. The shrill notes, however, no sooner reached the ears of the company, than a crowd gathered round the amateur, who, proud of the sensation he was producing, worked away more and more vigorously upon the dusty, jangling strings, negro melodies, alternating with "Hail, Columbia!" and "Yankee Doodle." Those were tunes that found their way straight to every man's heart.

Logs of wood were flung on the fire to make a fresh blaze, and bearded Americans, yellow descendants of Spain, and half-naked Pueblos, all armed from head 
to foot, and in attire that bore the marks of long and painful travel, began to foot it as if possessed.

Here two long Americans seized each other, and jumped and whirled round together in mad circles; there a Mexican was seen waltzing with an Indian; on one side were two Kentucky men performing an energetic jig, and a little way off two Irishmen, in the uniform of the United States infantry, were working away enthusiastically at a national dance, and shouting "Ould Ireland for ever!" and, "Oh if we had but plenty of whisky!"

Even the sentinel leaning on his musket grew sentimental and musical, and murmured to himself,

"J'aime à revoir ma Normandie !"

while the musician, from his lofty throne, looked calmly down on the commotion, and fiddled away unweariedly, triumphantly remarking, that all the dances in the world might be danced in time to his tunes; and the songs of every nation on the earth carried on amicably together. He played through half the night, till a thick cloud of dust hid his face and his violin, and the exhausted dancers sank down beside their luggage, or betook themselves to their rest, to try to gather, from a few hours' sleep, strength and spirit for the march of the following day.

A more peaceful race of people than the PuebloIndians, who joined so merrily in this mad revel, is hardly to be imagined. They are always friendly and obliging to strangers, wherever they may meet them, and show the greatest hospitality to those who visit their dwellings. Many populous Indian towns still 
flourishing in New-Mexico contain but a remnant of this once powerful and wide-spreading race, traces of which are to be found in all directions, from the Rio Grande to the great Colorado of the West. Having been now for some time in habits of frequent intercourse with the Mexicans, their manners as well as their costume have become much modified, and the greater part of them have mastered the Spanish language. Industry is one of their leading virtues; they cultivate their fields and gardens, and often take journeys to visit the wild Indians of the steppe, in order to exchange their wares for skins and furs; and travellers approaching the borders of New Mexico often meet little caravans of Pueblo-Indians, driving their well-laden asses and mules briskly over the plains.

As soon as our Expedition had left the valley of Shady Creek, and toiled up again between rough hills. and blocks of sandstone towards the plain, we began to perceive traces of a change in the vegetation. Here first showed itself a new species of cactus, the Opuntia arborescens, growing in great luxuriance. The short stem rose from the ground like a dwarf-tree, and then separated into branches and boughs, which spread themselves out in a crown, bearing, besides innumerable thorns, a quantity of yellow seed-vessels.

After this time we travelled no more in the valley of the Canadian River ; but, turning away from it, approached the eastern end of the Llano Estacado. The plain spread out before us desolate and dead, the unfruitful soil was scantily grown with Gramma-grass, and the beautiful cactus, which takes thankfully the poorest food and hardest fare, was found blooming alone. We crossed Red Bank Creek, whose red shores offered 
not the slightest trace of vegetation, and we all longed to reach Beautiful View Creek, that the prospect we anticipated might make us amends for all our privations. But we had still a long way to go before reaching it, and as the surrounding country was so little attractive, and no living thing except the prairie-dogs and the burrowing owl was to be seen, we were all anxious to wile away the time with conversation. "Mr. Whipple," said one of our company to the commander of the Expedition, "could we not have taken away the young Mexican woman by force from the Kioways, to send her back to her home?"

"We could, certainly," was the answer, "as the power was on our side, but we should certainly then have been prevented from carrying out our Government instructions. Our journey as far as the Rio Grande would have been one continued fight; the Indians would have swarmed about us like bees, and hindered our work, and the whole object of our journey would have been frustrated. We are instructed to make precise observations as we go, and not to make war on Indians, and we are pretty sure to be obliged, some time or other, to use our weapons against them in self-defence, without manufacturing a casus belli for ourselves, especially where we can't be sure of having any other right than that of might. Of course, we shall make the thing known as soon as we arrive in New Mexico; but I hardly think that any attempt at rescue will be made. The relations between Mexicans and Indians are very complicated, and it is probable that there are not fewer of the former in captivity amongst the Indians, than there are Indians who have been made slaves of by Mexicans; the savages have however taken their pri- 
soners themselves at the peril of their lives, while the Whites obtain by traffic Indians who have been made slaves by others, partly for the sake of using their labour, but partly also that they may sell them again, in case they should prove rebellious or useless. In this way the Mexicans often enough buy back their captive countrymen ; but the position of the captives is not much improved by the change; for they remain the serfs or peons of their new masters, until they think proper to sell them again to neighbours or countrymen in other provinces. The treatment the women receive in these cases," continued the lieutenant, "is most infamous. I had myself an opportunity of observing closely one such instance, when I held an appointment some years ago in the Mexican Boundary Surveying Commission. I will tell you what I was myself witness of, and what was told me by Mr. Bartlett, also one of the United States Commissioners. Dr. Bigelow, too, was a member of that Expedition, and can bear witness to the truth of my account. We had established a permanent camp near the copper mines of New Mexico, and carried on our observations and works from that point. We were there on tolerably friendly terms with the Apache Indians, who surrounded us in great numbers, and we were also frequently visited by caravans of Mexicans who traversed the country, carrying on a very doubtful kind of traffic. One evening a party of these had come to the camp, bringing with them a herd of mules and horses, and also a young girl ; some of them wished to obtain provisions from us, and in the course of conversation it appeared that they had got both the cattle and the girl from the Indians, and were conveying them to a northern town of New Mexico, to get as good a 
price as they could for them. Since the commanding officers of the Expedition were bound by the treaty to effect the liberation of all prisoners with whom they came in contact, and send them home, they immediately took measures to get the poor girl, who declared herself a Mexican, out of the hands of her cruel countrymen; and with this view they required the three Mexican traders to give an account of themselves. These men belonged, according to their statement, to a caravan of about fifty who carried on traffic with the Indians to the north of Gila. About thirty of the party had remained behind, and the rest were returning in the way of their business to Santa Fé, whither they intended taking the young girl, whom they had obtained, they said, from the Piñol Indians. By this account it appeared they were going in the very opposite direction to that which they should have taken, had they intended to restore her to her friends at Santa Cruz; so that it was evident that the young prisoner was destined to be made a slave, and sold like any other of their wares.

"Referring to the treaty as his warrant, the commanding officer declared to the traders their firm resolution to detain the girl, and subsequently send her back to her friends, but, until then, to treat her with all possible hospitality. The opposition of the traders, their deceitful assurances of honourable intentions, were all in vain ; the girl remained with us in the camp, and her circumstances had awakened such general sympathy, that the rudest of the labourers was never guilty of the slightest disrespect towards her.

"Iñez Gonzales was the daughter of Jesus Gonzales of Santa Cruz, a little frontier town on the San Pedro river, in Sonora; she had scarcely attained her fifteenth 
year, was most pleasing and interesting in appearance, and very winning and modest in her manners. In the September of the preceding year, she had left Santa Cruz, in company with her uncle and aunt, another woman, and her young son, in order to attend the Festival of St. Francis, at the town of Magdalena, about fifteen miles off; and as a protection against the vagabond robber Indians, the party had been furnished with an escort of ten soldiers. On the second day of their journey, their way lay through a ravine, watered by a stream, with thickly wooded banks, and in the middle of this ravine was a rough wooden cross, erected to the memory of some Mexican who had been murdered there.

"When the travellers reached the cross, they stopped to say a prayer for his soul, and while they were thus engaged, there arose suddenly a wild yell from the neighbouring thicket, and out rushed a band of bloodthirsty Piñol Indians, threw themselves on the unsuspecting travellers, and shot, or pierced with their lances, seven of the soldiers, as well as the uncle of Iñez. The remaining three made their escape, to tell the tale of the fate of their comrades, and Iñez, her two female companions, and the boy, were dragged away as prisoners. The three latter were soon bought, and carried off as slaves to the northern settlements, whilst Iñez was kept with the Indians until they met the Mexican traders, to whom she was made over. She had been obliged to work hard, and most of her clothing had been taken from her, but she had not been otherwise subjected to bad treatment.

"The Piñol or Piñoleno Indians are a tribe of not more than 500, who haunt the extensive district between the 
Sierra Piñol and the Sierra Blanca, two mountains lying very near the Upper St. Francisco river.

"The food consists chiefly of the Agave Mexicana, from which they prepare a kind of bread; all else they procure by robbery, and their desire for making prisoners arises from their being able to dispose of them advantageously to the Mexicans, who are thus indirectly the accomplices of their outrages. Iñez knew of more than twelve men and women who, during her stay with the Indians, had been brought in as prisoners, and who had all shared the same fate.

"Our fair captive received every possible attention from us, and every member of the Commission exerted himself to render her stay among us as tolerable to her as possible. She was as well dressed as the means at our disposal in the camp permitted, and received an abundance of presents; she used to employ her time in needlework, and the reading of some Spanish books which happened to be found among the company ; but the melancholy expression of her pretty face showed that she was still longing for her home and her friends. At last we left the copper mines, and our business had carried us southward to a place not far from Santa Cruz, when one day happening to be in want of meat, we sent two of our men to a settlement to get some sheep. They followed for a whole day the course of the San Pedro river, and then came to a party of thirty Mexicans, who had come out to hunt wild cattle, and to them they mentioned our intention of going to Santa Cruz, and told the story of the rescue of pretty Iñez. The story created a tremendous sensation, for the father and uncle of Iñez were among the party, who were all from Santa Cruz, and all acquainted with her more 
or less; they seemed scarcely able to believe that she was safe, and their herds of cattle were immediately left to the care of a single man, whilst all the rest set off for our camp.

"It appeared to be something quite unheard of that a girl who had once been stolen by the Indians should ever return; and the joy of her father, and the friends who had believed her irrecoverably lost, was quite indescribable. One after another ran up to embrace her, and tears rolled down the faces of the half-naked sunburnt fellows, whose emotion almost deprived them of speech. The girl threw herself sobbing into the arms of one after another, and seemed for some time incapable of asking after her mother, and her brothers and sisters; and when she did, the announcement that they were all well, brought another burst of tears, but this time, I suppose, only tears of joy. There was not one of our hard weather-beaten workmen who was not affected by the scene, and those who had brought about this happy meeting felt themselves most richly rewarded. When we got to Santa Cruz, two of the Mexicans ran on to inform the mother of the rescue of her daughter, and prepare her for her speedy return; but the mother could not wait for our arrival in the town, but came out with a number of friends and relations to meet us. As the procession approached, and Iñez recognised her mother, she sprang from her horse and rushed towards her ; and from the loud and hurried exclamations of joy poured out by both, we could imagine the pain they must have suffered from their separation. The mother embraced the girl again and again, and seemed only to release her from her arms that she might gaze upon her, and convince herself of the reality of the restoration. New acquaintances came in every moment to welcome 
her, and also two young brothers, who scrambled up upon her horse, and expressed their joy in all kinds of boyish tricks. Another boy, however, walked by the side of the horse, with tears rolling down his brown cheeks : his mother had been stolen, and nothing had ever been heard of her; he had no other part, poor fellow, in the day's joy, than consisted in looks of the deepest sympathy and compassion. The scene altogether was almost too much for us, and we proceeded slowly on our way. I have often since thought of the circumstance, and have never been able to reconcile what I there saw of the deep feeling of these people, with the fact that there exist among them wretches who, for the sake of a little lucre, will trample on the domestic happiness of families ; and I could hardly help persuading myself, that if those who had intended to sell Iñez to slavery could have witnessed her return, they would for ever have abandoned their atrocious traffic. From the mere savages of the country, this can hardly be expected; but if, instead of using them as but too willing tools for all sorts of shameful purposes, the Whites firmly and boldly opposed their vices, slave robberies would decrease, and the Indians, finding this source of profit cut off, would be more inclined to adopt a civilised mode of life.

"But you should hear the sequel of the tale of Iñez. She had, after all, poor girl, a deplorable fate, which was chiefly to be attributed to the weakness of her relatives, as well as to the low grade of culture among these people, which allows them to submit to every insult from the officers of the army.

"When we passed through the town to pitch our tents, which suited us better than the Mexican Adobe houses, on the other side we saw Iñez and her relatives at 
church, thanking God and all the saints for their reunion; and we took leave of them, not supposing that we should ever hear of them again, for our business called us in another direction. We all remembered our pretty captive, however, and a day seldom passed in which one or the other did not mention her.

"About half a year had passed since the incident I have mentioned, when we had occasion to go to Tubac, a Mexican military post in the neighbourhood of Santa Cruz, where a few tumble-down houses and clay hovels were provided with a feeble garrison, commanded by a certain Captain Gomez. Imagine our astonishment when we learned that Iñez Gonzales was in this man's company, and in his power. We demanded an explanation from him, and he stated that she was certainly there, but that her mother was with her, and they were going back together. He consented, though very reluctantly, that we should have an interview with the poor girl, and she seemed greatly rejoiced to see again her old travelling companions, but appeared nevertheless very dejected; and this Captain Gomez, who would not lose sight of her, was evidently connected with her dejection.

"When we asked if she would go back with us to Santa Cruz, she answered, hesitating and evidently in fear of her master, that she would do as he pleased; and he gave us his solemn promise that the girl and her mother should follow us the next day. We left the place, but when we got to Santa Cruz, all we could learn about the matter was, that Gomez, who had by an artifice enticed them to Tubac, had afterwards sent back the mother alone.

"There was only one thing more that we could do;- 
Mr. Bartlett wrote to Cubillas, the governor of Sonora, and tried to interest him in the fate of the unfortunate Iñez, but what was the result of this step we could never learn. We returned to the United States; one went here, and another there, and many a year will probably pass before any one of us will go that way again ; but I will answer for it, none of us have forgotten poor Iñez, or failed to wish her a better lot."* "Yes," exclaimed Dr. Bigelow, "and to think how much they should like to send a bullet through the head of Captain Gomez; but he belonged to the State of Sonora, and we had no jurisdiction over him; and besides, if all crimes of that kind were punished with death in those countries, half the population would be cut off."

Lieutenant Whipple and his companions had now arrived at the entrance of the spacious valley known as Beautiful View Creek, and the party stopped to see how far it deserved its appellation. "In the state of New York, or in the district of Columbia,". said the commander, "such a view as that would attract very little notice; but it is an agreeable surprise here, though the valley does not seem to be much more fruitful than the steppe we have been crossing."

It was as Lieutenant Whipple had said. Across a broad valley, the eye followed the course of a stream that hastened, in short windings, to the Canadian. The valley was enclosed by the broken and fantastically formed remains of the high plain ; the club-shaped hills that projected far into the valley, or sometimes fell back

* In "Bartlett's Personal Narrative," may be found further particulars. 
from it, formed a curious perspective, and the reddish colour of the soil, on which crippled cedars grew at almost regular distances from one another, heightened the peculiarity of the landscape. Many of the ravines, regarded separately, presented a wild chaos of blocks of red and yellow sandstone, dark-coloured cedars, and sandy soil, on which scarcely any thing but the modest cactus was able to strike root.

We easily got our cavalcade down into the valley, and across the small river, and we then began to move along the edge of the Llano Estacado, whose grotesque clefts and chasms filled with cedar penetrated far into the plateau, and cut off from it masses like gigantic walls and fortresses.

As the waggons approached this table-land, the unevenness of the ground increased, but the pace of the animals was nevertheless accelerated in order to reach a certain ravine with a spring, which lay on our route, and which was to be the goal of this day's journey.

The road through the prairie was certainly more convenient than that on which the Expedition now found itself; but we worked our way cheerfully from hill to hill, and the eye continually rested on new objects in the landscape in which it could take pleasure. Antelopes were springing about on the dry hills, deer lurking behind the blue-green cedars, eagles and kites wheeling their flight through the air, and lively little prairie dogs, peeping out and giving tongue from the openings of their dark abodes.

After passing through some majestic scenery with towering masses of grey rock, like frowning fortresses, and wild dark ravines, we found the spring we were in search of, and pitched our camp (on the 16th of Sep- 
tember) near a natural vineyard, which offered us an abundance of fine grapes. Since leaving Fort Smith, we had traversed 564 miles in a tolerably straight line, over smooth and rolling prairie, and we had imperceptibly risen to a considerable height. Fort Smith lies only 460 feet above the level of the sea ; the second remarkable point, the Antelope Hills, or boundary hills of Texas, 2100 ; while in this camp at the foot of the lofty plateau, we found ourselves at the height of 4278 feet. The lofty plain called el Llano Estacado, or Markedoff Plain,* which extends over four degrees of latitude and four of longitude, reaches, at certain points, a heigh of 4707 feet, and the average elevation is reckoned at 4500 , therefore 222 feet reckoned above the base. The soil is sandy, and horizontal beds of red and white sandstone extend from one end to the other. A very small part of this vast plain is yet known, for travellers shrink from penetrating into regions where they would be liable to perish from want of wood and water, and the ascent to it is so troublesome, that they are not very willing to cross a corner of it, to avoid a wide and laborious circuit. The tract which Lieutenant Whipple and his party had to pass was twenty-seven miles across, consequently a good day's march; and though Encampment Creek was to be touched on in the course of the day, it was easy to foresee that it would be dry; and we therefore determined to make the ascent of the plateau on the following morning before sunrise, to rest for an hour at Encampment Creek, and then, with renewed

* On this plateau there is nothing whatever that could serve the traveller as a landmark; and the Mexican traders of former times have planted long poles in the ground, at certain distances, to show the best way across it. Thence the name, el Llano Estacado. 
strength, to hasten on to Rocky Dell Creek, the western boundary of Texas, and at that point to descend again from the dreary plain. The cold evening air, and the prospect of a long march before us, induced every one to wrap himself in his blankets at an earlier hour than usual, and betake himself to his night's rest.

The moon had just set, and darkness had succeeded to her mild and pleasant light, when the signal for departure was given. Men still half asleep rose from all quarters of the camp, and came crowding to the halfdecaying fires, for the night was excessively cold. Impenetrable blackness lay on the ravines and valleys, but the towers and walls of the plateau soon began to loom out faintly and mysteriously against the dark grey sky; and when it was still two hours before sunrise, the first faint dawn in the East announced the approaching day, and broad white shafts shot upward to the zenith, dividing the whole firmament into regular spaces, so that it was easy to calculate, from the direction of the outer shafts which were inclined north and south, how far the sun must be still below the horizon. It was as yet no true dawn; for the beams at first sent out no light, but, on the contrary, made the sky appear, from the contrast, a still darker grey. By the time the beams had assumed a reddish tint, and began to diffuse a gradually increasing light, our camp fires were nearly extinguished, and the hungry wolves were wrangling over the remains of our morning meal. Single horsemen were first seen ascending the plateau, and then the waggons rolled briskly one after another up the steep ascent. When they were once at the top, their wheels bowled along easily over the smooth surface, and the cattle seemed scarcely to make an effort to 
draw their heavy loads after them. A dazzling splendour in the east now drew all eyes in that direction, and then the darkly glowing sun rose out of the Llano Estacado, just as he does from the boundless ocean, when the wild waves sleep, no breath of wind disturbs the glassy surface, and a line of light stretches from the sun to the observer. The line of light was not wanting on the Llano, but it was reflected not from a glassy surface, but from millions of drops of dew, that hung profusely on every leaf and blade of grass. At sea the first thing you do is to look round the horizon for a sail, and to rejoice if you discover one; you feel less forlorn then in the sublime solitude; but in the Llano you would seek in vain for such a consolation; no tree or shrub breaks the monotony of the plain ; and while the ocean does but seem to sleep, and its heavings, like the breathings of a leviathan, show it to be still alive, the Llano Estacado is dead, and varied only by the deceitful mirage. 


\section{CHAP. XIII.}

CONTINUATION OF THE NATURALIST'S STORY.- ENCAMPMENT CREEK. - JOURNeY ACROSS THE Llano ESTACADO. - ARRIVAL AT ROCKY DELL CREEK. - INDIAN PAINTINGS.

"I Don't believe you will have any better luck than I have had," said Dr. Bigelow, throwing the reins on the neck of his mule, and making some vain attempt to beat his ancient and much worn hat into something like its original shape; "I have been riding about for an hour, and I have not found a single plant worth the trouble of taking, and as I have seen no living thing in the meanwhile but some grasshoppers and an antelope, or rather the shadow of an antelope on the distant horizon, I think it likely that your hunt after snakes and lizards will not be more successful than my botanising."

"Truly nature does seem to be dead," replied the person addressed, "and if you look along our whole line, you will see that her lifeless aspect has an influence even on the roughest of our labourers; they all seem to be moving along half asleep, or like so many machines."

"The influence of nature upon the mind of man," said the Doctor sententiously, "is irresistible, but I myself never become the victim of ennui as long as I can move freely about in God's beautiful world. Nature is not dumb, she speaks to us and affords a beautiful, 
noble entertainment to him who understands her language. Even the dry withered grass that crumbles to dust under the feet of our mules, has something to say, but I must own that up here, where not so much as a cactus can take root, I rather prefer conversing with my fellow men: so do you," continued the doctor, turning to him who had entertained the company with his adventures among the Indians; "do you go on with your story from where you took leave of Mr. Marten, and went back to the Ottoes. We all want to know what happened to you afterwards."

"With all my heart," was the reply, "I still think of those times often enough. Well, I found myself, as I said, once more among white men, and in the enjoyment of luxury unknown to the West. I slept in a rough wooden bedstead, I took my meals at a table, and moreover I sat on a chair, though the last piece of state did now cost me some uneasiness, for my legs were constantly asleep. The attitude of sitting upright had become quite strange to me. I used to pass the greater part of the day in the shed that served as a warehouse, and a shop for the barter trade, and I was in constant communication with the Ottoes, who came continually across the frozen Missouri to exchange their furs for the manufactured goods brought by the whites. old Wo-nes-hee presented himself every morning, and moreover got up in a style of deep mourning for a son, who had been killed many years before. He had coloured his face quite black, and pasted his hair together with ashes and water, and in this melancholy state he used to present himself before me, and weep bitterly. If I did not then console him with a glass of brandy, he would break into a loud howl, and continue 
this noise, to the great amusement of my white friends, until I had manifested my sympathy in the manner above mentioned. I cannot say but that I was very unwilling to afford him this comfort; for in the first place I was quite without money, and had to take the smallest trifle upon credit, without knowing when or how I should be able to pay for it, and secondly, I had a horror of affording old Wo-nes-hee any assistance in the gratification of this destructive propensity.

"As my old companions came daily to visit me, I used to return their visits in their wigwams, and invariably met with a cordial reception, and found a dish of meat in readiness for me; I used to accompany them too on their hunts, and often found much food for reflection in the conversation of these poor savages.

"In the course of a week I had the satisfaction of presenting myself in civilised costume; and I was indebted to the skill of a woman for a magnificent coat, which she manufactured for me out of a green striped blanket, and in which I flatter myself I created no small sensation in the Indian village.

"When I had entirely recovered my health, and got my weapons into good order, I laid in a stock of ammunition, took leave of my white friends, and returned to the Ottoes. I was induced to do so from having heard that twelve miles northward from Bethlehem (the settlement where I had been staying), there was a village of Omaha Indians, and not far from them a trading post of the St. Louis Fur Company, an Indian Agency, and a Presbyterian mission, which I wished to visit, but not without having first taken time to become well acquainted with the Ottoes.

- "This tribe, originally called $O$-ta-ta-toes, now numbers 
only about 600 souls; but the Missouris, their former neighbours, have been for years associated with them, a union which may have been brought about by the resemblance of their languages, but especially by the decline of their numbers, for the Missouris have dwindled to 400 .

"Each tribe is subject to the authority of its own chief; but they occupy a village in common, are generally seen together in their hunting and war parties, and perform together their wild picturesque dances, in the valley at the mouth of the Nebraska. The men are large and vigorous in their forms, and among the women and girls are to be seen some really pretty faces. You will suppose from what I have said of the friendly disposition of these savages towards me that I was able to go about very freely among them, and every wigwam was opened to me with ready good will; but I had to be on my guard against the effects of drunkenness. As it was easy for them to cross the frozen Missouri, and procure brandy from the whites, some of them were always in such a merry humour, that they were inclined to play with knifes and tomahawks as if they had been feather balls, and I had to be sharply on the alert to dodge these murderous instruments as they came whistling by me.

"I took care, however, not to give offence by manifesting any anger or annoyance, but laughed at these facetious demonstrations, and never got into any dispute with the savages.

"On the second evening of my stay in their village, my equanimity was, I must own, put to so severe a trial, that had I seen any possibility of making my escape privately, I should certainly have done so, for I, 
thought the scene rather too much for a joke, though nevertheless remarkable enough to attract my curiosity. This was on the occasion of a "horse dance," which was performed with an impassioned fervour, solemnity and effect, that can only be seen among Indians. Had the performers been all sober, it would have been a real enjoyment.

"Imagine a crowd of finely-formed men, with their naked bodies and faces painted in what is considered the most terrific manner, their limbs covered with fantastic ornaments, their fluttering scalp locks adorned with feathers, and armed with all the weapons they could muster, dancing, leaping, and yelling round an enormous fire, whose flame blazed up far into the night sky, whilst the dancers, contorting their symmetrical limbs into the most extraordinary attitudes, brandished their weapons furiously as if against some invisible foe. You will not wonder that my attention was strongly attracted, and I sat down at the beginning of the dance by a small fire in the snow, to look on at the mad revel.

"The songs and yells were accompanied by the beating: of three drums, and some pipes, and as the drummers became excited by the remembrance of their warlike deeds, they stamped furiously on the frozen ground, and the perspiration streamed over their painted cheeks, while their weapons flashed in the red light of the fire. A gigantic warrior in dancing past me, suddenly made a thrust with his lance at my breast, though probably without any intention of hurting me, but I involuntarily started back; this retrograde movement of mine was followed by a general scornful laugh from the whole assembly, which was joined in, to my great vexation, by the women and children, who were looking on at the 
dance from a modest distance. I had betrayed a weakness that I must endeavour, I thought, to make good again, and I took care not to blink when soon afterwards a tomahawk was flung, and came whistling past me. After this, weapons of various kinds came flying in this unpleasant manner, much nearer than I liked, and I began to fear that the unsteady hand of some drunken fellow might bring a sharp war hatchet into awkward proximity with my skull.

"I sat still, and smoked my pipe with apparent composure, but I was considering in what way I could manage to make my exit from the performance. To walk away openly would have certainly been to get myself branded as a coward, yet it did not seem advisable to stay. That the people were not ill-disposed towards me was evident, even by their behaviour in the dance ; but their friendly feeling was but a poor security, since a weapon from the hand of a drunkard might put an end to my life in a moment. In such a case the worthy Ottoes would, I do not doubt, have regretted the accident, just as we may do, if at one of our dances an awkward fellow spills a glass of wine on a lady's new dress; but it would have been a poor way to lose my life.

"After a little cogitation I hit upon a plan that enabled me to avoid the present danger, and at the same time decidedly raised me in the esteem of the Indians, though my civilised friends may choose to consider it undignified. I threw off my coat, stripped my arms bare, daubed them and my face with red paint, which was offered to me from all sides, and then taking my long hunting knife in my left hand, and my revolver in my right, leaped into the circle, and began to exercise 
my feet and my lungs in as complete an imitation of the Indian style as I could get up. The redoubling of the yells and howls indicated the satisfaction afforded by my behaviour; and I exerted myself not to fall behind my associates. It was hard work, but my performance was applauded, and I had escaped from my former very unpleasant position, besides warming myself with the exercise.

"As I had no very strong wish for an invitation to another Indian ball, I resolved to set off sooner than I had otherwise intended, on my visit to the station of the Fur Company; but my intercourse with the Ottoes was by no means at an end; for as long as I remained, my old companions used to come over and see me, and take occasion to mention the subject of tobacco and red paint. One particularly ceremonious visit I received from two men of distinction in the tribe, denominated $W a-r u c k$-scha-mo-nee and $K i$-ka-poo, who were returning loaded with presents from Washington, where they had had an interview with the Great-Grandfather.

"Wa-hi-ta-mo-nee, my proposed father-in-law, was also in the suite of these chiefs, and reminded me in a friendly manner that the Spring would be the time for me to begin hunting the buffalo, and stealing horses, letting fall a hint also, that if I could make it convenient to steal them from the Siouxes, the hereditary enemies of the Ottoes, it would be the more agreeable, and that a robbery of that nation was the more desirable, as it would give me an opportunity of taking one or two scalps. He did not mention the danger that might happen to arise to my own locks during the operation.

"On a bright, but dreadfully cold morning, I set off in company with Louis Farfar, and some young men of 


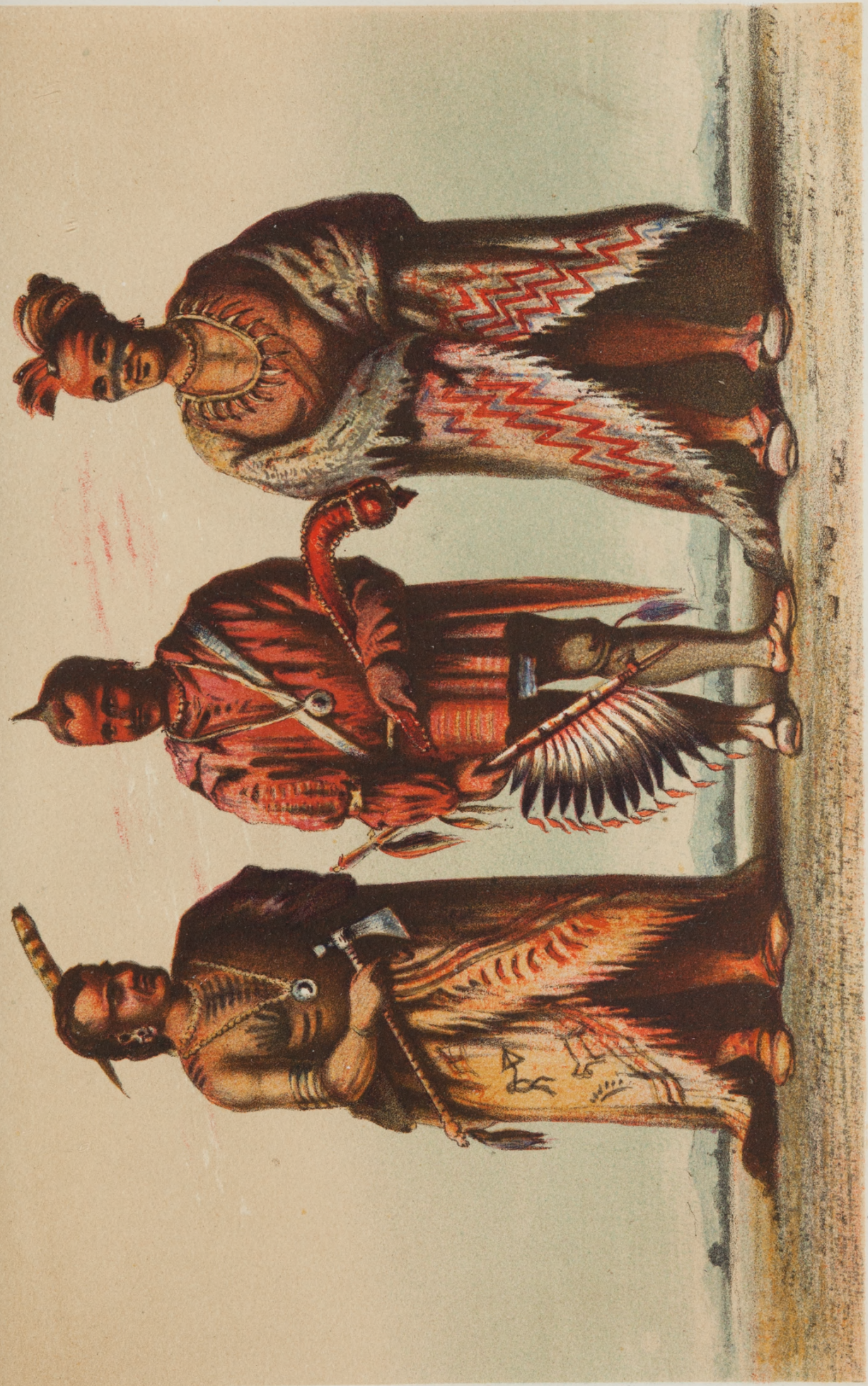



the tribe, and turning my back on the Otto village, walked stoutly forward up the Missouri.

"The snow was covered with a hard crust, so that it was not difficult to walk upon it; and as we proceeded on our way the woods became lighter, and when we got as far as where the Papillon or Butterfly Creek falls into the Missouri, we found ourselves on the edge of a broad prairie, on the opposite side of which we could see the Mission and the Agency, with their buildings and enclosures pleasantly gleaming in the sunshine. We hastened on towards them without stopping, and leaving the Mission on a hill to the left, just as the sun was shedding his last rays on the hills, I found myself before the door of Mr. Sarpy, the chief of the Fur Trading Post, who received me with the warm hospitality characteristic of the Far West.

" "How do you do, sir? Cold weather we have got; throw those thin shoes of yours into the corner, and put on a pair of mine: here Joe! Bill ! throw some logs on the fire ; make my house your home, sir.' These, and words to the same effect, were poured out upon me by Mr. Sarpy with such cordiality on my entrance, that I felt quite as if I had met a friend, especially as he took a short pipe that he was smoking out of his mouth, and handed it to me to take a few whiffs in the Indian fashion, and after this sign of welcome placed it again between his teeth. The apartment was a spacious one, quite a drawing-room, and furnished with a writing table, an old sofa, a rocking chair, and some settees; but the number of seats was very disproportionate to the number of guests by whom it was thronged. This did not, however, disturb the visitors in the least, for they squatted very comfortably on the floor, and 
enjoyed the general warmth diffused from the colossal fire-place. I made my way with Mr. Sarpy through the crowd of Indians, half-breeds, and whites, and took my place by his side opposite the huge pile of fire, to pass the evening in pleasant gossip.

"This Mr. Sarpy was the most complete specimen of the backwoodsman that I had seen. He is one of the principal officers of the Fur Company, has been actively engaged in the trade for more than thirty years, and has made a considerable fortune. He is married to an Indian woman, but has no children, so that his money will all go to those of his brother; but notwithstanding this, he has no desire to escape from the hardships and inconveniences of a mode of life that has become a second nature to him. I once asked him why he did not rest upon his laurels or his money-bags, and go and enjoy his wealth in some of the capitals of Europe.

"'It's no use talking,' was his reply; 'I've been thinking about that this fourteen years, and every year when I went to St. Louis I had half a mind not to come back again; but I could never stand it more than four weeks. The first week was jolly enough, but I got tired of the jollifications by the second, and the third I began to long to go back to the Far West, so I bought myself some clothes and boots, and got home again to my old Necoma, who was out of her wits with joy to see me back. That's been the way for years, so at last I have given up the notion of ever being anything else than what I am, and in fact I don't know that I should be willing to change with any man in the world.'

"So stand affairs with Mr. Sarpy; his log houses are palaces for him, and the wide West his world; the 
Indians afford him amusement, and his journeys to the various prairies occupation, and the occasional dangers and privations to which he is subjected, serve as condiments to his life, and keep him in health and vigour.

"I do not suppose that for fifteen years there has been the smallest change in his appearance, except perhaps that they have left a snow flake or two upon his head. By the time I had wished him good night, and he was leaving me to climb up into his rather more convenient sleeping apartment, he was acquainted with most of the history of my life, not excepting the circumstance that at the present moment I had hardly anything in the world that I could call my own except my weapons. My clothes I could not call my own, for they were had on credit. Mr. Sarpy, however, appeared to think this a matter of very trivial moment, and called out from the door, 'Your first business while you stay with me must be to get up your health and strength again, you can think afterwards about earning money. You will find plenty of opportunity for that here, but very little for spending it. Good night for the present, lie down there in the corner; there are plenty of buffalo, otter and beaver skins, make yourself comfortable and sleep as well as you can.' Soft buffalo, shaggy bear skins, and a room filled with warmth from a large fire on the hearth, promised no uncomfortable place of repose; a much better bed I thought it than the kind of wooden scaffold I had slept on at Mr. Marten's. The blaze from the large logs lit up the room to its farthest corner, and displayed the wild forms which half or wholly wrapped in blankets lay on the ground, near each other, some asleep, others singing or conversing; until at last sleep overpowered all eyelids, and no other sound 
was to be heard than the deep breathing, the crackling of the fire, and the wind roaring in the chimney, only occasionally there was a moment's interruption to the silence, when a dreaming warrior murmured some wild words, or a naked glossy figure arose, went softly to the chimney, raked the dying fire together, and supplied it with fresh fuel.

"In this way I passed my first and all succeeding nights as long as I remained with Mr. Sarpy, and the only difference was, that with the exception of the whites, the members of the party were continually changing. I seemed at first to have nothing to do but to make new acquaintances perpetually. People went and came, new faces and new forms crowded $\mathrm{Mr}$. Sarpy's hall, which resembled a well filled stage, and all the more because the tremendous severity of the winter mostly kept both guests and host within doors. I had an excellent opportunity here of keeping myself in practice in drawing, and I was the more inclined to do so, as I contemplated carrying away with me to my home, something more than mere recollections of what I had seen. But as you would hardly wish, I imagine, that I should give you an exact account of every day I passed at Mr. Sarpy's establishment, I will just mention a few of the objects and incidents that occur to me.

"As I have before stated, we held intercourse chiefly with the tribe of Omaha Indians, a race always remarkable for good feeling and friendliness to the whites. Their village lies on a high bank of the Papillon Creek, about six miles from the Missouri, and its site is very judiciously chosen, so that the inhabitants, though not now more than 1500 , are well able to defend themselves 
against a greatly superior force. The chief Onga-tonga (the Great Stag) has great authority over them, though perhaps hardly as much as his father, who died at the age of eighty, deeply lamented not only by his own tribe, but also by the white population at the other side of the Missouri. The grave of this distinguished warrior is on a hill overlooking the Missouri for a great distance; there lies Great Stag the First, with his war horse and his weapons, the spot being marked by a slab and some stones, to remind the passer by of the departed. But he needs no such memorial, for his name will live at Council Bluffs when the plough shall have passed over his grave, and busy white men have scattered seed in the furrows. An anecdote from the life of this noble savage will serve to illustrate his character.

"The stations of the St. Louis Fur Company in the West, although very remote from each other, keep up a kind of intercourse, and the chief officers at Forts employ for this purpose Indian messengers, who, furnished with some provisions and weapons, will travel for hundreds of miles alone through the wilderness, to carry letters and. messages, and after a short rest are ready to return. In order to leave a less remarkable track behind them, and the better to conceal themselves when in the neighbourhood of hostile Indians, these messengers usually travel on foot, and yet quicker than a horse would do through these pathless wilds. A good many years ago, while the first Onga-tonga was still alive, and though old, always ready to accompany the youngest warriors in their expeditions, a Canadian hunter was sent with letters and despatches to the commander of the Station near the Ponka Indians, at 
the 'Running Water.' He was a stout young fellow, and choosing for the above-mentioned reasons to traverse on foot the part of his journey that lay for 200 miles along the Missouri, set off briskly enough, and pursued his way for a week without meeting with any hindrance. But at the end of that time he one morning awoke so ill that he felt it was impossible for him to proceed any further. He could not, indeed, stir from the spot, and he lay in a most helpless condition for several days, when he perceived that he was attacked by small-pox, the most dreadful scourge of these western regions, and the unfortunate creature resigned himself to his fate, and felt thankful that at least he lay near a spring, from which he could cool his fever-parched mouth.

"By an extraordinary chance, however, Onga-tonga with six of his warriors passed by the spot as he lay, and the old chief who recognised the pestilential malady at the first glance, after a little hesitation, took a resolution that would have done honour to many a pious missionary. Having learned that three of his people had had the small-pox, and might therefore be considered safe from the infection, but that three others, as well as himself, were liable to it, he desired the latter to avoid the sick man, and go home by another path, whilst he, and the three who were in no danger, should convey the sufferer to his home. He then had a sort of litter made of woven boughs, on which he and his comrades placed him, and so proceeded, bearing the dangerous burden on their shoulders towards Belle Vue. They reached it after an indescribably toilsome journey of fourteen days' duration, and fortunately were well rewarded for their humanity. Their patient, too, had to 
their great satisfaction so far recovered on the way, that he was soon able to resume his employment, retaining only the ineffaceable marks of the terrible malady. By such actions as these the grey-haired warrior had won the general esteem of the whites, as well as of his own people, and if you make any inquiry about him at Council Bluffs, you will hear from all sides that he was as soft-hearted as a child to the sufferings of his fellow men, though his war cry was terrible to the ear of his enemies, from whom, it is added, he took many a scalp, now mouldering beside him in his grave. When this chief, on one occasion, went to Washington, his portrait was taken by order of the Government. It is said to be a striking likeness, and it now hangs, with the portraits of other Indian warriors, in the hall of the Ethnological Collection, in the Patent Office, where it may still be seen.

"Onga-tonga the younger is also a renowned chief, but does not appear to possess the noble qualities of his father. He is hospitable to strangers, however, and since I had formed a kind of friendship with him, I had often an opportunity of witnessing the 'medicine dances' of the Omahas.

"The warriors of the tribe are divided into two companies, differing in costume and manners; and the young people are allowed to join one or the other, as they are induced to do, by dreams, or conjurations, or other 'medicine.' One of these divisions wears the hair long, and decorated with owl's and vulture's feathers, and a tuft of coloured horse hair. The other shaves the head, and only leaves the scalp lock, to which is fastened the bright red tail of the Virginian deer, that rising above the head like a cock's comb, seems to bid defiance 
to an enemy, by offering itself as a convenient hold to facilitate the process of scalping. In the painting of their faces and bodies there seems to be no established fashion, every one following his own taste. In smoking there is a difference observable, one merely passing the pipe round, the other holding the bowl and its glimmering contents carefully in their hands, and not allowing the person to whom the pipe is presented to touch it. All Indian dances consist in stamping with the feet in time to the drum, and either shifting from one foot to another on the same spot, or moving round in a circle, and imitating the motion of animals; from which the dances receive their various appellations of Buffalo, Bear, Horse, Beaver, and Dog Dances.

"The most interesting exhibition of this kind that I ever saw, was from a troop of long-haired Omahas, who visited us at Belle Vue. Their costume was so extraordinary, and consisted of such glaring colours, and such a quantity of ornaments, that it was not easy to distinguish the human form beneath it. The head-dress was always the same, namely: a great plume of feathers ; but there were scarcely two lines of paint alike, in the whole party, consisting of thirty men. Their soft leather garments were embroidered with beads and coloured porcupine quills; and there were such masses of leathern fringes, scalp locks, horse tails, skins of birds, and reptiles, and quadrupeds, fastened to the arms and leggings; such double and triple chains of beads, shells, tiger's teeth and bear's claws, round the tattooed necks, and such quantities of brass rings round the arms, that the eye was fairly bewildered.

"This wild troop, thus superbly got up, placed themselves in a semi-circle, and every one took in his right 
hand a kind of rattle, consisting of an elegantly-cut stick, with a number of claws fastened to it, with which they accompanied the beating of the drum by four elderly warriors, the wild songs of the dancers, and the shrill piping upon hollow swans' bones, which completed the dreadful concert. Some old warriors, painted black, walked up and down behind the performers, and encouraged them with loud shouts to renewed exertions, boasting at the same time of the valour of the tribe, and recommending the spectators to make them plenty of presents, a recommendation which the whites and half-breeds who were there, did not fail to attend to, every one contributing according to his means.

"Flour, blankets, paint, tobacco, nay, even horses were bestowed upon the dancers, whose spirits were raised by this liberality to the wildest state of ebullition, until at last the Medicine man declared the dance concluded, and the corps de ballet dispersed in different directions, to strut about in their finery and get admired. Indians are astonishingly vain, and I really believe spend more time and trouble in their decoration, than the most complete dandies of the civilised world, very few of whom, probably, contemplate their images in the glass with half the anxiety the Indian bestows on his little mirror, the size of your hand, when he is beautifying his visage with its manifold streaks of paint.

"I never see a European exquisite, however, without being reminded of a Red-skin, though the uncivilised beau has the advantage of the two, in inspiring respect, since he displays, in addition to his delicate paint, the claws of the bears he has killed, and along with the more innocent glittering rattletraps in which he takes pride, the scalps of his slaughtered enemies. This hor- 
rible practice of scalping, which, we may remember, is seldom possible unless the victim has been previously rendered senseless, appears to have existed among these nations from the remotest antiquity, and will, it is to be feared, continue as long as there are any wild Indians in the woods and steppes of America; even when they have been half civilised they retain a strong inclination to see the locks of an enemy dangling at their girdle, which is regarded as an infallible evidence of courage, not altogether without reason, for it certainly requires more to struggle hand to hand with a foe for this bloody trophy, than to send a bullet into his breast from a distance. The possession of a scalp stamps a young man at once as a warrior, and procures him esteem and influence among his comrades. An Indian seldom mentions the defeat of an enemy unless he has taken his scalp, as he would be supposed to be lying; no very improbable occurrence it may be observed, for as Indians are most determined boasters, they are frequently led into lying almost unawares."

The speaker was here interrupted by an exclamation from one of the party, on the cruel way in which the Mexican boy Vincente was using his horse. He was endeavouring to force it to the pursuit of a herd of flying antelopes, and when he found it did not succeed in bringing him near them, he was beating it unmercifully. "That boy does eredit to his Indian teachers," said the doctor; but while we were all watching his proceedings, suddenly horse, and rider, and antelopes all vanished together from before our eyes in the naked plain. He had been far in advance of us, and his disappearance was at first inexplicable, as the wide plain showed no kind of elevation or depression that might 
have served to conceal the wild chase from us, but the riddle was solved when we had proceeded a little further by the discovery of a broad chasm or ravine, stretching from north to south, and showing by its broken banks and the lesser chasms at the sides, how the heavy rains not only wear away the edges of the plateau, but break through the thick stratum of sandstone, so as to form new valleys and act with destructive force in all directions.

The expedition halted at Encampment Creek, and made its way down to where some shady cotton trees offered a good place to draw up the waggons, and allow the cattle some hours' rest. The human part of the company was provided with a tolerable sufficiency of water for the day, but the want of it was much felt among the poor beasts, and even a scanty drink would have been a great benefit to them. Some of the people were therefore commissioned to search the dusty bed of the brook in all directions for water; but they had scarcely got down to it before they met Vincente, who had ridden a long way down the valley, by which his sudden disappearance was explained. He brought the unwelcome intelligence that, as far as he had seen of Encampment Creek, there were no signs of water. Thereupon the attempt was made to obtain some by digging in the sand, but in vain, and the poor animals had to content themselves with the fresh grass that shot up scantily in this wild valley, and with the hope of a better meal at night. Just as we were about to start, one of the soldiers of the escort, who had been rambling about, brought news of having discovered a small spring in a rocky chasm; and it really appeared on examination that he had not deceived himself, for some clear drops were trickling out of the veins of an 
immense bed of sandstone, which, at the distance of fifty paces, where the hardness of the stone had prevented the water from sinking in, had formed small puddles, though further on it was entirely lost in the sand. The extremely small quantity of the water, how. ever, and the narrow inconvenient chasm in which it was to be obtained, would have occasioned too much loss of time in watering the cattle, and we therefore left Encampment Creek and journeyed on again over the high arid plain. Two horsemen only had remained behind, and were seeking along the edge of the valley for the point where the best view of it could be obtained. The geologist of the expedition had requested me as draughtsman to give him a sketch of Encampment Creek, and was indicating the features that he wished to have particularly noted, such as the horizontal stratum of grey sandstone, which covers the elevated plain only a few feet below the surface, and which could be seen all along the valley, cropping out at the broken and indented banks, and always at the same height; the winding bed of the stream itself, and the perfect level of the Llano above. This spot was to be examined with more attention, because it was the only stream, or rather bed of a stream, which the expedition had touched on the Llano Estacado, and especially as on these banks the geological formation was laid bare to a depth of 180 feet.

As soon as we had completed our work, we hastened after our companions, and when we turned after going a short distance to look at Encampment Creek again, it had entirely disappeared, and we saw nothing but the dreary, monotonous plain. Towards sunset, a wide unbroken level still stretched out before us, and 
we saw that on this day we must make up our minds to a late halt. Small herds of antelopes accompanied our cavalcade, leaping along at a short distance, and perpetually tempting our sportsmen to a vain pursuit, frequently leading them far away, and then flying back again, apparently to amuse themselves with the unwonted spectacle of horsemen and waggons. The sunbeams fell more and more slanting on the plain, until at length even the little hillocks of the prairie dog villages cast short shadows, which gradually lengthened, and then blended into one; the dry wind that had blown over the open space during the day, died away, and allowed the faintest sounds from the remote distance to reach our ears, and the small voices of the thousands of tiny dwellers underground mingled into a faint murmur. The wearied cattle were getting very much annoyed by the dust which had been carried away by the wind during the day, but now rose in clouds and hung round them, so as to oppress their breathing; and we all looked longingly towards the west, but nothing as yet indicated the termination of the Llano Estacado, and the end of this exhausting day's march; the sun sank lower and at length lay like a fiery ball upon the dreary plain, not radiant as in the morning, but of a dark glowing red; even he seemed tired with his day's journey, and accordingly soon betook himself to rest, carrying away the twilight with him, and leaving our caravan in darkness.

If in the day time, the prairie often reminds you of the ocean, it requires at night still less imagination to fancy yourself on the wide sea shore, or on some small island in the watery waste; but the darkness did not last long, for the stars soon appeared sparkling in the 
dark blue sky, and the high curved arch of the Milky Way shed its mild light upon us, as the long dark procession moved slowly on its way like a black shadow across the plain, while a silvery light in the east announced the rising of the moon. Then the light turned of a reddish yellow colour, like that of a distant conflagration, the whole atmosphere became filled with a brightness that dimmed the splendour of the stars, and the large disk of the moon had just rolled up above the horizon, when "Halt!" was suddenly heard from the advanced guard of our procession. The command was instantly obeyed, and an inquiry ran along the line after the cause, though the mules neighing and shaking themselves in their dusty harness seemed to say that their instinct had already informed them of it, namely, that the end of the plateau was gained, and water was near.

We hastened on to find the best way to get down to the valley, which lay like a black abyss before us, for the moon was not yet high enough for her light to reach down into it; and as some Mexicans who had been sent forward to find out the best camping place in the Rocky Dell Creek, assisted us by lighting fires and firing shots, the whole expedition effected the descent over the loose stones in safety, and were soon busily engaged in pitching the camp, glancing up occasionally towards the edge of the plateau, to watch when the moon, rising to them a second time in the same evening, but now from amongst black masses of rock, should afford them light enough to see what they were doing.

When we left the tents on the following morning, we found we were on a rough stony tract at the foot of the high plain, and although the barren soil promised but scanty nourishment to our cattle, we determined to 
rest for one day, and the individual members of the party thereby gained an opportunity of exploring the environs. Rocky Dell Creek, on whose sandy banks it was no easy matter to fix the tents, flows over a bed of red and grey sandstone and pebbles; but at the time of our arrival, there was no continuous stream of water at all, though the deep basins, hollowed out by the rushing torrents that pour down into it at certain seasons, were full to the brim both of water and fish of many species, and offered a cool and welcome draught. Huge masses of rock lay piled in a picturesque manner on one another, forming grottoes and caverns, some large enough to have afforded a convenient place of refuge for twenty men in case of bad weather. The clefts in these caverns seemed, however, to be a favourable place of residence for the diamond rattlesnake, for our men killed several of an extraordinary size as they rambled about.

The overhanging rocks were richly adorned with small swallows' nests, which adhered to each other, and hung in complete garlands over them, and an attempt was made to detach some of them, from the rock, and add them to the naturalist's collection, but carefully as we went to work, we did not succeed in a single instance, for the lightest touch disturbed their delicate structure. They are made of a kind of loam, but fixed so firmly to the rocky wall, that the last fragments could only be detached with a knife. One of the largest of these caverns attracted particular attention on account of some paintings and engravings apparently made in the soft stone with pieces of iron or the points of arrows, that appeared on the walls and roof. Some of these curious representations doubtless owed their origin to the sportive caprice of Indians or 
Mexicans, but the majority of them bore a character that could only be explained by reference to the superstitions of the Pueblo-Indians.* The most striking was the fantastic sketch of a large animal, half dragon, half rattlesnake, with two human feet. This monster which took up half the length of the cave, was evidently a sort of divinity of the descendants of the Aztecs, and it was explained to us in the following manner by two Pueblo-Indians who came in. The power over seas, lakes, rivers, and rain, has been assigned to a great rattlesnake, which is as thick as many men put together, and much longer than all the snakes in the world; it moves in vast curves, and is destructive to wicked men. It rules over all water, and the Pueblo-Indians pray to it for rain, and reverence its powers. The representations of two misshapen red-haired men, were rather boldly declared by the same Indians to be meant for Montezuma, to whose reappearance the inhabitants of the Pueblos, although they call themselves Christians, still secretly look forward.

The sun, as the symbol of supreme power, was not wanting among these pictures, but otherwise they consisted merely of childish attempts to represent animals of the country, Indians and their modes of warfare.

On the days of rest, our camp would have presented to a visitor, who might happen to enter it, a picture very different from its ordinary lively bustle. No other than trivial and necessary tasks were undertaken, and in these every one suited his own convenience, and paid

* The natives of the country who live in towns or regular villages, are called by the Americans, Pueblo-Indians, from the Spanish word Pueblo, - town, or village; as we speak of those of the steppes as Prairie-Indians. 
as much attention to his comfort as possible. The greater part of the company might be seen seated on their blankets, mending their clothes or their shoes, or reading in old thumbed-out books, or playing at cards, and here and there, a bearded fellow was lying on the edge of the water, and in a leisurely manner washing his linen, which operation is on these journeys somewhat superficially performed, no very fastidious amount of nicety being required. From the field-smithy, indeed, are heard the strokes of the hammer, indicating hands more industriously employed in replacing the lost shoes of the mules ; but the astronomer is falling asleep over his angle measurements and tables of logarithms, and near him is one supposed to be making an entry in his journal, but the pencil has fallen from his hand, and his condition seems to imply the infectious character of laziness. The botanist, however, had early in the morning carefully laid out a whole pile of damp papers to dry on the grass, and now, sitting in the shadow of his tent, he is helping the naturalist to skin a wolf, and taking the opportunity to give him a lecture on anatomy.

"I am so glad we have made a halt to-day," cries the doctor, in a state of high satisfaction; "my stock of dried paper was almost used up, and now I shall be able to prepare in a few hours what will last me a long time." How short-sighted are mortals! The old gentleman had scarcely the words out of his mouth, before a sudden and violent gust of wind arose, shook some of the tents furiously, overthrew others, whirled up a cloud of sand and dust into the air, and swept off, in a moment, the multitude of sheets of blotting paper, that had been spread out to dry. "Oh my beautiful paper!" cried the horrified botanist; and letting fall 
the bleeding form of the deceased wolf on the knees of his friend, he rushed after the sheets that were whirling by hundreds in the air. Away went the paper, and away went the doctor after it; along the glen, up the craggy walls of Rocky Dell Creek, and out over the wide plain, the doctor's friends of course enjoying his misfortune, and shouting with laughter. Fortunately, the squall died away again before the ardour of the chase had carried him too far, and the crumpled sheets came fluttering down to earth again, the doctor rushing panting after the fugitives, of which, with a little help from other hands, he succeeded in collecting the greater part. He returned at last to the tent quite tired out, and when requested by his friend to lend a hand in the preparation of the wolf's skin, answered somewhat testily, that for three days at least he should have enough to do to smoothe his crumpled paper, and forthwith disappeared behind his canvass curtain. "You owe me some compensation though," the other called after him, "for having daubed my clothes with the wolf's blood;" but he managed to finish the work by himself, and then went out to take part in the general shooting practice, that formed the occupation of the party for the rest of the day.

I mention these little daily occurrences of our wandering life, as illustrative of the twofold character of the Expedition. Having to open a way through almost unknown regions, where we might have to defend ourselves from hostile encounters, it had a dash of the military character; but the inquiry into the geological formation of the country, and its animal and vegetable life, and the determination of distances, \&c., by astronomical observation, formed, as will be seen, our principal business. 
CHAP. XIV.

WESTERN BOUNDARY OF TEXAS. - CERRO DE TUCUMARI.-THE ROBBERS OF NEW MEXICO. - TUCUMARI CREEK. - PYRAMID ROCK.

Having crossed the Rocky Dell Creek, we were now beyond the western boundary of Texas, and had traversed the entire extent of this territory from the Antelope Hills to the above-mentioned river, a distance of a hundred and eighty miles.

From the foot of the great table-land we proceeded on our way. The river Canadian turned towards the north, our road more towards the south, so that the space between continued to increase; and we had on the north the view of a rolling plain, and on the south the broken ridge of the Llano Estacado. The furrowed, uneven ground would not allow us to keep so far south as to be able to get fuel from the woody dells. The evenings were cold, and we all looked longingly over towards the stunted cedars, and covered ourselves more closely with our wrappers. The cool evening air was the more trying, from the heat of the day increasing so much, that at noon it was even offensive; but to make us some amends, the mosquitoes had suddenly disappeared, and man and beast were thereby delivered from one great plague. In various ways autumn was making known its coming; large flocks of birds from the far north were seen flying towards the south, making the 
little brooks and their banks all busy with life, and showing so little fear of the hunters, that they were shot in great numbers. Sporting of all kinds became more productive; and it was often easy, by means of the uneven ground, to get quite close up to a brood of antelopes, and select a noble buck from their midst without being seen. As game increased, so did the love of sporting; and solitary horsemen were to be seen in all directions, who had separated from the main body to try their fortunes in the chase. Some were successful, some not; but on some days, even the waggoners of the expedition had plenty of game for dinner.

From Rocky Dell to Fossil Creek, a distance of fortyfive miles, the direction of the road was determined by the table-land, and no variation in the scenery was perceptible; only now and then we crossed a brook of running water, which gave indications of springs in the dark clefts, though many of them might merely have been rain-water courses running down to the Canadian. The road here bore marks of some not inconsiderable traffic, carried on at certain seasons of the year, probably for centuries past, between the Indians and New Mexico. In very ancient times civilisation must have made its way upwards from the Gulf of Mexico to the Rio Grande, and seldom been absent from this valley. But the spirit of enterprise of the old Spaniards died out everywhere amongst their descendants, who never ventured to wander far either east or west from the settlements made by their ancestors. Even if they had not feared the attacks of the natives, whom they were hardly in a position to face with advantage, the flat desolate region around would probably have offered little to invite them out of their usual course. They lived 
where they had been born, and contented themselves with occasionally forming little caravans for journeys over the prairie to visit the Indian villages and carry on a little trade with them. On the other side, however, where Anglo-Saxon civilisation took root, nearly a century later, the progress was rapid westwards, and population and enterprise increased as if by magic. Victoriously rolled the tide of progress far out along the Mississippi and Missouri, checked neither by the apparently impenetrable forests, nor by arid plains, or savage natives. But sweeping in one mighty wave from the shores of the Atlantic, over the American continent, to meet at last, at the Rocky Mountains, with another wave from the Pacific Ocean; with which it united, to overflow, and shortly absorb, the entire population of New Mexico. These kind of thoughts occurred to many of us as, wandering along this road, we came upon frequent traces of ancient intercourse; and certainly no one could withhold the most hearty wellearned admiration from the brave old Spaniards who left these inscriptions and monuments, more than two hundred years ago, in these regions west of the Rocky Mountains, which have been but within these few years discovered and described by the Americans.

About twenty miles from the end of the table-land and Fossil Creek, we saw a distant mountain rising like a faint blue cloud along the plain and noticed it the sooner, from being accustomed, as we were, to see the horizon line of plain and sky mingling in the west. As, mile by mile, our expedition made its way towards this point, we began to perceive, more and more distinctly, the outlines of an insulated table-rock, which rose like a gigantic cathedral, from the level surface. But 
two days' journey still lay between us and this point. If it were really the Cerro de Tucumari, described by an earlier traveller, our road must pass close to it; but before we could reach it we had to traverse a great extent of hard unfruitful soil, which yielded very poor provender for our beasts. The young men still kept up their spirits, however, and thought with delight of the time which they should now soon be spending in the settlements of New Mexico. Whenever a few of them were seen collected together preceding the train of waggons, and talking with animation, you might be sure they were discussing their stay in Albuquerque.

"Well, we shall be soon in the promised land now," began Mr. Garner, an American, who was riding in the midst of a group of comrades, letting his mule take its own course; "in the land of fandangos and bowie knives, of lassos and red pepper, of Quien Sabes and señoritas. Many a pleasant day have I passed there already; for I too, like Dr. Bigelow, belonged to the Boundary-surveying Commission; I hope, though, we may not have to witness such scenes of horror on this journey as on that." At these words he turned to the doctor. "Do you remember," cried he, "at Socorro your driving a troop of murderers with an unloaded musket out of your room, into which a dying man had been brought, a victim of the lawless barbarians?" "Ay, well do I remember those times," answered the doctor; "terrible they were, and it does seem incredible that such things as those you allude to could have happened in the nineteenth century." "In order," continued Mr. Garner, turning to the rest of us, "to make you understand how these things happened, I must go a good way back. When the Boundary Com- 
mission landed on the shores of Texas in 1850, about fifty waggoners and other workmen had to be engaged for it. The quartermaster, on whom the difficult task of engaging them devolved, found no great choice, and was obliged to take the men pretty much as they came. It is not strange, therefore, that a collection of the most worthless and depraved fellows were thus taken into the service of our Government; and on our arrival at El Paso and San Eleazario, it was found necessary to dismiss some of the worst subjects. Some companies of emigrants making their way to California, as well as several trading caravans, had done the same thing at this very same place; so that some of the very scum of the human race were collected together in these little settlements, with no means of honest livelihood, even if any of them had been inclined to reform their way of life, and no money; for such of them as had had any to begin with, had soon lost every cent in gambling.

"The peaceable inhabitants of Socorro, a place where caravans usually halt for a short time, were especial sufferers from this circumstance; their lives were no longer safe, not only out of doors, but even by their own hearths; for the audacious robbers made their way everywhere, leaving too often a dwelling stained with the blood of its unoffending inmates. Many of the Mexicans, conscious of their impotence to withstand the brute force of their enemies, packed up their goods, left their homes, and migrated to distant settlements. This was the position of affairs when our Commission arrived, but the appearance of an armed, well-disciplined force, alarmed the company of gamblers, horsestealers, and murderers, and made them more cau- 
tious in their proceedings. Hardly, however, were the various surveying parties sent off in different directions, when the former atrocities recommenced. Houses were mercilessly broken open, in order to satisfy the most disgraceful and criminal passions, and every new deed of violence increased the temerity of this terrible gang, by convincing them of their power and impunity. After several murders had been committed, the welldisposed inhabitants of Socorro associated themselves for the purpose of putting an end to these outrages, and requested assistance from the military post of San Eleazario ; but the assistance was refused by the commanding officer, on the ground that it should have been first asked from the civil authorities, and so things went on in the old way, and it seemed likely that the little town would be entirely depopulated, as all the inhabitants who could leave it were hastening to do so. One evening a ball was to be given, a very frequent diversion in all Mexican towns. These fandangos, as they are called, are open to every one, and, as may be supposed, the band of robbers above mentioned did not fail to enliven the meeting with their company. Their brutal behaviour soon attracted attention; pistols were fired over the heads of the women, but when they fled in terror to the door, they found it blockaded by some of the ruffians, who compelled them to remain. The excitement in the confined space then became greater, and at last bowie knives were drawn and used. A Mr. Clarke, the assistant of our quarter-master, who happened to be present, was the first victim, four of the villains attacking him at once with their bowie knives, and he fell mortally wounded near the door.

"He was hastily carried to the quarters of our friend 
Dr. Bigelow here, who, after he had examined nine or ten wounds, gave up all hope of saving him; and the murderers actually pursued him even hither to complete their work. Dr. Bigelow, however, enraged at their brutality, seized a double-barrelled gun, and pointing it at the blood-thirsty miscreants, threatened to shoot them instantly if they did not leave the room. The gun was not really loaded; but as fortunately they were not aware of this fact, the cowardly assassins retired.

"When the news of the murder of a member of our commission reached our camp, of course we all got into a state of great excitement; and the question was how to get hold of the perpetrators of the deed.

"There was no help to be looked for from the military station; and the alcalde of the town was a weak, sickly man, who had delegated his authority to another, still greater coward than himself; so that no very energetic measures could be hoped from him. All that could be done, therefore, was for all the members of the commission to unite, and do what was necessary for public security. We despatched messengers to San Eleazario, where our chief division lay, to mention the occurrence, and request their assistance ; they all obeyed the summons instantly, and a troop was collected of Americans and Mexicans, who armed themselves, and hastened to Socorro, where a number of the townspeople were awaiting them. Our force was then separated into two divisions, charged to institute the closest search after the murderers.

"We all went to work zealously, every house was searched, and eight or ten of the banditti arrested; though the leader, a fellow of the name of Young, had, 
it appeared, made his escape early in the morning from the place. Our prisoners were carried by an armed party to the house of a magistrate named Berthold, and there kept in close custody while we got together a jury consisting of six of our own people, and six Mexicans. An advocate was offered to the criminals, but declined; probably because they considered the whole affair a mere form, and thought they could easily swear themselves free again. The examination was conducted in the most serious manner, though without any loss of time, as it was rumoured in the place that a plot was forming for the rescue of the villains, and only watching for a favourable opportunity. A more peculiar looking court of justice can certainly hardly be imagined; all who took part in the proceedings, as well as the spectators, who also undertook to preserve order, were armed from head to foot, and composed, in their various costumes, a scene that seemed to belong to the middle ages. The light-complexioned, but sun-burnt faces of the American jurymen, who sat calmly smoking their pipes, contrasted strongly with the dark Mexicans wrapped in their striped serapes, with their broad hats in their hands, and their little cigaritos between their lips. The judge sat before a rough wooden table, on which, instead of legal documents, there lay a pair of pistols ; and the prisoners on a bench, in the midst of the stern determined-looking assembly, had lost nothing of their hardened, indifferent manner, but looked about them with a defiant scowl.

"The trial lasted two days, and an attempt was made by the friends of the prisoners, to delay it still longer, evidently with the view of gaining time to effect their rescue in one way or another. These attempts were 
fruitless, however, and three out of the four were declared guilty, and sentence of death was pronounced upon them, which was ordered to be executed the same evening. A priest was appointed to accompany them to the place of execution, but they rejected his consolations with contempt, and died as hardened villains as they had lived. The setting sun saw three human bodies dangling from the branches of a cottontree; and then all who had taken part in the proceedings, as well as the spectators, retired quietly to their respective abodes.

"In order to get hold of the leader of the band, our society determined to offer a reward of 400 dollars to any one who would produce him, and the reward was tempting enough to send people searching for him in all directions. In a few days the murderer was sent to us in fetters, by the people of Guadeloupe, and we had now the unpleasant duty of inflicting his well-deserved punishment. His trial was short, and he died on the same tree as his accomplices.

"Order and security were now re-established in Socorro ; all whose characters were doubtful, and who were entirely unconnected with the commission, and without occupation, were ordered to leave the place in twenty-four hours ; but the order was scarcely needed, for after the execution of the four most dangerous of the banditti, the rest did not deem a longer stay in the place advisable, and before the end of the second day they had all vanished. Our proceedings were fully approved by the civil and military authorities, and the inhabitants of Socorro thankfully acknowledged that such an example had been long wanting. They could now again sit peacefully before their doors of an evening, 
and were not obliged to retire and barricade themselves in their houses as soon as it began to grow dusk. It is not from the wild Indians New Mexico has most to fear, but from villains of the white race, who have thrust themselves into the country, and become the scourge of the peaceful inhabitants.

"The Mexicans have great, and some of them, unpardonable faults, but they are now generally inclined to an orderly and peaceful way of life."

"I suppose," said one of the party, "we need hardly fear any affairs of that kind in Albuquerque? As Santa Fé is the capital of the Far West, most of the rascality will probably be drawn in that direction."

"I am convinced," said Mr. Garner, "that we have some neat specimens of that kind among our own men. They look innocent enough now, but when we get to Albuquerque, they will most likely be beginning their tricks. You'll see that when once they are dismissed and find themselves their own masters, you will hardly know them again. We shall have to look sharp after our mules, if we do not wish to lose some of them every night, and have them some days afterwards sold in Santa Fé, by persons unknown."

A day's journey fiom the mountains, which had now been visible to us for a long time, we came in sight of a second table rock, very like the first, though of smaller extent; and all doubts were now solved. The Great and Little Tucumcari, between which our route was to lie, were displayed before us; and at Fossil Creek, twelve miles from the mountains, we pitched our camp for the night. The end of the plateau was now-attained; that is to say, the place where it 


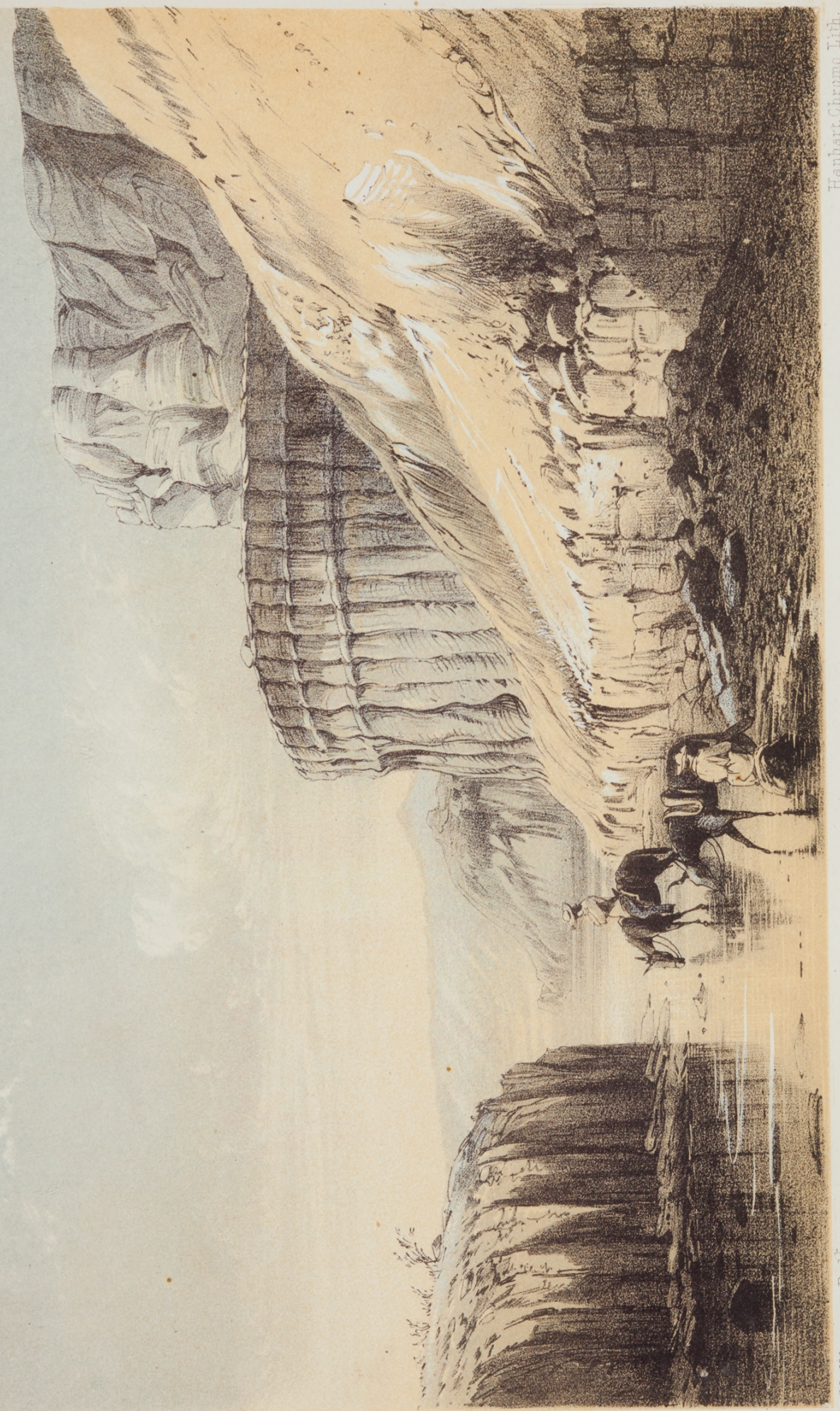

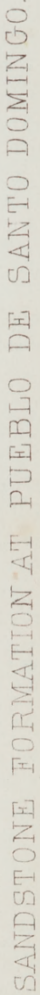



breaks off from the westerly direction it has hitherto kept, and turns towards the south. Fossil Creek is one of the many little streams which have their sources in the ravines of the plateau, and flow towards the Canadian. The name expresses its peculiar characteristic, as its bed is full of fossil, oyster, and other shells; though they do not originate here, but have been washed down from the high land, and rolled on as far as the Canadian; which appears so much the more evident, when you see that the table rock, a few miles westward from Tucumcari, is traversed by a stratum of fossil oyster shells.

At noon on the following day, our train of waggons was moving slowly past the Cerro de Tucumcari, a hill of an imposing aspect, which rises, like an impregnable fortress, 600 feet above the plain. Its circumference at the base may be about four miles; and since the rocky walls rise nearly perpendicularly, it cannot be much less at the platform. The thick bed of white sandstone which lies everywhere close beneath the surface, here frequently crops out, and is for a long way intersected at regular distances, by deep perpendicular cells formed in the course of time by the dripping of water; so that the whole appears as if the huge walls and ramparts, provided with long ranges of port holes, rendered it exceedingly strong. Wherever there is a little earth to afford them nourishment, cedars have sprung up; but under such unfavourable circumstances, they do not attain any thing like their full proportions, but remain dwarfed and crippled, though even thus they adorn the declivities and ravines in a picturesque manner with their dark fantastic shade.

This then was the Tucumcari; in comparison with 
the picturesque shores of the Hudson, or the stately summits of the Alleghanies, not much worth mentioning; but here on the wide plain rejoicing the eye by the regularity of its structure, and setting one to calculate how many thousands of years Nature must have been at work chiselling and dressing these stones, before she could have brought the original rough mountain mass to its present form.

Here, as amidst the wilderness of waters, in the dark primeval forest, among the giant mountains, Nature builds a temple that awakens feelings not easily to be expressed; but the pure joy we feel in the works of the Almighty Master may well be called worship. Even the savage on his war path is not wholly insensible to such impressions, and he does not bow only before the works themselves, but before Him who has placed them there as a token of His power, and whom he calls his Manitoo. The fact that clear springs so often gush out amongst the rocks amidst these grand scenes, inviting the wanderer to rest near them, may even suggest the idea that the hard rock has been thus smote and the water made to gush forth, to detain man the longer before these natural altars.

The Indian, as he lingers there, recalls the vague traditions that have come down to him from a remote antiquity, and which are often to be found amongst different races, and in regions far remote from one another. We find, for instance, the Manitoo Rock on Lake Erie, the Great and Little Manitoo on the banks of the Missouri, the "Chimney Rock" and the "Court House" in the Rocky Mountains, and many other remarkable points in the American continent, which the Great Good Spirit, the Indians say, placed there when 
his Red Children had forgotten him, to lead them back to him ; and when they come to these places they are fond of decorating them with such images as their wild fancies suggest.

At the top of the Tucumcari you are rewarded for the trouble of the ascent, by the wide and glorious prospect offered from the summit of the mountain. To the south and west stretches an irregular range of hills, behind which, in the remote distance, rise the misty blue summits of a higher range; towards the north and north-east stretches the boundless rolling prairie; but as far as the eye can reach there is no trace of the shallow Canadian river to be seen; for it here creeps unseen through the sandy plain; finally, to the east and south-east rises the Llano Estacado, whose far-extending heights lose themselves in the horizon.

Whoever passes the Tucumcari Mountains about noon, will towards evening reach the brook of the same name, and probably pass the night there. So at least it happened with us, and we pitched our camp there on the 23rd of September, having performed a journey of 650 miles from Fort Smith.

The Tucumcari Creek does not rise, as from its name might be supposed, in the hill, but much farther westward in the heights, which appeared to stop the further progress of the Expedition. It must have served the first travellers this way as a guide, for the path ran at a short distance from it, and after proceeding for several miles from our camping place in a southerly direction, turned as did the stream towards the west, and soon led us into a wide level valley, enclosed by rocks and table lands, and opening only towards the west. The question of the probable width of this 
valley was much debated among us, and many assertions were made and contradicted, until at length it appeared that we were all mistaken, and that our calculations were far behind the reality. Looking across the plain to the cedar-wooded hills on either side, it seemed as if a good half-hour's ride would carry one across the valley from one to the other; and it was under this delusive idea that five of us, with $\mathrm{Mr}$. Marcou, the geologist, at our head, resolved to strike off from the path, in a southerly direction, in order to examine more closely the formation of the table lands at a place where a hill of a pyramidal shape was separated from the rest of the range by a perpendicular cleft, and exhibited horizontal strata of the most various colours. We rode on, mile after mile, but the distance before us did not seem to diminish in the least, although the train of waggons, and the numerous figures around them, gradually lessened and vanished. We might have gone about half way, when we found our progress arrested by the Tucumcari Creek, the banks of which were overgrown with reed grass and canes, and great flocks of ducks rose screaming from the water and flew away, exciting our sportsmanlike ardour as strongly as the antelopes on the plain had done ; but when a troop of deer arose from among the high grass, and gazed with surprise at the disturbers of their peace, the foremost of our party could not resist any longer his destructive propensities; and throwing the reins on the neck of his mule, in spite of our dissuasions, he softly raised his rifle, and fired at a fine stag of ten antlers, that had been calmly and innocently gazing upon us. It sprang with all four feet into the air, high above the reeds-a mighty leap, but its last, for it then fell dead on the 
ground, while the rest, terrified at the loud report, fled with precipitation to the ravines.

"I should like to stay here for weeks," said the naturalist, as he cut up the stag; "what sport there must be there down by the river, and in those ravines. I shall really leave such an inviting spot with a bleeding heart." "I would willingly take up my abode here for a long time," said Dr. Bigelow, "for, not to speak of the game, it would be delicious to crawl about under the cedars on the declivities, and hunt for cactus and mosses. There are sure to be plenty of new kinds."

"Nobody would be more glad to remain than I should," observed the geologist, "for besides that the pyramid there before us affords an uncommonly fine example of the formations of the plateau, and one can read the facts on its rocky walls as if they were written upon them, I should like to go rambling about in this glen here and there and everywhere; but we mortals are hard to satisfy."

"For my part," said his young assistant, who was carrying a barometer in a leathern case on his back, and making his mule pick its steps with the utmost care, "I shall be satisfied if I can but get my instruments safely up the hill and down again, after making. my calculations."

"And I shall be content," said the engineer, lastly, "if our lucky sportsman there, does not cut the piece of venison he means for himself so large as to spoil ours."

"You must be content with what you can get," replied the other, laughing, as he fastened the venison to his saddle bow, and away we all trotted towards the pyramidal hill, which, as we approached it, we found to 
be split from top to bottom into two halves, the one half having fallen into fragments, which lay loosely round its foot.

Our attention was strongly attracted by the various colours of the rocks, which lay in thicker or thinner horizontal strata, one over the other, their red, yellow, blue, and white tints, contrasting most strikingly with the dark green of the cedars, which were scattered all up the sides to the summit, where they were overtopped by huge masses of white limestone. These, on examination, appeared to rest on a white layer of fossil oyster shells, belonging to the Jura formation. Towards the north, the Pyramid Rock rose abruptly from amidst these fragmentary masses, and was only accessible on three sides, towards which, after tying up our mules, we betook ourselves, and then began at various points the difficult task of the ascent. At first we got on well enough, and were only delayed when we had been enticed away from the best path by some particularly well-preserved fossil ; but we had hardly got half way up, when we were stopped by loose masses of rock, and rolling stones, that lay in the way. Fortunately, however, the cedars here stood closer together, and afforded us places for the hands and feet to catch by, so that by climbing from bough to bough, we could advance slowly towards our goal. At length, after a good deal of labour, one after another emerged below the summit, and looked about for rough places and hollows in the rock, by means of which we might reach it; and, after seeking long in vain, we discovered, near the precipitous wall, something like steps which afforded an insecure support for hands and feet. Cautiously, and without glancing round, one climbed up 
after another, but no word was spoken the while among us, for each knew that a moment's inattention, and a single false step, might plunge him and the comrades following him into the abyss below. We all, including the barometer, reached in safety the small platform at the summit, and were informed by the instrument that we were still only 500 feet above the base of the rock; but as it terminated in a conical vertex, one needed only to turn round to get a splendid prospect towards every quarter of the heavens.

Eastward we beheld the regular forms and lines of the Tucumcari; to the north the connected table land, stretching out towards the west, and appearing, at the distance of about eight miles off, to join the hilly range that ran southward from the Pyramid Rock. The valley, seen thus from above, did not show the smallest unevenness or variation of surface; and though the autumn had faded the fresh green of the grass, it had lost nothing of its velvet smoothness; and the winding course of the Tucumcari Creek was indicated by the darker colour of the vegetation, and the sparkling of little pools of water in various places.

The long train of waggons and horsemen put us in mind of the Indian representation of the rattlesnake, and it was not without close observation we could make out that it was not standing still, but in slow motion. Our mules were grazing just below us, and we could not help thinking what a fine opportunity it would have been for the Comanche Indians to run off with all five before our eyes. And with this fearful possibility in view, we kept a sharp look-out on every point of the landscape below, where any thing appeared that could be deemed in the slightest degree 
suspicious. We were not destined, however, to any such unpleasant interruption to our enjoyment of the clear pure air and gentle breezes that fanned us upon our lofty seat.

"We may regard ourselves as the monarchs of these regions," exclaimed one of the young men; "and our empire may be considered the largest in the world, for we ourselves determine its boundaries. The countless herds of buffaloes on the other side of the Arkansas are ours, as well as the stags and antelopes below us in the plain; the bear in the mountains owns our sway, and the robber-wolf flies before us; we go whither we will, and we shoot whatever we please."

When the first impression had passed away, we all set to work, each according to his kind, at various tasks. The meteorologist observed his instruments; the topographer made some corrections of his chart; and the botanist, attached to a rope held by his German friend, was let down to gather, at the risk of his life, some precious moss from the perpendicular wall of rock. But after every thing in the way of business had been attended to, we had still spirits for some boyish sport, in which the old doctor most cordially joined his younger comrades. There lay some pieces of rock on the summit, which, as they yielded to our united strength, we rolled to the edge of the precipice, and then down over it; and, after this, all the stones that we could possibly move, were dragged the same way; and we found ourselves well rewarded for our trouble by the pleasure of watching their downward progress; how, after describing a wide curve, they struck on various projecting points, and brought down with irresistible force other portions of the rock into the abyss, with 
thundering noise and commotion, that echoed among the little hills, and made our mules pull anxiously at their tethers, and the curious antelopes start away in panic terror. When there was nothing movable left upon the rocky platform, and the naturalist had carefully stuck a conical bullet at the extreme edge of the rock, with a view of puzzling the next Indian who might come there, we were reminded that it was time to send ourselves down if we intended to sleep in our tents that night. The geologist remained a little while behind the rest, and we heard him hammering away at the top, but he soon joined us; and we scrambled down, accompanied by quantities of rolling stones, mounted our mules, with our pockets stuffed with fossil-shells, and rode off in the direction in which we knew we should find the waggons; for they had long vanished from our sight.

We had to make up our minds to a rather late rest, since, as far as the eye could reach, nothing was to be seen of the Expedition; and we had to look for it behind the blue mountains in the distance. How far it had been found necessary to travel in order to reach the next water, we could not tell, as the sources of the Tucumcari Creek were already left far behind; but it was not thought advisable to hurry our mules, as we had such a long march before us; so we could not reckon on any meal before midnight, unless we had a mind to attack our bleeding venison and eat it raw, which one of the party thought might not have been out of the question if we had had pepper and salt.

"Well, we shall not starve for the next two hours," said another; "but could not somebody tell us a story, and by its interesting incidents make us forget our supper?" 
"The Frenchman shall tell us about la belle France," said the doctor.

"No, for Heaven's sake!" cried the young meteorologist; "his broken English would make my very mule stumble, and then what would become of my barometer? No; I propose that our German friend here should tell us the plain unvarnished tale of his first love."

"There will be no great difficulty in that," said the person addressed. "I need only go on with the narrative of my adventures at Council Bluffs. I have favoured you with the beginning already." 


\section{CHAP. XV.}

CONTINUATION OF THE NATURALIST'S NARRATIVE.-CAMP ON THE LAGUNA COLORADO. - THE GALLINAS. - FLOCKS OF NEW MEXICO. - arrival of the expedition at pecos, and anton chico.

"ONe evening," began the German, "I was sitting before the blazing fire of my friends, Sarpy and Decatur, at Bellevue, on the Upper Missouri, gossipping about one thing and another, and telling them of my adventures among the Ottoes, which were then quite fresh in my memory, as I had been but a short time under that hospitable roof. The room was unusually empty, and only a few Indians were crouching here and there, smoking with stoical composure, and looking as wise as if they understood every word we were saying, when our conversation was interrupted by a modest knock at the door. At the 'Come in' that followed, it opened, and there entered two persons of the female sex, who, by their dress, I saw, to my astonishment, were not Indians.

"They were saluted by my friends with a 'Good evening, Mrs. Alison,' and 'Good evening, Amelia;' and the best place by the fire was offered to them. The salutation was returned in a friendly manner; and after I had been - not very formally - introduced, I sat down opposite to them, and indulged myself with a contemplation of their physiognomies by the bright firelight; for which I hope I shall be excused, when it is con- 
sidered how long a time had elapsed since I had seen a civilised petticoat. I trust, also, I shall not be thought unpardonable, if I regarded the younger of the two ladies, who, as I saw at a glance, was a half-breed, as something more than pretty. For months past I had looked on no other specimen of the fair sex than those unlovely squaws; and this unexpected apparition robbed me of the small remains of understanding that the cold had left. I was bewildered, and thought she must certainly be an Indian 'Medicine girl,' whom it is quite hopeless to attempt to resist. In short, gentlemen, I must confess that the fair Amelia had made such an impression on me at first sight, that all desire for conversation was gone. I wished to do nothing but stare at her uninterruptedly, and see her black eyes raised to mine with an indescribable expression of innocent curiosity. But I shall give you a description of this beauty of the Far West.

"Amelia Papin, who was not yet fifteen, was the daughter of a Pawnee Indian woman, by a Frenchman, who had been long since gathered to his fathers. She had been brought up by a Mr. Alison, who had taken her, as a young child, from the Pawnees, with whom he held frequent intercourse, living a great deal among them, and making many benevolent exertions to instruct and improve them. Mrs. Alison, who had evidently belonged to an educated class of society, and had followed her husband to that country, affectionately sharing all the dangers and inconveniences of such a life, bestowed the same care on the little half-breed as on her own children, and gave her as good an education as was possible in the circumstances; a task that was lightened to her by the natural capacity of the child, 
who took more readily to the manners of her fosterparents than to those of her mamma's relations.

"She had grown up thus to be the charming young" creature now before me. Her dress was simple, but cut in the American fashion, and fitting closely, so as to display a faultless figure. And there was such a natural grace and refinement in her bearing, that I could scarcely believe my eyes when I looked on her dark complexion. The prettiest head you can imagine rested on her slender neck; her coal-black hair hung in two long plaits over her shoulders and formed the setting for her little bronze-coloured face; so sweet a face, that one did not miss the fair complexion, but thought that satin skin, with the tinge of red just visible in the cheek, could not possibly have been improved. The somewhat prominent cheek-bones, indeed, certainly betrayed her Indian origin, as well as the form of the eyes, large and dark as they were, and shaded by long black lashes, but her mouth was so prettily cut, and so fresh and rosy, that I do believe even our doctor here, in spite of his sixand-twenty years of conjugal felicity, would have found his blood running a little quicker in his veins while he was speaking to her. And then between these red lips were two rows of lovely pearly teeth; and she had such a foot, that a pair of her old mocassins deserved to have been sent to the 'London Great Exhibition.' Such was Amelia Papin, the Half-Breed, with whom, as I said, I fell in love upon the spot.

"Mr. Sarpy was always in jovial spirits, and had soon got up a very lively conversation, into which I was continually drawn. There was much laughing and joking, but I did not know very well what about, for my thoughts were otherwise engaged. I saw myself in 
the flattering position of the hero of a romance, and imagined the sensation that would be produced among my friends and relations at home by the news of my marriage with an Indian princess. Of course I desired to produce a favourable impression on the fair Half-Breed in return, and did every thing in my power to place my interesting self in an advantageous light.

"I was delighted to perceive that I had succeeded in attracting the attention of Amelia. Ah! if I could have known what was passing in her little mind! She told me afterwards she had been thinking I was abominably ugly, and that with all that hair about my face I looked more like a buffalo than a man. Fortunately, however, I could not read her heart, and so remained in my agreeable delusion, and went on forming plans for the future, and indulging in the most delightful hopes. The evening passed in this way, and at rather a late hour Mr. Alison came to escort his ladies back to their abode, which was adjoining to the Pawnee Indian Agency. As soon as they were gone, Mr. Sarpy asked me how I liked his niece. He called her so, as her father had been related to him, and he added that her mother had been the daughter of a great chief. 'I saw she pleased you,' he said, ' and you may marry her if you like, but mind, I shall expect at least twenty horses before I give my consent to let Mr. Kenney, the missionary up there in the mountains, join you together. Amelia is a Christian, so I dare say she would not like an Indian marriage.' All this was said in joke, but I took note of it nevertheless, thinking I might have occasion to remind him of it hereafter.

"The next day, as may be supposed, I went to pay a 
visit to the Alison family, who occupied a convenient log house not many hundred yards from our establishment, and I met with so friendly a reception that I repeated my visits very often, and at last almost every day, and I became acquainted there with a great number of Pawnee Indians, who used to come to the house partly to visit their friend $\mathrm{Mr}$. Alison, and partly to look after their blooming young relative.

"I led a pleasant life enough in those days. I used to occupy myself in making paintings in the Indian manner, on buffalo skins, in which art I soon excelled the most accomplished Red-skin, and moreover I got well paid for my work by the Fur Company; and the evenings I generally passed at Mr. Alison's, playing with the children, talking about Europe, and teaching the beautiful Amelia to write English, which she could already do a little. It was soon considered quite a settled affair that I was to marry this young girl, and I was congratulated on the advantage of the alliance, for Amelia, as in receipt of a great number of buffalo hides from her Pawnee relatives, was considered quite an heiress,_-buffalo hides being as good as cash. The worst of it was that the two persons principally concerned, had by no means made up their minds about it. I indeed could easily have gained my own consent, and would have even shaved my head and turned Indian for love of Amelia, but she, alas! did not in the least know what she intended. Sometimes she would offer me her pretty lips for a kiss, and sometimes she would spring away like an antelope, calling me an ugly white man, and a twolegged buffalo, in a way that was not at all flattering. Towards her Pawnee kindred, I really began to cherish quite a brotherly feeling, and used at first to sing 
their praises to her by way of making myself agreeable, but she did not seem particularly interested in the subject.

"The Pawnees, I found, did not at all reciprocate my amiable feelings, but were rather inclined to owe me a secret grudge for my love to their fair flower of the Prairie, of which I had one day a pretty convincing proof; possibly jealousy may have had something to do with it. As the ice on the Missouri began to break up and drift, and the lowlands at the mouth of Papillon Creek became inundated, I made it my chief occupation to go out shooting the ducks, geese, swans, pelicans, and cranes, with which the shallow water was sometimes literally covered. I was accompanied on these rambles by two young Omaha lads, relations of Mr. Sarpy's Necoma, and as worthy good young fellows as could be found under a copper-coloured skin. I had by kind treatment completely gained their affections, and they manifested their attachment in every way they could think of. I needed only to hang on my shot pouch, and there they were at my side with their guns on their shoulders; and their company was doubly welcome to me, for besides forming an excellent body guard, they used to act the part of retrievers for me, and fetch the game out of the water, from the midst of the floating masses of ice.

"One day, however, it happened that I could not find my two Indian comrades, and I therefore set out alone to shoot on the Papillon, about four miles off. I had chosen a good day, for I had scarcely been an hour by the water before I had more ducks than I could carry, and I was just sitting down to rest upon a stone when an Indian suddenly made his appearance and in 
a very rude way asked me to give him some powder and shot. I had seen the fellow, a full-blood Pawnee, before at Mr. Alison's, and had then been by no means pleased with his manner towards me, for he did not take any pains to conceal his ill-will at my attentions to the fair Half-Breed. Now, therefore, when he stood thus suddenly before me, I hastily put a percussion cap upon my piece, and then refused his impudent demand, telling him that his arrows would go off very well without powder and shot. He continued to urge his request, but to no purpose; and at last he went off, repeating several times an English oath-the only word of English he could speak - and entering the woods was soon out of sight. I laid my game down by the stone on which I had been sitting, and began to shoot again; taking care, however, though I had no particular fear of the Pawnee, not to fire off both barrels at a time. At last, being completely laden with booty, I determined to turn homewards, and sauntered towards the place where I had left my ducks, but when I reached it, found that they had vanished, leaving no trace behind. Surprised and provoked, I was looking round for a moment, when something stirred among the boughs in the wood that separated me from the Papillon, and at the same instant an arrow entered my thigh. I took aim in a moment at the spot whence the arrow had proceeded, but the treacherous Pawnee - for it could be no other-had hidden himself so cunningly behind the trunks of the trees, that he remained invisible to me. I could not go in pursuit of him, for it was necessary to lose no time in getting the arrow out; and as, fortunately, it had not gone farther than just to the bone, I was able, by a vigorous wrench, 
to get rid of it, though the wound immediately began to bleed abundantly. The Indian rascal profited by the unguarded moment in which I was thus engaged to step from his hiding-place and glide away, but I sent a message after him that I flatter myself he will not readily forget. I fired both barrels of coarse small shot, and though he was a good way off, I am certain I scarified his smooth back as nicely as the doctor ever did that of a patient. After I had washed my wound with the icy water till the blood ceased to flow, I took my game and my gun, and the arrow with which I had been shot, and went home in a very ill humour, though I could not help secretly rejoicing in the thought of how I should be pitied by the fair Amelia for my misfortune. On the same day I informed the two young Indian brothers, Hug-ha, and Schu-gree-ga-gee, of my adventure, and they commented upon it with their natural sagacity. They pointed out that the Pawnee could not have intended to kill me, or he would certainly have used a barbed arrow; he would also, in that case, have taken care not to use an arrow marked with the symbol of his tribe, by which it would be rendered easy to discover the perpetrator. I was willing enough to pass the matter over and treat it as a sort of rough joke; and I thought at the same time I would take what care I could in future not to awaken hostile feelings in the Pawnee mind. The wound soon healed, and I pretty well forgot all about the matter, but it had had the effect of making me more cautious; and I took good care not to go anywhere where I might expect to meet with thievish Pawnees without being accompanied by the faithful Hug-ha and Schu-gree-ga-gee. The dark eyes of the charming Amelia had really glittered with tears 
when she heard of my being wounded, and flashed fire at the treachery of the Pawnee. I really think the delicate creature would have stuck a knife into him had he just then come in her way; but the storm soon blew over, and we resumed our harmless talk about my distant home, whither, when I had made a considerable fortune, I was to convey her. Fantastic dreams these, doubtless; such as we take seriously enough in youth, but think of in after years but as the sports of a sickly and childish fancy.

"The days flew swiftly on; I was once more in possession of my customary iron health and strength, and I began to consider whether I could not render my outward man more attractive in the eyes of the fair. With this view I set to work some of the most skilful squaws, and in a short time my entire suit of leather habiliments, from the round hat that covered my well-oiled bushy hair to the soft mocassins on my feet, was decorated with the most elegant embroideries and fringes. My pistols, war hatchet, and knife, which I carried in a girdle beautifully worked by Amelia, were thickly set with brass nails, and in short, if I was not irresistible, it was not my fault. I became more and more reconciled to the thought, that as my two years' leave of absence from my native country had long since expired, my return was cut off; so that there was nothing left for me but to pass for dead, and remain in the steppes hunting buffaloes; an arrangement that appeared to me more decidedly agreeable than returning to Prussia to be punished. Here I worked but little and earned a good deal, while there I should have to work very hard for very bad pay; a state of things that seemed by no means preferable. I there- 
fore set about seriously considering the question of settling permanently on the Missouri."

Here there was a pause in the narration, and we halted and looked about us. We had reached a spot where the valley narrowed very much, and then suddenly spread out very wide again. It was the Laguna Colorado, a valley with a shallow pond at its western end, which, in the rainy season, overflows its banks, and turns the whole valley into a lake, whose waters are dyed of the same red tint as the clay they cover; whence the name given to it by the Mexicans. At the time when our expedition reached it, the valley was perfectly dry, and we saw that the whole extent of it, a length of five miles, must be traversed before we could hope to find water, and the camp pitched by our companions. The sun had disappeared behind the grey hills; and twilight rested on the dry bed of the lake, which lay, with hardly a sign of vegetation, dreary and dead before us. We continued our march, allowing our mules to follow the fresh tracks of the waggon wheels, which also led them to the most convenient places for crossing the various little clefts that intersected the valley. The evening air was damp and cool, and narrow streaks of cloud rested on the plain, and darkened the ravines, where the hooting owls were leaving their abodes in the rocks, and the grey fox stealing from his covert under the boughs of the cedar, to pursue their prey on the plain.

In a short time we rode on, and the naturalist continued his narration :-

"I now began, as I said, to think seriously of settling at Council Bluffs, and on that account entered into a negotiation with Mr. Sarpy, who thought it particularly 
to my credit, that being only twenty-four years of age, I proposed to take a companion for life. A married man, he observed, was much more to be relied on, than a bachelor, in which he was certainly right enough ; and if he did not positively encourage me to this step, he certainly offered me, in the most friendly manner, his assistance to place myself in such a position as should set me at ease as to the future, and at the same time make me useful to the Fur Company. But I must give you some idea of the locality, or you will hardly understand the peculiarity of my position. The distance from the mouth of the Nebraska or Flat River, to Belle Vue at the southern point of Council Bluffs, is about eight or ten miles; and precisely in the middle between these two points, lies an island in the Missouri, about four miles in circumference, and overgrown principally with willow, but also with a few oaks and birches, in the shade of which, as well as in the open spaces, rich grass grows in abundance. Judging by the trees, it can hardly be more than seventy years since this island began to rise above the surface of the water. The turbulent river, which brings down at the time of the floods immense masses of drift wood, mud, and sand, has continually been paying tribute to the island, has increased it to its present extent, and is still going on with the work. It will ultimately have carried away a bend above Belle Vue, and will then, from causes easily to be explained, turn the whole force of its current into the channel at the east side of the island, and stop up the western one, so that the island will at last become incorporated with the main land. Many years will doubtless pass before this change is completed, but it is merely a question of time, and 
there are evidences enough that the Missouri at Council Bluffs has been continually changing its bed, which is there six miles broad; that it at one time washed the base of the rocky hills, from which it is now several miles distant, and that it is undermining and wasting away large tracts of the opposite shore. Well, it was this island that Mr. Sarpy had selected for a particular purpose, and also destined for a residence for me.

"Besides his barter trade, he had long been practising cattle breeding, and in the course of years had accumulated considerable herds. During the year, this cattle was fed in the neighbourhood of the Fort, but in the spring they were driven over to the fat pastures of the island, and remained there till the Missouri froze again. Many of them were every year killed by the Indians, and found their way into the smoky wigwams, where such rare dainties were exceedingly welcome, and consumed in brief space. Mr. Sarpy, however, much desired to put an end to these depredations, and he therefore made me a proposal which I thought ought not to be hastily rejected. He explained his plan to me, as nearly as I can remember, in the following manner : 'I will build you a log house in the middle of the island, upon the highest point, and there you and your Amelia and as many squaws as you choose to marry besides, may live very comfortably. You shall be provided with a light canoe, in which you can row over to Belle Vue whenever you want provisions, or any thing else, and in return for your living on the island and protecting it, and thus frustrating the thievish intentions of the Indians, I will secure you a certain salary, which you may easily double by painting buffalo hides. 
You will, of course, be abundantly provided with powder and shot, as well as with some of my best dogs. You can tie up one at your door, and let the others run about, and they will be sure to let you know when there any Indians coming. You will find good fishing on the island, and capital sport with the thousands of water fowl that come to the sand banks. The cattle, I dare say, will flourish under your care, and, in short, you will have a splendid time of it.'

"I signified my unconditional consent to the proposal, - this Robinson-Crusoe life was what I had long been wishing for; the only thing that appeared to me awkward in the arrangement was, that if it should happen that I found myself under the necessity of shooting some of the Red-skins, their friends might combine against me, and easily find an opportunity of falling upon me and my wife or wives, and helping themselves to our scalps.

"On the whole, however, I agreed to go and take my chance; but the beautiful Half-Breed was not in the least inclined to share with me that charming solitude-indeed, declared roundly she would not; my threat of marrying a multiplicity of squaws did not seem to alarm her at all - and so we quarrelled and then made it up again, though at a vast expense of sweet words on my part. I secretly hoped that in time she would yield to my wishes, but I refrained for a long while from any further allusion to the subject.

"In the meanwhile the last ice had been carried away by the muddy waves of the Missouri, and given over to the Mississippi for complete solution; the buds on the trees began to swell, immense flocks of birds were seen flying towards the north, crowds 
of emigrants assembled at Belle Vue, to proceed to Utah Lake or California, and I too began to be conscious of a revival of my old desire for travelling. I used to contemplate with melancholy feelings the troops of merry or busy adventurers preparing for their journey, and gaze with a kind of doleful longing at the birds as they flew with joyous cries over my head. How gladly would I have followed them! I thought of my lonely island, I thought of the golden freedom that I was about to sacrifice, I thought of the great and glorious world that I would so gladly ramble about in all directions, and my love for the fair Amelia began to totter! As if, too, to increase my doubt and irresolution to the utmost, an advantageous offer was now made to me by some wealthy Mormons. Some of the principal persons in the caravan now assembling at Belle Vue had it in contemplation, it appeared, to engage me as a buffalo hunter. They offered me a high salary, but I remained firm; they opened to me the most tempting prospects for the future, and even brought in the attractions of some charming Swedish and Irish girls of their party to add strength to their persuasions, but I resisted heroically. Could Amelia have been persuaded to accompany me, and become a Mormon, I might perhaps have consented; but she appeared extremely shy of the new sect, and I certainly had no intention whatever of renouncing the religion in which I had been brought up. 'But we will not ask you to be converted,' said a Mormon elder; 'you shall only render us certain services, for which you shall be paid; you know the road to the Rocky Mountains, you will be able to show us the best camping places; and we will buy from you every buffalo that you shoot, and give you our best hunter to ride.' It was really a 
tempting proposal to an enthusiastic sportsman. I looked at the beautiful horse, whose limbs seemed made for the race; I jumped on his back, and laid my pistol between his ears and fired; and he only shook his head slightly, to intimate his disapproval of the proceeding. In my delight I exclaimed to the tempters that 'I would consider of the matter.' As I walked home, I felt as uncertain as a child as to what I should do; and I could not but admire the knowledge of human nature shown by the crafty Mormons. The sight of the fine horse had produced more effect than their money and fair words put together. I compared the monotonous existence on the island with the exciting vicissitudes of the life on the steppes, Mr. Sarpy's tame cows with the wild bison, and I certainly never felt less desire to settle than at that moment. 'I am too young,' I said, by way of excuse for myself; and moreover, I added philosophically, 'Amelia is much too young to marry.' Mr. Sarpy was certainly in the right when he said 'a married man was more to be relied on than a bachelor.'

"My only anxiety now was, in what way to make known the alteration in my plans; but an unexpected occurrence came to my assistance. Immediately after my arrival at Belle Vue, I had sent several letters down the Missouri by the Indians, and one at least had reached its destination, St. Louis. After the lapse of three months I now at last received a reply, and that at the moment when I most needed it. It contained news of the former companion of my journeys and my sufferings, who had found his way to New Orleans, having long given up all hope of ever seeing me again in the land of the living, and closed with the request that I would take a passage in the first steam-boat coming down the 
Missouri, and join him at New Orleans, where he was waiting for me. Letters of credit were inclosed, so that there was no obstacle to my departure; and the steamer which had brought me the letter was to leave on its return voyage on the following morning.

"I thought no more now of the Mormons and their offers, but visions of the tropical Louisiana, and of crocodile hunting on the Atacapas, took possession of my brain; and I hastened to Mr. Sarpy, informed him of all particulars, and was rejoiced to find that he seemed to be quite of my opinion, and to recommend my speedy departure. As soon, therefore, as I had arranged my other affairs, I went over to Mr. Alison's, intending to pass a few hours there, and to take, perhaps, a last farewell of my Indian love.

"It passed off much more easily than I had anticipated. I entered with the letter in my hand, with, I believe, a very embarrassed countenance, and spoke falteringly of the impending separation. 'Oh! how glad I am,' cried Amelia, with the most unmistakable expression of amiable pleasure; 'I was so afraid I should have to go to that island with you.'

"'But when I come again?' said I, hesitatingly. 'Oh! when you come again,' answered the Half-Breed, 'if you are not married, nor I either, it will be time enough.'

" 'So be it,' exclaimed I, joyfully, and assuring her that she was the best girl in the whole world. I cannot deny, though, that I did secretly feel rather provoked, that instead of the sentimental scene I had contemplated, the whole family seemed so uncommonly cheerful about my departure.

"The steamer in which I was to take my passage was 
an old, shattered, worn-out thing; for which reason the captain had engaged at St. Louis a band of musicians, who were now playing away merrily on the landingplace to attract passengers. This is no uncommon speculation; for it is found by experience, that the traveller of the Far West will rather pay a high fare to the worst boat with music, than the best without. The musicians on this occasion happened to be Germans, and with the help of some good liquor, of which there is seldom any deficiency in these steamers, I persuaded them to give my lovely Indian a parting serenade. After taking a cordial leave of my friends, I gave a last kiss to Amelia, dashed a tear from my eye, and hurried down to the landing-place, where a crowd of Omaha Indians were assembled, contemplating the great fire-breathing canoe.

"There was Onga-tonga, the Great Stag; and Ohaginga, the Little Cook; and the 'White Cow;' and the 'Yellow Smoke,' and many others of the Omaha aristocracy; and I was embraced and kissed by the naked warriors, till my face exhibited specimens of all the variegated colours of their paint. 'All right,' cried the steersman from his lofty seat-'All right,' answered Decatur and his people from the shore. I sprang on board, the bell rang, the paddle-wheels lashed up the sandy water into foam, and the boat was soon in the current, and driving merrily down the Missouri.

"I stood long on the deck looking towards Belle Vue, where the figures of the Indians were clearly distinguishable as they moved round a bright fire; the panting steamer glided past my lonely island, and as if a dark curtain had been drawn, it hid from me the distant lights of the place where I had left so many friends, and, moreover, my Indian love behind. I carried 
away with me, however, a recollection of happy days that will last me my life."

Here the narrator terminated his long story; it had grown quite dark, and we rode on in silence, no longer able to distinguish the track of the waggon-wheels, but relying on the instinct of the animals to find the way. After a while, the slipping of their hoofs, and the splashing of water, made us aware that we were no longer on dry ground, but getting into a morass, or small lake. Shrubs and bushes closed more and more around us, and we were beginning to feel doubtful whether we had taken the right path, when the glimmering of fires pointed out the direction and vicinity of the camp. We urged on our mules, whose steps now again sounded upon hard ground, and before long a loud "Who goes there?" was heard from one of our sentinels.

When we looked about us on the following morning, we saw that we were encamped at the foot of a range of red sandstone hills, and that the whole valley was inclosed by rocks of a similar character, more or less overgrown by cedars and dwarf-pines, whilst here and there, amongst irregular fragments of sandstone, arose those urn-like formations, which in the distance resemble ruins. The small lake, through which a stream wound its.way, was now dry over the greater part of its bed, and the shallow water was thick and of a brick-dust colour, so that the coffee made before the Expedition started again looked like strong chocolate, though it had not, in taste, the remotest resemblance to that agreeable beverage.

Rough, uneven country, small, pleasant prairies, naked rocks, cedar-wooded hills, and rounded fragments of sandstone-these were the features of the 
landscape on either side as we pursued our way in the old direction towards the west.

We found ourselves now on the dividing ridge or water-shed between the Pecos and the Canadian, and at a height of 5550 feet above the level of the sea. The Hoorah Creek, at which we rested for a day, was the first stream we had crossed that carried its waters towards the Pecos, and the immediate connection with the Canadian, that had so long served our engineers as a guide, was cut off.

There was now a difficult tract of country to be examined, measured, and topographically surveyed. The difference of level between Fort Smith and the above-mentioned water-shed amounted to 5000 feet; but the ascent was distributed over a surface of 700 miles, and, with the exception of a single place at the Llano Estacado, was so gradual, that it would form no obstacle to the laying down of a railroad. Our Expedition was, however, still at a distance of 150 miles from its place of destination, Albuquerque on the Rio Grande, and in this short tract, up to the water-shed of the Pecos and the Rio Grande, it would have to work up to a height of 7000 feet (the average elevation of the high table-land eastward of the Rocky Mountains above the sea), and then down again to the Rio Grande, whose level at Albuquerque, or Isleta, is 2000 feet below that water-shed, or 4945 feet above the sea.

In order, if possible, to discover a suitable pass, one part of the expedition was to have followed the Pecos, perhaps to its source, thence proceeded to the source of the Galisteo, and afterwards followed the course of this stream to its mouth in the Rio Grande; but this plan was given up when it appeared that the Pecos, further 
up, breaks its way through a narrow rocky valley. Our party, therefore, remained together as far as the pass of Cañon Blanco-two days' journey westward of the place where we crossed the Pecos.

The inequality of the ground was especially striking, when, on the 25 th of September, our Expedition reached the Gallinas, a few miles above its union with the Pecos, and had to descend a considerable depth into a valley, and then toil up again as high on the opposite side. The sources of this river are not far from those of the Pecos, therefore only a little eastward from the foot of the Santa Fé mountains. As both rivers run through this tract in the same direction, increase at nearly the same rate, and unite in an acute angle, the Gallinas might fairly be considered as a branch of the Upper Pecos.

The banks of the first are low and bare, and this is, perhaps, why travellers are apt to regard it as a mere brook; but if you stand by the side of it, and see that its breadth varies from twenty to fifty feet, and that its clear flood rolls briskly along over its smooth pebbles, dashing vigorously against projecting banks, rebounding from the hard walls, and throwing up foam and bubbles on its surface, you will wonder how such a pretty river comes to be wanting in the ornament of a luxuriant vegetation-why no rich foliage is reflected in its bright waters, and no stately trees protect the lonely Mexican shepherd from the almost perpendicular rays of the sun. On the arid gold-bearing sands of California there are trees that tower to the skies, and gigantic cacti draw their nourishment from the black trap rock, and the cold lava of extinct volcanoes; but on the fruitful soil of 
the rivers of New Mexico there is seldom so much as a solitary cotton-wood tree to be seen.

The closely-cropped grass now told us, almost as plainly as the sight of the flocks and herds at a distance, that we were approaching the settlements; and we had scarcely reached the high western shore of the Gallinas valley, when the air seemed filled with a confused murmur, that became louder as we advanced, and the sound of thousands of animal voices was mingled with the tinkling of many bells from an enormous flock grazing in a valley that we were passing. A flock of sheep would certainly not have attracted much attention from any one of us at home; but now it was such an unwonted sight, that probably there was not a single member of the party that did not turn to gaze with interest at the five or six thousand sheep and goats that were bleating and baa-ing in chorus, while the stately bearded rams and he-goats made, with their horns, threatening demonstrations at the waggons.

A young Mexican lad, with wild black hair hanging over his brown face, stood leaning on a knotted stick. His naked limbs were covered with weals, and the few rags that served him for clothing were the very symbols of destitution; a lean wolf-dog that lay at his feet glanced suspiciously towards the strangers, but the ragged Mexican politely raised his remnant of a straw hat, and held it in his hand, saying, "Buenos Dies, Señores!" The salutation was courteously returned, and as some of the party appeared desirous of asking him some questions about the character of the country, he threw his tattered blanket 
across his shoulder with the stateliness of a hidalgo, and modestly stepped forward to meet the strangers.

According to his account, it might be about six miles to a spring, where the Expedition could pass the night, and then on the following morning we should have six miles further to reach Anton Chico, the first settlement. Many rather unmeaning questions were put to the lad, most of which he answered with a Quien sabe? (Who knows?) and when we left him again to his solitude, we could not help grieving over the lot of these poor fellows. With no other provision than a bag of maizeflour, they leave their customary shelter, under the rough wooden verandah of the first house they come to, and follow their flocks for weeks, or even months, without seeing a human creature, unless, perhaps, at a distance, another shepherd, with whom they are forbidden to join company, to avoid the mixing of the flocks under their respective charge. Their only amusement is afforded by a surly dog, or some pet lamb of the flock, and the only interruption to the dreary monotony of their existence is the occasional unwelcome one of an attack by wild Indians, who rush down and plunder their flocks, even if they do not murder them.

We were glad to turn our attention to the more agreeable images suggested by the sight of the blue summits of the mountains of Santa Fé, which now rose above the grey table-land - those misty heights of the long Cordillera, which, as a schoolboy, I have often pored over on the map, when to visit them seemed an unattainable happiness.

The nearer our expedition approached the spring, the more was our route intersected by deeply-trodden 
paths, which, however, all led to the water. Dappled cows lay quietly here and there, with curious antelopes, who in this region seem to know no fear, sporting about them. But, alas! a travelling American is not such a harmless animal as a Mexican shepherd; and many a rifle pointed at the poor antelope, destroyed at the same time the innocent pleasure of the lonely herdsman, who would, perhaps, often have given the best sheep of his flock to redeem the wild companions that had become so familiar and friendly.

As soon as the tents were pitched by the spring, Lieutenant Whipple took leave of us, and set off in a light conveyance for Anton Chico, to announce the coming of the Expedition; and though savoury venison was frying at all the fires in the camp, and a clear spring was bubbling out of the ground a little way off, every one was impatient for sunrise, that he might be soon on his way to the town. After a short march over stony heights covered with pine woods, the country opened, and afforded us a view over a valley inclosed by high rocks, with the Pecos winding through it. Here the road divided; one way turning off in a north-westerly direction to the table-lands on the Upper Pecos, and then crossing the river at San Miguel, led towards Santa Fé; whilst the other lay immediately along the Pecos in an opposite course. By this last the Expedition travelled conveniently down the river; and after crossing it, we found ourselves at only a short distance from the frontier town of Anton Chico, which looked, as it lay before us in the plain, uncommonly like a collection of brick-kilns. A suitable place was soon found for the encampment; and after the cattle had been driven away to pasture in some grassy 
ravines (for the immediate neighbourhood was like a dusty threshing floor), every one arranged his domestic establishment under a waggon tilt, or in his tent, and then set off to walk to the town, and find means, between broken Spanish and whole English, to scrape acquaintance with the Dons and Señoritas; as well as to ask some interesting questions about the prices of fowls, eggs, milk, butter, and of some drink a little stronger than water. 


\section{CHAP. XVI.}

ANTON CHICO. - A FANDANGO. - DEPARTURE. - CAÑON BLANCO. THE WATER SPOUT. - GALISTEQ. - FITZWATER. - VOLCANOES IN NEW MEXICO.-CAÑN BOCA.

Anton Chico, though an old settlement, has never counted more than three hundred inhabitants. The situation is not happily chosen, since, whatever commerce goes to Santa Fé - the chief commercial town of the West - can only reach this town by a circuitous route; and the environs are too little favoured by nature for agriculture ever to become a chief source of maintenance to the inhabitants. The few houses, which are inhabited by herdsmen and shepherds, are built of large square masses of unburnt brick (adobes), and make not the smallest pretension to beauty without, or convenience within. There is a church in the same style of architecture, and near it a Fandango Saloon,fandango being the name here given to every kind of dance or ball. The space between the houses and the Pecos is laid out in gardens and maize fields, which require artificial irrigation; and this is effected by little trenches, or ditches, that run near one another through the fields, and answer the double purpose of bringing water from the river to the fruit-trees in the dry season, and carrying the superfluous moisture down to it during the heavy rains. These precautions are indispensable if any harvest is expected from the heavy clay soil, which, in the dry season, is as hard as a rock, and 
in the wet reduced to a toughly tenacious paste. The river Pecos has considerable resemblance, in character, to the Gallinas, though it is somewhat broader and deeper. The high table-lands which inclose the valley to the north keep off the cold stormy winds; and the chief trouble of the inhabitants proceeds from the wild Indians, who from time to time make their appearance and levy a forcible tribute on them.

The arrival of our party drew the entire population of the adobe houses to their flat roofs, or out of their doors, whence they contemplated the strangers with much curiosity. Our inquiries about shops were soon answered, and our men swarmed about them like bees, to get rid of the few shillings in their possession as quickly as possible.

Lieutenant Whipple had been the day before received into the house of an American, settled here, and married to a beautiful daughter of the land; he received us himself, and introduced us immediately to the first magistrate of the place, namely, the Alcalde. He was a broad-shouldered, genuine Mexican, all politeness to visitors, and marching about in the most stately manner in his shirt sleeves. He raised his broadbrimmed sombrero with a graceful, but somewhat theatrical, air of dignity, that would have done honour to the proudest grandee of Spain; and as his deportment was as condescending to the people of the place as it was obliging to strangers, we could not but be profoundly impressed with the importance of his person and office. We returned, at a late hour, to our camp, laden with treasures; and all the delicacies of the season in Anton Chico soon found their way into our field kitchen, with the exception only of red pepper. 
Garlands of this red pepper, or capsicum, were hanging to dry on the outer walls of the clay houses, and decorated them to profusion; but, to the great astonishment of the Mexicans, their American visitors mostly declined it as a condiment; and what was still more surprising, those who had been induced to try this curious and unaccustomed enjoyment were punished by a swelling of the mouth and face; so that we came to look with ill-will on the beautiful scarlet fruit so much in favour with the Mexicans.

On the following day, the Alcalde presented himself as early as possible, in company with the most distinguished citizens of Anton Chico, to give our whole party a solemn invitation to a fandango, to be held in the evening; and it is needless to say the invitation was joyfully accepted.

We all set to work directly to rummage up the most elegant ball costume that circumstances permitted; needles and thread were seen in brisk motion in all quarters, and chasms and openings in our well-worn garments, originating either in accident or in severe service on our long journey, disappeared as if by magic. An artificial black was, for the first time for many days, superinduced upon our chaussure; and the most gorgeous shirt collars and fronts were manufactured out of stiff drawing paper.

We were a comical-looking troop, nevertheless, when we set off in the evening to the festive scene, being summoned thereto by the church bells, which are obliged to accommodate themselves to the double duty of calling people to Divine Service and to the fandangos. Some of us, who wore a somewhat creased, but extremely fashionable, hunting coat on the upper part of our per- 
sons, terminated in leathern leggings and heavy boots. Others showed civilisation on their lower extremities, but a decided tendency towards savage life at the top. The majority boasted the paper linen I have mentioned, and there was even one pair of white kid gloves seen among us, though with considerable apertures at the seams, through which the sunburnt hands became visible. The wearing of arms at the ball was expressly forbidden, but one did, nevertheless, occasionally see the brown end of a revolver, or the bright blade of a bowie-knife gleaming out. In this picturesque attire we betook ourselves to the building erected for public purposes next to the church, and having obtained at the doors some very bad refreshments for very good payment, we entered a long narrow hall, where we were welcomed by the Alcalde and a crowd of Mexicans in laced calcineros, and of Mexican fair ones in thick veils or light shawls; and the various nations were soon mingled together, and doing their utmost to understand and be understood. Their efforts were not particularly successful, but the tongues went merrily, the black-eyed señoritas made delicate cigaritos, which they lighted and offered to their visitors, the whiskeypunch went briskly round and the orchestra, consisting of two guitars and a violin, soon summoned us to the waltz.

The dancing began, the pairs moving at first in a serious and deliberate manner; but the stately magistrate, in his shirt sleeves, gave the musicians a sign that accelerated the movements of their fingers, and of the feet of the dancers on the dusty clay floor. The bright-eyed señoritas were indefatigable, the degenerate descendants of the Spaniards looked with evident complacency at their 
own nimble limbs, and the wildest excitement gleamed from the bearded visages of the Americans. There was not a single dance in which they did not take part, and in defiance of all rules of art and fashion; but setting to work with a will, they maintained their places in the most complicated operations.

The Mexicans regarded with a kind of compassion the awkward movements of our fellows, and the confusion they created in the figures; but the laughing fair ones did not seem at all distressed by them, but during every pause rolled up little cigaritos, began to smoke them, and then presented them, with an amiable smile, to their partners, who could only accept them with a "Thank you," and "Ah, if I did but know a little Spanish!"

The impossibility of communication between the various nationalities did not seem at all to check our merriment. We danced, and sang, and laughed, and drank, and did not go home till morning, but then, happily, without the mirth having been interrupted by any quarrels, or broken heads, which was the more praiseworthy, as waggoners and soldiers (among the latter specimens from all the nations of Europe) had thought proper to join in the revels, and that moreover with unsteady feet and cloudy brains.

When the sun shed his first beams on our camp on the following morning he found every thing perfectly still, and only a loud snoring, from the interior of the tents, announced that the members of the Expedition were enjoying a refreshing slumber after the bodily fatigues of the night and the spirituous indulgences that had fallen to their share.

Laziness seemed to hold undisputed sway over the 
whole valley of Anton Chico. The cocks crowed in the little town, and the mules neighed in the distant ravines, but their tones struck no other ear than those of the sentinels, who, leaning on their muskets, were doubtless making sorrowful reflections on the hard fate that had debarred them from sharing in the delights of the last night's festivity.

On the morning of the 29th of September, our second day at Anton Chico, Lieutenant Whipple divided the Expedition under his command into two parties, to proceed by, and examine, two different routes to Albuquerque.

$\mathrm{He}$ himself, in company with a topographer, the geologist, the botanist, and myself, proposed to visit the valley of Cuesta, and then to meet the rest of the expedition at the end of the Cañon Blanco. After this, we were to turn off in a north-westerly direction, leaving the Gold Mountains to the south, touch on the town of Galisteo, following the bed of the stream of the same name, meeting the Rio Grande at the Pueblo town of St. Domingo, and then to go down the river to Albuquerque. The main body was at the same time to travel in a straight line southward from the Gold Mountains, through the little town of St. Antonio and the San Pedro Pass, to our common destination; where, according to a rough calculation, they would arrive two days sooner than we should.

"Good-bye till we meet again at Rio Grande," called out Lieutenant Whipple, as with two waggons and five soldiers, our little troop set out; and "Good-bye till Albuquerque," was called in reply by the party, which was then preparing to leave the valley of Anton Chico.

The rain which had fallen on the preceding day and 
during the night had been followed by oppressive heat, and since, during the first hours of the march, it was necessary to ascend to a considerable height; the beginning of the journey was far from pleasant, and at the elevated point, where we had to turn off northward from the high road to go to Cuesta, the stony ground, and thick growth of crippled cedars, hindered our progress greatly. Late in the afternoon we reached the edge of the valley of Cuesta, which being of formidable depth and inclosed by high rocks, presented a very imposing aspect.

A few steps from the spot where a narrow and dangerous path led down into it, our camp was pitched; and Lieutenant Whipple went down with one of the waggon-drivers to the settlement below to buy some maize for the cattle, who had for this night to dispense with water, whilst we climbed about the heights to look for favourable points from which to view the picturesque landscape. High yellow table-lands, traversed by white horizontal layers of chalk, bounded the valley, which was divided into gardens and cornfields in right angles, so that it looked like a web. The river Pecos flowed in many windings, through the bottom; and the town of Cuesta lay, like a little fortress, on a lower step of the plateau. Besides this, various larger or smaller settlements lay scattered about like dice, sometimes peeping from the mountain ravines, sometimes lying further out on the level part of the valley. We were looking from a height of about 500 feet above the Pecos, so that the whole scene was spread out like a map in relief before us. There were only a few shrubs on the banks of the river, and here and there a cotton-wood tree, which the 
autumn had obviously touched without having robbed it of its beauty; but the most picturesque features of the landscape were the light cedar woods on the next table-land: behind this high, dark blue mountains and massive rocks; and these again far overtopped by a loftier, more distant range, whose light airy blue peaks were scarcely distinguishable in the clear atmosphere. Below, in the valley, the twilight had begun to gather, but the sun still illuminated the mountain summits, and kept them long bathed in rosy light.

As it grew dark, we assembled before the tents under a thick group of cedars; logs of resinous pine-wood nourished a merrily crackling, blazing fire, round which the little party lay gossiping, and awaiting with some impatience the return of Lieutenant Whipple, to do honour to a frugal supper. "If we only had the engineer with us," began the geologist, "we should be the same party that visited the PyramidRock on the other side of the Laguna Colorado. Bythe-by, some of us thought we were the first whites who had ever visited that rock; but when I remained behind on that projecting point, I discovered a certain proof, not only that whites had been there before, but that they had visited the place recently. I found a conical bullet, which had evidently been placed there intentionally as a memorial, and I brought it with me by way of souvenir."

The doctor and his companion, of course, enjoyed this discovery amazingly, as they happened to know that the bullet had lain there about five minutes; but before we had done laughing, our sentinel hurried in to tell us something that put a stop to our merriment for the moment. He had heard several shots fired at the 
foot of the mountain, and as Lieutenant Whipple had not yet returned from his excursion, and we were well aware that many of the Mexicans owed no good-will to the recently victorious Americans-the intelligence awakened no little anxiety. Every one shouldered his arms in a moment, and leaving only two men with the cattle and waggons, hurried in the pitch darkness down the steep and dangerous path into the valley. The abyss yawned black before us, and appeared still blacker and deeper from the glimmering lights visible here and there in the scattered houses; but the sound of another shot, heard faintly, as if from a distance, settled any hesitating doubts we might have had. We drew our belts a little tighter, and rushed forward, without knowing precisely where to hit the right path in the darkness, and without troubling ourselves about the rolling stones. Down we went-half sliding, half fallingrepeated shots spurring us on, on our dangerous path, until at length, panting and exhausted, with torn clothes and bleeding limbs, we gained firm footing on a broad road that led in the direction to which we were summoned by more shots and loud cries. We advanced in double-quick march, but in close order, till we reached the first houses of the settlement, when we could see in the shadow of the rocks some men advancing towards us.

"Who goes there?" cried one of our martially disposed party; and his exclamation was accompanied by the clicking sound produced by the cocking of half-adozen rifles and revolvers.

"Why, you are not going to shoot me, I suppose?" was the answer, in the voice of Lieutenant Whipple, 
who, perfectly safe and sound, was returning to the camp, accompanied by some Mexicans and laden mules. Explanations followed on both sides; and it appeared that the lieutenant, though he had had ill-will enough expressed in looks, and even in words, had not come to any open hostilities, and that the shots and cries had proceeded from a merry party who had been terminating a fandango in this not unusual style of uproarious festivity. Provoked enough we were as we slowly climbed the rocks back again to our camp, which we did not reach till midnight, and that in dismal and hungry plight.

The view over the valley of Cuesta and the neighbouring rugged mountain ranges, convinced us that it would be quite vain to follow the course of the Pecos any further with a view of discovering a suitable line for a railroad; and we therefore returned on the following morning to the main road, in order to follow the rest of our company through the pass of the Cañon Blanco.

We now had a broad, convenient road, leading between ranges of mountains, the feet of which, as well as the valleys, were shaded by lofty pines, while crippled species of the same tree had struck root in the clefts and chasms of the sandstone rocks, and blue-green cedars were seen rearing their stately crests on the loftiest points. Small treeless plains alternated with the pine-woods, and served as a home for thousands of prairie dogs, which, at the approach of our caravans, stuck out their little heads, and made their small voices heard through the woods; red and grey squirrels sprang merrily about on the grass, or fled from the unaccustomed disturbance to the highest trees, lying in 
ambush behind the boughs, though their bushy tails, blown about by the wind, betrayed their whereabouts; small partridges slipped with wet wings over the moss, and kites and eagles flew round low in the misty air. This mist, which had rendered the early morning dull, gradually thickened into a drizzling rain by the time we reached the spot where our main body had encamped - a spot easily recognisable by the smoking heaps of ashes, and the charred trunks of the pines; but though we immediately began a search for water, we were entirely unsuccessful, and concluded that the poor cattle had been obliged to do without the necessary refreshment, and go on their way athirst.

At this point the pass narrowed more and more, till precipitous walls of rock rose abruptly to a height of a thousand feet from the ground, showing varied, but mostly light-coloured, strata of sandstone.

The road, however, still remained as convenient as before, and the wheels rolled along easily on the firm ground, on which the falling rain had laid the dust. At noon the heavy clouds cleared off, and the sun shone out cheerfully over mountain and forest; but by the time we issued from the Cañon Blanco and overtook the last stragglers of our main body and the cattle, we became aware, as we could see far around, that a violent storm, which hid from us the prospect of the Gold Mountains, was driving swiftly towards us. The head of our procession had reached a small lake, where it was now proposed to encamp; and we hurried on, in order, if possible, to be under shelter of the tents before the storm came upon us, but we had not time; for, before we had finished drawing up the waggons into a circle, the hurricane broke loose, dashed the 
half-erected tents to the ground, and drove howling over us as the forerunner of the rain. All attempts to obtain protection from the weather were soon given up, and all we could do was to set our beasts at liberty, seat ourselves on our reversed saddles, throw our wrappers over our shoulders, and wait with patience. In a few minutes the place, as far as the eye could reach, resembled an agitated lake; and the water was up to our ankles, although the declivity of the ground favoured its running off quickly. By degrees the tempest abated, and the rain ceased, but an icy wind drove over the plain; and though it certainly dried the ground, it penetrated our drenched persons to the very marrow. The wood we had brought with us from the pass was, of course, under these circumstances, not easy to kindle; and even when we did, with much labour, bring it to a blaze, it was almost immediately burnt away by the strong blowing of the wind; so that the small stock we had could scarcely be made to serve for the cooking, and there could be no thought of drying and warming ourselves by it. All we could do was to get our tents pitched as soon as the marshy ground had gained sufficient firmness for the tent pegs to hold, and then to creep in among our blankets and buffalo skins.

The gale continued all night, so that in the morning the ground was dry enough for the heavily laden waggons to move on without sinking, and we prepared for an immediate departure.

Our company now again parted, Lieutenant Whipple turning northward to get to a road that also ran from the Cañon Blanco, and led in a north-westerly direction past the Gold Mountains to Galisteo and Santa Fé. 
The rough autumn had now come in earnest; a sharp wind drove heavy hail-showers before it; and though from time to time the sun broke through the rent clouds, the warmth of his beams was scarcely perceptible. It must be recollected that we were now at a height of 7000 feet above the sea-level; so that even in this latitude the cold was not surprising.

We proceeded on our way with all possible speed towards Galisteo, which, though thirty miles off, was appointed as the goal of this day's march; and as the distance to the town decreased, the blue masses of the Gold Mountains became darker, and their ravines and ridges discernable.

The soil here was rocky and barren; and since the grass was cropped off short, and the herds now withdrawn into more sheltered spots among the mountains, the country, in the absence both of cattle and vegetation, assumed a dreary aspect.

The sun had not yet set when our troop crossed the river Galisteo, and approached the first houses of the town of the same name.

Lying on the slope of a gently rising ground, it is prettily situated, and makes, from a distance, an agreeable impression, which, however, vanishes as soon as you enter its dirty streets, showing signs everywhere of extreme poverty, and find yourself regarded by every one you meet with mistrustful glances. Most of the male population, with their bearded faces and dirty blanket-wrappers, looked like banditti; and there was an impudent and profligate expression on the faces of the women, who greeted us besides with looks of mocking defiance.

We determined to pass the evening at a small inn, 
which looked somewhat more inviting than the other buildings, and entered an apartment that served at the same time as sitting, sleeping, and reception room, where we were welcomed by the host and his family, and some American officers then on their way to Santa Fé. Blankets were spread directly before the brightly blazing fire, we all lay down around it, and a lively conversation began. The officers had come from Albuquerque, where, according to their account, our Expedition was not yet expected. And we learned, too, that a small division belonging to our Expedition, which was to have come by the way of Texas, and joined us, had not yet arrived, as we expected it would have done; a delay that caused us some anxiety. As, however, it might have been considered unsafe for so small a party to travel alone across the steppes, it was thought possible that they might have been waiting to join some large party of commercial or military travellers.

Lieutenant Whipple's party, of course, asked a great many questions about Albuquerque, and the persons and things we were likely to come in contact with; and the questions were not only readily answered, but the answers accompanied by illustrative anecdotes.

"Old Fitzwater," began one of the officers, "whom you most likely know by name, has now been appointed by our government to be the Commandant for life of the military station of Albuquerque. This old soldier is about the greatest curiosity that you ever saw in your life. I believe he has not a bone in his body that has not been shot or hacked through, and patched together again, and his left leg is kept stiff by an iron rod, so that he has to mount his horse on the right side. Most of 
his wounds have been received in skirmishes with the Indians, but the severest in our war with Mexico. He was an old sergeant then, but could bear all the hardships and privations with the youngest man in the army. In some battle, I forget which, this old Fitzwater was posted with a party near a mass of rock, so that their rear was covered by a granite wall. He and his men kept up a brisk fire with their muskets upon the enemy's fusiliers, who answered to the best of their ability, and were occasionally supported by a whiff of grapeshot from their artillery. Just while Fitzwater was loading, a bullet went through the neck of the man next him with such force as to strike the granite rock behind and send the splinters flying out. One of these entered Fitzwater's left eye; but he only turned his bleeding face to his comrades, saying, 'Well, I never met with any thing like that before. I never believed a bullet, already past, could wound in the rebound! It's well it was not my right eye:' and he then proceeded to take aim at a Mexican. After the war he undertook regularly to escort the post from Texas to Santa Fé, and back again, and it was on these journeys that he so frequently met with hostile Indians. The astonishing coolness that he always displayed in moments of danger never once forsook him, and to these qualities he owes his present position in Albuquerque. His worst enemies were the Apache Indians, who were constantly following and endeavouring to get hold of him. One morning, when he was not far from El Paso, old Fitzwater was sitting by a fire preparing breakfast for himself and his only companion-a pretty substantial breakfast, too; for, however the old fellow has been cut and hacked about, his excellent appetite has never been 
injured. He was devoting himself with his whole soul to the cookery of a savory roast and the making of some capital coffee, when he suddenly saw himself surrounded by a party of Apache Indians, evidently with a hostile purpose. He saw in a moment the impossibility of resistance, for the very instant he had stretched out his hand to a weapon a tomahawk would have shattered his skull. He did not therefore take the slightest notice of the threatening gestures of the savages, but proceeded with his cookery, and carelessly told them to sit down and help themselves to some bits that were already done while he made some coffee and put some more meat to roast. This unaccountable coolness, united to the friendly invitation, so completely took the Indians by surprise, that they involuntarily obeyed, and squatted down to satisfy their appetites on Fitzwater's dainties, and afterwards went off without doing him any harm, or even touching any of his things. Fitzwater declares that, though he would much rather have given the Apaches a taste of his long knife than of his coffee and sugar, he was heartily glad to find himself and his companion with a whole skin after their visit."

The time flew so quickly with our talk, that the inhabitants, male and female, of the hacienda, had to remind us of the lateness of the hour, and this they did by unrolling their mattrasses upon the floor, and very composedly preparing themselves for their simple, but certainly not uncomfortable beds. We therefore took leave, wrapped ourselves in our blankets, and set out on our return to our tents. The wind had gone down-a clear frost had covered the standing waters with a thin crust of ice-the atmosphere was pure and 
transparent-and the stars sparkled in the firmament like millions of diamonds.

This fine night was followed by as beautiful an autumn morning as ever rose in New Mexico. As we took our departure from Galisteo, there was not a breath stirring; a heavenly calm seemed to brood over the mountain peaks and the hilly plain, and the warm rays of the sun found their way into every corner, and even among the dark boughs of the cedars. At the foot of the Gold Mountains the river Galisteo trickled through deep ravines, so that we had to desist from the attempt to follow its course, and describing a wide arch round the mountains, turn into the valley near the Rio Grande. For several hours the road was a continual ascent; but we then reached the highest point, after which it declined pretty rapidly to a valley, where, at the foot of an extinct volcano, there were some houses and gardens that seemed to invite us to rest.

During the last few days we had been much in want of water, but now we suddenly found ourselves in a region where springs as clear as crystal gushed forth from black rocks, and the choice of a camping-place depended only on the greater or less abundance of grass for pasture.

The presence of the many veins of water, that fertilise the fields and gardens, is probably connected with the action that has taken place in a near group of conical hills, which are unquestionably extinct volcanoes. Their craters have long ceased to smoke, and their scars have been covered by a thick coat of grass; but the sharp edges of the streams of lava that have flowed down their sides are still distinguishable. Similar volcanic phenomena are traceable on the eastern declivity of the 
Rocky Mountains near Santa Fé, and down the Pecos in the chain called the Raton Mountains. An isolated trachytic region of this kind is marked almost on the meridian of Tucumcari in the fine geognostic map of Marcou.

Many fine towns were built in both continents, in the immediate vicinity of active volcanoes, and they increased in population and prosperity, notwithstanding their frequent destruction by fire and ashes; on the ruins of the forefathers' dwellings arose those of new races, who, attracted by the sweet springs and fruitful valleys, forgot every danger, and transformed their environs into gardens of Paradise. The volcanoes of New Mexico are now, however, either dead or wrapped in a long deep slumber; and the settlers who have established themselves at their feet, enjoy the good gifts offered to them, without dreaming that they are resting on an ancient battle field of furiously contending elements, which are still carrying on their strife deep in the bowels of the earth-and that to this very strife they are indebted for the blessing that bursts forth for them from every rocky cleft and chasm. Long-horned oxen, fine woolled sheep and bearded goats, black-tailed deer and antelopes, drink with delight of these cool waters, and the grey bear, too, steps cautiously from the dark caverns of the neighbouring mountains to quench his thirst at the same all-bountiful springs. In the spot near one of these little settlements, where we proposed to encamp, juicy melons and rich, ripe grapes and peaches were to be had in abundance, so that we had a prospect of delicious refreshment as well as rest.

Since we had to reach the Rio Grande the following day, we were in motion again at an early hour; and fol. 
lowing a road that led over a rugged country, descended into a valley, where on the banks of a small stream tributary to the Galisteo, some Mexican settlements lay so close to one another, that they formed quite a town. We soon left the valley, and came to the stony bed of the Galisteo, which, inclosed as it is by high trap rocks, may be called a ravine. A considerable fall of the ground was here perceptible, for the little water there was in the river trickled rapidly over the smooth stones towards the Rio Grande. The waggons followed the windings of the stream, which were so short that we seemed to be continually in a rocky cauldron, and our view was extremely limited; but whether we looked back in the direction from which we had come, or forward to that we were going to, we had equally a magnificent scenic decoration before us, formed by the projecting and retiring masses of rock, which on both sides rise to a height of several hundred feet. Numerous squirrels were springing about among the loose stones, and the chapparal cock (Geococcyx Mexicanus) was hiding himself behind any projecting object he could find to escape the searching eyes of the hunters.

After a march of some hours in the Cañon Boca, as this ravine is called by the Mexicans, we found the left bank opening to a wide plain that extended to the spurs of the Placer, or Gold Mountains, and the lower valley of the Rio Grande, and across which various paths led to settlements. Before we had quitted the bed of the Galisteo we were able to distinguish the blue mountain masses that rise on the western shore of the Rio Grande, and mark the course of that river; whilst to the south the Sandra range joined those that bear the name Placer. As we left the Cañon Boca to turn into the 
better road along the plain, we came upon such wonderful formations of white sandstone, that we all involuntarily halted to gaze upon the spectacle. From out of the bed of the Galisteo rose a close range of elegant columns, growing shorter and thinner towards the end, and beautifully notched and ringed, which, at a short distance, had such an astonishing resemblance to the pipes of a mighty organ, that I believe we should have scarcely felt surprise to hear tones of solemn music issuing from them. But they lay there in majestic stillness, though the listening ear eaught various sounds of another kind. The stately buzzard, as he hovered on high, sent his piercing cry down to earth; the swallows twittered as they described, far below him, their zig-zag lines in the air; grasshoppers hung on the dry blades, and made as much noise in the world as they were able; merry crickets chirped from the cracks in the ground; and near the great silent organ, where an ancient tree bent down its decaying head, the woodpecker hammered away briskly, to the no small alarm of the less noisy inhabitants of the time-worn trunk. All these various tones blended into a chorus that sounded like a hymn of praise; and when other travellers stand still to admire the spectacle, and wonder at the results of a cause so simple as that of falling drops of water, to which it owes its origin, the devout Mexican bares his head, crosses himself, and kneels down to repeat an Ave Maria. 


\section{CHAP. XVII.}

THE VAlLEy OF THE RIO GRANDE DEL NORTE. - SAINT DOMINGO, AND THE PUEBLO INDIANS. - THEIR TRADITIONS. - DEPARTURE FROM SAINT DOMINGO. - ARRIVAL IN ALBUQUERQUE.

WHEN we had once obtained firm footing on the plain, we proceeded at a rapid trot. The valley of the Rio Grande was beckoning us, and every one was longing for the first sight of that much talked-of river and its banks. At length the way wound down a steep declivity of hard clay, and the Rio Grande lay in full view; but under what a different aspect from what we had anticipated! We had been dreaming, perhaps, of luxuriant vegetation-of lofty palms and giant ferns-of umbrageous groves and navigable waters: and now there stretched before us a treeless, clay-coloured flat, and a shallow, muddy river - a desert rather than a populous valley. At the foot of the hills the road turned towards the south, and the gloomy impression made on us by the first sight of this landscape became somewhat softened when we suddenly saw before us a peculiarly built town surrounded by fields and gardens.

This was Saint Domingo-an ancient settlement of the Pueblo Indians, which reminded us, at first, of the Casas Grandes on the Gila, and further south in Mexico.

Here, as in most of the towns of Mexico, unburnt brick was the chief building material, and it gave 
an old and ruinous aspect to the houses; which was increased by the various stories lying in terraces one over the other, so that part of the flat roof of the lower story served as a little court to the upper, and the highest was considerably the smallest. By this plan, as the houses are built close to one another, there are formed upper, as well as lower, streets, which lead past the doors of the dwellings on the second and third stories, and establish an immediate connection between them. There are no doors on the ground-floor; but the ascent from the street is by ladders, which can be drawn up when the security of the inhabitants is supposed to require it. An opening in the flat roof of the first story gives access to the interior, while other ladders lead from the platforms of the lower stories to the second and third.

The rooms on the ground-floor seem to be exclusively employed as store-rooms, sufficient light being afforded by small square openings, glazed with plates of transparent crystalline gypsum.

There is little life in the lower streets, but a great part of the population was assembled before the doors, the men smoking, the women working, the children at play; and all showed great excitement at our approach, and leaned eagerly over their parapets to look down on us as we passed. The noise that so peculiarly characterizes the towns and settlements of the whites was wanting here; there was no shouting, or bawling, or loud laughing, but the various groups conversed in low tones; and half-veiled figures, bearing on their heads party-coloured earthen vessels, hastened with light steps through the streets, or nimbly ascended the broad rungs of the ladders without even putting a hand 
to their burden, and without spilling the smallest fraction of its contents.

In the meantime we had reached an open quadrangular square, two sides of which were formed by houses, and the remaining ones by the church and other public buildings; but we did not then take much time to look about us, but followed an Indian, who led us to a green meadow beyond the town, where we pitched our tents as quickly as possible, in order to get back the sooner to the town. The entire population of Saint Domingo did not consist of more than eight hundred persons; and since the masculine part of it at least was familiar with Spanish, it was easy, when they came flocking out to the camp, to enter into conversation with them.

Our first inquiry, of course, was for the Alcalde of the town; and the reply, given with a somewhat offended air, was, that there was certainly a Gobernador, but no Alcalde, at Saint Domingo. But Lieutenant Whipple found means to make amends for the wound unintentionally given to the vanity of the good folks, by requesting the honour of the Gobernador José Antonio Herrera's company to supper in his tent. A complaisant Indian immediately undertook to be the bearer of the invitation, and soon reappeared with the Gobernador himself, a stately-looking Indian, followed by a suite whom he treated, very loftily, as his subjects. He received a warm welcome, and the camp was soon in a considerable bustle, our visitors inspecting every thing with the most lively curiosity, but, unlike most Indians, refraining from the smallest freedom, or attempt to appropriate what belonged to others. They were handsome, well-formed men, who, notwithstanding the decided Indian cast of their features, were rather prepossessing 
to the great satisfaction of the good-natured host, not only done ample justice to the viands set before us, but put the remainder into our pockets, as well as satisfied our curiosity by a minute examination of all the objects lying or hanging round, we bade "Good night" to our Indian friends, and continued our exploring expedition along the roofs of the lower stories. We entered many dwellings, found everywhere the same domestic arrangements, and were received with the same obliging hospitality; and at a late hour we returned to our temporary homes on the green meadow.

Early on the following morning we visited the town again, especially to see the interior of the church; for which the Gobernador had given us the permission, and the key, besides offering us his company.

The church was not externally distinguished from most others in the smaller Mexican towns; it had rough walls inclosing a simple hall, and the chief gable was turned towards the square, and projecting a little, was supported by two square clay columns. Between these two was the entrance, and over it a gallery communicating with the choir. On the roof was a kind of stone scaffolding, or belfry, containing the small bell, and surmounted by a cross. Some subordinate buildings in the same style, and an inclosed churchyard, completed the Pueblo church, which evidently owes its origin to Catholic missionaries. The interior was in the same style; there was a kind of altar; and the walls were of smooth clay, on which hung some old Spanish pictures, - the sole decoration, with the exception of some rude Indian paintings, amongst which we remarked the figure of a man on horseback riding over a troop of men: a Conquestador, therefore, and evidently an allu- 


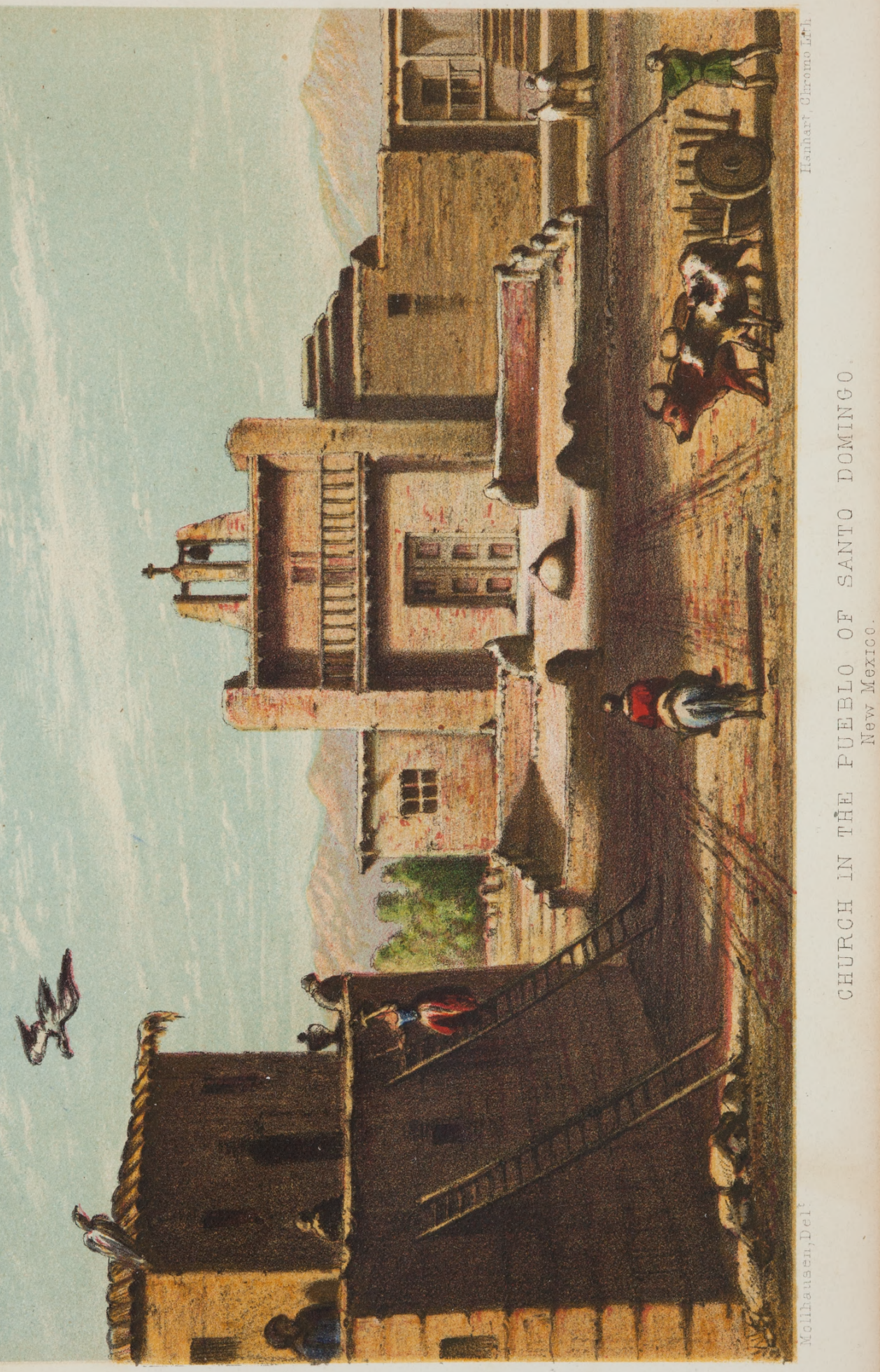



sion to the Spanish conquest. The Catholic and Aztec religions were evidently blended in these representations; the Holy Virgin is often found in company with an Indian figure denominated Montezuma by the ignorant people of northern Mexico, and under the cross is seen a picture of the caves where the sacred fire was kept burning. In the populous Indian towns on the Rio Grande, and westward of the Rocky Mountains, this "everlasting" fire has long been extinguished; but it appears from tradition (a very uncertain authority, of course), that the holy flame was last cherished near the sources of the Pecos, where ancient ruins still attract the traveller's attention. It is also stated that Montezuma planted a young tree on this spot, and declared that as long as it stood, the descendants of the Aztecs, the present Pueblo-Indians, should form an independent nation; but that when the tree had disappeared, white men should come from the east and overrun their country. The inhabitants of the Pueblos were then to live in peace with these white men, and patiently await the time when Montezuma shall return and unite them again into one powerful race. With these dark, vague traditions, an Indian of Santo Domingo entertained us as we walked through the town; but time flew fast, and we could only spare enough to peep through the little windows of the lower stories and see the women at work shelling beans, or grinding maize between two stones, and keeping time with their work to songs or the beating of a drum. We went up ladders, though, to the highest roofs of some of the houses, to choose a handsome specimen of deer's antlers from the stock kept there.

When we had taken leave of the friendly Indians, we made haste to mount and ride over the sandy plain to VOL. I. 
overtake the waggons, which had now got a considerable start. Early as it was, we met some industrious people driving laden asses, or small carts drawn by oxen, who moved with great deliberation, while their masters walked behind with long whips, and we looked back from a rising ground once more on Santo Domingo, which lay like a heap of grey ruins among its vineyards and orchards, now coloured with autumnal tints.

After a ride of six miles we found ourselves opposite the little Pueblo of San Felipe, situated on the right bank of the Rio Grande. It lies on a plain inclosed by naked rocks, and has any thing but a pleasant aspect. Immediately after this we crossed the river Tuerto near its mouth, passed through the Mexican town of Algodones, and went on along the foot of the Sandia range, between which extensive chain and the Rio Grande we kept about midway.

The road led us sometimes across great tracts of sandy, barren soil, where no animal is to be found but the prairie dog and lizards of many kinds, and sometimes past extensive fields of maize and beans.

The neighbourhood of settlements and cultivated lands was recognisable long before by the canals and ditches which intersected the low lands in all directions, and were destined to convey the water of the Rio Grande to the plants and seeds; for without such measures it would be scarcely possible to raise the most scanty harvests under the arid climate of New Mexico. Flocks of marsh and water birds animate the fields thus irrigated; and under shelter of the close stalks of the Indian corn some of the sportsmen got a few very effective shots among them. This part of our journey was quite like a pleasure tour, and so much the more so 
as thriving settlements and pretty ranchos continually lay smiling before us. We could have been only a short day's journey from Albuquerque when we determined to pass the night in the neighbourhood of Bernalillo, also an Indian town, and to wait for morning to continue our journey.

Twilight was still resting on the valley of the Rio Grande, though the peak of the Sandia range had begun to glow in the morning sunshine, when the impatient company was already in the saddle, and urging on the cattle to all possible haste. The environs had now lost all their interest for us, and all eyes were looking out for the distant church towers of Albuquerque.

Every passer by, whether Indian or Mexican, was asked about the distance to the place, and the usual answer was, Quien sabe, with which we had, perforce, to be content.

We had come so far, that we found ourselves opposite the southern point of the Sandia mountains when our way was crossed by a broad road, which, coming from the east, led to an apparently great settlement on the Rio Grande. Here some Mexican women, whom we saw at work, were again questioned concerning the town of Albuquerque, and they laughingly pointed to the river, where a row of low houses and two small towers indicated the presence of a town. We turned immediately into the cross-road; the horsemen spurred on, the waggons followed briskly, and we soon found ourselves between fences and long buildings, from the doors and windows of which looked out men wearing the uniform of the United States dragoons.

Passing these buildings, we went on to a green sward beyond the town, with white tents gleaming from it, 
and there checked our mules, and received a hearty welcome. There was as much hand shaking, and eager questioning, and talking amongst us, as if we and our comrades of the Expedition had been separated for three years instead of three days; and suddenly, by some enchantment, bottles and jugs, filled with the excellent wine of El-Paso, made their appearance, and our joyful reunion was celebrated by a festive banquet in the open air. After the first burst of our jollity was over, we hurried into the town to get our letters that had been forwarded to us by the government in Washington through the Santa Fé Post to Albuquerque; and in the evening many of us might have been seen in our tents reading over, for the third or fourth time, the news from our distant homes.

In a few days we read the following announcement in the Amigo del Pais, the weekly paper of Albuquerque :-

"Projected Railroad from Albuquerque to the Pacific.

"We have had the pleasure of welcoming in our town the Railroad Expedition under command of Lieutenant Whipple, which arrived here safely on the 3rd October, 1853. The expedition consists of the following members:- Lieutenant Ives, First Assistant of Lieutenant Whipple in the Topographical Department; Dr. John M. Bigelow, Physician and Botanist; Jules Marcou, Geologist and Mineralogist; H. B. Möllhausen, Naturalist and Topographical Draughtsman; C. B. Kennerley, Naturalist; Albert Campbell, Engineer and Surveyor; Hugh Campbell, Astronomer; W. White, Meteorologist; George Garner, Astronomer and Secretary; John Pitts Sherwood, Meteorologist; Thomas 
Park, Astronomer; Lieutenant Johns, 7th Infantry Regiment, Commander of the Escort; D. S. Stanley, Quartermaster and Commissary.

"We have received from Lieutenant Whipple the most satisfactory intelligence concerning the route examined by the Expedition. From Memphis on the Mississippi, to Fort Napoleon at the mouth of the Arkansas, and up this river to Fort Smith, it travelled with all possible haste; and from the last-named point the real labours of the Expedition began. From Fort Smith the party passed through the lands of the Choctaw Indians, followed the valley of the Canadian to its great bend, then cutting off this circuit, touched on the tributaries of the Washita, and after some days came again to the Canadian, whose valley they followed for another 150 miles. Leaving this river, they then proceeded to the highlands of the Llanos Estacados, crossed a small portion of it, and travelled along the water-shed between the Canadian and the Pecos, and then crossing the Pecos, reached Anton Chico, where the Expedition divided into two parties; Mr. Albert Campbell proceeding with the main body, viâ Laguna, and passing south of the Sandia Mountains; whilst Lieutenant Whipple went round to the north of the range, by Galisteo and Santo Domingo, to the Rio Grande. At the eastern part of the route lie immense forests of timber, admirably adapted to the construction of railroads, and in such quantity, that the whole length of the line might be thence supplied. There is also excellent wood to be found in the mountains near Anton Chico, inexhaustible beds of coal in the State of Arkansas, and on both sides of the Rio Grande fuel for all eternity. On the whole route no real obstacles have been met with, and the 
Expedition has very seldom been a night without water. A bridge over the Rio Grande might be built almost at any part with little difficulty; but the most suitable points appear to be San Felipe, thirty miles above Albuquerque, and Isleta, sixteen miles to the south of that point."

So far, then, our appointed task of exploring the country between the 35 th and 36th parallels of north latitude had been performed; but there remained for our investigation the entirely unknown regions westward of Zuñi to the coasts of the Pacific. This, as we were informed, was likely to be the most troublesome part of our undertaking; and as a protection against hostile Indians, an additional military escort of twentyfive men, under the command of Lieutenant Fitzball, was ordered to join us at Fort Defiance. The winter was now at hand, and must unavoidably add much to the difficulties we should have to contend with; but we enjoyed some days of most welcome rest, and exchanged reciprocal good wishes for a safe and speedy arrival at our ultimate destination, the Mission of Pueblo de los Angelos on the Pacific Ocean. 


\section{N 0 T E S}

To

THE FIRST VOLUME.

\section{Geological Structure of the Country.}

Page 8.-Westward of the Mississippi, and before coming to the Rocky Mountains, we find in the plains and prairies of the southern region, five distinct groups of rocks, at a considerable distance from one another, and consisting of granite quartz, and indurated talc (Schistes talqueux). These masses have nothing in common with the Ozark Mountains, and although three of them lie in the same region, they cross the lines of displacement (lignes de brisements) of that mountain system. The most northerly of these masses is found in the south-western part of the State of Missouri, near Potosi, and Perryville, where a part of it is known under the name of Iron Mount. Three of these groups lie also on a line running from east to west; the first, in the neighbourhood of Little Rock, stretches to Hot Spring, and Sulphur Spring, in the State of Arkansas; the second, of smaller extent, lies in the country of the Chichasan Indians, eastward of Fort Washita; finally, the third, which is the most considerable, both for extent and elevation (some peaks rising to a height of 3000 feet), is known under the name of the Witchita Mountains. This latter range occupies the country between the northern arm of the Red and the False Washita rivers, and serves as a boundary to the Choctaw and Comanche Indians, and rising in the middle of the prairie, it forms a striking landmark for travellers crossing this desolate region. The fourth of the granite masses, and the most southerly, was laid down by Mr. Ferdinand 
Roemer, who came on it in Texas, between the rivers Llano and San Saba, not far from Fredericksburg.-(Jules Marcou, Résumé Explicatif d'une Carte geologique des États Unis, p. 107. All remarks of M. Jules Marcou, concerning the geological formation of the territory described in these volumes, will be found also in the Report of Captain Whipple, as M. Marcou accompanied the Expedition as geologist.)

\section{Coal Beds on Mont Petit Jean.}

Page 9.-Dr. Shumard, in Fort Smith, has pointed out and described the carboniferous limestone (Calcaire carbonifêre) in the county of Washington, in the State of Arkansas. It is a blue, or dark grey limestone, containing a great number of fossils, which all characterise the lower coal formation of the Mississippi valley, a formation that will probably be found at several points of the Arkansas. I have myself seen it at Shawnee Town, in the western prairies, where it forms Delaware Mount, rising on the right bank of the Canadian. The fossils that I collected on the Delaware Mountains are, first a new kind (ein neuer productus), represented by Mr. Hall in the Report of Captain Stansbury, under the false name of Orthis umbraculum; then a real orthis, also new, and with numerous stems of crinoidia (Tiges des Crinoides.) - (Marcou, Résumé, p. 39. Randolph B. Marcy, Report of the Red River of Louisiana, Append. D. page 166 and 179.)

\section{Far West Coal Field.}

Page 43.-Finally, we find in the west an immeasurable bed of coal, stretching without any interruption, from above the Monte Forts (Tower) to Fort Belknap and the Rio Colorado, in Texas. This vast bed has only been examined with care in a very few places, and all that is known with certainty of it is its extent, continuity, and boundaries, from the observations made in different parts by $\mathrm{Mr}$. Nicolet, Dr. D. Owen, Dr. H. Kay, Dr. Shumard and myself. The upper coal formation of the basin westward of the Mississippi, known as the "Far West Coal Field," comprises two great divisions, the lower consisting of black marly slate and beds of coal, and the upper formed in regular strata with thick beds of red sandstone, in 
which some remains of fossil plants are still to be found. The beds of coal are here less numerous than in the coal basin of the Gulf of St. Lawrence, and there are not more than five or six that can be worked with advantage. Besides the coal, iron ore is found in superfluity in the lower division of the coal formation, particularly in the States of Arkansas and Texas, and there are some accumulations of gypsum. The district of the upper carboniferous limestone (Carbonifêre supérieur) of these regions, does not exceed the thickness of two or three thousand feet.-(Marcou, p. 49. Marcy, Append. D. p. 166.)

\section{Comet of 1853.}

Page 98. - This comet, perfectly visible to the naked eye, was first seen on the evening of the 18th of August, 1853, by our astronomer's in the camp of the Black Beaver, and observed every following evening for a long time. A letter concerning it, addressed to Baron Alexander Von Humboldt, by Mr. Adjunct Bruhns, gives the following information: "This comet is the same that was seen by Dr. Klinkerfues, at Grottingen, on the 10th of June, 1853 ; the path of which was calculated from three observations made here, and whose visibility to the naked eye was foretold in the Astronomical News (Nos. 864-869, vols. 36-37). It is the great comet of which Julius Schmidt, under his Olmütz sky, got such excellent day observations (when it was about $10^{\circ}$ from the sun). I myself first saw it here with the naked eye on the 8th of August, and it was particularly bright towards the end of August and the beginning of September, when it reached its perihelion. It appeared in the western sky several evenings with a tail stretching over five degrees, and from more favourable points in the south of Europe, this tail appeared as much as $12^{\circ}$ in length. In the southern hemisphere, and especially at the Cape of Good Hope, it was seen with the telescope till the beginning of January, 1854."

\section{Stratification of Rocks in the Coal District.}

Page 106. - There is found on the beds of the coal district a series of stratified rocks, consisting chiefly of sandstone and red clay, attaining a thickness of five or six thousand feet. In consequence 
of their position between the coal and the Jura formation, they belong to the epoch of the new red sandstone. I have shown the super position and correspondence of the strata between the coal and the new red sandstone, in Tegeras, Antonitto, and San Pedro, as well as in the Sierra de Sandia (Rocky Mountains), in Pueblo de Pecos and at Santa Fé, on the two river territories of the Sierra Madre, at Aqua Fria, as well as at various points of the spurs of the Sierra de Mogoyon; and finally, I have ascertained very clearly that on the whole western declivity of the Delaware Mountains, up the Topofki Creek, on the shores of the Canadian, the beds of new sandstone of the Perm formation, do not agree in their stratification with that of the lower coal formation, or mountain limestone, which before the formation of the new red sandstone, has been violently dislocated and upheaved. The new red American sandstone falls into four steppes (étages) or terraces, at least in the places where I have observed it.

The first or lowest, consists of a magnesian or dolomitic limestone, which lies in very regular beds of from four inches to a foot thick. Many of these strata enclose a considerable number of fossils, all in very bad preservation, and firmly united with the rock; but I could, nevertheless, recognise a Nautilus pteroceras, and stems of Encrinites. This formation has, by its strategraphic position, much resemblance to our Zechstein, the upper portion of the Perm system, and with the magnesian limestone of England. I have met with it only between the Rio Colorado Chiquito and the Sierra Blanca or Mogoyon, as well as in a promontory of this Sierra, in a breadth of five or six miles, and in a thickness of about 1000 feet.

The second steppe is formed, first of clay, blue and red at the base, but in which the red becomes predominant as you ascend in the mass, until it assumes a cinnamon colour; then of red sandstone with green spots, somewhat friable, in firm, or slate-like layers, traversed by clay, which it ultimately replaces; but in the latter case, the red sandstone is also friable. More frequently it is finely granulated, whilst in some beds, in various regions, the grains are coarse, and at length pass into real conglomerate. In this terrace, which attains an average height of from two to three thousand feet, no fossils are found. The ease with which the red sandstone decays under the influence of the atmosphere, is the cause of the phenomena, so frequent in these regions, of immense separate blocks, which assume the form of gigantic cones, of pillars, of architectural 
ruins, \&c. The environs of Rock Mary, on the right bank of the Canadian, offer many examples of this. This second terrace covers a great extent of the Western prairie, especially at the boundaries of the great coal basin of the Far West. In following the thirty-fifth parallel of north latitude, I found that it formed the entire region from Topofki Creek to Rock Mary, and that it appeared at various points of the Rocky Mountains, of the Sierra Madre, and the shores of the Rio Colorado Chiquito._- (Marcou, Résumé, p. 55.)

\section{Cross Timbers.}

Page 137.-For further information on the Cross Timbers, see Marcy, Report, p. 34 .

\section{Vast Beds of Gypsum.}

Page 154. - The third terrace consists principally of strata of red argillaceous earth, or clay, which often inclose immeasurable accumulations of white gypsum, irregularly intersected with veins of selenite, and with beds of dolomite or magnesian limestone intervening, and frequently beds of rock salt or saline clay between the layers of gypsum. The average height of the strata of this third terrace, is about fifteen hundred feet, fossils are scarce in them, and mostly limited to fragments of petrified wood. In one of the small tributaries of the False Washita, near the Antelope Hills, I found a real petrified tree, in which the branches attached to the trunk were still preserved, and sections of which, when polished, showed the greatest resemblance to those of the Pinites fleuratii (?), which Dr. Mougeot has described as occurring in the new red sandstone of the valley of Ayol in the Vosges. In my route along the thirtyfifth parallel north latitude, I was constantly on this terrace, from the neighbourhood of Rock Mary to the Arroyo Bonito, or Shady Creek, and twenty leagues of it were entirely occupied by gypsum. Dr. G. Shumard, in his investigations in connection with the Expedition of Captain Marcy, to examine the sources of the Red River of Louisiana, crossed this bed of gypsum, from the western declivities of the Witchita Mountains, to the foot of the Llano Estacado, and found that it had a breadth of forty leagues. Further Captain Pope, in his exploring journey from El Paso to Preston, found these 
beds of gypsum at the sources of the Rio Colorado of Texas, and on the Rio Brazos. It is known that gypsum exists on the Arkansas, near the place where the road followed by the traders between Santa Fé and Independence touches on the river, so that it appears there is in the great prairies of the West, a bed of gypsum, extending from the thirty-second to thirty-eighth degree north latitude, and of a breadth varying from fifteen to forty leagues, and it will probably be found that it really extends to the north beyond the thirty-eighth parallel.

This terrace covers, as I have said, a great part of the prairies, and it is again found, with a magnificent development of gypsum and dolomite, in the Rocky Mountains, at San Antonio, Pecos, in the salt pits of Grand Quavira, Pueblo de Laguna, then at the Pueblo Creek, not far from El Paso, and in the Sierras de Jemez, de San Juan, and Madre.

Westward of Züni, the terrace is not so massive as in other regions ; after this the gypsum is found in very inconsiderable quantities, and at last fails altogether. -(Marcou, Résumé, p. 57.)

\section{Gypsum Region.}

Page 156. - This gypsum region is described in detail by Marcy. -(Exploration, Report, pp. 168, 172, 174.)

\section{The Upper Terrace.}

Page 228. - The upper or fourth terrace falls into two principal groups. The lower is formed by thick beds of whitish grey sandstone, but which sometimes assume a red or rose-colour tint. The upper group consists of beds of calcareous sandy clay (d'assises d'argile calcareo-sableuse), which show streaks of very bright colours, violet, red, yellow, and white. This fourth terrace shows a striking resemblance to the Marnes irisées of France, the Keuper of Germany, or the variegated marls of England, with the exception of the amaranth yellow colour which I have never seen in Europe. But for this I might have fancied that instead of being in the wildernesses of the Rocky Mountains and the prairies, I was at some point of the Jura, or the Neckar valley in Swabia.

The sandstone of this terrace is very much developed, very firm, and rather indistinctly stratified; it is 1000 feet thick, while that of the German Keuper, or the French Marnes irisées, is not more than 500 ; and this gives on the whole 1500 feet for the upper steppe 
or terrace of the new red American sandstone. The variegated marl being a rock of no great firmness, has in many places disappeared, from the effects of denudation, and can in general only be discovered where it has been protected by the Jura formation. The masses of sandstone, on the contrary, have offered great resistance, and the rock is found on extensive surfaces, and often assuming the most whimsical forms, which have been compared to ruins of temples, natural fortresses, giants' tombs, \&c. Along the thirty-fifth parallel north latitude, this sandstone covers all the heights of the plateaus or mesas, on the right and left bank of the Canadian, from the Antelope Hills to the Llano Estacado, of which it forms the foot; and it afterwards extends along the bottom of the valleys of Rocky Dell Creek and Plaza Larga, to Anton Chico, and Cañon Blanca in New Mexico.-(Marcou, Résumé, p. 58.)

\section{Ascent to the Llano Estacado.}

Page 240. - A scarcely perceptible slope leads from the prairies to the foot of the Llano, and then follows a steep ascent, varying in height from 300 to 450 feet, to the summit of the plateau. During the ascent you perceive that the red and variegated rocks that have presented themselves for many days in succession in the journey through the prairies, have given place to others of different colour and structure, and that the strata of the new red sandstone which you thought you would never get to the end of, is covered by layers of a newer formation, that lie regularly stratified on the fourth terrace.

I shall describe the Jurassic formation of the Llano Estacado, as it appeared to my own observation, referring to the notices of it that I find in my journal.

In September 1853, I was on the Llano Estacado, at a spot on the road from Fort Smith to Santa Fé, known under the name of Encampment Creek, and this is the section which I observed on the left bank of the stream.

First comes the Keuper or variegated marl (Marnes irisées), which forms the bottom of the brook and rises to the middle of the ravine. Then comes a calcareous sandstone (Calcareo-sableux) of a yellowish colour, resting upon the new red sandstone, and containing numerous cretaccous formations of the size of a hazel nut, in a stratum thirty 
feet thick; and this is followed by a layer of conglomerate with a very hard calcareous cement of a rose tint, and about two feet in thickness. Then comes a bed of white, very hard limestone, with shelly fracture, and finally a rather grey or white limestone, brittle, half oolitic, partly calcareous, and having many analogies with the coralline oolithus in the environs of Porrentray. This last limestone, the stratum of which is fifteen or twenty feet thick, covers the Llano and forms in its disintegration the vegetable soil, for on this lofty plateau, there are no traces of alluvium. I found no fossils at all in the formations at Encampment Creek, for which reason I can draw no conclusions as to its relative age, further than that it is much newer than the American Keuper.

After we had traversed the Plaza Larga, which is entirely formed of sandstone and red argillaceous earth, we reached the foot of the mountain that from its shape we named Pyramid Mount.

The northern side of it has sunk perpendicularly, and all the strata of which it is composed are so completely laid bare, that no better geological section could be wished. The steep cliff where the layers are exposed is 500 feet high, and its structure is as follows:

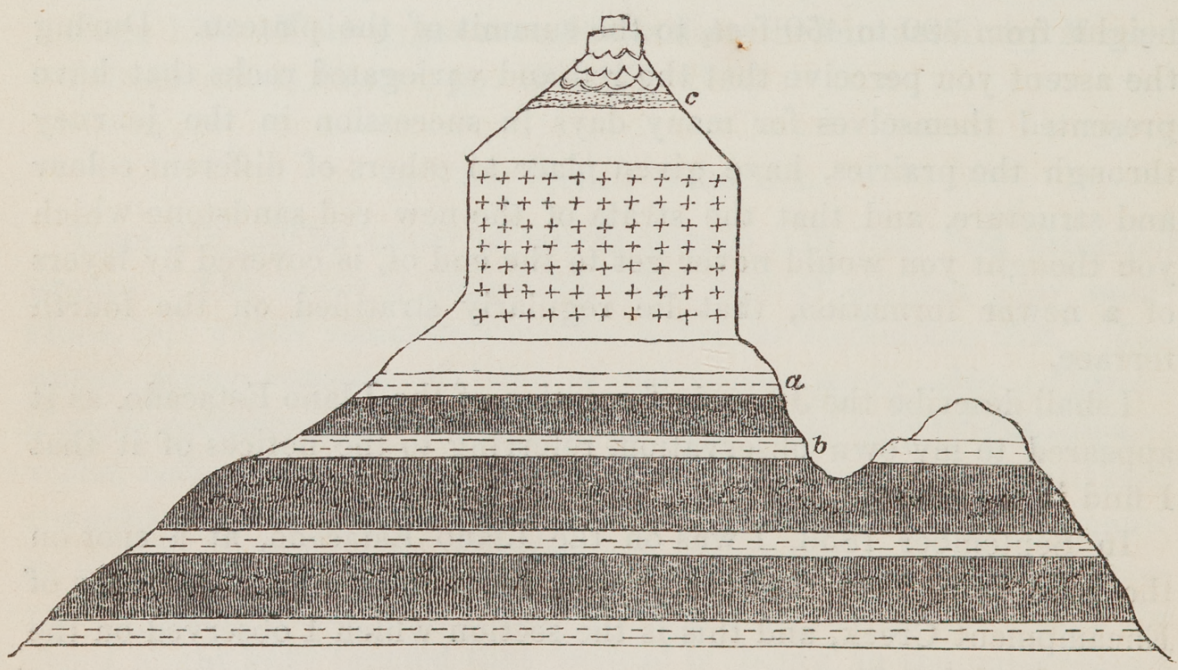

a. Bed of variegated marls in contact with the Jurassic formation.

b. Alternations of calcareo-argillaceous marls of various colours.

c. Strata containing Gryphaa dilatata, and Ostrea Marshii.

From the base to about half the height, the first 200 feet consist of strata of variegated marl, in red, green, and white stripes, and 
resembling in their aspect those in the stone quarries of Boisset near Salino. A layer of bluish grey clay, a foot thick, is next to the new red sandstone, and is in immediate contact with a white finely granulated sandstone eight feet thick, and belonging to a newer formation, the age of which $I$ have endeavoured to determine. Above this is an immense stratum eighty feet thick, of very hard and finely granulated sandstone of a light yellow colour, split as perpendicularly as a wall. On this are deposited beds of white sandstone, which are thin, by no means hard, and much affected by the atmosphere, and at the foot of each stratum is found a layer of sand formed from its disintegration, the united thickness of which is twenty-five feet. Then comes a thirty feet deposit of blue clay tinged with grey, and of slate-like structure, and in which, six inches from the white sandstone, I found the bed of Gryphæa, crushed, and almost unrecognisable as I met with them the preceding day in the bed of the rivulet. The specimens of Gryphæa that I collected in climbing the height, surprised me by their form, which nearly resembles that of the Gryphace dilatata of Oxford, and the Vaches noires of Normandy. Subsequently, I found in the same bed with the Gryphæa, a shell of the Ostrea Marshii in remarkably fine preservation.

This discovery of pure fossils put an end to all doubt concerning the age of the Llano Estacado, and assured me that I had met with the true Jurassic formation in North America - but to go on with the section of the Pyramid Mount. Over the blue Oxford marl are beds of sandy limestone of a dark yellow colour, very hard, and with a shining and reflecting fracture (miroitant), as in the yellow limestone of the lower oolitic rocks of the Jura. Each of these beds is five or six feet thick, and they extend to the summit of the mountain, where the upper stratum consists of a flint-like, white, and very firm limestone. The entire upper portion of the enormous Llano Estacado consists therefore of Jurassic formation, with the exception of two vast deposits mentioned by Mr. Kendal in his work entitled "Narrative of the Texan and Santa Fé Expedition." In the north of the Llano Estacado, the summits of the separate conical hills consist of it; as for instance, those of the great and little Tucumcari, - real prolongations of the Llano Estacado, - which extend between the rivers Canadian, Cimaron, Purgatoire, and Upper Arkansas. (Marcou, pp. 63-65.) 


\section{Gold Mountains.}

Page 316. - In the mountains of the Old Placer and of the New Placer, near Santa Fé, in New Mexico, are quartz veins that contain gold in sufficient quantity to pay for the working.-(Marcou, p. 111.)

\section{The Volcano Cerrito.}

Page 328. - The first volcano I met with in my researches in the Rocky Mountains lies between Galisteo and Peña Blanca. It bears the name of Cerrito, and extends into the valley of the Rio Grande del Norte, forming a kind of link between the Sierras of Santa Fé, de Jemez, de Sandia, and the Placers. This old volcano is not very lofty, and the various cones of which it is formed do not rise higher than from 800 to 1000 feet above the plateau from which it arises. Its streams of lava have spread over all the regions between Galisteo, Creneguilla, Naule, and the Pueblos of Cochito and San Felipe; and the Rancho of Cerrito lies in the very middle of the crater. The Rio Grande and the Rio Bajado, or Creneguilla, have worn their present channels in the lava of the volcano, and on the sections brought to light by cutting it is seen that the streams of basaltic lava have again covered the drift, and in many places have even transformed it into marble (brèche) or volcanic conglomerate. - (Marcou, pp. 113-115.)

In addition to M. Marcou, the following gentlemen have done much for the knowledge of the geography and geology of New Mexico:- MM. Emory, Wislizenus, and Bartlett; Drs. French and Marcy, and Captain Sitgreaves.

\section{The Sandia Chain.}

Page 341. - The Sandia Chain is an easterly range of the Rocky Mountains. - (Marcou, p. 5.)

END OF THE FIRST VOLUME. 





$$
\begin{aligned}
& 508.7 \\
& 11726
\end{aligned}
$$




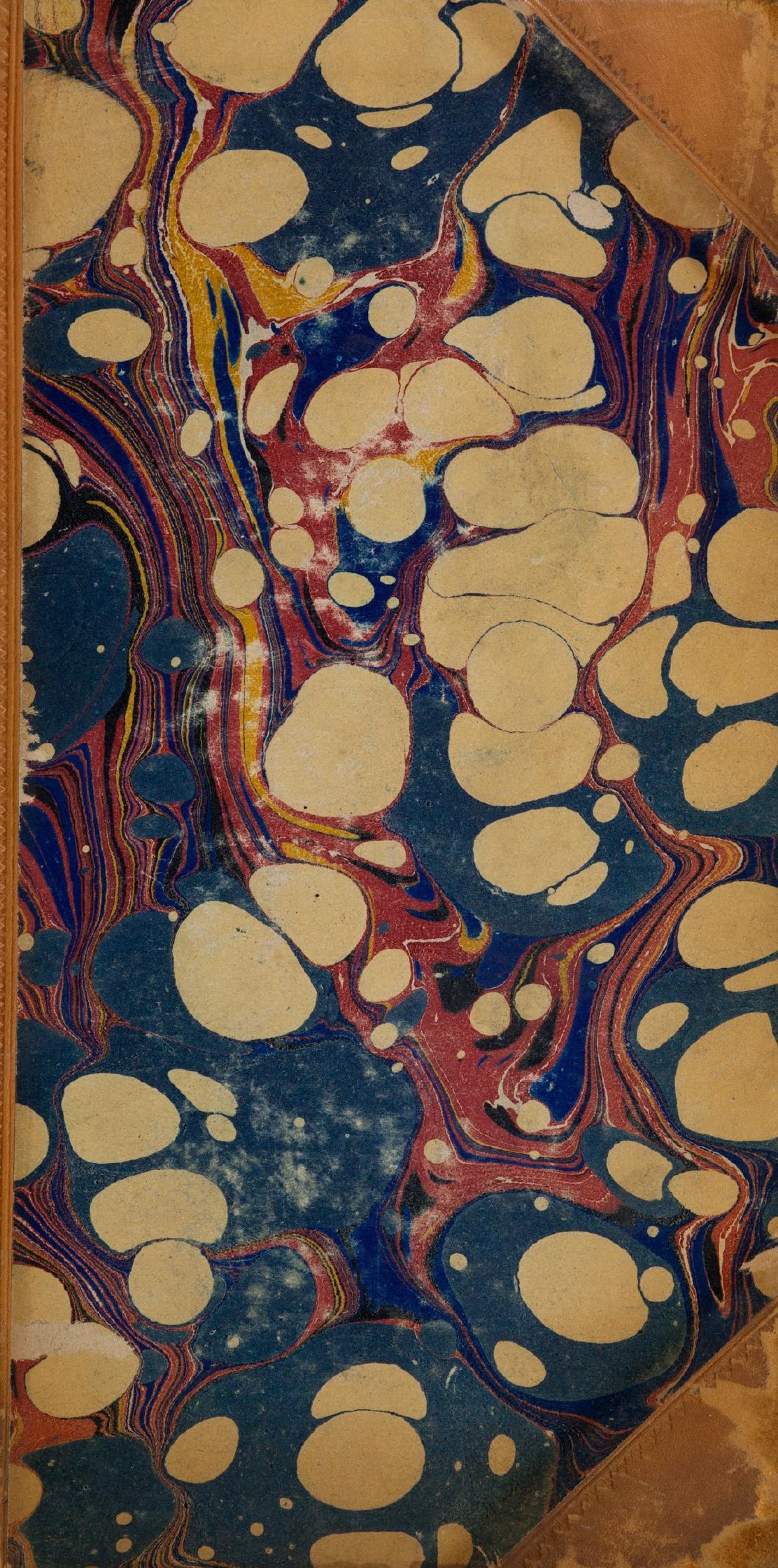

